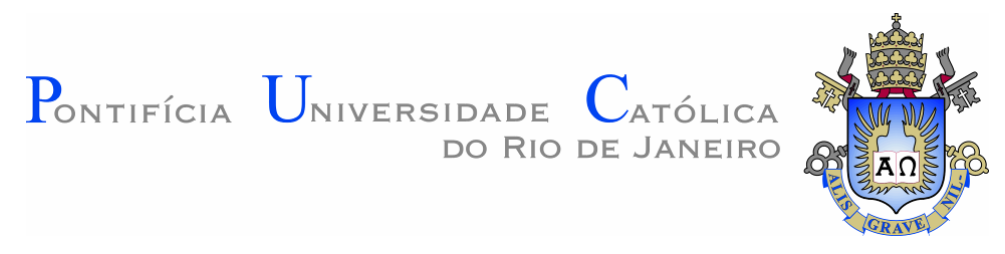

Claudia Habib Kayat

\title{
Inovação em Design de Embalagem, por meio da \\ Biomimética e das novas tecnologias digitais
}

Dissertação de Mestrado

Dissertação apresentada ao Programa de Pós-graduação em Design da PUCRio como requisito parcial para obtenção do grau de Mestre em Design.

Orientador: Prof. Claudio Freitas de Magalhães

Rio de Janeiro

Dezembro de 2015 


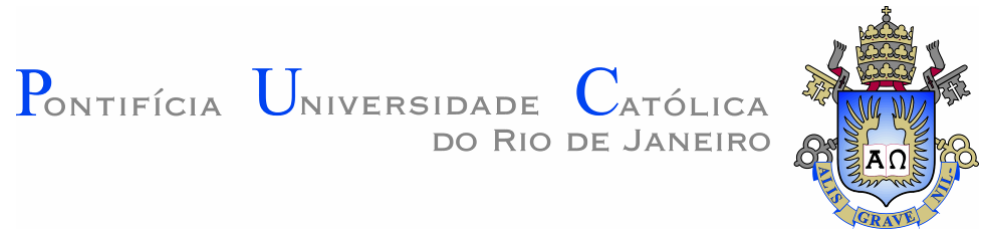

Claudia Habib Kayat

\section{Inovação em Design de Embalagem, por meio da Biomimética e das novas tecnologias digitais}

Dissertação apresentada ao Programa de Pós-graduação em Design da PUCRio como requisito parcial para obtenção do grau de Mestre em Design. Aprovada pela Comissão Examinadora abaixo assinada.

Prof. Claudio Freitas de Magalhães

Orientador

Departamento de Artes \& Design - PUC-Rio

Prof. Jorge Roberto Lopes dos Santos Departamento de Artes \& Design - PUC-Rio

Prof. Domingos Manfredi Naveiro Instituto Nacional de Tecnologia - INT

Profa. Denise Berruezo Portinari Coordenadora Setorial do Centro de Teologia e Ciências Humanas - PUC-Rio

Rio de Janeiro, 18 de Dezembro de 2015. 
Todos os direitos reservados. É proibida a reprodução total ou parcial do trabalho sem a autorização da universidade, da autora e do orientador.

\section{Claudia Habib Kayat}

Graduou-se em Design Industrial pela Pontifícia Universidade Católica do Rio de Janeiro (1987). Cursou Packaging Engieneering no Japan Packaging Institute, Tóquio, 1993. Com 32 anos de prática profissional, acumula uma extensa experiência nas áreas de Design de Produto, Embalagens e Branding, tendo realizado diversos projetos para empresas, tanto no Brasil quanto no exterior. Atualmente é professora na graduação do Departamento de Artes e Design da PUC-Rio e sócia-diretora da empresa HOK Inovação, onde dirige os Programas de Inovação.

Ficha Catalográfica

Kayat, Claudia Habib

Inovação em design de embalagem, por meio da biomimética e das novas tecnologias digitais / Claudia Habib Kayat; orientador: Claudio Freitas de Magalhães. - 2015.

150 f. : il. color. ; $30 \mathrm{~cm}$

Dissertação (mestrado)-Pontifícia Universidade Católica do Rio de Janeiro, Departamento de Artes e Design, 2015.

Inclui referências bibliográficas

1. Artes e design - Teses. 2. Embalagens. 3. Alimentos. 4. Biomimética. 5. Novas tecnologias (microtomografia, impressão 3D). 6. Inovação. I. Magalhães, Claudio Freitas. II. Pontifícia Universidade Católica do Rio de Janeiro. Departamento de Artes e Design. III. Título. 


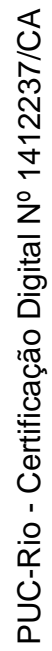

Para meus amados filhos, Eric e Fabrício. 


\section{Agradecimentos}

Ao meu orientador e grande amigo Claudio Freitas de Magalhães, por compartilhar comigo o amor pelo design, tão essencial para a realização dessa dissertação. Crau, sem você esse trabalho não seria possível.

Ao CNPq e à PUC-Rio, pelos auxílios concedidos ao longo dessa pesquisa.

Aos meus professores Luiz Antônio Coelho, Manuela Quaresma, Rejane Spitz, Denise Portinari, Solange Jobim e Everardo Rocha, por me ajudarem a pensar e construir essa dissertação.

A meus colegas de turma pelos incentivos e aos professores da Comissão Examinadora; Jorge Lopes e Domingos Manfredi.

Aos meus colegas da PUC-Rio que foram muito generosos, dividindo comigo seus saberes: Guilherme Lorenzoni, Marcella Guerra, Mariana Gioia, Daniel Nasajon, Brunna Paiva, Bruno Trindade, Gerson Ribeiro, Flavio Carvalho, Simone Belmonte, Sidnei Paciornik, Natascha Scagliusi, Guilherme Toledo, Eliane Garcia, Gilberto Mendes, Celso Wilmer, Jorge Langone, Fatima Santos, Haimon Alves, Gamba Jr e Marcos Henrique de P. Maurício. Meu muito obrigada ao biólogo Claudio Nicoletti de Fraga pela disponibilidade e paciência em ensinar um pouco de biologia para uma designer.

Aos meus filhos Eric e Fabrício, à minha mãe Gloria, e à minha família por todo apoio, estímulo, paciência e compreensão nesses últimos dois anos em que estive absorta e envolvida por essa pesquisa, que muito me gratificou. 


\section{Resumo}

Kayat, Habib Claudia; Magalhães, Claudio Freitas. Inovação em Design de Embalagem, por meio da Biomimética e das novas tecnologias digitais. Rio de Janeiro, 2015. 150p. Dissertação de Mestrado - Departamento de Artes \& Design. Pontifícia Universidade Católica do Rio de Janeiro.

A embalagem está no centro de questões de sobrevivência alimentar para mais de sete bilhões de pessoas no mundo. A presente pesquisa tem uma característica exploratória, voltada a investigar se as novas tecnologias digitais (especialmente microtomografia e impressão 3D) potencializam as abordagens de pensar e projetar embalagem por meio de analogias entre biologia e design (Biomimética). Tem também, uma característica experimental, objetivando estimular a criação e prototipação de conceitos inovadores biomiméticos para embalagem de alimentos. Os métodos utilizados foram: pesquisa bibliográfica, documental e de campo; entrevistas com especialistas (biólogos); coleta de materiais biológicos (especialmente frutos) e experimentação - que foi realizada em dois momentos: Experimento A, onde aplicou-se o pensamento biomimético baseado na abordagem "Biologia para Projetar" (Biomimicry 3.8, 2007), sem uso de novas tecnologias e Experimento B, onde aplicou-se o mesmo pensamento, porém com uso de novas tecnologias (microtomografia e impressão 3D). Graças ao processo de design exploratório e experimental, chegou-se a um conceito de design, que foi resultado de um desdobramento das analogias geradas entre biologia (vagem do amendoim) e design (embalagem). Ele propõe um sistema biomimético inovador para embalagem de alimentos que: aumenta a proteção e conservação, reduzindo o desperdício, permite adaptação a diferentes formatos e dimensões do conteúdo a ser embalado e otimiza o uso de materiais e processos. O resultado final alcançado faz-nos vislumbrar uma série de desdobramentos dessa pesquisa, principalmente ao que se refere à viabilidade técnica e implementação industrial do sistema criado, a fim de que seu uso possa ser generalizado em larga escala e, desta forma, contribuir para gerar impacto positivo nas questões contemporâneas de acesso e preservação de alimentos.

\section{Palavras-chave}

Embalagens; alimentos; Biomimética; novas tecnologias (microtomografia, impressão 3D); inovação. 


\section{Abstract}

Kayat, Habib Claudia; Magalhães, Claudio Freitas. Innovation in Packaging Design, through biomimetic and new digital technologies. Rio de Janeiro, 2015. 150p. MSc. Dissertation - Departamento de Artes \& Design. Pontifícia Universidade Católica do Rio de Janeiro.

The packaging is at the heart of food survival issues for more than seven billion people in the world. This research has an exploratory characteristic, aimed to investigate whether the new digital technologies (specially microtomography and $3 \mathrm{D}$ printing) potentializes the approaches of thinking and designing packaging through analogies between biology and design (Biomimicry). It also has an experimental feature, aiming to stimulate the creation and prototyping of biomimetic concepts for innovative food packaging. The methods used were: bibliographical research, documentary and field; interviews with experts (biologists); collection of biological materials (especially fruit) and trial - which was held in two stages: Experiment A, which applied the biomimetic based thinking approach "Biology to Design" (Biomimicry 3.8, 2007), without the use of new technologies and Experiment B, where we applied the same thought, but with the use of new technologies (microtomography and 3D printing). Thanks to the exploratory process of and experimental feature, this research came to a design concept, which was the result of a breakdown of analogies generated between biology (pod peanuts) and design (packaging). He proposes an innovative system for Biomimetic package for foods which: increase the protection and conservation, reducing waste, allows adaptation to different shapes and dimensions of the content and optimizes the use of materials and processes. The end result achieved makes us glimpse a number of developments of this research, especially when it comes to the technical feasibility and industrial implementation of the system introduced in order to allow its use to be widespread on a large scale and thus help to generate positive impact on contemporary issues of access and preservation of food.

\section{Keywords}

Packaging; food; Biomimetics; new technologies (microtomography, 3D printing); innovation. 


\section{Sumário}

1. Introdução 19

1.2 Métodos 23

2. Analogias para inovar 26

2.1. Design por analogia 28

2.1.1. Sinética 31

2.1.2. Analogias biológicas 33

2.2. A perspectiva da Biomimética para o design de embalagem 45

2.2.1. Embalagem e biomimetismo: casos exemplares 46

3. O processo de Design Biomimético 50

3.1. Metodologias que apoiam o Design Biomimético 52

3.2. Bases de dados que dão suporte ao Design Biomimético 61

4. Experimentos Biomiméticos para o Design de Embalagem 65

4.1. Experimento A 67

4.1.1. Etapa A1: Descobrir modelos naturais 68

4.1.2. Etapa A2: Selecionar o organismo inspirador 79

4.1.3. Etapa A3: Abstrair estratégias biológicas 81

4.1.4. Etapa A4: Identificar a função e definir o contexto 89

4.1.5. Etapa A5: Brainstorm- ideias bioinspiradas 90

4.1.6. Conclusão do Experimento A 92

4.2. Experimento $B \quad 93$

4.2.1. Etapa B1: Abstrair estratégias biológicas 96

4.2.2. Etapa B2: Identificar a função e definir o contexto 109

4.2.3. Etapa B3: Brainstorm 1: primeiras ideias bioinspiradas 110

4.2.4. Etapa B4: Emular conceitos de design do Brainstorm 1

4.2.5. Etapa B5: Brainstorm 2: novas ideias bioinspiradas 125

4.2.6. Etapa B6: Emular conceitos de design do Brainstorm 2 
4.2.7. Etapa B7: Explorar e validar o conceito de design mais promissor para o Design de Embalagem bioinspirada

4.2.8. Conclusão do Experimento $B$

5. Conclusão

6. Referências Bibliográficas 


\section{Lista de Figuras}

Figura 1 - Esquema do processo de analogia

Figura 2 - Esquema do processo de mapeamento do conhecimento 29

Figura 3 - Design gráfico de embalagem para remédios 30

Figura 4 - Imagem de página do livro On Growth and Form, 191733

Figura 5 - Imagem de Arctium (carrapicho) e de Velcro

Figura 6 - Imagem dos pés do Gekco e do protótipo do robô inspirado em seu funcionamento

Figura 7 - Testes com o protótipo do RiSE

Figura 8 - Testes com o protótipo do RiSE 39

Figura 9 - Imagem de Geko e solado de sapato 40

Figura 10 - Imagem do molusco Chaetopleura Apiculata

Figura 11 - Imagem do RoboBees 42

Figura 12 - Imagem do RoboBees 42

Figura 13 - Hugh Herr usando a prótese biônica 43

Figura 14 - Carro biomimético Renault 44

Figura 15 - Imagem do Fresh Paper 47

Figura 16 - Embalagem "Bacs" 48

Figura 17 - Imagem do produto Ooho 49

Figura 18 - Lente Elementos Essenciais 57

Figura 19 - Lente Princípios da vida 58

Figura 20 - Lente "Desafio para Biologia" 59

Figura 21 - Lente "Biologia para projetar" 60

Figura 22 - Imagem do site asknature.org 62

Figura 23 - Plataforma didática on-line 62 
Figura 24 - Ilustração com partes constituintes de flor completa

Figura 25 - llustração com esquema corte longitudinal de uma flor, mostrando seus elementos básicos reprodutores

Figura 26 - Desenho esquemático do processo de fecundação de uma flor

Figura 27 - Ilustração de sistema flor, fruto e semente

Figura 28 - llustração com exemplos de diferentes tipos de adaptações para disseminação de frutos e sementes

Figura 29 - Laboratório de Sementes Jardim Botânico RJ (LS)

Figura 30 - Visita guiada, agosto de 2015, ao arboreto do JBRJ

Figura 31 - Amostras de Clusia Lanceolata coletadas em visita ao arboreto do JBRJ

Figura 32 - Análise em campo do material coletado

Figura 33 - Materiais biológicos coletado pela autora

Figura 34 - Amostras de Clusia Lanceolata (coletadas em visita ao arboreto do JBRJ) e analisadas no NEXT

Figura 35 - Amostras de Urucum coletadas em visita ao arboreto do JBRJ e analisadas no NEXT

Figura 36 - Amostras de Gustavia Augusta coletadas em visita ao arboreto do JBRJ e analisadas no NEXT

Figura 37 - llustração de fruto do tipo vagem, de uma leguminosa (ervilha), com sementes

Figura 38 - llustração de Arachis Hipogea L.

Figura 39 - Visita do biólogo Dr. Claudio Nicoletti de Fraga ao NEXT etapa de abstração de estratégias biológicas do amendoim

Figura 40 - Vagens do amendoim com o conjunto de casca e bagas 82

Figura 41 - Casca da vagem do amendoim e sua linha de quebra após aplicação de pressão na região longitudinal

Figura 42 - Casca de vagens do amendoim aberta longitudinalmente em duas partes 
Figura 43 - Fruto do amendoim aberto e sua aparência interna e externa

Figura 44 - Desenhos feitos a partir de observação a "olho nu" da casca do amendoim, representando a configuração estrutural da mesma

Figura 45 - Análise invasiva, por meio de fricção, da casca da vagem do amendoim com suas fibras e multicamadas

Figura 46 - Análise do sentido do crescimento das fibras da vagem do amendoim

Figura 47 - Desenhos, em vistas, das linhas de força estruturais da vagem do amendoim

Figura 48 - Análise de "depressões" na superfície externa da casca da vagem do amendoim

Figura 49 - Desenho, a partir da observação a "olho nu" de detalhe de "depressões" na superfície externa da casca do amendoim

Figura 50 - llustração do fenômeno de geocarpia, onde o amendoim desenvolve-se subterraneamente

Figura 51 - Sketches com geração de ideias a partir da transferência de estratégias de linhas de força

Figura 52 - Sketches com geração de ideias a partir da transferência de estratégias de linhas de força

Figura 53 - Sketches com geração de ideias a partir da transferência de estratégias formais

Figura 54 - Sketches com geração de ideias a partir da transferência de estratégias de padrões geométricos

Figura 55 - Microtomógrafo LPDI e da equipe do LPDI durante a microtomografia dos materiais dessa pesquisa

Figura 56 - Urucum no arboreto do JBRJ e sua visualização (uma camada) em microtomógafo

Figura 57 - Clusia Lanceolata (fruto fechado e aberto e flor) no arboreto do JBRJ

Figura 58 - Clusia Lanceolata (fruto) e sua visualização 3D em microtomógafo 
Figura 59 - Preparação do amendoim para ser microtomografado no Xradia 510 Versa no LPDI

Figura 60 - Visualização 3D da vagem do amendoim microtomografado no Xradia 510 Versa no LPDI

Figura 61 - Visualização 3D da vagem do amendoim microtomografado no Xradia 510 Versa no LPDI

Figura 62 - Imagens adquiridas no microtomógrafo com a sequência de camadas da vagem do amendoim, usando-se o software Mimics

Figura 63 - Imagens adquiridas no microtomógrafo com a sequência de camadas da vagem do amendoim, usando-se o software Fiji

Figura 64 - Comparação entre representação da casca do amendoim após observação a "olho nú" (a) e imagens adquiridas pelo microtógrafo do amendoim, evidenciando sua estrutura alveolar (b)

Figura 65 - Comparação entre: representação da casca do amendoim após observação a "olho nú" (a) e imagens adquiridas pelo microtógrafo do amendoim, evidenciando sua estrutura alveolar (b)

Figura 66 - Área de "quebra" da vagem do amendoim observada a "olho nú"

Figura 67 - Visualização 3D da vagem do amendoim, a partir de dados primários adquiridos na microtomografia, evidenciando duas fendas logitudinais, configurando uma área de fragilidade na casca. Imagem digitalizada no software Rhinoceros

Figura 68 - Visualização 3D da vagem do amendoim. Corte transversal evidenciando estrutura alveolar. Imagem digitalizada no software Rhinoceros

Figura 69 - Visualização 3D da vagem amendoim (corte longitudinal), evidenciando sua estrutura alveolar. Imagem digitalizada no software Rhinoceros

Figura 70 - Desenhos representando a estrutura alveolar da casca do amendoim e as fendas longitudinais

Figura 71 - Representação da estrutura alveolar da casca do amendoim 
Figura 72 - Seção do amendoim digitalizada no software Rhinoceros e preparação para exportação do arquivo para a impressora 3D

Figura 73 - Materialização, por meio de prototipagem rápida, da seção da vagem do amendoim em escala ampliada, impressa na CubePro com filamento ABS

Figura 74 - Impressora CubePro iniciando a impressão do arquivo de seção da vagem do amendoim em escala ampliada

Figura 75 - Desenho à mão livre representando ideia para embalagem, usando analogia com a estrutura alveolar da vagem do amendoim

Figura 76 - Desenho à mão livre representando ideia para embalagem, usando analogia com a estrutura alveolar da vagem do amendoim

Figura 77 - Modelagem do volume formal no Solidworks

Figura 78 - Corte no volume para visualização das estruturas alveolares projetadas

Figura 79 - Detalhe do corte no volume, para visualização das estruturas alveolares projetadas

Figura 80 - Desenho à mão livre para construção paramétrica

Figura 81 - Desenho de programação paramétrica em Solidworks

Figura 82 - Desenvolvimento de diferentes formatos de alvéolo

Figura 83 - Formas rapidamente geradas com a programação paramétrica em Solidworks

Figura 84 - Desenho à mão livre representando ideia para embalagem, usando analogia com a linha de "soldagem" da vagem do amendoim

Figura 85 - Modelagem e impressão 3D

Figura 86 - Um dos lados do protótipo (b) com um ovo

Figura 87 - Modelagem do conceito (c) com linha frágil de "soldagem" no centro da embalagem

Figura 88 - Protótipo (c) sendo fabricado na impressora 3D Felix com filamento PLA 
Figura 89 - Protótipo (c) pronto para teste

Figura 90 - Frame do vídeo de experimentação da quebra por esforço manual na linha de "soldagem". Protótipo (c)

Figura 91 - Protótipo (c) quebrado por esforço manual

Figura 92 - Detalhe da estrutura alveolar interna e da linha de "soldagem" do protótipo (c)

Figura 93 - Sketches com a ideia de eliminação da parede externa 120

Figura 94 - Protótipos sem as paredes externa e internas retiradas à mão com micro retífica

Figura 95 - Protótipo (b) para dois ovos vazado à mão com microretífica

Figura 96- Detalhe do conceito de design (e) sem a parede externa e dimensionado para um ovo

Figura 97 - Detalhe do conceito de design (e) sem a parede externa e dimensionado para um ovo

Figura 98 - Protótipo (e1) executado na Makerbot com filamento de pó de madeira

Figura 99 - Protótipo (e2) executado na Makerbot com filamento SemiFlex

Figura 100 - Protótipo (e2) sendo testado com um ovo

Figura 101 - Protótipo (e3) executado na Makerbot com filamento NinjaFlex

Figura 102 - Protótipo (e3) executado na Makerbot com filamento NinjFlex

Figura 103 - Frame extraído do vídeo de experimentação com protótipo (e3) de resistência à queda. Momento 1

Figura 104 - Frame extraído do vídeo de experimentação com protótipo (e3) de resistência à queda. Momento 2

Figura 105 - Desenhos à mão com a ideia de desalinhar os alvéolos 125

Figura 106 - Desenhos à mão com a ideia de desalinhar os alvéolos 125

Figura 107 - Desenhos à mão explorando analogias com alvéolos da vagem do amendoim 
Figura 108 - Sequência de desenhos explorando configurações de alvéolos

Figura 109 - Desenhos à mão explorando configurações de alvéolos 127

Figura 110 - Impressora Felix iniciando protótipo (f) 128

Figura 111 - Protótipo (f) impresso na Felix com filamento PLA 128

Figura 112 - Modelagem do conceito (g) - placa alveolar 128

Figura 113 - Desenho técnico do conceito (h) "face simples" e especificações dimensionais gerais da placa

Figura 114 - Modelagem do conceito (h) - placa alveolar

Figura 115 - Impressão 3D do conceito (h) na impressora Felix com NinjaFlex

Figura 116 - Protótipo placa "face simples" medindo 10×10 cm

Figura 117 - Protótipo 10×10 cm do conceito (h): placa alveolar face simples, impresso em 3D (Makerbot com NinkaFlex) e o processo de transformação do plano por meio de tensão mecânica

Figura 118 - Protótipo "face simples" medindo 10x10 cm do conceito (h) embalando algumas vagens de amendoim

Figura 119 - Detalhe das extremidades do protótipo (h) com cones invertidos, criando uma espécie de fechamento nas extremidades do cilindro e evitando que amendoins caíssem

Figura 120 - Protótipos de placas com diferentes dimensionais de cones

Figura 121 - Desenho técnico e especificações da Placa A 134

Figura 122 - Placa A, sendo testada na configuração para ovos 135

Figura 123 - Placa A, sendo testada na configuração para bananas

Figura 124- Placa A, sendo testada na configuração para tomates

Figura 125 - Placa A, sendo testada na configuração para tomates

Figura 126 - Placa sem furos entre os cones e a deformação do plano causada pela tensão mecânica 
Figura 127 - Comparativo entre placa sem furos e com furos entre os cones

Figura 128 - Modelagens digitais com desalinhamento de cones: com furos (a) e sem furos (b)

Figura 129 - Placa $10 \times 10 \mathrm{~cm}$ antes da inversão de cones

Figura 130 - Placa plana e as diversas transformações do plano obtidas

Figura 131 - Outra visão das diversas transformações do plano obtidas

Figura 132 - Três configurações formais diferentes obtidas com o mesmo plano a partir de pressão alternada dos alvéolos 
Vez, por outra, abandone a trilha e se embrenhe no bosque. Sempre que você agir assim, decerto encontrará algo que nunca viu antes.

\section{Alexander Graham Bell}

O Design tem que ser inovador, altamente criativo, e interdisciplinar, que responda às verdadeiras necessidades do homem. Há de estar orientado à pesquisa, e é preciso que deixemos de desonrar a própria terra com objetos e fabricações pobremente desenhadas.

Victor Papanek, 1973 


\section{Introdução}

Muitos são os desafios globais frente ao crescimento populacional previsto pela Organização das Nações Unidas (ONU, 2014). Seremos nove bilhões e setecentos milhões de habitantes no planeta em 2050. Em colóquio realizado em setembro de 2014, no Rio de Janeiro, intitulado "Os Mil Nomes de Gaia: do Antropoceno à Idade da Terra", filósofos, antropólogos, cientistas, arqueólogos, biólogos e políticos, problematizaram as relações entre homem, natureza, tecnologia, e evidenciaram que a Terra precisa de soluções integradas e interdisciplinares para sustentar tamanha complexidade derivada desse crescimento populacional. Em seu livro Ecology and Power (2012), o antropólogo Alf Hornorg afirmou que já é evidente que a degradação de nossa biosfera está estritamente conectada com aspectos econômicos e culturais, como por exemplo, o elevado padrão de consumo nos países desenvolvidos.

Por outro lado, nos países subdesenvolvidos, onde há fome, torna-se essencial otimizar a cadeia de valor do alimento a fim de aumentar sua proteção, conservação, distribuição e reduzir o desperdício, estimado em dois bilhões de toneladas/ano pela Organização das Nações Unidas para Alimentação e Agricultura, (FAO) $)^{1}$, em 2013.

Nessa perspectiva, a embalagem torna-se essencial. Ela está no centro de questões de sobrevivência alimentar para sete bilhões e duzentos milhões de pessoas hoje no mundo. A Organização Mundial da Embalagem (WPO) ${ }^{2}$ afirma que a embalagem é uma ferramenta que viabiliza a sociedade atual e que deve estar aliada à preservação da vida, da saúde e dos recursos naturais, e que seu avanço tecnológico é guiado pela busca de "melhor qualidade de vida por meio de melhores embalagens para mais pessoas" (WPO, 2011). Ainda, segundo posicionamento da WPO no paper "Packaging - An important tool for a sustainable society" (2011), nos últimos vinte anos as indústrias de embalagens vêm lidando com problemas cada vez mais complexos, que impõem soluções de embalagens mais eficientes

\footnotetext{
${ }^{1}$ www.fao.org

${ }^{2}$ www.worldpackaging.org
} 
ambientalmente, ou seja, que reduzam o uso de matéria-prima e energia, que sejam recicláveis e reutilizadas.

A importância de soluções inovadoras e sustentáveis para problemas globais complexos impõem à indústria, empresas, governo e consumidores, uma mudança de estratégia, de comportamento e de modelo mental, trazendo novos paradigmas baseados no pensamento híbrido (material e digital), sistêmico, tecnológico, criativo, interdisciplinar, com foco no humano e no olhar para a natureza, não só para domá-la como recurso, mas também como inspiração.

A busca por inspiração na natureza para solucionar problemas complexos estimulou áreas de conhecimento transdisciplinares que exploram o uso de analogias biológicas na atividade de projetar, entre elas a Biônica e a Biomimética. Designers, arquitetos e engenheiros, vêm se interessando por essa abordagem, há muito tempo. O biólogo e matemático escocês Darcy Thompson, em seu livro On Growth and Form, 1917, explorou diversas geometrias de organismos naturais e sua dinâmica de crescimento e processos físicos. Seus estudos influenciaram muitos arquitetos consagrados, entre eles, Calatrava, Frei Otto, Renzo Piano, a terem como objetivo projetual o uso de princípios construtivos dos organismos presentes na natureza.

O designer e educador austríaco, Victor J. Papanek, em seu livro, Design for the real world, 1973, afirma:

\begin{abstract}
A Biônica é, de fato, uma ciência que emprega uma estratégia de simulação da natureza, com a finalidade de produzir inovação tecnológica. A Biônica não se ocupa somente das formas das partes, ou da maneira das coisas, mas também de estudar como a natureza faz e propõe as coisas, de compreender a inter-relação das partes, a existência dos sistemas. (PAPANEK, 1973, p.6)
\end{abstract}

Recentemente um novo termo, Biomimética, foi cunhado por Janine M. Benyus, cientista e bióloga americana, autora do livro: Biomimética - Inovação Inspirada pela Natureza, 2003, que afirmou:

A Biomimética usa um padrão ecológico para ajuizar a 'correção' das nossas inovações. Após 3,8 bilhões de anos de evolução, a natureza aprendeu: $\mathrm{O}$ que funciona. O que é apropriado. O que dura. (BENYUS, 2003, p.15)

Conhecer as estratégias da natureza, - fotossíntese, automontagem, seleção natural, ecossistemas auto-sustentáveis, olhos, ouvidos, peles, conchas, neurônios, 
terapias naturais e outras coisas mais, abre uma ampla gama de possibilidades inventivas ao homem (Benyus, 2003).

No âmbito das embalagens, Benyus mapeou, em seu artigo Packaging Tips from the Porcupine Fish (2002), várias estratégias de organismos vivos quanto à proteção: impacto, arranhões e quedas, etc... Podemos citar uma dessas estratégias: folhas e sementes estão organizadas em uma sequência espiral (conhecida por sequência de Fibonacci) que permite um "embalamento" uniforme em qualquer fase de seu crescimento, ou seja, sem encher demais no centro e nem espalhar muito nas pontas (Benyus, 2002).

Porém, para que a prática do Design Biomimético seja adotada por mais projetistas e implementada em organizações empresariais de forma sistemática e consistente, são necessários métodos e tecnologias que ampliem o conhecimento biológico, apoiem a transferência desse conhecimento para a solução de problemas, e facilitem o uso de analogias com a natureza, para gerar ideias e criar valor (Shu, 2011).

As novas tecnologias digitais estão provocando mudanças sísmicas nas economias mundiais. Elas oferecem uma nova forma de aproximação e abordagem para lidar com a complexidade dos dias atuais, pois permitem comunicação ágil em rede, visualização e análise de dados, mudança de modelo fabril e de manufatura, entre outros. Existem muitas definições para complexidade, mas a maioria concorda que a complexidade de um sistema está ligada ao grau de dificuldade de prever as inter-relações potenciais entre suas partes. Erin Baumgartner, diretora adjunta do SENSEable City Lab, do Instituto de Tecnologia de Massachusetts (MIT), afirma que em que a cada trinta e seis horas a Humanidade produz cinco exabytes de informações (o equivalente a toda produção do início da História até o começo do século XXI). Baumgartner, em conferência no primeiro dia da EmTech Brasil 2015, aponta a importância de tecnologias capazes de processar, relacionar e analisar esses dados e cita um exemplo de como essas tecnologias emergentes estão provocando revoluções no gerenciamento urbano. Em recente experimento conduzido pelo MIT, informações de cento e setenta milhões de corridas da frota de taxis de Nova York foram capturadas durante um ano. Com algorítimos os pesquisadores descobriram que noventa porcento das viagens poderiam ser compartilhadas por duas pessoas. "Dessa forma pode-se diminuir o número de táxis em quarenta porcento, gerando assim um impacto significativo no trânsito de 
Nova York", diz Baumgartner. (Disponível em: <http://senseable.mit.edu/>. Acesso em 3 nov. 2015).

Também na Medicina novas tecnologias vêm provocando revoluções e grande avanço por meio de obtenção e visualização de imagens bem definidas do corpo humano através de tecnologias não invasivas, especialmente a ressonância magnética (RM). Em pesquisas conduzidas por Jorge Lopes, do Laboratório Next, na PUC-Rio, mulheres grávidas passam por exames de RM para aquisição de imagens de seus fetos e posteriormente essas imagens são tratadas digitalmente para que sejam representadas tridimensionalmente por meio de impressoras $3 \mathrm{D}$ de alta precisão. $\mathrm{O}$ resultado desse processo propicia, por exemplo, que mulheres com deficiência visual possam acompanhar no modelo 3D de seu feto o desenvolvimento de sua gestação (Lopes, 2013).

E o que dizer sobre nossa alimentação onde "em dez anos, a impressora 3D tomará o lugar do fogão em nossas casas", como afirma Márcio Miranda, pesquisador da Empresa Brasileira de Pesquisa Agropecuária (EMBRAPA) e Diretor Executivo do Centro de Gestão e Estudos Estratégicos em Ciência e Tecnologia (CGEE), em recente entrevista ao jornal O Globo. Entre os projetos dirigidos por Miranda no CGEE está o "Projeto Alimentos" onde 20 instituições e 120 pesquisadores buscam criar um mapa de como produzir mais alimentos no futuro de forma mais saudável, funcional, rastreada e customizada. (http://oglobo.globo. com/opiniao/para-ouvir-os-cientistas-17988867).

A tecnologia também está permitindo duplicar a cada cinco anos os conhecimentos da biologia e das ciências naturais a partir da ampliação do alcance da visão. Benyus, afirma:

Igualmente sem precedentes é o alcance da nossa visão: novos alcances e satélites facultam-nos a observação dos padrões da natureza, do interstício celular às vastidões interestrelares. Podemos sondar um ranúnculo com os olhos de um ácaro, pegar carona na viagem dos elétrons da fotossíntese, sentir a vibração de um neurônio em atividade ou assistir em cores, ao nascimento de uma estrela. Podemos ver, mais claramente do que nunca, como a natureza realiza seus milagres. (BENYUS, 2003, p.14).

Podemos então, nortear esta pesquisa a partir das seguintes questões: as novas tecnologias digitais, especialmente a microtomografia e a impressão $3 \mathrm{D}$, potencializam a Biomimética? Incitam designers a abordagens disruptivas e experimentais que favorecem a inovação, na medida que permitem a aquisição, o processamento, análise e prototipação de dados primários da natureza, melhorando a 
quantidade e qualidade de analogias e transferências de princípios da natureza para o design de embalagem? E finalmente, como administrar estes aspectos no processo de design?

Essa pesquisa tem como objeto a influência das novas tecnologias digitais (microtomografia e impressão 3D) para um design Biomimético de embalagem inovadora, e visa o seguinte objetivo geral: desenvolver soluções conceituais inovadoras para embalagens de alimentos, a partir da Biomimética apoiada por novas tecnologias digitais (microtomografia e impressão 3D).

Podemos enumerar os seguintes objetivos específicos:

1. Relacionar Biomimética e novas tecnologias com design de embalagem para alimentos;

2. Redefinir características das funções de proteção de embalagens de alimentos, com base no estudo Biomimético.

E objetivos operacionais:

3. Identificar nas bases de dados digitais http://www.asknature.org/ e http://eol.org/, ente outras, estratégias encontradas na natureza no que diz respeito a como a natureza contém, protege, armazena e distribui;

4. Categorizar, juntamente com biólogos, as estratégias biológicas encontradas e escolher as mais promissoras para aprofundamento;

5. Selecionar material biológico a ser examinado no microtomógrafo em busca de dados primários;

6. Fazer a transferência desses princípios de proteção encontrados na natureza, para o design de embalagem de alimentos;

7. Gerar, explorar e experimentar diversos protótipos (impressão 3D) em um processo de aquisição de conceitos inovadores Biomiméticos para embalagem de alimentos;

8. Desenvolver e validar o conceito de design mais promissor.

\section{2.}

\section{Métodos}

A presente pesquisa tem uma característica exploratória, voltada a investigar se abordagens de pensar e projetar embalagens por meio de analogias entre biologia e design (Biomimética) são potencializadas por novas tecnologias digi- 
tais, especialmente microtomografia e impressão 3D. Tem também, uma característica experimental, objetivando estimular a criação, materialização e prototipação de conceitos inovadores Biomiméticos, para embalagem de alimentos.

Os métodos de pesquisa escolhidos para essa investigação e experimentação foram: (1) pesquisa bibliográfica sobre Biomimética, processo de design e embalagens (em livros, artigos, internet; principalmente duas bases de dados: a ISI Web of Science e a Science Direct, ambas por sua abrangência e qualidade; (2) pesquisa de campo em ambientes naturais, principalmente no Jardim Botânico do Rio de Janeiro, para observações intuitivas sobre elementos da natureza (dados primários), entrevistas com biólogos e biomimeticistas, para absorver seu processo de trabalho e adquirir experiência; (3) pesquisas em bancos de dados biológicos (principalmente Asknature ${ }^{3}$ ), que proporcionam conhecimentos abrangentes sobre a vida na terra e que auxiliam o entendimento das estratégias da natureza; (4) experimentação baseada na abordagem metodológica Biomimicry Design Lens (Lentes Biomiméticas), especialmente o modelo Biology to design (Biologia para Projetar) do Biomimicry 3.8 (2013).

Cabe destacar que a experimentação foi estruturada em dois momentos; visando avaliar a influência do uso de novas tecnologias digitais: Experimentação A (sem uso de novas tecnologias digitais), e Experimentação B (com uso de novas tecnologias digitais).

A Experimentação A abrangeu as seguintes Etapas: Descobrir modelos naturais (A1); Selecionar organismo inspirador (A2); Abstrair estratégias biológicas (A3); Identificar função e definir contexto (A4); Brainstorm ideias bioinspiradas (A5).

Como a Experimentação B também foi realizada a partir do mesmo organismo inspirador, portanto, não foi necessário repetir as Etapas de descoberta de modelos naturais e seleção do organismo inspirador. A Experimentação B, portanto, abrangeu as seguintes Etapas: Abstrair estratégias biológicas (B1); Identificar função e definir contexto (B2); Brainstorm 1 - primeiras ideias bioinspiradas (B3); Emular conceitos de design do brainstorm 1 (B4); Brainstorm 2 - novas ideias bioinspiradas (B5); Emular conceitos de design do

${ }^{3}$ www.asknature.org 
brainstorm 2 (B6); Explorar e validar o conceito de design mais promissor para inovação de embalagem bioinspirada (B7).

Essa pesquisa está estruturada nos seguintes capítulos: 1). Introdução; 2). Analogias para inovar; 3). O processo de Design Biomimético; 4). Experimentos Biomiméticos para o Design de Embalagem; 5). Conclusão. 
2.

\section{Analogias para Inovar}

"A criatividade é o coração do design, em todos os estágios do projeto" (BAXTER, 1998, p.85). Desenvolver a capacidade criativa é importante para os designers, pois a mesma pode influenciar o sucesso de um novo produto, marca ou serviço, diferenciando-os pela novidade e qualidade, e aumentando sua competitividade e gerando inovação.

Ken Robinson, PhD, (professor emérito de Educação na Universidade de Warwick, Reino Unido), explica que criatividade é um processo de desenvolver ideias originais que contenham valor. Em seu livro (Libertando o Poder Criativo), ele explica a importância da criatividade:

Não importa quem você é nem o que faz, se está vivendo no planeta Terra está em meio a uma revolução global. (...) As duas grandes forças que movem essa dinâmica são a inovação tecnológica e o crescimento populacional. Juntas, elas vêm revolucionando nossa forma de viver e de trabalhar; esgotam os recursos naturais do planeta e mudam a natureza da política e da cultura.(...) Considerando a velocidade da mudança, empresas e governos reconhecem que a educação e o treinamento são as chaves para o futuro, e enfatizam a crucial importância de desenvolver a capacidade criativa e inovadora. Em primeiro lugar, é essencial gerar ideias para produtos e serviços novos e para a manutenção da competitividade. Em segundo lugar, precisamos que a educação e o treinamento capacitem as pessoas a um maior grau de flexibilidade e de adaptação, de forma que as empresas consigam acompanhar as mudanças dos mercados. (ROBINSON, 2001, p.21)

A National Academy of Engineering (NAE), na publicação Educating the Engineer of 2020 (2005), apontou as habilidades e os diferenciais necessários para os projetistas em 2020, como inventividade prática e criatividade e afirmou que os profissionais capazes de criar e desenvolver produtos e serviços inovadores serão mais bem pagos. (NAE, 2005).

Porém, ainda segundo Robinson (2001), há um entendimento equivocado de que somente pessoas especiais são criativas. A Criatividade é uma capacidade mental inerente a qualquer ser humano e deve ser estimulada. O processo criativo pode ser aprendido, desenvolvido e sistematizado, por meio de diversas técnicas. 
Robinson explica como novas rotinas e hábitos de pensamento podem liberar a energia criativa:

É possível pensar de forma original em todas as atividades. No ritmo diário de nossas vidas, naturalmente adotamos rotinas de comportamento e hábitos de pensamento. Quando encontramos um problema ou uma situação nova, nossos costumes já incorporados podem dificultar a identificação de soluções originais. Existem diversas ferramentas e técnicas para ajudar a liberar formas de pensamento que escapem do convencional, entre elas o pensamento lateral ou divergente. No pensamento lógico-dedutivo, as ideias se apoiam umas nas outras em movimentos cuidadosos e consistentes e levam a um número limitado de respostas possíveis (ou a apenas uma solução). Os pensamentos lateral e divergente funcionam por meio de associações bem mais livres: muitas vezes por meio de metáforas ou de analogias, ou mesmo da reformulação da pergunta com o objetivo de ampliar as possibilidades. (ROBINSON, 2001, p.157)

A Rede de Pesquisas da Mente em Albuquerque (Novo México, EUA), quer ir além, e busca comprovação científica para explicar os processos criativos. Pesquisadores, liderados por Rex Jung, professor assistente do departamento de neurocirurgia da Rede, estão mapeando o cérebro humano para saber que impulsos bioquímicos e reações físicas ocorrem durante atividades criativas. O estudo, com sessenta e cinco pessoas, sugere que a criatividade prefere caminhos mais lentos e sinuosos que a inteligência. No caso da inteligência, esclarece Jung (2010), o cérebro parece ser uma super-rodovia eficiente, que o leva do ponto A para o ponto B. Mas nas regiões do cérebro relacionadas à criatividade parece haver rotas alternativas e estradas auxiliares pequenas e sinuosas, caracterizando um processo mais lento entre o ponto A e o B. Jung, também explica que há dois movimentos cruciais para o modo de pensar criativo: a divergência - ampliar perspectivas, fazer associações diferentes, recorrer a conceitos novos - e a convergência - o foco nas aplicações práticas das novidades. O indivíduo criativo sistematiza seu processo: sabe quando aplicar técnicas de fluidez criativa e analogias, a fim de gerar muitas ideias, e também sabe o momento de focar na solução e desenvolvêla para implementá-la com sucesso. "Criatividade é essa capacidade de ver possibilidades que os outros não enxergam e contribuir com algo original e útil". (JUNG, 2010).

Mike Baxter (diretor do Design Research Centre e professor do curso de Design da Universidade de Brunel, Inglaterra), extraiu do livro Techniques of Structured Problem Solving (Van Gundy, 1988), cento e cinco técnicas para estimular a criatividade e as relacionou com cada etapa do processo criativo, a saber: 
preparação, geração de ideias; seleção da ideia, revisão do processo criativo. O uso de analogias é uma das técnicas mais utilizadas para estimular a criatividade na etapa de geração de ideias (Baxter, 2010).

\section{1.}

\section{Design por analogia}

Os psicólogos americanos Gentner e Markman (1997) fizeram diversas pesquisas para entender o processo cognitivo que as pessoas usam para criar e entender analogias e metáforas. Descobriram que é um processo baseado principalmente em observação, associações, comparações, correspondências, semelhanças, similitudes, memória e combinação de conceitos que em princípio não estavam relacionados, gerando assim, soluções, ideias originais e inovações. Em sua pesquisa Structure Mapping in Analogy and Similarity, os pesquisadores explicam que o processo começa quando uma pessoa aprende um novo conhecimento e codifica a Fonte de inspiração para um problema futuro. Em algum momento do futuro, a pessoa se depara com um novo problema e deve recuperar (lembrar-se), de uma Fonte adequada de ideia para resolver o novo problema (Figura 1). Esse é o passo mais difícil cognitivamente do processo: recuperar uma analogia útil. Uma vez que uma Fonte é lembrada, um mapeamento é criado entre a Fonte e a nova situação-Alvo. Ao desenvolvermos esses mapeamentos, criamos novas ideias. (Gentner e Markman, 1997).

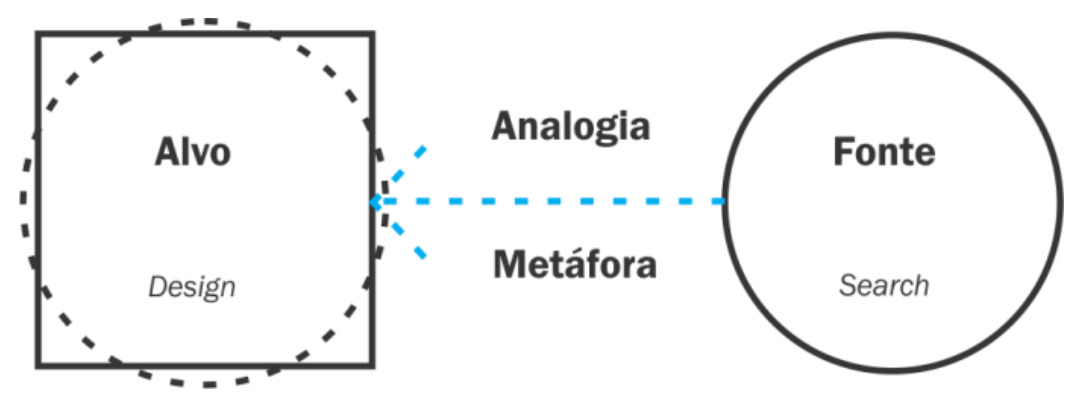

Figura 1. - Esquema do processo de analogia.

O artigo “Analogies and Metaphors in Creative Design” (Hey et al, 2008), aponta que analogias e metáforas podem ser vistas como um mapeamento do conhecimento de uma situação para outra - ativado por um sistema de relações ou representações entre as situações. Esse processo de comparação promove novas 
influências e permite interpretar problemas de novas maneiras, mais inovadoras e perspicazes. Por exemplo, uma equipe de design com o problema de projeto de criação de um dispositivo de dobrar roupa lavada, pode criar múltiplas representações linguísticas sobre o problema, como rolar, compactar, colapsar, franzir, etc...Cada representação irá disparar diferentes analogias com outros tipos de dispositivos de dobrar, tais como dobradura de papel ou dobrar metal (Figura 2). (Hey et al, 2008).

\section{Criar várias representações linguísticas}

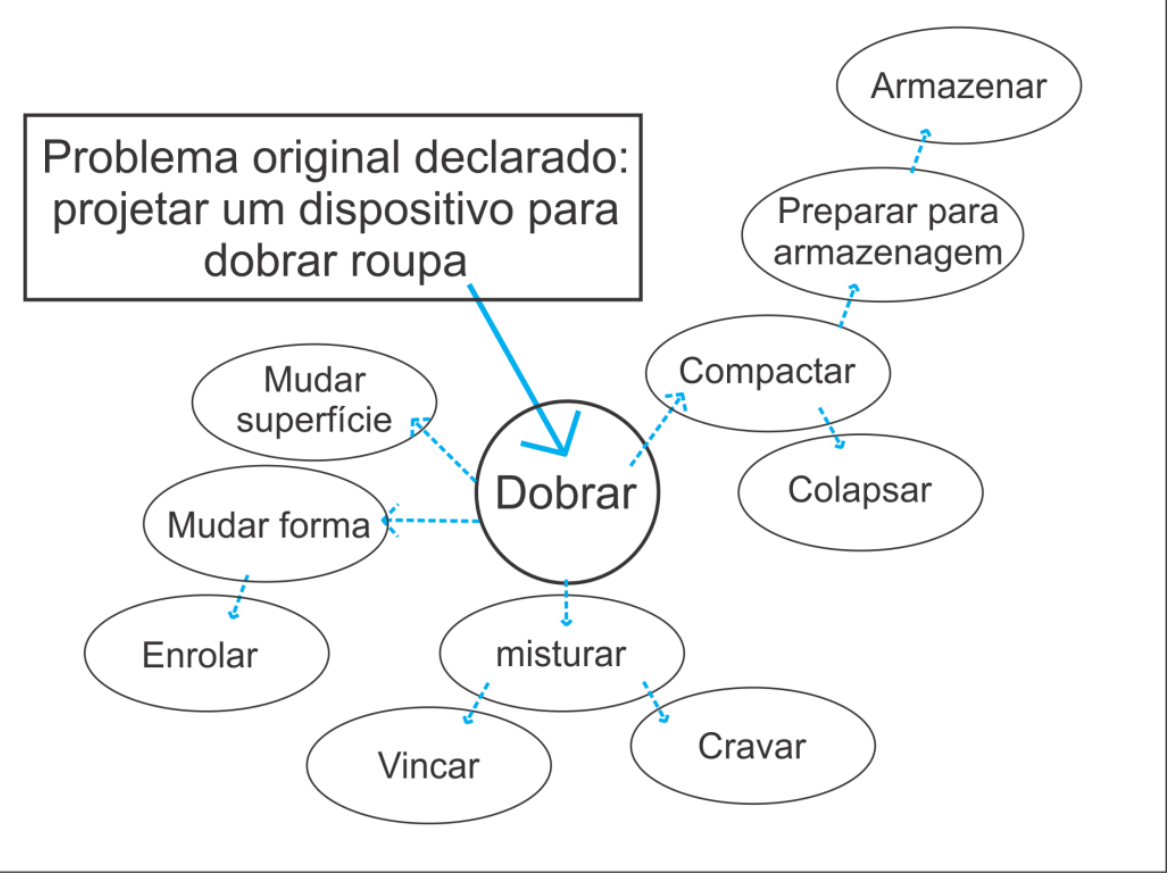

Figura 2 - Esquema do processo de mapeamento do conhecimento.

Ainda segundo o estudo acima, o potencial para resolução criativa de problemas é mais perceptível, quando os domínios comparados são muitos diferentes na superfície e em campos de conhecimento distantes um do outro.

Segundo Baxter (1998, p. 116), “analogia é uma espécie de raciocínio, em que propriedades de um objeto são transferidas para outro objeto diferente, mas com certas propriedades em comum”. Ele enumera quatro tipos de analogias: proximidade (papel-lápis), semelhança (domingo-feriado), contraste (gordo-magro) e causa-efeito (chuva, inundação). Elas são usadas para estimular o pensamento lateral (bissociação) e a capacidade de fazer novas associações, a fim de ultrapas- 
sar as ideias mais óbvias. Podem criar soluções completamente novas, descobrindo-se como um problema semelhante é resolvido em contexto diferente.

Ilustramos, com a imagem abaixo, o uso de analogia no design, ou seja, como a natureza comunica que a banana está estragada por meio de manchas e a transferência dessa "solução" para o rótulo de remédios, comunicando que o mesmo está fora da validade.
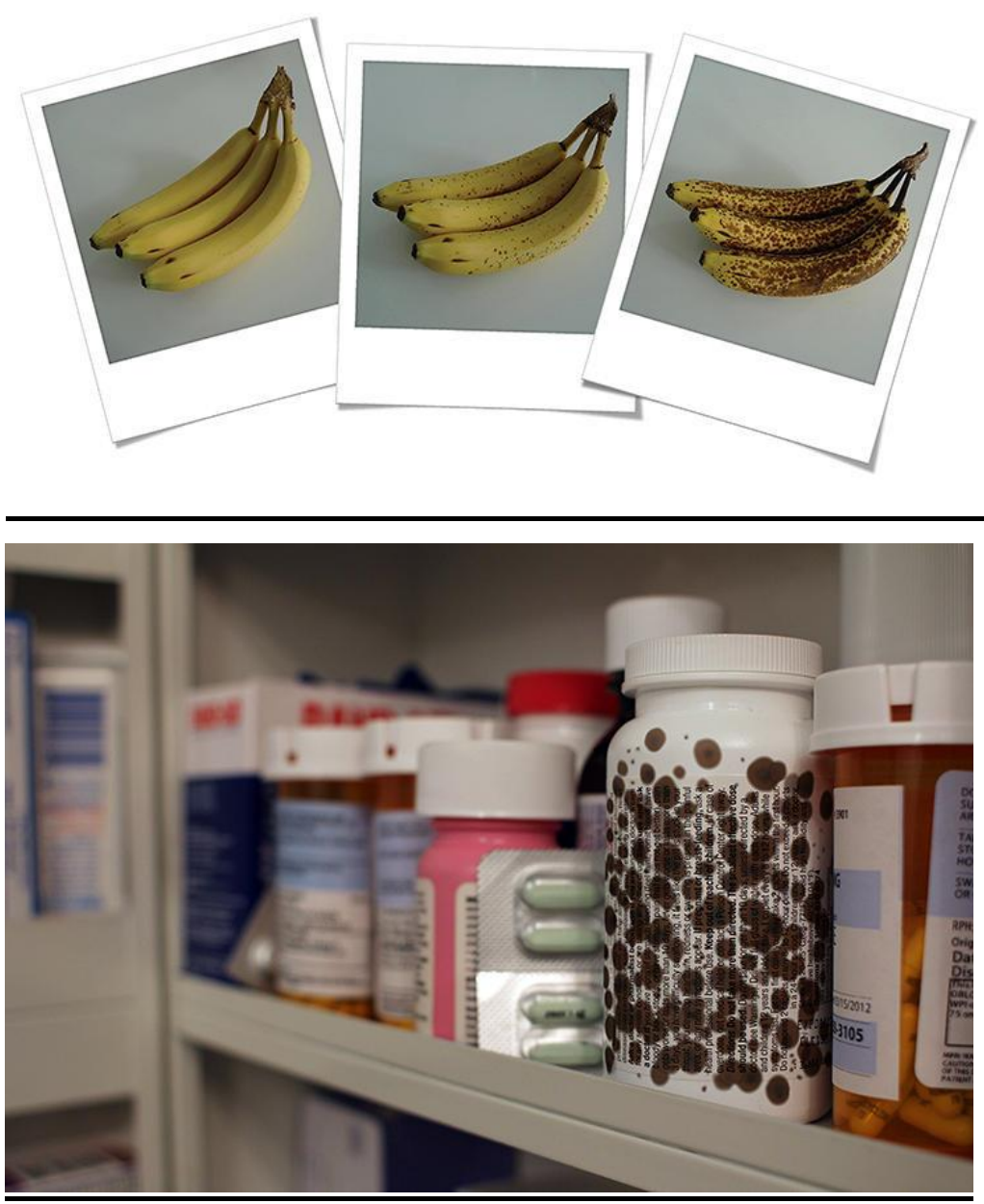

Figura 3 - Design gráfico de embalagem para remédios, usando analogia com a natureza. Imagem disponível em <http://www.pinterest.com/pin/282178732877521603/>. Acesso em: 20 nov. 2014.

O jornal da Universidade de Cambridge, Reino Unido, destaca a relevância de ferramentas para apoiar analogias:

Design por analogia é um a poderosa parte do processo de design, entre uma larga variedade de modalidades usadas pelos designers, tais como descrição linguística, sketches e diagramas. Precisamos de ferramentas para dar apoio às capacidades das pessoas para encontrar e usar analogias. (SAMBASIVA R. BHATTA AND ASHOK K. GOEL, 1996, p. 131-136). 


\subsection{1. Sinética}

Uma técnica específica para estimular analogias é a chamada Sinética.

A palavra Sinética é derivada do grego e significa juntar elementos diferentes, aparentemente não relacionados entre si. A técnica de Sinética foi desenvolvida por William Gordon, em 1957, como um aperfeiçoamento do método de brainstorming. (BAXTER, 1998, pg 105).

Em seu livro "The Practice of Creativity", William Gordon e George Prince reuniram suas experiências de muitos anos em treinamentos empresariais para desenvolvimento da capacidade criativa. Eles analisaram horas de gravações de reuniões de negócios para solução de problemas que tinham resultados inconsistentes, e chegaram à conclusão que era necessário um processo que estimulasse o pensamento aberto, o não julgamento e o uso de analogias para estimular resultados mais satisfatórios. Esse processo foi chamado por eles de Sinética, e uma vez implementado levou a mais criatividade e inovação no ambiente empresarial. A Sinética se aplica à integração de diversos indivíduos em um grupo de resolução de problemas. É uma teoria operacional para o uso consciente dos mecanismos psicológicos envolvidos na atividade criativa do homem a fim de estimular a solução de problemas. (GORDON, 1961).

Um grupo de Sinética é interdisciplinar, porém, "têm-se constatado a especial importância da participação de biólogos com estudos de biônica, fazendo analogias com seres vivos" (BAXTER, 1998, pg. 105). Aplica-se a Sinética quando buscamos soluções inéditas, ou quando desejamos fazer mudanças profundas em produtos e processos. As sessões são lideradas por um profissional que sabe o problema exato a ser resolvido, porém, para evitar ideias conservadoras, ele não o expõe ao grupo. Ao contrário, estimula a exploração de todos os aspectos possíveis e amplos do problema, pensando em sua essência e em termos abstratos, sem se fixar na forma atual de um produto, por exemplo: um abridor de latas. O problema real é melhorá-lo, mas o líder propõe ao grupo trabalhar o problema, explorando o conceito de "abertura". "Assim, o grupo deve pensar em todas as formas de promover essa abertura, inclusive procurando analogias na natureza" (BAXTER, 1998, pg.106), perguntando, por exemplo, como a natureza abre e fecha. 
"A Sinética reconhece dois tipos de mecanismos mentais": (BAXTER, 1998, pg 106) transformar o estranho em familiar e o familiar em estranho. O primeiro tenta, por meio de nosso condicionamento mental, enquadrar o que nos parece novo em algo que nos é familiar. Deste modo, acabamos por resolver os problemas de forma conservadora, com soluções tradicionais, já experimentadas por nós. Para inovar, no entanto, é necessário romper com essa tendência conservadora e transformar o familiar em estranho; invertendo, desmontando, montando de forma diferente, torcendo, aglutinando para olhar o problema conhecido sob novo ponto de vista, explica Baxter (1998).

Segundo Gordon (1961) são quatro tipos de analogias usadas pela Sinética: analogia pessoal, direta, simbólica e fantasiosa. Na analogia pessoal, a pessoa coloca-se mentalmente no lugar do processo, mecanismo ou objeto que pretende criar. Seguindo com o abridor de latas, você pode se imaginar como uma ponta de aço inox rompendo uma tampa de alumínio. Por sua vez, a analogia direta é muito usada na biônica, pois faz-se comparações com fatos reais, conhecimentos ou tecnologias. Usam-se imagens objetivas e impessoais para descrever o problema na analogia simbólica, por exemplo: "para o desenvolvimento de um mecanismo compacto para levantar pesos, imaginou-se uma corda indiana, que sai do cesto e fica em pé” (BAXTER, 1998, pg. 106). Por último a analogia fantasiosa, aquela que costuma dar 'asas' à imaginação, fugindo das leis e normas estabelecidas. Ela apela para a irracionalidade, para fugir das regras convencionais na busca de ideias originais e soluções inovadoras (GORDON, 1961).

Para entendermos a parte prática do uso da Sinética, tomemos o exemplo dado por Baxter (1998), em que numa sessão de ideação sobre o desenvolvimento de um telhado que tivesse maiores aplicações que um telhado tradicional foi aplicada a técnica de Sinética, especialmente a analogia direta por meio da biônica. Na preparação do problema o grupo (multidisciplinar) identificou que um telhado branco teria vantagens sobre o preto no verão e desvantagens no inverno. Então, se perguntaram: o que muda de cor na natureza? O grupo relacionou diversos animais que mudavam de cor sob determinadas circunstâncias, e chegaram ao exemplo do linguado, que fica branco quando está nadando sob areia branca, e escurece quando nada sobre o lodo escuro (mecanismo de proteção). Nesse momento, o biólogo presente no grupo passou a explicar cientificamente e detalhadamente o fenômeno o que provocou no restante do grupo uma série de ideias 
sobre como construir o telhado. Por fim, construíram uma analogia direta entre o linguado e o telhado. A solução foi usar um material preto com diversas bolinhas brancas embutidas nele. Quando o sol incidir sobre o telhado, este se aquece, e as bolinhas brancas se expandem emergindo a superfície.

\subsection{2.}

\section{Analogias biológicas}

Analogias tem papel significativo e estratégico na resolução de problemas, tomada de decisão, percepção, memória, comunicação, criatividade e inovação, e uma excelente maneira de sistematizar seu uso é imergir na natureza para buscar fontes de inspiração. Por meio de analogias com a natureza, podemos transferir informação e significado de um sujeito particular (natureza) para outro sujeito particular (por ex.: produtos).

Nos últimos cem anos, especialmente depois da segunda guerra mundial, os cientistas começaram a pesquisar nas ciências biológicas respostas para problemas humanos e obtiveram excelentes resultados.

O biólogo e matemático escocês Darcy Thompson, em seu livro On Growth and Form, 1917, explorou diversas geometrias de organismos naturais (Figura 4) e sua dinâmica de crescimento e processos físicos. Seus estudos influenciaram arquitetos, entre eles, Calatrava, Frei Otto, Renzo Piano, a terem como objetivo projetual o uso de princípios construtivos dos organismos presentes na natureza.

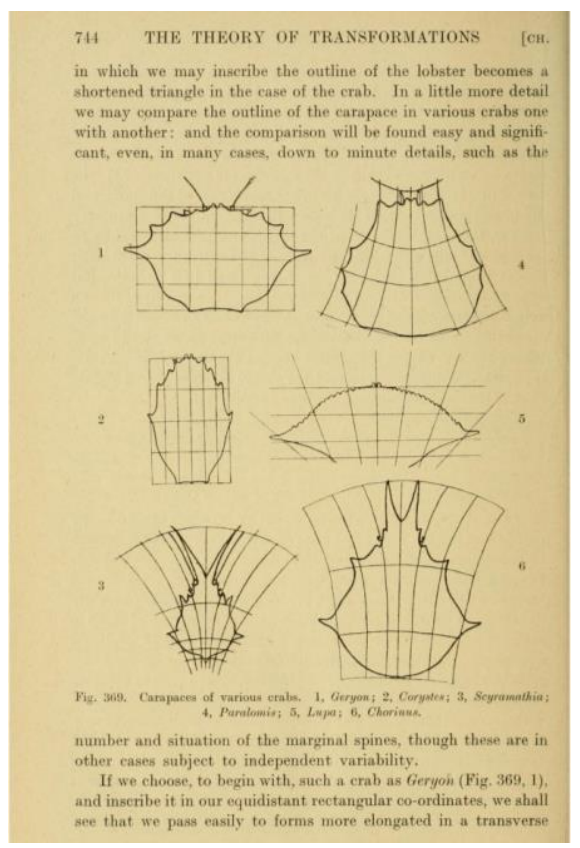

Figura 4 - Imagem de página do livro On Growth and Form, 1917. 
O exemplo clássico de inspiração na natureza é a invenção do Velcro, criado por George de Mestral em 1941. A ideia surgiu quando, após caminhada pelos Alpes Suíços, De Mestral retornou à sua casa com sementes de Arctium (carrapicho) coladas às suas roupas e aos pêlos de seu cão. Curioso, examinou o material através de um microscópio e conseguiu distinguir pequenos "ganchos" nas sementes que se entrelaçavam com filamentos do tecido, causando assim grande aderência entre as partes. Dessa observação e posterior pesquisa, De Mestral projetou um prendedor formado de duas partes: uma superfície com pequenos ganchos rígidos, como o carrapicho, e outra com pequenos laços flexíveis, como o tecido de sua calça. Assim nasceu o Velcro e a empresa Velcro Industries, fundada por De Mestral, e que hoje fatura milhões de dólares por ano graças às inúmeras aplicações do produto.
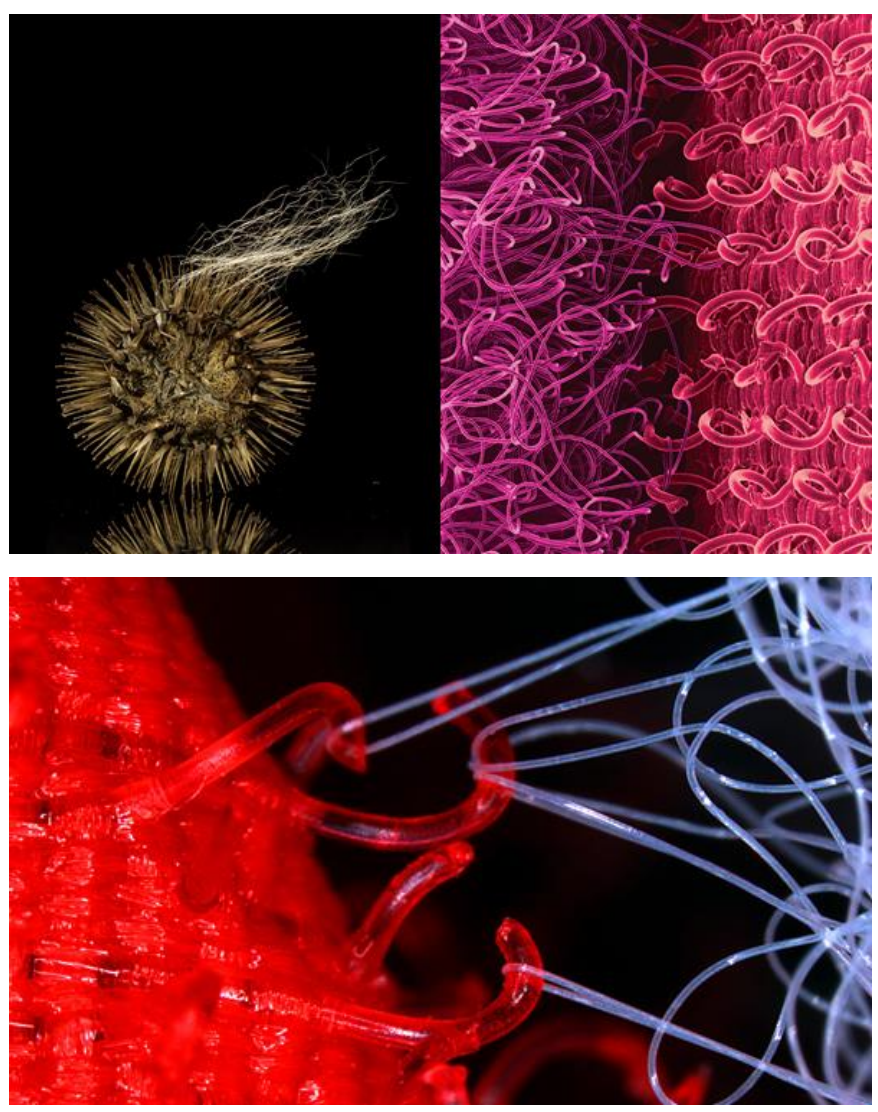

Figura 5- Imagem de Arctium (carrapicho) e de velcro. Disponível em: <http://archive.audubonmagazine.org/features0909/greenDesign-InspiredByNature.html >. Acesso em: 20 nov. 2014.

A literatura científica, a partir de 1960, cunhou diferentes termos para caracterizar esse processo de imitar modelos naturais, sistemas e processos para resolver problemas humanos. São eles: Biônica, Biomimética, Biomimesi, Biognosis, 
Bioinspiration, Design Bioanalogous, Design biologicamente inspirado, Biomimcry. Esses termos são muitas vezes considerados como sinônimos.

Em 1960, o Centro Wright Patterson, da aeronáutica dos Estados Unidos, em Ohio, promoveu um simpósio chamado Living prototypes - the key to new Technologies. No simpósio, o Major J.E.Steele apresenta o termo Biônica como uma nova fronteira da tecnologia através da fusão de disciplinas biológicas e físicas. Steele definiu que "Biônica é a ciência dos sistemas cujo funcionamento é baseado em sistemas naturais ou que guardem qualquer analogia com estes. (Wright-Patterson Air Force Base, Ohio, Directorate of Advanced Systems Technology, Wright Air Development Division, Air Research and Development Command, U.S. Air Force, 1961. Base de Dados: WorldCat). Os primeiros estudos realizados pela força aérea americana, segundo descrito na publicação acima, foram sobre a estrutura dos olhos das abelhas, e tinham como objetivo projetar um sistema de orientação que desfrutasse de luz polarizada.

Em 1973, Victor J. Papanek, um dos estudiosos mais entusiastas da Biônica, define o termo em seu livro Design for the real world:

Biônica significa 'a utilização de protótipos biológicos no design de sistemas sintéticos criados pelo homem'. Dito de maneira mais clara: se trata de estudar os princípios fundamentais da natureza e chegar a aplicação de princípios e processos às necessidades da humanidade. (PAPANEK, 1973, p. 190).

Papanek continua defendendo o uso da biônica:

O livro da natureza é um manual que nunca passará de moda. Nele, todos os problemas da humanidade e dos sistemas biológicos e bioquímicos já foram aceitos e resolvidos e mediante analogias, de maneira ótima. (PAPANEK, 1973, p. 190)

Em seu livro, acima citado, são detalhados inúmeros estudos biônicos com especial atenção às sementes: "se se deixa cair a cerca de um metro ou dois uma simples semente de Arce (Aceraceae Saccharum), ela descerá seguindo uma trajetória em espiral muito definida”. Papanek (1973) relata que uma das aplicações mais interessantes, usando sementes de Arce, foi projetada por um estudante de design e consistia em um novo método para "sufocar" incêndios florestais: com plástico barato e leve se construiu uma semente artificial de Arce com $22 \mathrm{~cm}$ de comprimento que continha um pó extintor de incêndios. Quando as sementes artificiais estavam para cair sobre o fogo as correntes térmicas ascendentes das chamas faziam com que o plástico derretesse e liberasse o pó extintor. Esse experi- 
mento biônico fez chegar módulos extintores a zonas inacessíveis pelos bombeiros.

Como defensor do Design Ético, Papanek conclui que:

Hoje já não é possível nem desejável desenhar nem um só produto que não esteja aparentado com seu entorno sociológico, psicológico e cidadão. Portanto, o designer deve encontrar analogias, utilizando não só a biônica, mas também os sistemas biológicos em sua aproximação ao design, tirados dos campos da ecologia e etologia. (PAPANEK, 1973, p. 191).

A Biônica também é definida como a junção da biologia com sistemas mecânicos e eletrônicos, resultando em produtos que funcionam como organismos vivos (Shu et al., 2011).

O termo Biomimética foi cunhado por Otto Schmitt, um cientista em Biofísica e bioengenharia, no título de um artigo apresentado em 1969, no Terceiro Congresso Internacional de Biofísica.

A definição de Biomimética apareceu pela primeira vez no dicionário do Webster em 1974 como: o estudo da formação, estrutura ou função de substâncias e materiais biologicamente produzidos (como enzimas ou seda) e mecanismos e processos biológicos (como a síntese de proteínas ou fotossíntese), especialmente com a finalidade de sintetizar produtos semelhantes por mecanismos artificiais que imitam os naturais. (VINCENT et al., 2006).

Seguiram-se outras definições do termo: "Biomimética é a realização de aplicações técnicas baseadas nos insights resultantes de fundamentos da investigação biológica". (SPECK \& SPECK, 2008, pg.3).

Benyus, cientista americana e autora do livro: Biomimética - Inovação Inspirada pela Natureza (2003) define Biomimética (Biomimicry) como uma nova ciência que estuda modelos da natureza e, em seguida, imita-os ou inspira-se neles para resolver problemas humanos. O termo Biomimicry tem uma conotação de sustentabilidade.

Biomimética é uma abordagem para inovação sustentável, que busca inspiração nas coisas vivas (biologia). É um campo singularmente interdisciplinar que reúne biólogos, engenheiros, designers, empreendedores e outros, para resolver problemas por entender e aplicar estratégias da natureza para solucionar problemas humanos. (BENYUS, 2011, http://biomimicry /digital_toolkit/index.html\#p=2)

Benyus (2003) apresenta essa nova ciência:

“Biomimética (Do grego bios, vida, e mimesis, imitação). 
1. A natureza como modelo. A Biomimética é uma nova ciência que estuda os modelos da natureza e depois imita-os ou inspira-se neles ou em seus processos para resolver os problemas humanos. Podemos citar, como exemplo, uma célula de energia solar inspirada numa folha.

2. A natureza como medida. A Biomimética usa um padrão ecológico para ajuizar a "correção" das nossas inovações. Após 3,8 bilhões de anos de evolução, a natureza aprendeu: o que funciona. O que é apropriado. O que dura.

3. A natureza como mentora. A Biomimética é uma nova forma de ver e valorizar a natureza. Ela inaugura uma era cujas bases assentam não naquilo que podemos extrair da natureza, mas no que podemos aprender com ela." (BENYUS, 2003, pg 8)

E propõe um mergulho na natureza para o conhecimento de infinitos exemplos de como revolucionar nossa vida:

Quando nos aprofundamos assim nas estruturas da natureza, ofegamos, assombrados, e, positivamente, nossas ilusões se desfazem. Percebemos que todas as nossas invenções já existem na natureza sob uma forma mais elegante e a um preço bem menor para o planeta. Nossas vigas e escoras já estão nas folhas do nenúfar e nas hastes do bambu. Nossos sistemas de aquecimento central e ar-condicionado são superados pelos estáveis trinta graus centígrados do cupinzeiro. Nosso radar mais sofisticado é surdo se comparado ao sistema de captação de frequências do morcego. E nossos "materiais inteligentes" não chegam aos pés da pele do golfinho ou da probóscide da borboleta. Até mesmo a roda, que sempre consideramos criação do homem, foi encontrada no minúsculo rotor que impele o flagelo da bactéria mais antiga do mundo. (BENYUS, 2003, p.14)

Não só os campos do design de produto, da engenharia e arquitetura, se beneficiam com essas soluções. Benyus (2011) mapeou estudos de um grupo de cientistas e inventores que já fizeram inovações com base na natureza em áreas como a de medicamentos (a partir da observação de hábitos alimentares de animais) e de sistemas administrativos e econômicos baseados em princípios das florestas de sequóias e de nogueiras, que usam os detritos como recursos para a sobrevivência. Quatorze dessas invenções inteligentes inspiradas na natureza estão na plataforma on-line do Bloomberg Business, 2015 (Disponível em: <http://www.bloomberg.com>. Acesso em: 5 nov. 2014), que conecta os tomadores de decisão a uma rede dinâmica de informações, pessoas e ideias, com rapidez e precisão e oferece informações comerciais e financeiras, notícias e conhecimento em todo o mundo. Esse fato comprova a importância atual da Biomimética para empresas que buscam a inovação. 
O termo Biomimética, amplamente aceito pela comunidade científica, será usado daqui para frente nessa dissertação quando nos referirmos às analogias biológicas, por uma questão de padronização.

Atualmente, diversos institutos de pesquisa científica (Harvard, Cambridge, Berkeley, MIT, etc...) especialmente ligados à engenharia, arquitetura, design e inteligência artificial, conduzem pesquisas em Biomimética, vislumbrando inúmeras aplicações comerciais de suas invenções.

Uma excelente referência para pesquisa em Biomimética, atualmente, é o Departamento de Biologia Integrativa na Universidade da California, em Berkeley. Sob a direção de Robert Full, o Poly-PEDAL Lab conduz estudos sobre o desempenho, a energética e dinâmica da locomoção animal, para transferir, com ajuda da computação e da engenharia, princípios da locomoção animal (como os animais se movem por músculos e esqueletos), para robôs. Uma dessas pesquisas estudou o Gecko (um pequeno lagarto do sul da França que se locomove em superfícies verticais lisas como o vidro), para inspirar robôs que escalam paredes (Figura 6).

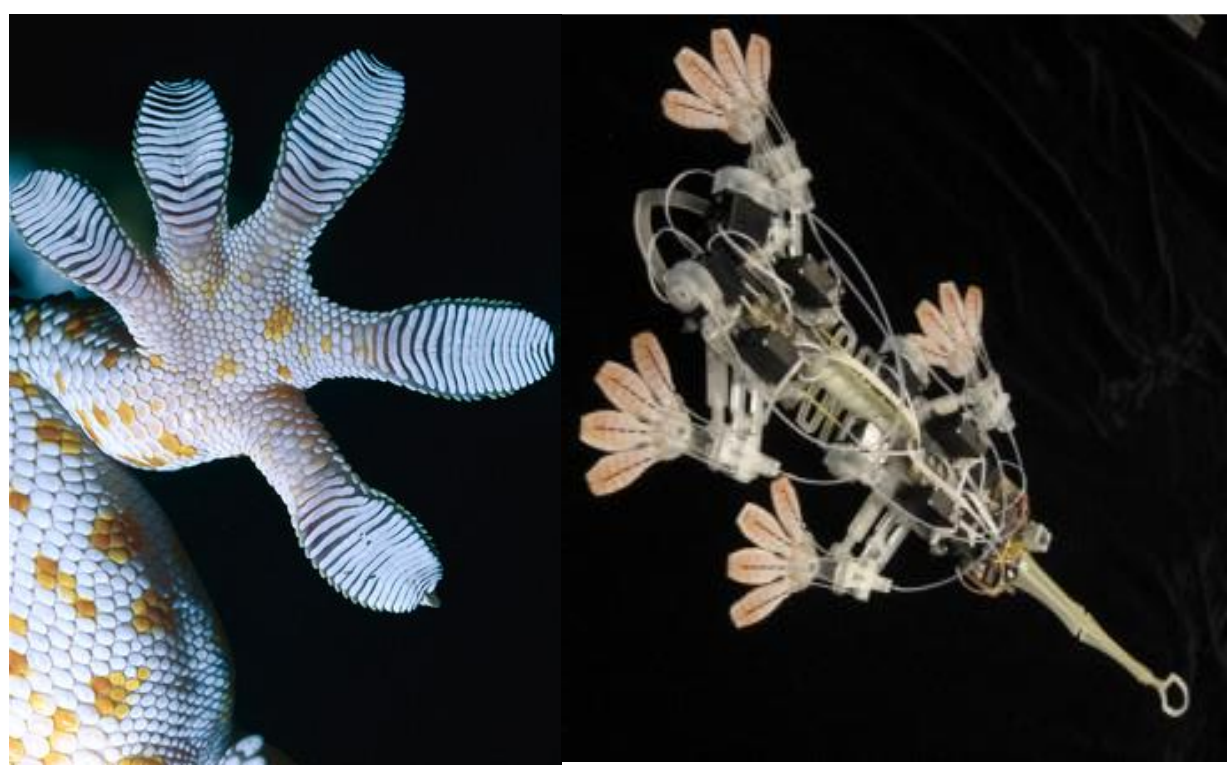

Figura 6 - Imagem dos pés do Gecko e do protótipo do robô inspirado em seu funcionamento. Disponível em http://polypedal.berkeley.edu. Acessado em 7 dez 2015.

Os dedos dos pés dos lagartos também são alvo de pesquisas científicas em nanoescala, conduzidas pelo Computational Materials Research Group (CMRG) da Universidade do Estado de Oregon, nos Estados Unidos. Pesquisadores desse 
grupo, liderados por Alex Greaney, descobriram que Geckos possuem milhões de pelos (também chamados de "setas") minúsculos e ramificados em seus dedos. Essas "setas" são capazes de "ligar" e "desligar" a sua aderência, "colando" e "descolando" os pés de superfícies verticais por meio da aplicação de uma força de deslizamento paralela a essas superfícies. Esse sistema de adesão permite que uma lagartixa se movimente a uma velocidade equivalente a vinte comprimentos de seu próprio corpo por segundo com um mínimo de energia. Desvendar tais mecanismos pode ser crucial, por exemplo, para criar adesivos e colas mais eficazes, explicam os cientistas. (http://research.engr. oregonstate.edu/greaney/content/ simulation-gecko-inspired-dry-adhesion-system).

O estudo do Gecko adquiriu enorme relevância hoje nos Estados Unidos, tanto que o atual estágio da pesquisa deu origem ao projeto RiSE e está sendo financiada pelo Programa Biodynotics do Defense Advanced Research Project Agencys (DARPA) e reúne as universidades americanas da Pensilvânia, Berkeley, Stanford e Harvard.

O projeto RiSe tem como objetivo criar um robô com capacidade de andar na terra e escalar superfícies verticais.

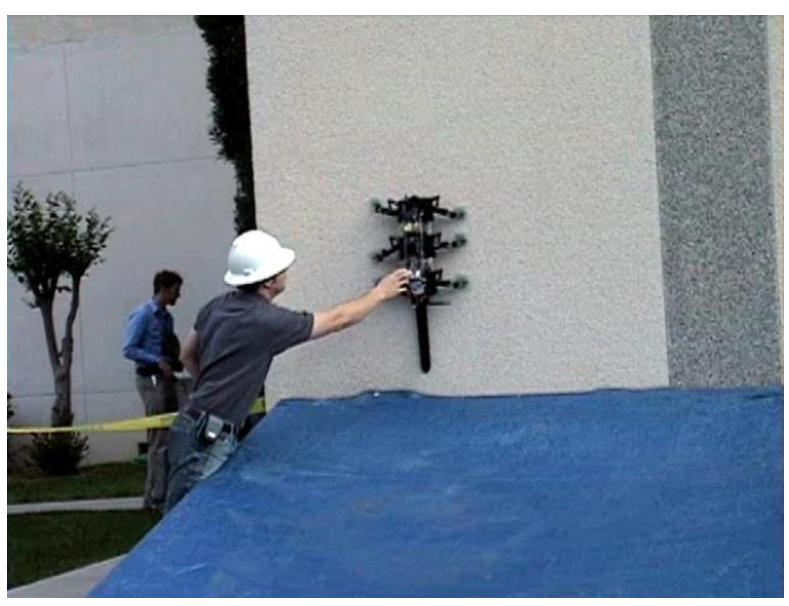

Figura 7 - Testes com o protótipo do RiSE. Disponível em: < http://kodlab.seas.upenn.edu/ rise > Acesso em: 6 dez. 2015. 


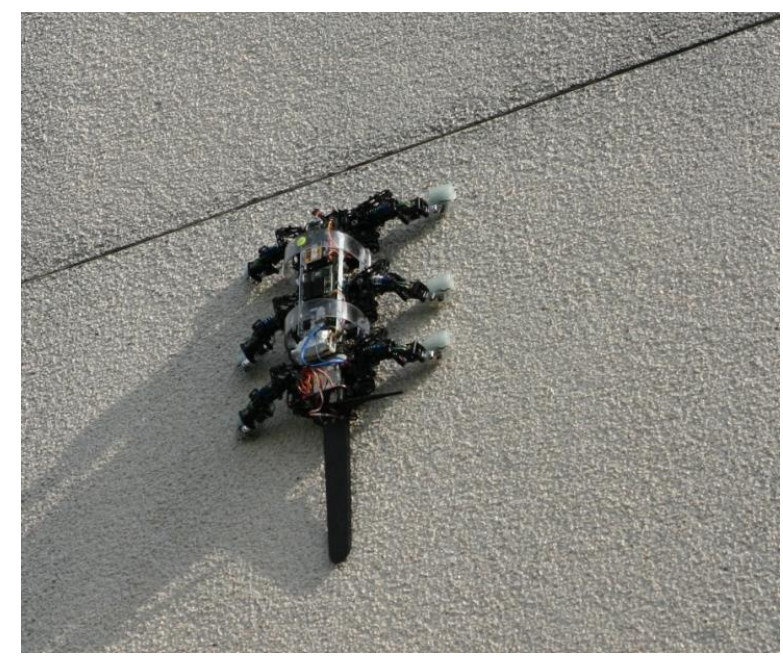

Figura 8 - Testes com o protótipo do RiSE. Disponível em: < http://kodlab.seas.upenn.edu/ rise > Acesso em: 6 dez. 2015.

É interessante comparar esse exemplo de Biomimética, do ano de 2015, com um exemplo utilizando o mesmo animal (Gecko), do ano de 1989, em que designers decodificaram a geometria e funcionamento das patas em forma de lâminas maleáveis para inspirar algumas solas de sapatos para caminhadas em terrenos de rocha escorregadia. (Figura 9).
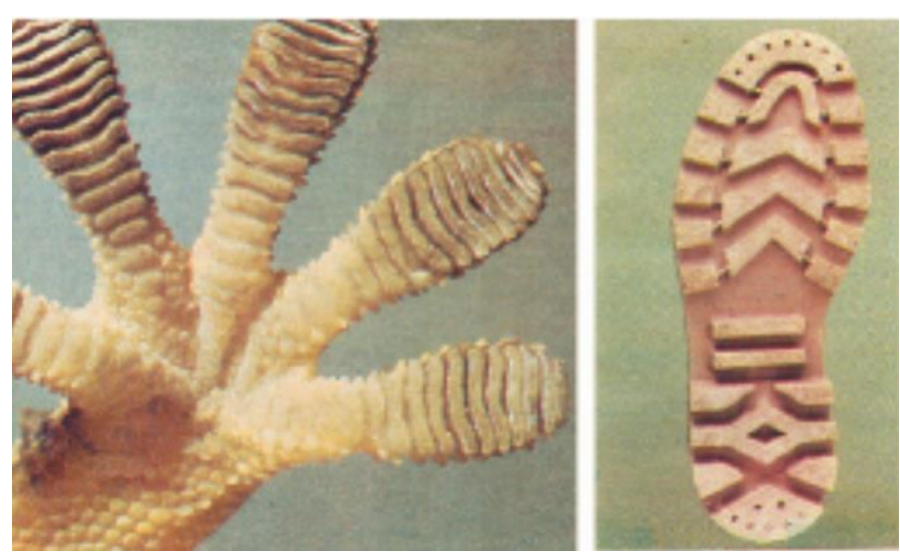

Figura 9 - Imagem de Gecko e solado de sapato, revista Manchete em 9/12/1989.

Verifica-se uma evolução considerável na transferência das analogias para produtos apresentadas nos exemplos acima (de solas de sapato para robôs), uma vez as tecnologias disponíveis hoje permitem um maior número e complexidade de dados, informações e visualizações em nanoescalas, capazes de revelar e explicar com maior acuidade o funcionamento de sistemas naturais.

David Kisailus, professor assistente no Departamento de Engenharia Química e Ambiental da Universidade da Califórnia, Riverside, desenvolve, desde 2015, materiais de construção que imitam a natureza. Ele estuda vários animais mari- 
nhos, por exemplo, o molusco Chaetopleura apiculata (Figura 10), que tem os dentes mais duros de todas as espécies conhecidas. Eles são feitos de magnetite, conhecido como óxido de ferro magnético, um material ultraduro, mais duro do que o óxido de zircônio usado em produtos abrasivos. Esse material permite que o molusco destrua rochas com os dentes para comer as algas que crescem dentro delas. (Disponível em: http://www.wired.com/2013/03/biomimetic-materials/>. Acesso em: 7 dez. 2015).

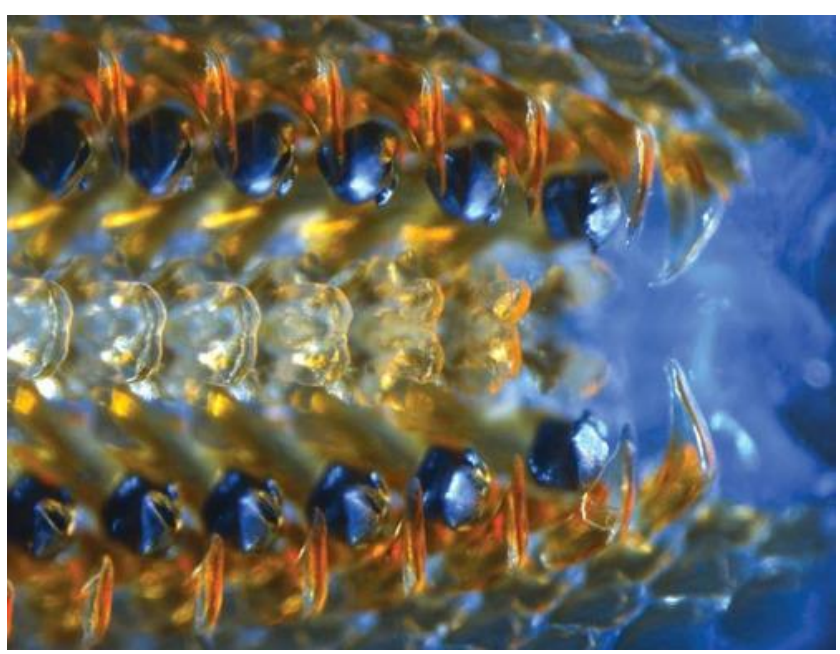

Figura 10 - Imagem do molusco Chaetopleura apiculata (detalhe dos dentes). Disponível em: http://www.wired.com/2013/03/biomimetic-materials/ acessado em 7 dez.2015.

O Instituto WYSS para Engenharia Biologicamente Inspirada (WYSS), na Universidade de Harvard, Boston, descreve a sua missão:

Nossa missão é desenvolver materiais biologicamente inspirados e dispositivos que solucionarão problemas médicos e ambientais críticos, e traduzir essas tecnologias transformadoras em produtos que tenham um impacto na sociedade e no mundo, (http://wyss.harvard.edu/viewpage/264).

É o caso do RoboBees (Figuras 11 e 12), um o robô inspirado na biologia de uma abelha. Os pesquisadores do WYSS vislumbram uma série de aplicações comerciais para os Robobees, que vão desde usos para agricultura (colheita e polinização), até salvamento em missões após desastres naturais, mapeamento do clima, de tráfego e ambiental. Para resolver problemas de projeto e implementar a produção em massa, os RoboBess contam com o financiamento externo da National Science Foundation. 
Os RoboBees são micro-veículos aéreos autônomos, medindo cerca de metade do tamanho de um clipe de papel, e pesando menos de um décimo de uma grama. Eles voam usando "músculos artificiais" compostos de materiais que contraem quando uma voltagem é aplicada.

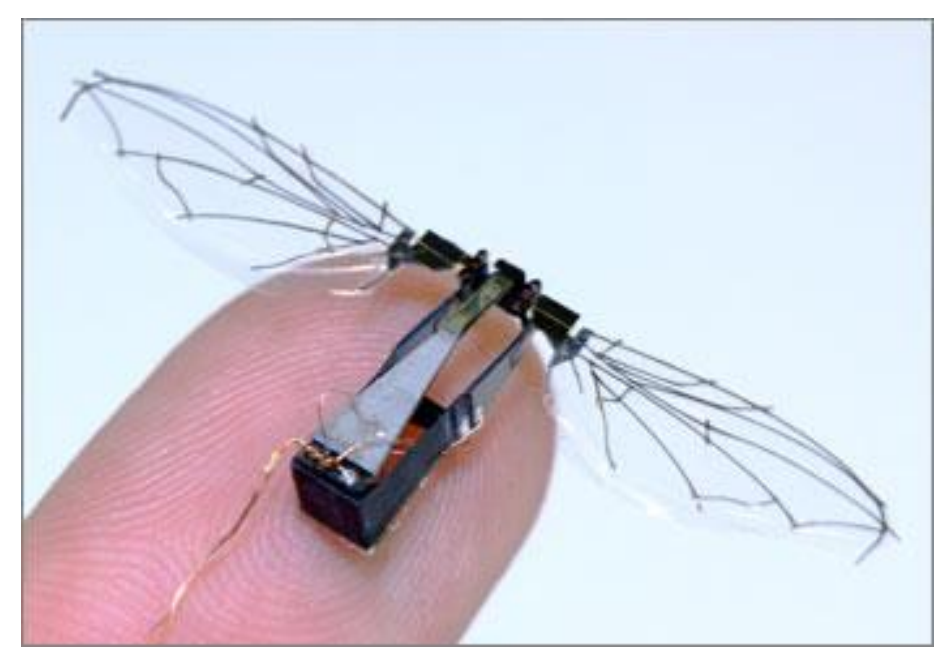

Figura 11 - Imagem do RoboBees. Disponível em:

<http://wyss.harvard.edu/viewpage/204/bioinspired-robotics>. Acesso em: 7 dez. 2015.

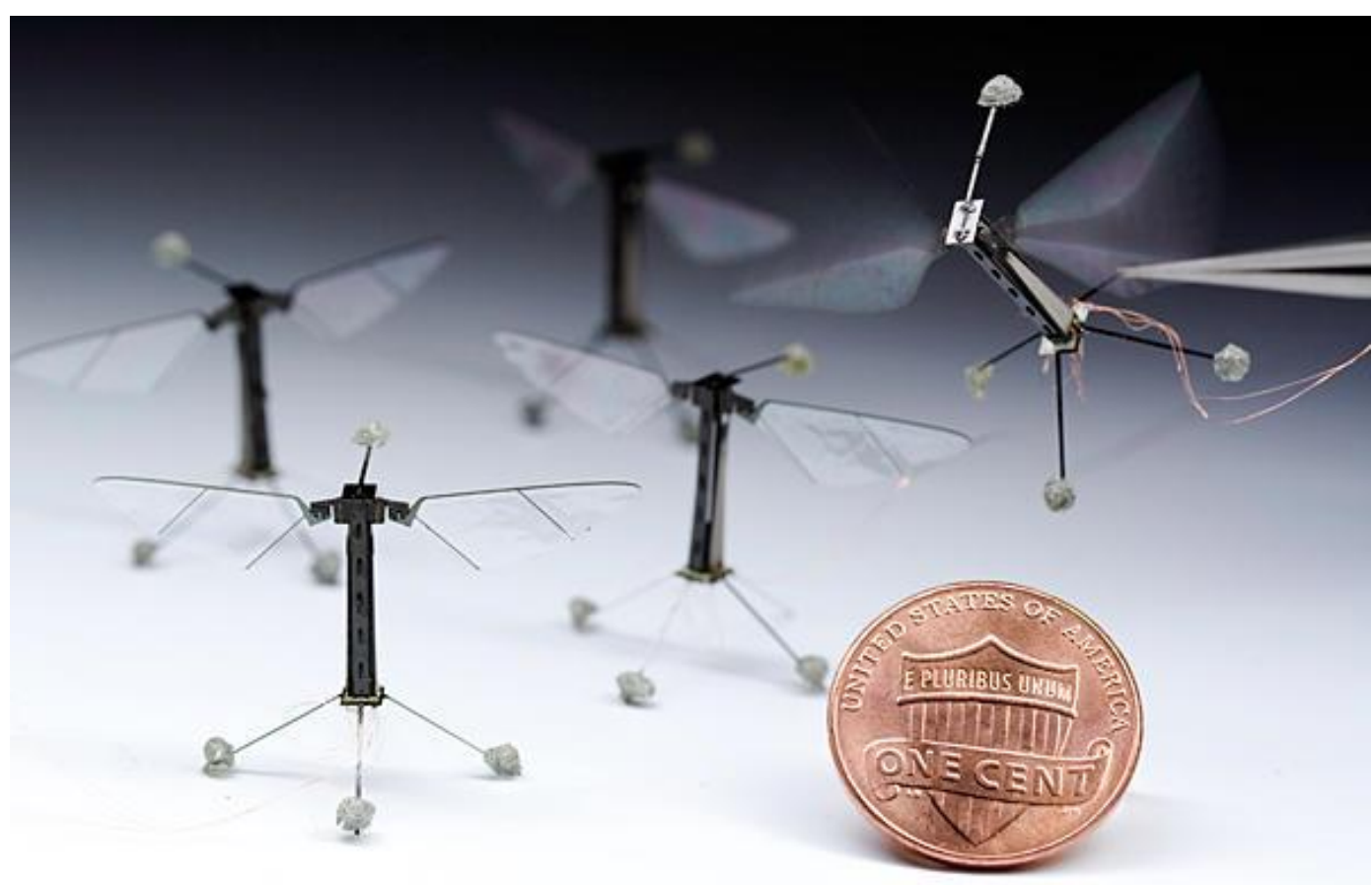

Figura 12 - Imagem do RoboBees. Disponível em: <http://wyss.harvard.edu/staticfiles/newsroom/pressreleases/RoboticInsectPhoto02.jpg > Acesso em: 7 dez. 2015. 
Hugh Herr dirige o grupo de pesquisa Biomecatrônica no MIT Media Lab’s. Herr, que é amputado dos membros inferiores, projetou próteses de pernas biônicas que, segundo ele, "imitam a natureza" - pois emulam o funcionamento de joelhos biológicos, tornozelos e panturrilhas. Ele próprio é usuário das próteses que o grupo de Biomecatrônica (MIT) criou, e que continuam sendo aperfeiçoadas em sua biomecânica e controle de movimento biológico. Herr, também criou a empresa BiOM, que produz tecnologia de propulsão biônica para substituir músculos perdidos e tendões. O Sistema T2 da BiOM fornece energia auxiliar para melhorar a mobilidade das pessoas com amputações de membros inferiores, e com isso facilitar a reabilitação humana (Figura 13).

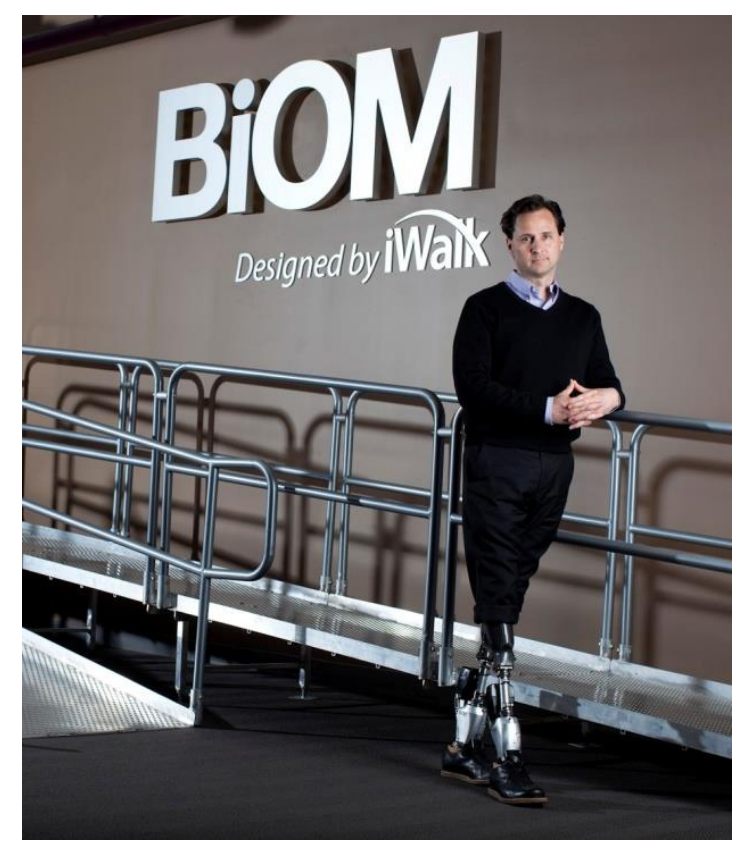

Figura 13 - Hugh Herr usando a prótese biônica. Disponível em: <http://www.activewirehead.com/bionic-leg-hugh-herr/>. Acesso em: 7 dez. 2015.

Podemos, também, exemplificar o uso de Biomimética na indústria automobilística com projeto de um carro conceito feito em parceria com o designer Ross Lovegrove e a fabricante de carros francesa, Renault (Figura 14). O resultado é o desenvolvimento de uma sintax visual baseada em padrões orgânicos. Lovegrove afirma que a intenção é "revelar os projetos da natureza" e transferí-los para uma nova linguagem de design. 


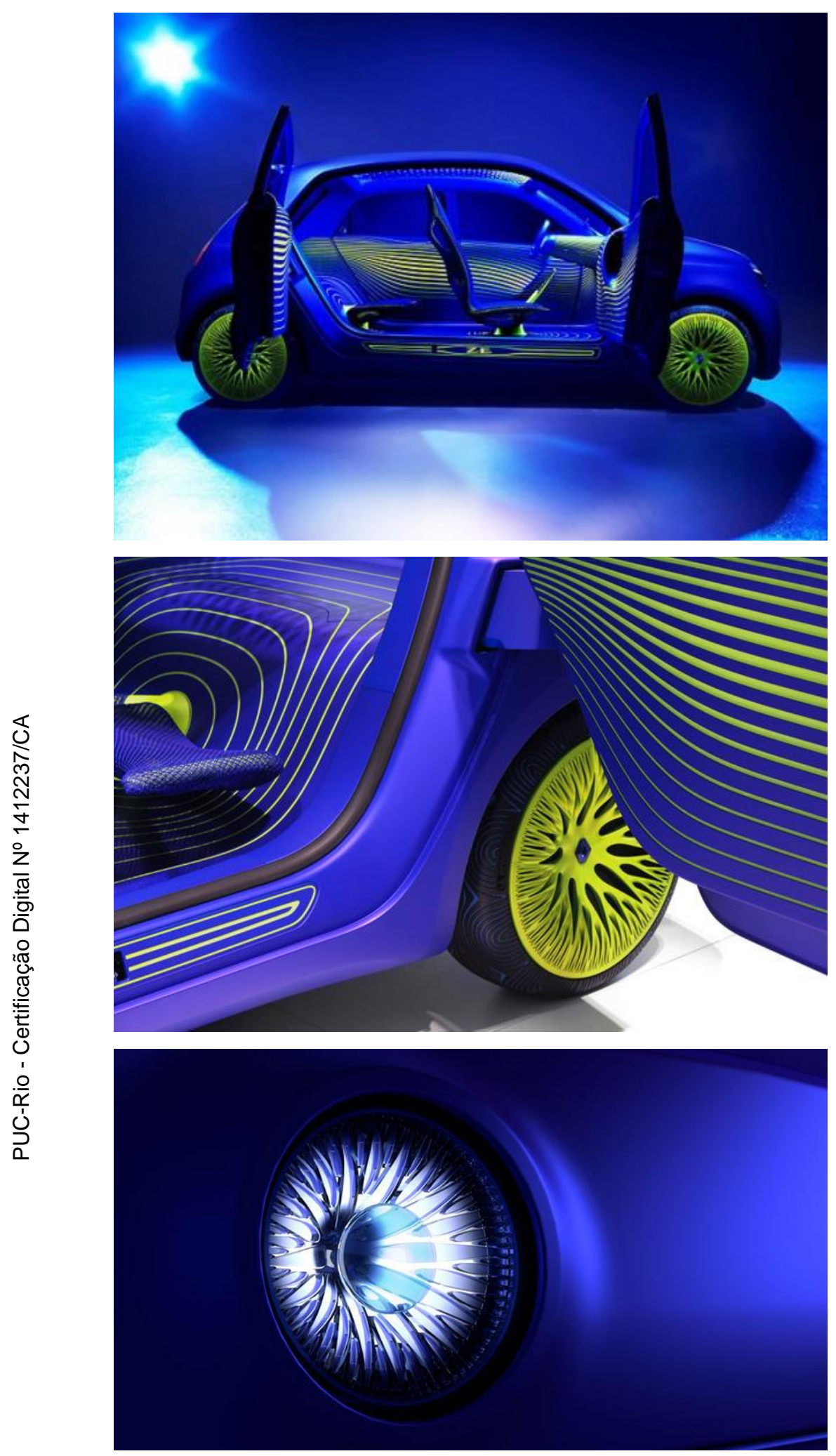

Figura 14 - Carro Biomimético Renault. Disponível em: http://www.fastcodesign.com/. Acesso em: 20 nov. 2014. 


\title{
2.2.
}

\section{A perspectiva da Biomimética para o Design de Embalagem}

Embalagens são uma parte inevitável da vida moderna. Elas preservam e protegem, permitindo às pessoas fazerem uso de coisas que foram produzidas longe ou há algum tempo.

\begin{abstract}
A embalagem realiza uma série de funções distintas. Ele protege o seu conteúdo de contaminação e deterioração. Ela torna mais fácil de transportar e armazenar mercadorias. Ele fornece medição uniforme do conteúdo. Ao permitir que marcas sejam criadas e padronizadas, faz a publicidade significativa e a distribuição em larga escala possível. Tipos especiais de embalagens, com tampas de dispensação, sprays e outros recursos convenientes, fazem os produtos serem mais usáveis. A embalagem serve como símbolo, tanto de seu conteúdo e de um modo de vida. E assim como podem muito poderosamente comunicar a satisfação que um produto oferece, são igualmente símbolos potentes de desperdício, uma vez que o produto é consumido. (HINE, 1995, pg.6).
\end{abstract}

É comum ouvirmos relatos acerca de como a natureza "embala" bem, e o quão bom seria se projetássemos embalagens tão perfeitas como as que encontramos no mundo natural: que protegem, facilitam o transporte e são naturalmente biodegradáveis.

Tomemos como exemplo a mexerica (Citrus reticulata). Além de seus atributos alimentares, podemos avaliar a "inteligência" de seu design que, entre outros benefícios, protege a polpa comestível por meio das propriedades de barreira de sua casca; espessura, fibras, resistência e impermeabilidade. A cor alaranjada transmite apelo ao apetite, e a textura da casca facilita a aderência à mão e transmite uma sensação boa ao ser tocada por sua forma arredondada do tamanho que cabe na mão do consumidor. É multicamadas, sendo as embalagens das porções individuais feitas com outro material com espessura mais fina, mas suficiente para proteger o produto, é fácil de abrir e pode ser consumida em qualquer lugar. Feita com material compostável, sua decomposição é rápida e não deixa resíduos tóxicos no solo. Caso a opção seja o não descarte, ela pode ser consumida na forma de doces e geléias. Possui concentrações elevadas de vitaminas A, B1, B2, Niacina, Vitamina C, cálcio e fósforo.

Podemos também citar alguns aspectos mercadológicos dessa fruta: sua indústria fabricante é mundial e possui vários tipos de produtos ao redor do mundo. A embalagem não possui registro de patente, pois a ideia do fabricante é que sirva 
de inspiração e possa ser copiada livremente. O lugar de fabricação é de porte médio e sua segurança é feita de forma natural com espinhos e galhos. A decoração é feita com flores brancas e aromáticas, semelhantes à laranjeira.

Inúmeros são os exemplos de boas embalagens na natureza, principalmente entre os frutos e sementes. As cascas das frutas, especialmente bananas, laranjas, melão, melancia, são excelentes embalagens naturais.

\subsection{1.}

\section{Embalagem e biomimetismo: casos exemplares}

O uso de analogias no design de embalagens pode ser exemplificado mais detalhadamente em um projeto recente e muito inovador. Trata-se da invenção da jovem designer indiana Kavita Shukla, que resolveu pesquisar o uso de especiarias, especialmente sua analogia com remédios. Quando em uma viagem à India, sua avó lhe deu um "chá de especiarias" para evitar que ela adoecesse por ter bebido água da torneira. Depois de anos de pesquisa, Kavita inventou o Freshpaper, um dos projetos vencedores do prêmio Index 2013, que reconhece as soluções de design sustentável para enfrentar desafios globais. O FreshPaper (Figura 15) é uma simples folha de papel repleta de especiarias orgânicas, que inibem o crescimento de bactérias e fungos, aumentando de duas a quatro vezes o prazo de validade de frutas e legumes e vegetais. A embalagem está disponível em lojas dos Estados Unidos, incluindo as gigantes Whole Foods e Wegmans, e é utilizada por agricultores e famílias em mais de 35 países. Também é possível obter o produto através do site da empresa de Kavita, a FenuGreen. A designer pretende utilizar o prêmio da Index, o equivalente a 100 mil euros, para aumentar a distribuição da embalagem na África e na Índia por meio de parcerias com ONGs e instituições de pesquisa. (Exame.com/Ecodesign |02/09/2013). 


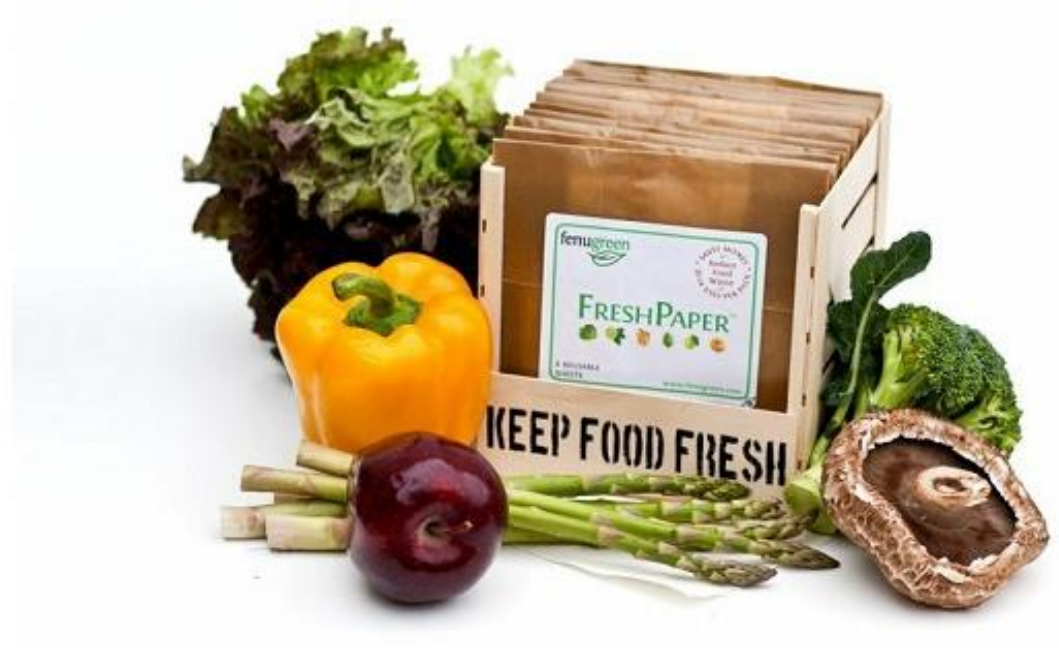

Figura 15 - Imagem do Fresh Paper.

Disponível em: < http://www.fastcoexist.com/1681042/7-young-entrepreneurs-changing-theworld-with-their-businesses>. Acesso em: 20 nov. 2014.

Um novo material de embalagem chamado "Bacs", desenvolvido pela designer Mareike Frensemeier, pretende revolucionar as embalagens nos próximos anos, tanto que ficou terceiro lugar no Cargo Packs 2020 (Disponível em: http://embalagemsustentavel.com.br/2009/11/14/embalagem-de-bacteria/).

Uma rede super-resistente de nano-fibras de celulose é construída em torno de objetos por bactérias Acetobacter xylinum pela metabolização de açúcar em glicose (Figura 16). Esse material pode ser usado para várias aplicações, segundo o site especializado em embalagens: "Embalagem sustentável".

No estado inicial amortece o impacto e mantém os alimentos frescos por mais tempo. Em seu estado seco, oferece um material de embalagem higiênica, na forma de um papel forte, podendo ser construído diretamente sobre a superfície do produto ou se transformar em uma determinada forma, adaptando-se ao produto. A terceira propriedade oferecidos pelo "Bacs" é a de uma espuma liofilizada que protege produtos sensíveis, com boas propriedades de isolamento e amortecimento. "Bacs" propõe a utilização de bactérias para converter a glicose em celulose. O produto resultante, que é produzido com eficiência energética e é ecológico na sua forma de auto-contrução. Pode ser usado como material alternativo de embalagem. (http://embalagemsustentavel.com.br/2009/11/14/) 

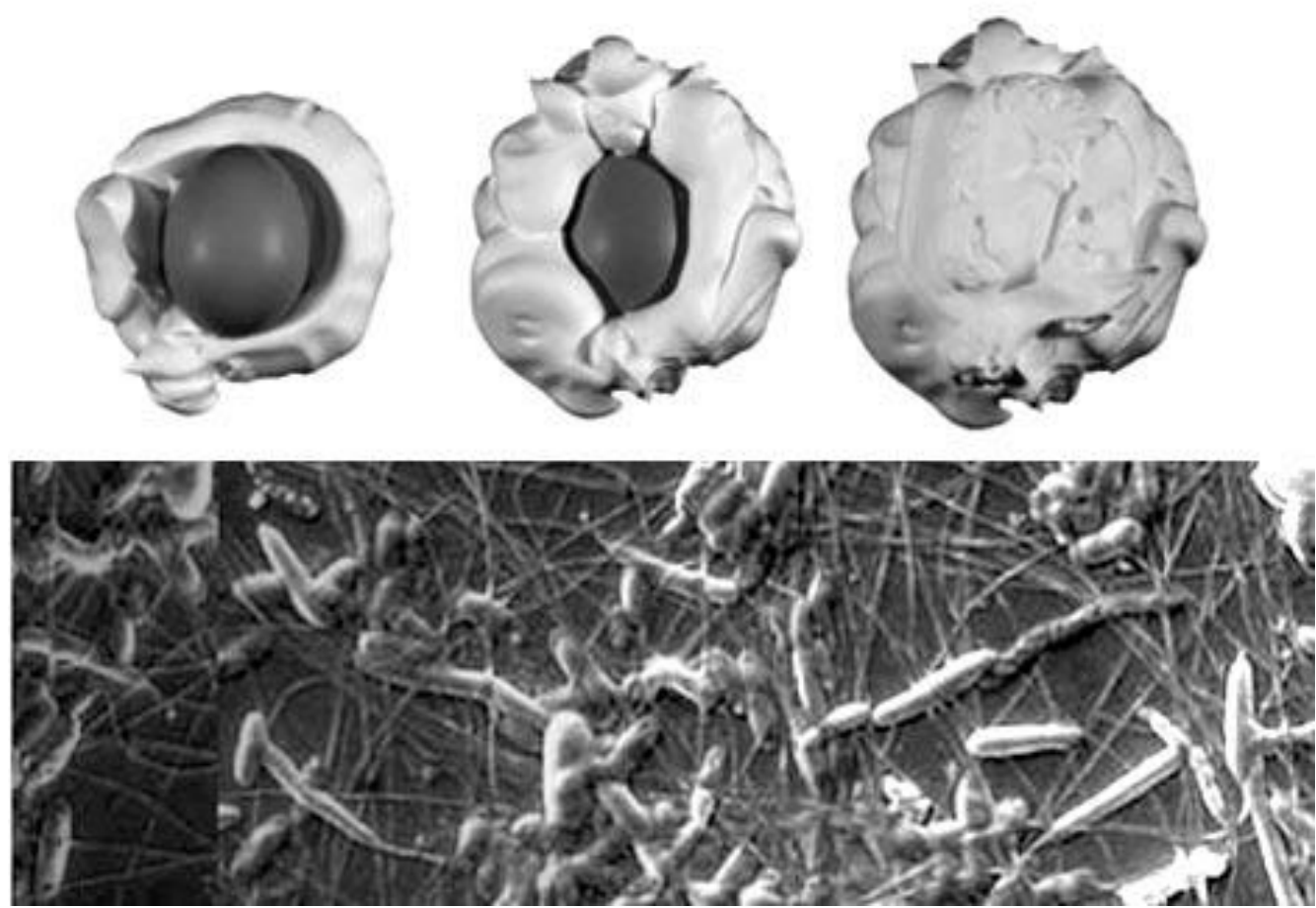

Figura 16 - Embalagem "Bacs".

Disponível em: <http://embalagemsustentavel.com.br/2009/11/14/embalagem-de-bacteria/>. Acesso em: 7 dez. 2015.

Outro projeto, inusitado e inovador, é o produto Ooho (Figura 17). Consiste em uma embalagem comestível e biodegradável para água mineral, inspirada nas águas-vivas. Criada pelos designers espanhóis Rodrigo García González, Guillaume Couche e Pierre Paslier, a embalagem é confeccionada a partir de algas marinhas e cloreto de cálcio e sua configuração lembra uma bolha gelatinosa, que pode ser colocada de uma vez na boca e ao ser mastigada a membrana se rompe e libera o líquido de seu interior. O projeto aparece como uma alternativa engenhosa e econômica ao descarte de embalagens plásticas. Segundo seus criadores, ela pode ser feita com apenas dois centavos de dólares. "A realidade é que cada vez mais, quando bebemos água, jogamos fora uma garrafa de plástico", disse ao $s i$ te Fast CoExist (http://www.fastco.com/), o designer Rodrigo García. "E oitenta por cento deles não são reciclados. Esse consumismo reflete a sociedade em que vivemos", ele completa. O projeto foi o vencedor do segundo concurso anual Lexus Design Award. 


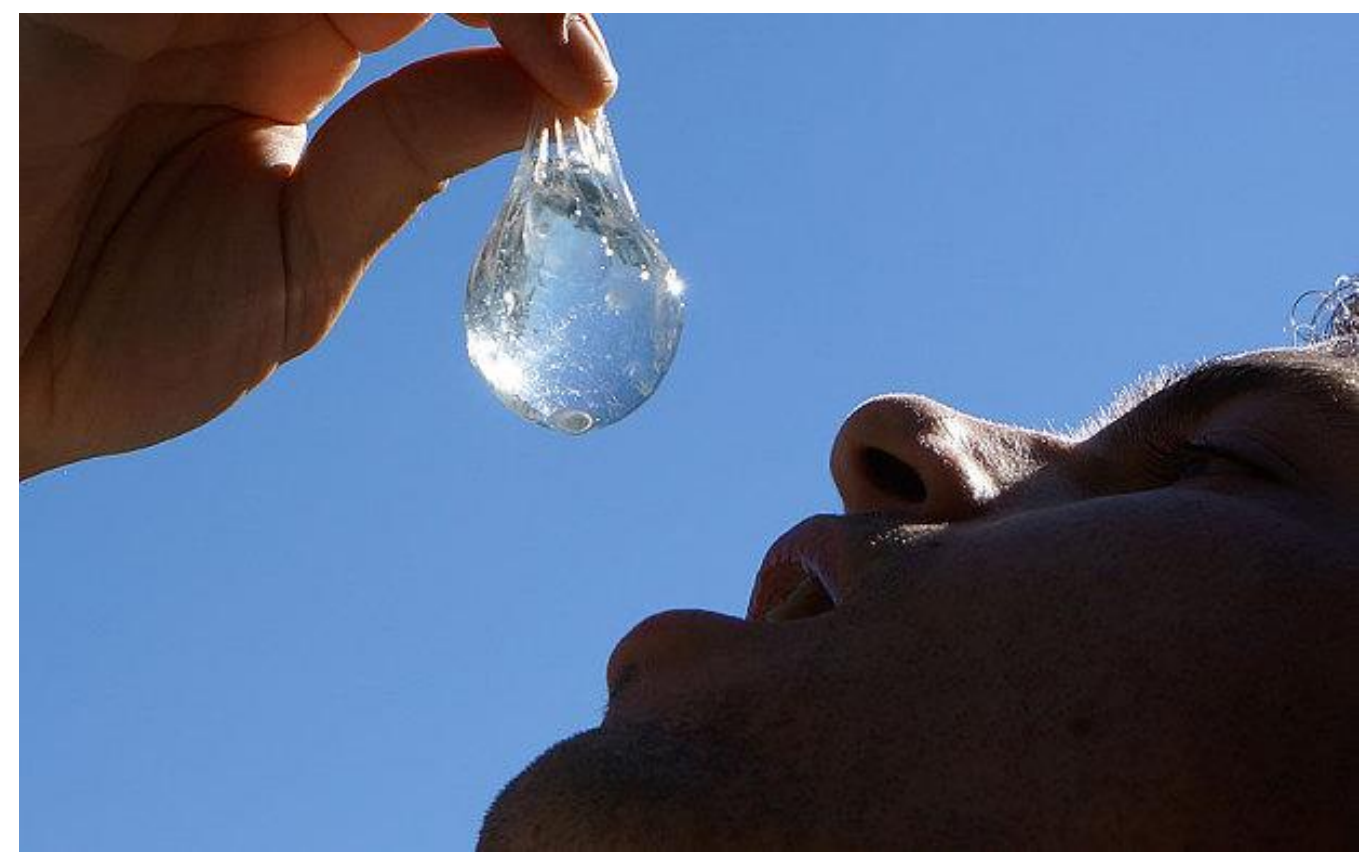

Figura 17 - Imagem do produto Ooho.

Disponível em: <http://www.telegraph.co.uk/news/newstopics/howaboutthat/11095793/Drunkyour-water-Now-eat-the-bottle-it-came-in.html>. Acesso em: 20 nov. 2014.

Esse capítulo apresentou um breve panorama histórico de uma nova ciência chamada Biomimética e explicitou por meio de diversos exemplos a sua incrível evolução nos últimos anos, tanto no volume de pesquisa científica acadêmica, quanto na implantação de soluções inovadoras e revolucionárias, provando ser uma abordagem de sucesso.

No próximo capítulo dissertaremos sobre as metodologias, ferramentas e técnicas que apoiam, orientam e estimulam a prática do Design Biomimético. 


\title{
3.
}

\section{O processo de Design Biomimético}

O crescimento de movimentos ligados ao Design Biomimético está relacionado ao reconhecimento por parte de projetistas, designers, engenheiros e arquitetos, de que a natureza pode inspirar inovações humanas. Em seu livro Biomimética - Inovação Inspirada pela Natureza, 2003, Janine Benyus explica:

\begin{abstract}
Nessas páginas, você conhecerá homens e mulheres que estão estudando as obrasprimas da natureza - fotossíntese, automontagem, seleção natural, ecossistemas auto-sustentáveis, olhos, ouvidos, peles, conchas, neurônios, terapias naturais e outras coisas mais -, as quais eles copiam e usam para criar processos para solucionar nossos problemas. Eu chamo essa busca de Biomimética - a imitação consciente da genialidade da vida. Inovação inspirada pela natureza. (BENYUS, 2003, p. 10).
\end{abstract}

“Biomimética é a realização de aplicações técnicas baseadas nos insights resultantes de fundamentos da investigação biológica”. (SPECK \& SPECK, 2008, pg.3).

Buscar inspiração na natureza para solucionar problemas e projetar equipamentos, construções e produtos é uma prática muito antiga, "mas o seu estudo sistemático visando o desenvolvimento de novos produtos é relativamente recente. Termos como Biônica e Biomimética foram cunhados apenas na década de 1960". (SALGUEIREDO, 2013, p.21).

Para que a prática do design inspirado na natureza seja adotado por mais projetistas e implementado em organizações empresariais de forma sistemática e consistente, são necessários métodos que ampliem o conhecimento biológico, apoiem a transferência desse conhecimento para a solução de problemas, e facilitem o uso de analogias com a natureza para gerar ideias e criar valor.

Este capítulo descreve alguns métodos desenvolvidos para apoiar, orientar e estimular a prática sistemática e a gestão da Biomimética no processo de Design.

$\mathrm{Na}$ revisão bibliográfica realizada para essa pesquisa, verificou-se que os pesquisadores mais citados e reconhecidos no campo metodológico da Biomimética, são: 
- Speck \& Speck (2008): definiram e testaram, em diversos projetos de Pesquisa e Desenvolvimento (P\&D), uma metodologia de fazer Biomimética que se caracteriza por duas diferentes abordagens: "processo de baixo para cima" e "processo de cima para baixo";

- Michael Helms, Swaroop S. Vattam e Ashok K. Goel (2009), pesquisadores do Design Intelligence Lab da School of Interactive Computing \& The Center for Biologically Inspired Design, conduziram em 2006 um estudo, no contexto de um curso introdutório interdisciplinar sobre projeto de engenharia biologicamente inspirada, no Georgia Institute of Technology, que concluiu: 1) designers utilizam dois pontos de partida distintos para o projeto biologicamente inspirado; 2) padrões regulares de prática emergem no design de inspiração biológica; e 3) certos erros ocorrem regularmente no processo de design.

- Janine M. Benyus (2003), cientista americana e autora do livro: Biomimética - Inovação Inspirada pela Natureza - vem liderando o movimento crescente de projeto biologicamente inspirado, impulsionado pela necessidade de desenvolvimento sustentável. Benyus estruturou uma metodologia chamada "Lentes Biomiméticas para o Design" (Biomimicry Design Lens), que provêm uma nova maneira de ver o mundo e que resultam em um processo guiado para usar a genialidade da natureza e prol do design.

- Chakrabarti et al. (2005) desenvolveu o modelo SAPPhIRE e a ferramenta computacional IDEAINSPIRE, de apoio a designers, que fornece descrições das estruturas, comportamentos e funções de sistemas naturais e artificiais para inspirar novos espaços de solução para problemas de design de produto.

Os pesquisadores citados acima empenham esforços no sentido de sistematizar e desenvolver metodologias relacionadas à "busca, recuperação representação dos fenômenos biológicos para o projeto", - onde há integração de biólogos no processo de design, e ao desenvolvimento e uso de bases de dados que contêm os fenômenos biológicos.

A inteligência instalada na natureza está à nossa disposição e podemos aprender a imergir nesse conhecimento e usá-lo para solucionar problemas e inovar, como fizeram alguns de nossos antepassados. 


\section{1. Metodologias que apoiam o Design Biomimético}

Pesquisas de Speck \& Speck (2008) esclarecem que "Biomimética é a realização de aplicações técnicas baseadas nos insights resultantes de fundamentos da investigação biológica" (SPECK \& SPECK, 2008, pg.3) e que seu processo é essencialmente interdisciplinar e envolve biólogos, designers, engenheiros, químicos e físicos, que cooperam na busca de analogias e transferências entre a biologia e implementações técnicas. Speck \& Speck (2008, pg. 6) apontam duas direções no processo de Design Biomimético como um todo (dos conceitos iniciais ao desenvolvimento do produto): a abordagem "de baixo para cima" (bottom up), também chamada "orientada à solução" (solution driven), ou "impulsionada pela biologia" (biology push); e a abordagem "de cima para baixo" (top down), também chamada "orientada ao problema" (problem driven), ou "puxada pela tecnologia" (technology pull).

$\mathrm{Na}$ abordagem "de baixo para cima", ou "orientada à solução", o ponto de partida de uma pesquisa ou projeto é dado por biólogos, a partir da análise biomecânica, morfológica funcional e anatômica de um dado sistema biológico (biological insight). Em um próximo passo, análises quantitativas levam à compreensão detalhada de estruturas biológicas, formas e funções, para em seguida serem abstraídos, extraindo princípios descobertos a partir do modelo biológico, a fim de facilitar o entendimento por parte dos projetistas. Em seguida, os princípios extraídos são usados em projetos de produtos e implementados tecnicamente por engenheiros, designers, químicos, etc... (SPECK \& SPECK, 2008).

A abordagem "de cima para baixo", ou "orientada ao problema", começa com a definição, por parte de um engenheiro, de um problema técnico ou da necessidade de melhorias em um produto já existente, de tal maneira que permita uma busca por analogias biológicas. Nesse processo também é feita a abstração, caso existam, de dados biológicos disponíveis para solucionar o problema. É necessário que engenheiros e biólogos cooperem durante o processo, que começa com a definição precisa do problema técnico a ser resolvido. Em seguida, o biólogo procura exemplos na natureza que pareçam promissores para resolver o problema. Em geral são identificados vários exemplos que são discutidos entre os biólogos e engenheiros a fim de selecionar um ou dois que encaixem melhor como 
solução do problema técnico, para posterior análise e investigação experimental. Como no processo "de baixo para cima", parte-se para a abstração, onde separa-se as soluções encontradas a partir de seus exemplos naturais. $\mathrm{O}$ próximo passo na sequência de uma transferência bem sucedida de conhecimento, o engenheiro investiga o potencial para a execução técnica. Posteriormente, protótipos biomiméticos são produzidos e seu desempenho é testado. Se os testes forem bem sucedidos, o desenvolvimento é estendido para a produção industrial. (SPECK \& SPECK, 2008).

As abordagens "de baixo para cima" e "de cima para baixo" estão sintetizadas nos Quadro 1 e 2, abaixo.

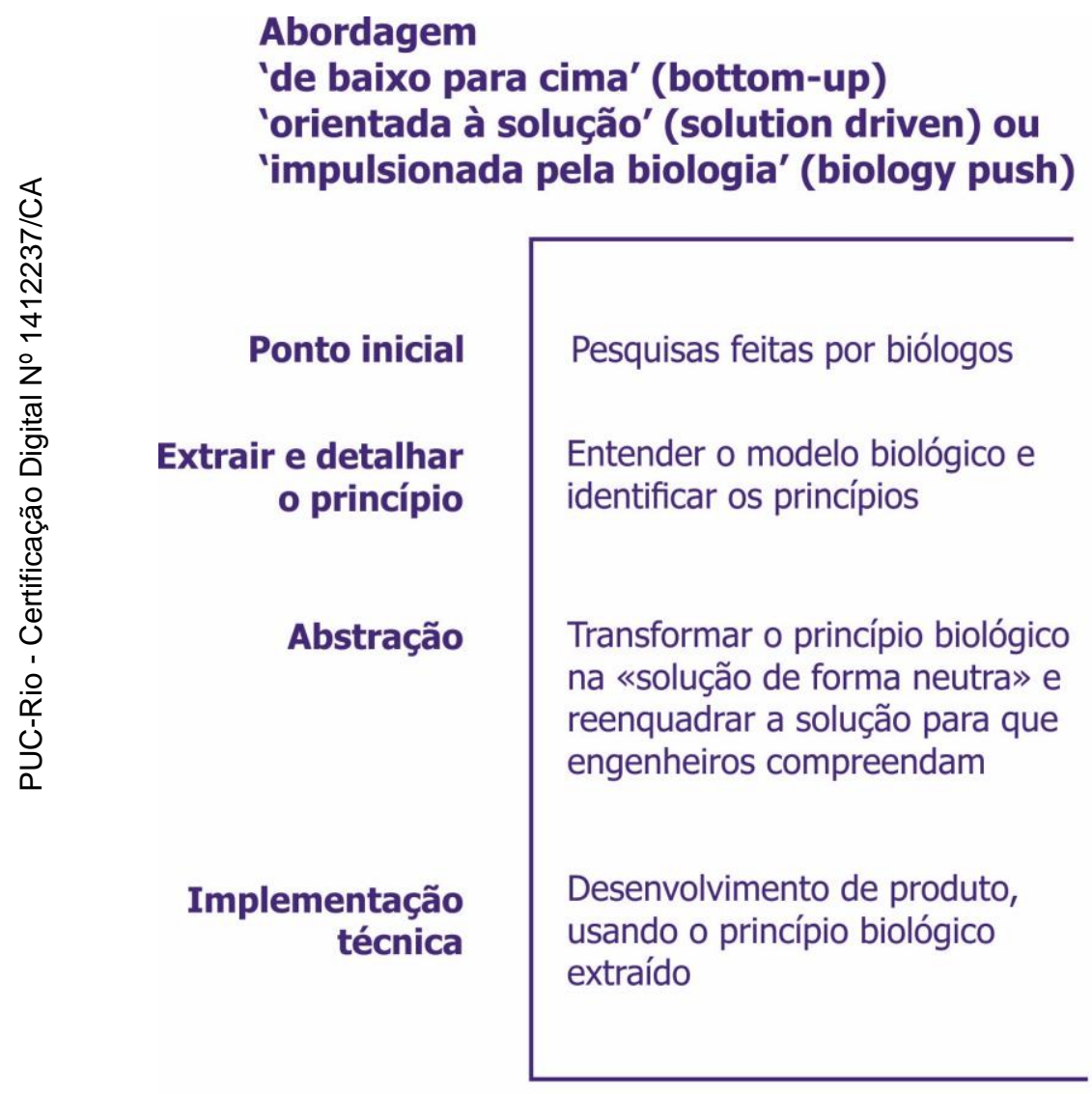

Quadro 1 - Quadro "de baixo para cima" adaptado do artigo "Process sequences in biomimetic research” (Speck \& Speck, 2008). 


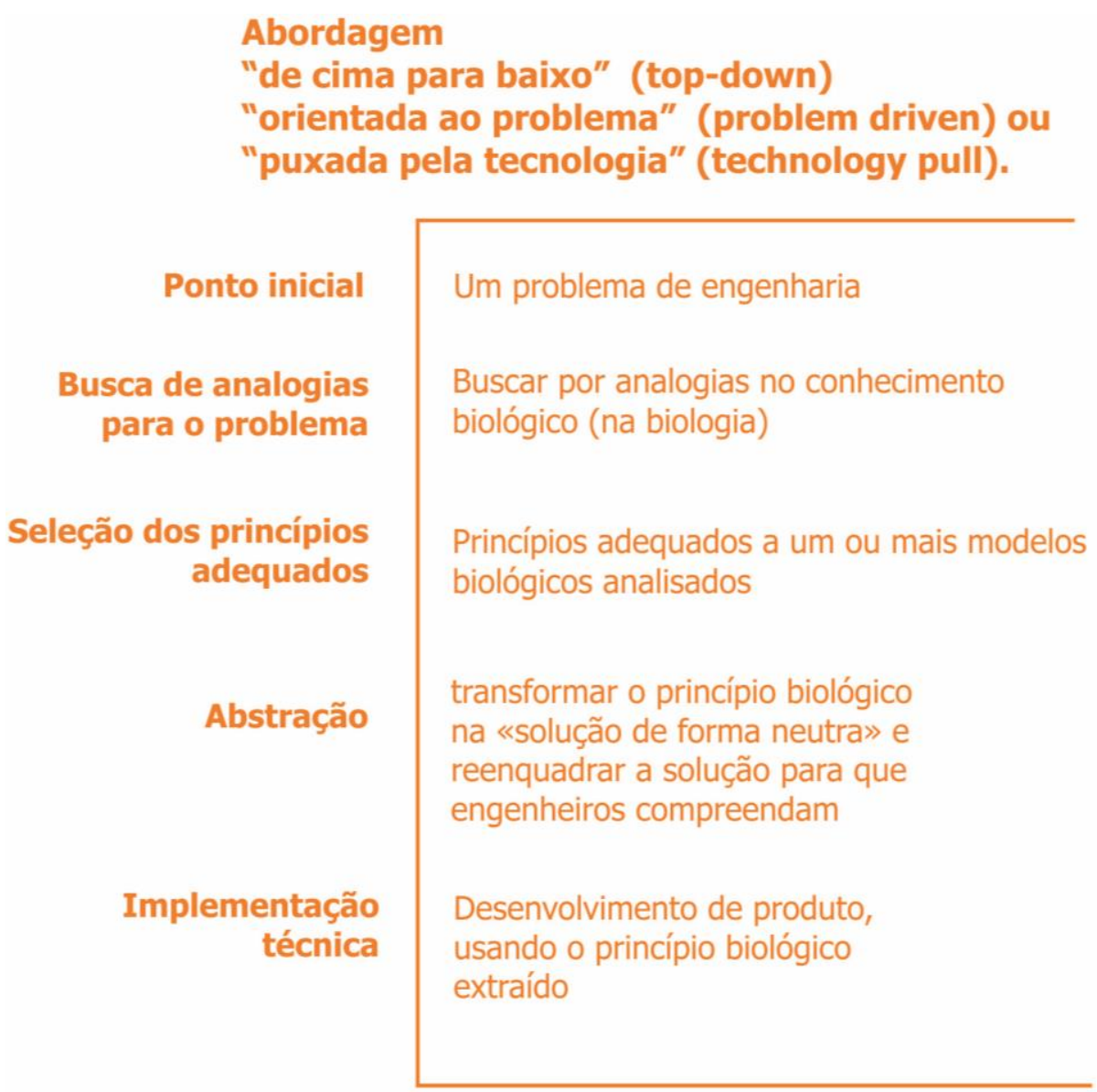

Quadro 2 - Quadro "de cima para baixo" adaptado do artigo "Process sequences in biomimetic research" (Speck \& Speck, 2008).

Os pesquisadores Michael Helms, Swaroop S. Vattam e Ashok K. Goel (2009) incluíram algumas etapas a mais nessas abordagens, quando conduziram um estudo no contexto de um curso introdutório interdisciplinar sobre projeto de engenharia biologicamente inspirada, no Georgia Institute of Technology, em 2006

Descreve-se, a seguir, as etapas do processo de design biologicamente inspirado - "de baixo para cima", ou orientado à solução (A); e "de cima para baixo", ou orientado ao problema (B), - estruturadas pelos pesquisadores (HELMS, et al., 2009, pg. 610-616):

\section{A. Processo de design biologicamente inspirado - "de baixo para cima", ou orientado à solução:}

Etapa 1: Identificação da solução biológica - designers começam com uma solução biológica particular. 
Etapa 2: Definição da solução biológica

Etapa 3: Extração do princípio biológico

Etapa 4: Reformular a solução. Neste caso, a resignificação força o designer a pensar em termos de como os seres humanos vêem utilidade na função biológica a ser alcançada.

Etapa 5: Busca do problema. Considerando que a pesquisa no domínio biológico é finita a algumas soluções biológicas documentadas, a busca do problema pode incluir a definição de problemas inteiramente novos. Isto é muito diferente da etapa de busca da solução no processo orientado ao problema.

Etapa 6: Definição do problema

Etapa 7: Aplicação do princípio

\section{B. Processo de design biologicamente inspirado - "de cima para baixo", ou orientado ao problema:}

Etapa 1: Definição do problema - designers buscam um problema e são orientados a defini-lo como função. Exemplo: o problema é a prevenção ao ataque de tubarões a surfistas e a função desejada é camuflar pranchas de surf.

Etapa 2: Reenquadrar o problema ou "biologizá-lo" - Para que os designers encontrem soluções análogas na biologia precisam redefinir os problemas em termos biológicos mais amplamente aplicáveis, muitas vezes sob a forma de uma pergunta como "Como soluções biológicas realizar a função xyz? Exemplo: em vez de "parar uma bala" a versão biologizada desta função seria "que características organismos têm que lhes permite prevenir, resistir e curar danos?"

Etapa 3: Busca da solução biológica - os instrutores do curso forneceram quatro técnicas para achar a solução biológica para o problema:

a) alterar restrições - se o problema é restrito, tal como "se refrescar", alterar as restrições ao aumentar o espaço de busca, por exemplo, para "termorregulação";

b) os campeões da adaptação - achar organismos ou sistemas que sobrevivem em casos extremos do problema que está sendo explorado. Exemplo: o problema é manter fresco, então, deve-se buscar animais que sobrevivem no deserto;

c) variação dentro de uma família de soluções - onde vários organismos têm enfrentado e resolvido o mesmo problema de uma maneira um pouco diferente; 
d) multifuncionalidade - encontre organismos ou sistemas com soluções únicas que resolvem vários problemas simultaneamente.

Etapa 4: Definir a solução biológica - designers, geralmente, identificam primeiro as estruturas e mecanismos superficiais a partir do sistema biológico que estava relacionado com a função reenquadrada. Por exemplo, a concha do abalone que tem a função de resistir ao impacto. Em seguida devem aprofundar na compreensão das interações complexas de materiais compósitos que são responsáveis por esse comportamento.

Etapa 5: Extração do princípio - depois que uma solução for bem compreendida, princípios importantes são extraídos em forma de solução neutra, ou seja, com menores restrições estruturais e ambientais. Exemplo: descrever os princípios do escudo do abalone como "interações entre proteínas flexíveis e depósitos de carbonato de cálcio hexagonais" pode restringir o projeto ao uso de proteínas, carbonato de cálcio, e hexágonos. Por outro lado, um "material composto de alternância de estruturas flexíveis e rígidas para resistir impacto", permite a possibilidade de utilizar arranjos de muitos tipos diferentes de material flexível e rígido.

Etapa 6: Aplicação do princípio - após o princípio ter sido extraído da solução biológica, designers transferem o princípio para o novo domínio.

Janine Benyus (Biomimicry 3.8) desenvolve, desde 1998, um método para entender as soluções da natureza. É chamado de "Lentes Biomiméticas" (Biomimicry Lens), por que provêm uma nova maneira de ver o mundo e que resultam em um processo guiado para usar a genialidade da natureza e prol do design.

As “Lentes Biomiméticas para o Design” (Biomimicry Design Lens), desenvolvidas por Benyus propõem naturalizar o ato de pedir conselhos à natureza em busca de inovações. São uma coleção de diagramas que visualmente representam os fundamentos da abordagem de design do Biomimicry 3.8. As Lentes: Elementos Essenciais (Essential Elements), Princípios da Vida (Life's Principals) e Pensamento Biomimético (Biomimicry Thinking) - ajudam a observar profundamente como a vida funciona e fornecem um quadro que orienta como utilizar, por meio de princípios éticos e testados, a genialidade da natureza para guiar projetos humanos.

A Lente "Elementos Essenciais" (Essential Elements) descreve os elementos essenciais da metodologia; - Ética (ethos): a essência de nossa ética, nossas inten- 
ções e filosofia de praticar o design biologicamente inspirado. Ethos representa nosso respeito, responsabilidade e gratidão às espécies e à terra; - Reconectar (Reconnect): reforça o entendimento de que apesar de parecermos separados, pessoas e natureza estão profundamente ligados. Nós somos natureza e reconectar é uma prática que explora e aprofunda esse relacionamento; - Emular (Emulate): esse elemento trás os princípios, padrões, estratégias e funções encontradas na natureza para informar o design. Esses Elementos Essenciais (Figura 19) combinados configuram os fundamentos da Biomimética (Biomimicry).

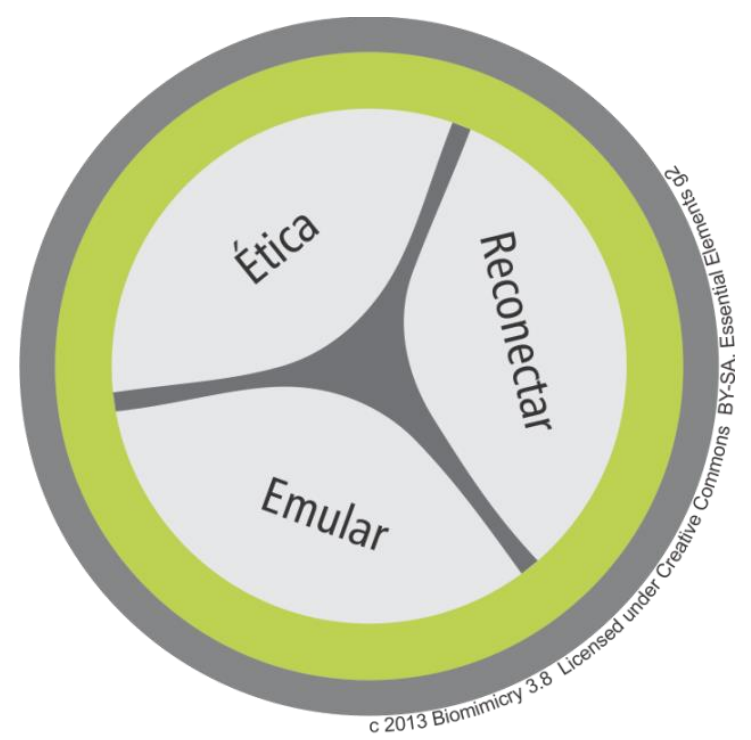

\section{ELEMENTOS ESSENCIAIS \\ Biomimicry Design Lens \\ Biomimicry.net AskNature.org}

Figura 18 - Lente biomimética Elementos Essenciais. Disponível em: <http://biomimicry.net/about/biomimicry>. Acesso em 21 nov. 2014.

A Lente "Princípios da Vida" (Life Principals) (Figura 20) aborda as lições de design da natureza, mostrando que a "vida" construiu uma série de estratégias e vem evoluindo há 3.8 bilhões de anos, sob as condições de funcionamento da terra (Luz do sol, água e gravidade; não-equilíbrio dinâmico; limites e fronteiras; processos cíclicos), com o objetivo de criar condições úteis à "vida". Essas estratégias devem ser usadas, segundo a metodologia do Biomimicry 3.8, como um checklist para orientar projetos humanos. São elas: evoluir para sobreviver; adaptar às condições de mudança; ser localmente sintonizado e responsável; usar química amiga da vida; ser eficiente no uso de recursos (material e energia) e integrar desenvolvimento com crescimento. 


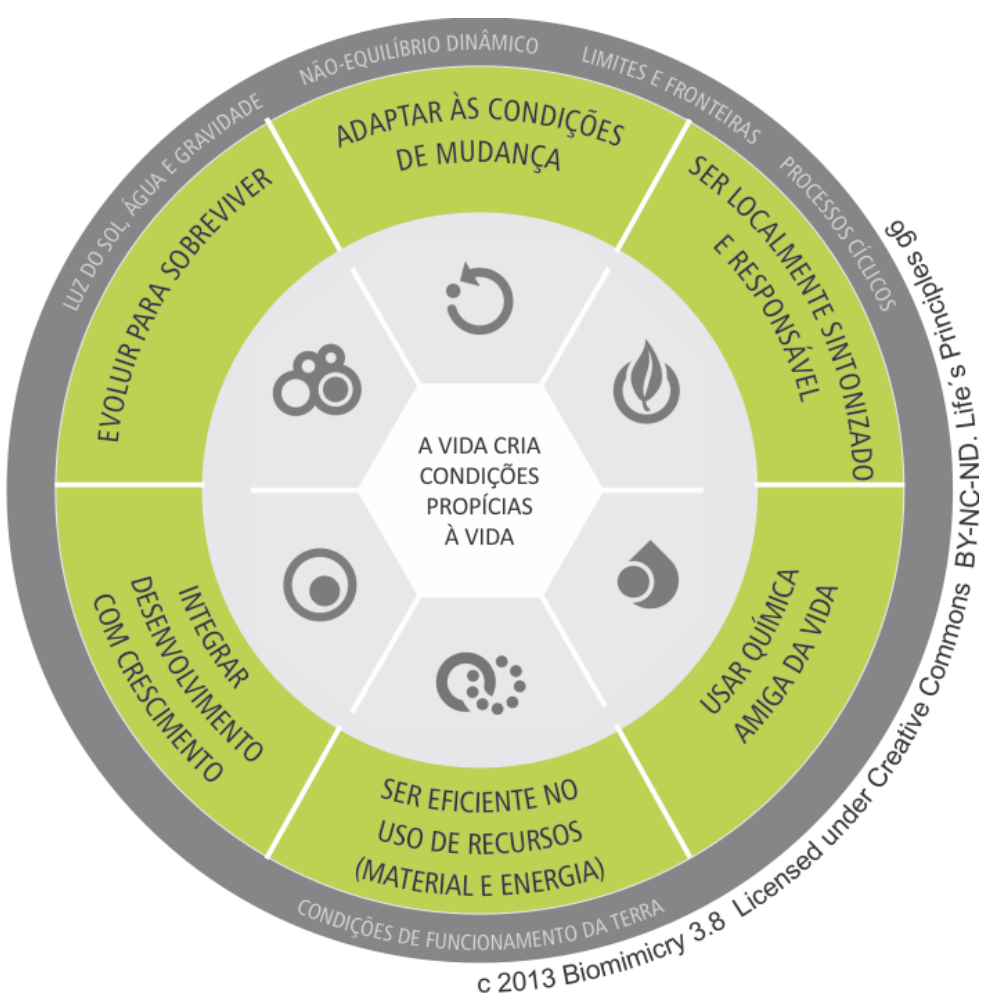

\section{PRINCÍPIOS DA VIDA}

\section{Biomimicry Design Lens}

Biomimicry.net AskNature.org

Figura 19 - Lente Princípios da Vida - imagem disponível em http://biomimicry.net/about/biomimicry acessado em 21/11/2014

A Lente "Pensamento Biomimético" (Biomimicry Thinking) provê um contexto no qual, onde, quando, como e por que a Biomimética encaixa em processos de design, e tem o objetivo auxiliar as pessoas a usá-la ao projetarem qualquer coisa.

São quatro áreas de geração de valor para o processo de design: Definindo o escopo (scoping), Descobrindo (discovering), Criando (creating) e Avaliando (evaluating). Segundo Benyus (2007), seguindo esses passos o designer tem uma garantia de sucesso na integração dos princípios da vida no design.

Pode-se seguir duas abordagens no Pensamento Biomimético.

A primeira: Desafio para a biologia (Challenge to biology) - é útil para cenários onde o problema está bem definido e se está procurando insights biológicos para solucioná-lo. Deve ser aplicada em um ambiente "controlado" como uma sala de aula. (Figura 21). 


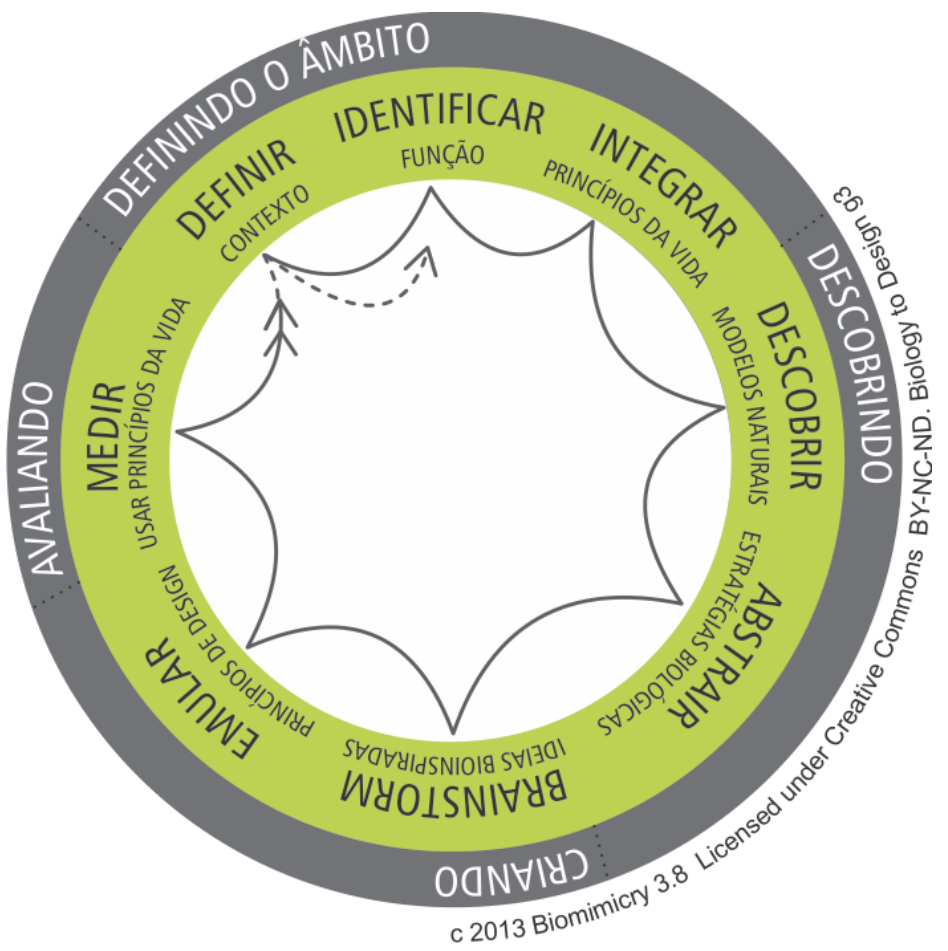

Figura 20 - Lente "Desafio para Biologia"

Diponível em: <http://biomimicry.net/about/biomimicry> Acesso em: 21 nov.2014.

Cada uma das quatro áreas de geração de valor possui atividades a serem realizadas, como detalhado, abaixo: (Biomimicry 3.8).

Definir contexto: Defina o problema e suas condições operacionais;

Identificar função: Determine as funções chave as quais o design deve atender. O que ele precisa fazer?;

Integrar princípios da vida: Comprometa-se a incorporar os princípios da vida nos requerimentos de design;

Descobrir modelos naturais: Ache organismos ou ecosistemas que tenham evoluído estratégias para resolver às funções desejadas;

Abstrair estratégias biológicas: Determine o mecanismo por trás das estratégias dos organismos e ecosistemas e traduza-os em um princípio de design. Dica: remova referências biológicas;

Brainstorm ideias bioinspiradas: Pense em ideias de como combinar contexto, função e princípios de design, para resolver um problema;

Emular princípios de design: Aprimore as melhores ideias de seu brainstorm e desenvolva um conceito de design;

Considere aspectos de escala, e caso vá além da forma, considere também processos e ecosistemas; 
Medir, usando princípios da vida: Avalie seu design usando os princípios da vida como um checklist.

A segunda abordagem é: Biologia para projetar (Biology to design). Essa abordagem é mais apropriada quando se tem um insight biológico que você quer manifestar em um design. A ser aplicado com inventores, empreendedores e profissionais interessados na interdisciplinaridade. (Figura 22).

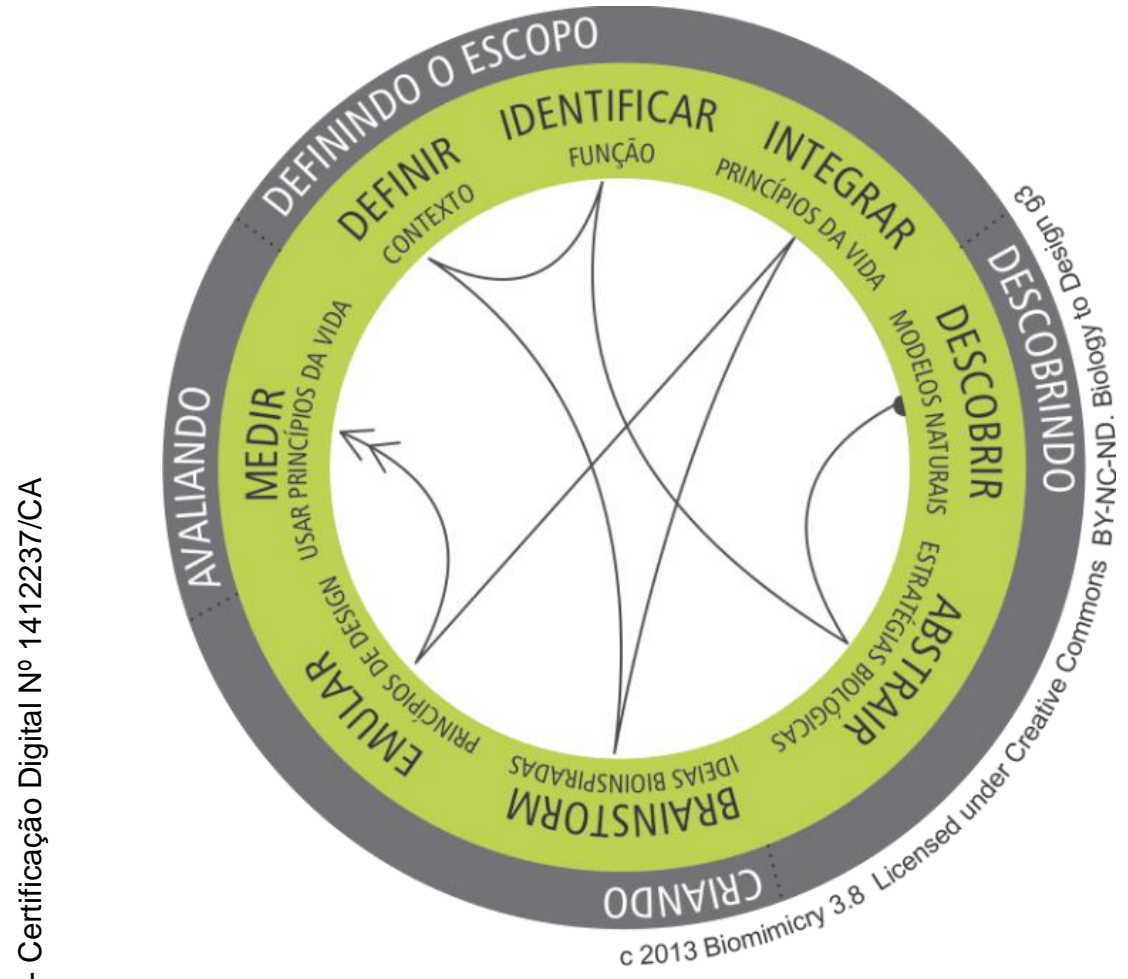

Figura 21 - Lente "Biologia para projetar".

Diponível em: <http://biomimicry.net/about/biomimicry>. Acesso em: 21 nov.2014.

Cada uma das quatro áreas de geração de valor possui atividades a serem realizadas, como detalhado, abaixo: (Biomimicry 3.8).

Descobrir modelos naturais: Ache um organismo ou ecosistema inspirador e aprenda sobre suas estratégicas únicas para sobreviver;

Abstrair estratégias biológicas: Determine o mecanismo por trás das estratégias dos organismos e ecosistemas e traduza-os em um princípio de design. Dica: remova referências biológicas;

Identificar função: Usando a estratégia e seu princípio de design como guia, defina qual a necessidade funcional está sendo atendida. Dica: a função deve ser a mesma para ambos; 
Definir contexto: Especifique as circunstâncias onde essa função é desejada. O que necessita fazer o que esse organismo, ou ecossistema está fazendo?;

Brainstorm ideias bioinspiradas: Pense em ideias de como combinar contexto, função e princípios de design, para resolver um problema;

Integrar princípios da vida: Ao considerar suas ideias esteja certo de incorporar os princípios da vida na solução;

Emular princípios de design: Aprimore as melhores ideias de seu brainstorm e desenvolva um conceito de design. Considere aspectos de escala, e caso vá além da forma, considere também processos e ecossistemas;

Medir, usando princípios da vida: Avalie seu design usando os princípios da vida como um checklist.

\section{2. \\ Bases de dados que dão suporte ao Design Biomimético}

Um caminho óbvio para identificar potenciais analogias biológicas para solução de projetos humanos é consultar biólogos. A vantagem de consultá-los é que o engenheiro, geralmente sem treinamento em biologia, não tem de procurar e interpretar a relevância e potencial de aplicação de informações que podem ser desconhecidos. A desvantagem dessa abordagem é que é preciso ter acesso aos biólogos. Além disso, os biólogos podem ser inclinados para suas áreas de especialização, em vez de objetivamente recordar e apresentar uma variedade de fenômenos como potenciais analogias. Uma abordagem para resolver as limitações de consultar biólogos diretamente é a tentativa de capturar os seus conhecimentos em um banco de dados. (Shu, 2011).

O Biomimicry 3.8, coordenado por Benyus, criou uma das mais importantes bases de dados on-line de fenômenos biológicos, a fim de dar suporte a projetos biomiméticos: o AskNature (www.asknature.org). Nessa base de dados (Figura 23), informações biológicas de grupos, subgrupos e funções estão estruturadas. Perguntas podem ser feitas pelo usuário, começando com: "Como a natureza..." (ex.: como a natureza protege?). Também é possível pesquisar pelo fenômeno biológico: Ex: fotossíntese, flor-de-lótus. As bases de dados dependem da entrada e atualização constante de informações e nem sempre são fáceis de consultar. 


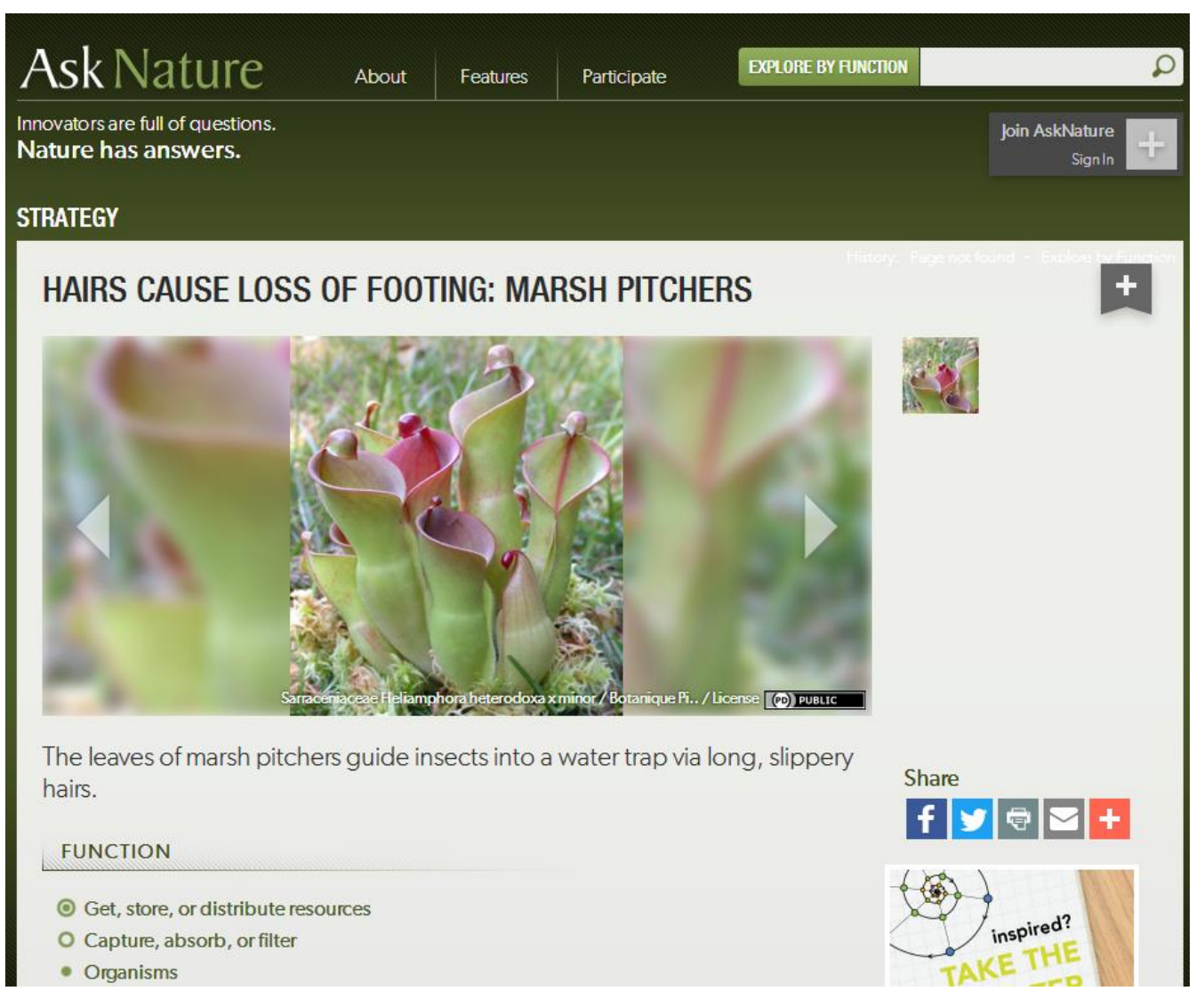

Figura 22 - Imagem do site www.asknature.org

Materiais didáticos, tanto para educação básica como para formação de especialistas em Biomimética, também podem ser baixados on-line. (Figura 24).

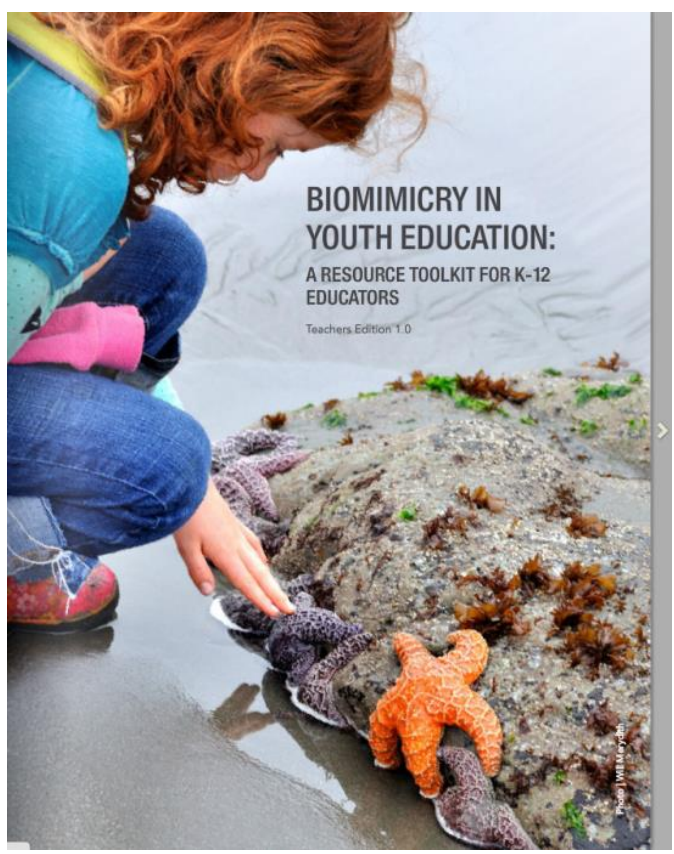

Figura 23 - Plataforma didática on-line acessado em 8/11/2015 
Chakrabarti et al. (2005) desenvolveu o modelo SAPPhIRE e a ferramenta computacional IDEAINSPIRE, com o objetivo de auxiliar designers a inovar, sistematizando a exploração e busca de soluções análogas nos mundos naturais e artificiais. Trata-se de duas bases de dados integradas: um banco de dados de sistemas naturais, com cerca de cem entradas de domínios de plantas e animais; e outro banco de dados de sistemas mecânicos artificiais (ex., aspiradores de pó, embreagens, etc.). Ambas contém informações sobre funções, comportamentos e estruturas de organismos.

O IDEAINSPIRE pode ser utilizado em dois modos diferentes: Quando um designer está pronto para resolver um problema bem definido, e quando está tentando resolver um problema não tão bem definido.

No primeiro modo, o designer pode definir diretamente o problema, usando verbo e substantivo (por exemplo: permitir que pessoas deficientes dos membros superiores comam sozinhas). O sistema buscará e apresentará soluções analógicas relevantes em sistemas naturais e artificiais, a partir dos quais o designer vai gerar ideias para a solução do problema. (Chakrabarti et al., 2005).

No segundo modo, o designer tem um problema não tão bem definido, como, por exemplo, "de movimento". Ele vai explorar as bases de dados em busca de informações sobre movimentos de vários tipos; tanto com relação ao meio em que eles ocorrem, ou seja, ar, água, terra, espaço vertical, deserto, etc..,, quanto da maneira com que ocorrem: saltando, andando, rastejando, etc... A informação transmitida contém detalhes sobre a função, comportamento e estrutura de diversos organismos, tanto naturais quanto artificiais. Em seguida, o designer se interessa por algum movimento, e extrai ideias para uma possível aplicação. (Chakrabarti et al., 2005).

Usando estes modos de interagir com o software IDEAINSPIRE, o designer pode simplesmente procurar as entradas para a estimulação aleatória ou sistematicamente pesquisá-los com fins específicos. O objetivo da busca é apoiar o raciocínio analógico em vários níveis de abstração. (Chakrabarti et al., 2005). 
Esse capítulo apresentou alguns métodos usados para apoiar, orientar e estimular a prática sistemática e a gestão da Biomimética no processo de design. Pesquisadores em todo mundo empenham esforços no sentido de sistematizar e desenvolver metodologias para facilitar o uso de analogias com a natureza para gerar ideias e criar valor. Entre eles: Speck \& Speck (2008), que definiram e testaram, em diversos projetos de Pesquisa e Desenvolvimento (P\&D), uma metodologia de fazer Biomimética que se caracteriza por duas diferentes abordagens: "processo de baixo para cima" e "processo de cima para baixo"; Michael Helms, Swaroop S. Vattam e Ashok K. Goel (2009), que incluíram algumas etapas a mais nessas abordagens, quando conduziram um estudo no contexto de um curso introdutório interdisciplinar sobre projeto de engenharia biologicamente inspirada, no Georgia Institute of Technology; Janine M. Benyus (2003), que estruturou uma metodologia chamada "Lentes Biomiméticas para o Design" (Biomimicry Design Lens), que provêm uma nova maneira de ver o mundo e que resultam em um processo guiado para usar a genialidade da natureza e prol do design; e Chakrabarti et al. (2005) que desenvolveu o modelo SAPPhIRE e a ferramenta computacional IDEAINSPIRE, de apoio a designers, que fornece descrições das estruturas, comportamentos e funções de sistemas naturais e artificiais para inspirar novos espaços de solução para problemas de design de produto.

As metodologias e bases de dados apresentadas neste capítulo podem ser usadas para resolver problemas complexos por pesquisadores de diversas áreas, desde design, engenharia até inteligência artificial (AI). Elas apoiam e estimulam analogias biológicas (Biomimética) e sistematizam a transferência de informação e significado de um sujeito particular (fonte: natureza), para outro sujeito particular (alvo: produtos e serviços). Ao utilizá-las o designer pode adquirir uma ampla gama de possibilidades inventivas e estratégias, pois aproxima conhecimentos interdisciplinares, que em princípio não estavam relacionados, como biologia e design, e isso gera maior possibilidade de soluções originais que estabelecem novos paradigmas para resolver problemas e desafios enfrentados pelo homem. 


\section{4. \\ Experimentos Biomiméticos para o Design de Embalagem}

A busca por inspiração na natureza para solucionar problemas complexos estimulou áreas de conhecimento transdisciplinares, entre elas a Biomimética, que explora o uso de analogias biológicas na atividade de projetar. Observar como a natureza protege, acomoda, transporta, comunica e recicla, inspira soluções sustentáveis de alto impacto para embalagens porque abre uma ampla gama de possibilidades inventivas ao homem. O designer pode e deve apropriar-se desses princípios de forma estratégica para lançar-se à criação de embalagens inovadoras.

As novas tecnologias digitais estão provocando mudanças sísmicas nas economias mundiais. Elas oferecem uma nova forma de aproximação e abordagem para lidar com a complexidade dos dias atuais, pois permitem comunicação ágil em rede, visualização e análise de dados, mudança de modelo fabril e de manufatura, entre outros. (MIT Technology Review, 2015).

A presente pesquisa tem uma característica exploratória, voltada a investigar se abordagens de pensar e projetar embalagens por meio de analogias entre biologia e design (Biomimética) são potencializadas por novas tecnologias digitais (especialmente microtomografia e impressão 3D). Tem também, uma característica experimental, objetivando estimular a criação e materialização de conceitos inovadores Biomiméticos, para embalagem de alimentos.

Os métodos de pesquisa escolhidos para essa investigação e Experimentação foram: (1) pesquisa bibliográfica sobre Biomimética, processo de design e embalagens (em livros, artigos, internet; principalmente duas bases de dados: a ISI Web of Science e a Science Direct, ambas por sua abrangência e qualidade; (2) pesquisa de campo em ambientes naturais, principalmente no Jardim Botânico do Rio de Janeiro, para observações intuitivas sobre elementos da natureza (dados primários), entrevistas com biólogos e biomimeticistas, para absorver seu processo de trabalho e adquirir experiência; (3) pesquisas em bancos de dados biológicos 
(principalmente Asknature ${ }^{4}$ ), que proporcionam conhecimentos abrangentes sobre a vida na terra e que auxiliam o entendimento das estratégias da natureza; (4) experimentação baseada na abordagem metodológica Biomimicry Design Lens (Lentes Biomiméticas), especialmente o modelo Biology to design (Biologia para Projetar) do Biomimicry 3.8 (2013).

Cabe destacar que a experimentação foi estruturada em dois momentos; visando avaliar a influência do uso de novas tecnologias digitais: Experimentação A (sem uso de novas tecnologias digitais), e Experimentação B (com uso de novas tecnologias digitais).

A Experimentação A abrangeu as seguintes Etapas: Descobrir modelos naturais (A1); Selecionar organismo inspirador (A2); Abstrair estratégias biológicas (A3); Identificar função e definir contexto (A4); Brainstorm ideias bioinspiradas (A5).

Como a Experimentação B também foi realizada a partir do mesmo organismo inspirador, portanto, não foi necessário repetir as Etapas de descoberta de modelos naturais e seleção do organismo inspirador. A Experimentação B, portanto, abrangeu as seguintes Etapas: Abstrair estratégias biológicas (B1); Identificar função e definir contexto (B2); Brainstorm 1 - primeiras ideias bioinspiradas (B3); Emular conceitos de design do brainstorm 1 (B4); Brainstorm 2 - novas ideias bioinspiradas (B5); Emular conceitos de design do brainstorm 2 (B6); Explorar e validar o conceito de design mais promissor para inovação de embalagem bioinspirada (B7).

A opção por fazer a experimentação descrita nesse capítulo, baseada nas Lentes Biomiméticas do Biomimicry 3.8 (2013), deve-se à credibilidade de sua principal pesquisadora e dirigente, Janine Benyus, hoje uma referência no uso da Biomimética no mundo todo. O Biomimicry 3.8 mantém diversas plataformas para disseminar a importância da inovação inspirada na natureza: livros, vídeos, bases de dados on-line, sites (www.biomimicry.net e www.asknature.org), e produz diversos materiais didáticos, tanto para educação básica como para formação de especialistas em Biomimética. Além disto, presta consultorias para pesquisadores na área e empresas que pretendem inovar utilizando a Biomimética, entre elas algumas reconhecidas empresas brasileiras.

${ }^{4}$ www.asknature.org 
As Lentes Biomiméticas propõem duas abordagens no Pensamento Biomimético.

A primeira, Challenge to Biology (Desafio para a Biologia), é útil para cenários onde o problema está bem definido e se está procurando insights biológicos para solucioná-lo. Deve ser aplicado em um ambiente "controlado" como uma sala de aula.

A segunda abordagem, Biology to Design (Biologia para projetar), é mais apropriada quando se tem um insight biológico que você quer manifestar em um design. A ser aplicada por inventores, empreendedores e profissionais interessados na interdisciplinaridade.

Portanto, acreditou-se ser a segunda abordagem a mais adequada como base metodológica para essa pesquisa, que tem uma forte característica experimental objetivando a criação e materialização de conceitos inovadores Biomiméticos, para embalagem de alimentos.

As abordagens descritas acima estão detalhadas no capítulo 3.1 dessa dissertação.

\section{1. \\ Experimento A}

O Experimento A foi realizado a partir do pensamento Biomimético, Biologia para Projetar (Biomimicry 3.8, 2007). Diferentemente da metodologia usada pelo Biomimicry 3.8, não integrou-se princípios da vida à solução, ou seja não fezse a avaliação das ideias bioinspiradas usando os princípios da vida como um chekcklist. Também não foram utilizadas novas tecnologias digitais, como microtomógrafo e impressora 3D.

As seguintes atividades foram executadas nas seguintes Etapas: (A1) Descobrir modelos naturais; (A2) selecionar organismo inspirador; (A3) abstrair estratégias biológicas; (A4) identificar função e definir contexto; (A5) brainstorm ideias bioinspiradas.

A Etapa A1 consistiu em descobrir um organismo, ou ecosistema inspirador, para aprender sobre suas estratégias para evoluir e sobreviver. Buscou-se inspiração na natureza, especialmente na Botânica, e seu reino das plantas: raiz, caule, folha, flor, fruto e semente, considerando-se os inúmeros exemplos de "boas embalagens" presentes no mesmo. As angiospermas foram estudadas e di- 
versos frutos foram coletados no arboreto do Jardim Botânico do Rio de Janeiro e em visitas guiadas por biólogos à Mata Atlântica, para observação e manuseio. Também foram consultadas bases de dados virtuais sobre biomimética e estudo de casos.

A Etapa A2 tratou de selecionar um organismo inspirador. Escolheu-se como inspiração o fruto do amendoim (pertencente à família das Angiospermas $\mathrm{Fa}$ baceae também conhecida como Leguminosae) por tratar-se de um fruto leguminoso com peculiaridades em relação a acomodação, proteção e conservação de suas sementes, entre elas: leveza, resistência, impermeabilidade, abertura facilitada e adaptabilidade a diferentes quantidades de sementes.

Em seguida, na Etapa A3, com o apoio de um biólogo e de uma análise morfológica, procurou-se abstrair as estratégias biológicas usadas pelo amendoim, para evoluir e sobreviver.

A Etapa A4 visou entender as funções do fruto do amendoim. Tratou-se de identificar uma característica, mecanismo, processo, que faz alguma coisa (uma função) para esse organismo. São as "coisas" que a estratégia faz para o organismo, e o contexto onde essa função é desejada.

Abstraídas as estratégias e definidas as funções do fruto do amendoim, geraram-se, por analogia, ideias para embalagens (Etapa A5).

\subsection{1. \\ Etapa A1: Descobrir modelos naturais}

A primeira etapa do Experimento A consistiu em descobrir um organismo, ou ecosistema inspirador, para aprender (sem uso de novas tecnologias) sobre suas estratégias para evoluir e sobreviver.

Buscou-se inspiração na natureza, especialmente na Botânica, e seu reino das plantas: raiz, caule, folha, flor, fruto e semente, considerando-se os inúmeros exemplos de "boas embalagens" presentes no mesmo.

As atividades dessa Etapa A1 consistiram em, após descoberto o organismo inspirador (reino das plantas), conhecer suas variadas estratégias quanto à proteção, acomodação, contenção, armazenagem, distribuição e transporte, a fim de posteriormente transferí-las, por analogia, para o design de embalagem. 
Para tanto, foi necessário acessar um espaço amplo de conhecimento na biologia (dados secundários), e também imergir na natureza (dados primários), observando e perguntando-se, por exemplo, como um determinado fruto faz para acomodar, proteger, distribuir e liberar suas sementes?

Realizou-se, portanto, nessa etapa A1: (A1.1) pesquisa bibliográfica; (A1.2) visitas a instituições de pesquisa biológica; (A1.3) entrevistas com biólogos; (A1.4) observações da natureza em parques, florestas, matas, etc... (A1.5) coleta de material biológico, tais como: flores, frutos, sementes; (A1.6) análise do material biológico, sem uso de novas tecnologias; (A1.7) pesquisa documental em bases de dados virtuais sobre biomimética e estudo de casos;

A pesquisa bibliográfica (A1.1) incluiu livros sobre biologia vegetal. Entre eles, os mais utilizados em nossa pesquisa foram: "Introdução à biologia vegetal", de Eurico Cabral de Oliveira (2008) e "Botânica: taxonomia, morfologia e reprodução dos angiospermae: chave para determinação das famílias" de Fernando Vieira Agarez (1994).

Buscou-se nessa literatura, informações científicas básicas sobre nossa área de inspiração: a Botânica, especialmente a classe das angiospermas: "plantas com flores e que também se caracterizam por darem às suas sementes uma proteção extra, encerrando-as em uma estrutura que chamamos técnicamente de fruto". (OLIVEIRA, 2008, pg 201).

Neste filo, também conhecido como Angiospermae, isto é, plantas que produzem sementes encerradas em uma urna, estão as plantas que dominam o ambiente terrestre há muitos milhões de anos, desde o final do Mesozóico. Os dados existentes indicam que as angiospermas surgiram há cerca de 130 milhões de anos, em um período da história da vida em que um número muito grande de espécies de plantas e animais desapareceram, talvez devido a mudanças muito rápidas das condições ambientais. (OLIVEIRA, 2008, pg. 2012).

O aparecimento das flores com frutos teve profundo impacto na vida de nosso planeta. Historicamente, os frutos são muito importantes para alimentação humana, uma vez que apresentam grande variação na natureza ao redor do mundo, são fontes de vitaminas, cálcio, ferro e fibras e são fáceis de cultivar. O cultivo de plantas, ou seja, o surgimento da agricultura, fez com que milhares de pessoas pudessem habitar e fixar-se em regiões onde poucos poderiam viver apenas da coleta e da caça. Com mais alimento disponível, comunidades cresceram e se de- 
senvolveram, dando origem às primeiras cidades e a inventos que aumentaram a produção de plantas, como a irrigação e a roda (OLIVEIRA, 2008).

As angiospermas constituem, como se sabe, a base da sobrevivência do homem e da maioria dos animais, sem falar de sua importância biológica fundamental na produção de oxigênio e de matéria orgânica, como produtores primários, juntamente com as algas que sustentam toda vida no planeta. Na realidade, mesmo antes do desenvolvimento da agricultura, o que deve ter ocorrido com alguns grupos humanos há cerca de 10 mil anos, o homem utilizava as plantas para a construção de seus abrigos, fibras para sua roupa, ferramentas e artefatos de caça, preparação de remédios, combustível para se aquecer e preparar suas refeições e, sobretudo, como alimento, como o faz ainda hoje. Dentre as plantas utilizadas como alimento destacam-se as gramíneas, fonte de cereais consumidos pelo homem há milênios. Podese generalizar dizendo que as grandes civilizações tiveram por base a produção e consumo do endosperma secundário das gramíneas, como aconteceu no Oriente com o arroz, na Europa com o trigo e centeio, na África com o millet e nas Américas com o milho. Além das gramíneas cabe destacar a importância da grande família das leguminosas, fonte de inúmeras sementes alimentícias, como os feijões e favas, sem falar de uma infinidade de itens alimentares oriundos de outras plantas que foram e continuam sendo imprescindíveis à vida do homem através dos tempos. (OLIVEIRA, 2008, pg. 212).

Dentre as características marcantes das angiospermas estão: (a) a transformação das folhas em apêndices florais (plantas floríferas); (b) e a presença de frutos em que ficam encerradas as sementes. (OLIVEIRA, 2008, pg. 213).

As flores são folhas modificadas e adaptadas para a reprodução sexuada dos angiospermas. "Uma flor completa possui pedicelo, receptáculo, cálice, corola, androceu e gineceu". (AGAREZ, 1994, pg. 34).

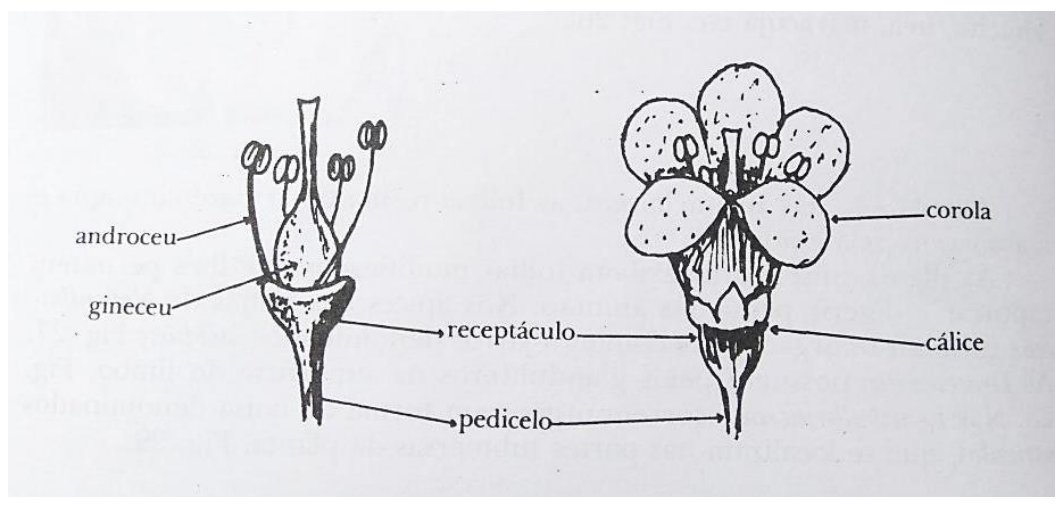

Figura 24 - Ilustração com as partes constituintes de uma flor completa (AGAREZ, 1994, pg 34).

A figura acima ilustra as partes internas e externas da flor. 
As partes externas dão sustentação e proteção aos aparelhos reprodutores, como nos explica Agarez (1994). São chamadas de: pedicelo (eixo de sustentação da flor); receptáculo (é uma dilatação do pedicelo); cálice (verticilo protetor, constituído por folhas modificadas chamadas sépalas); e corola (verticilo protetor interno, constituído por folhas modificadas chamadas pétalas).

As partes internas da flor, segundo Agarez (1994), são constituídas pelos aparelhos reprodutores, masculino e feminino. A maior parte das angiospermas tem os dois sexos na mesma planta e na mesma flor.

O androceu é o aparelho reprodutor masculino, constituído por órgãos denominados estames, constituídos de filete e antera, que é a parte fértil do estame, onde formam-se os grãos-de-pólen.

O gineceu é o "aparelho reprodutor feminino, formado por folhas modificadas, denominadas carpelos”. (AGAREZ, 1994, pg. 39). Quando completo o gineceu possui: ovário, estilete, estigma. O ovário é "formado pelos carpelos que se fecham delimitando cavidades denominadas lóculos, no interior das quais formam-se os óvulos". O estilete: "um filamento formado pelo prolongamento dos carpelos, sobre o qual fica o estigma, e finalmente, o estigma: "uma dilatação do estilete, rica em substâncias mucilaginosas que facilitam a fixação e a germinação dos grãos-de-pólen. (AGAREZ, 1994, pg. 39).

A figura abaixo ilustra os elementos básicos de uma flor, apresentando detalhes de suas partes internas, onde encontram-se os aparelhos reprodutores, masculino e feminino.

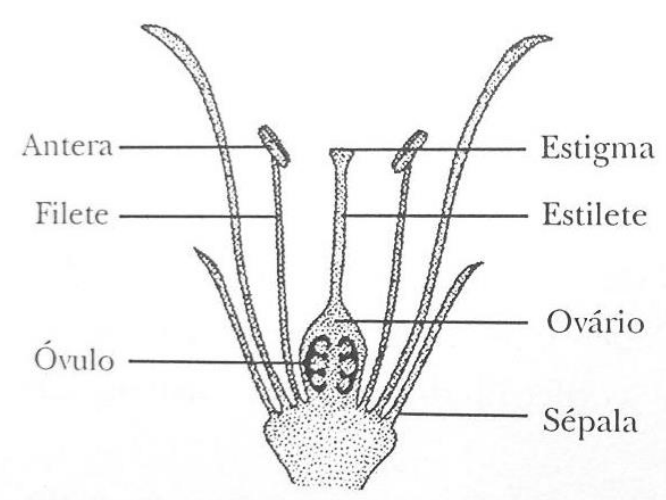

Figura 25 - Ilustração com esquema de um corte longitudinal de uma flor, mostrando seus elementos básicos reprodutores de uma flor de quaresmeira. (segundo F.K. Rawitscher, Elementos básicos de Botânica, apud OLIVEIRA, 2008, pg 214). 
A polinização nas angiospermas diz respeito ao transporte de grãos-de-pólen do aparelho reprodutor masculino (anteras), para o aparelho reprodutor feminino (estigma) para que haja a fecundação, formando o zigoto. Pode-se constatar pelo desenho esquemático abaixo, a transferência dos grãos-de-pólen presentes no saco polínico das anteras, para o estigma, configurando o início do processo de polinização.

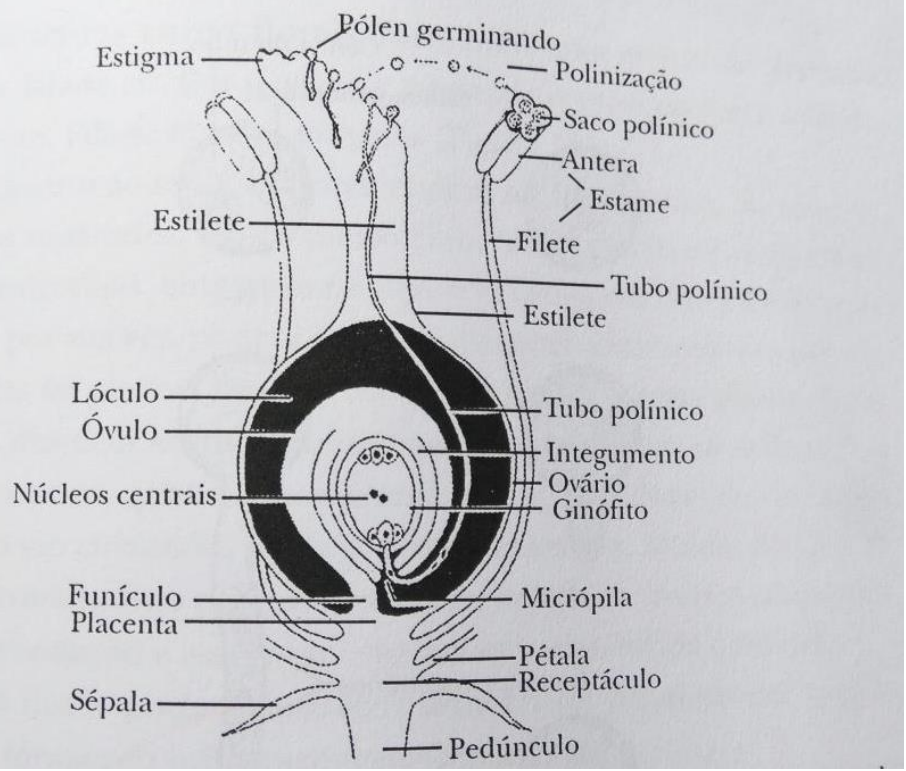

Figura 26 - Desenho esquemático do processo de fecundação de uma flor (segundo F.K. Rawitscher, Elementos básicos de Botânica, apud OLIVEIRA, 2008, pg 214).

Após descer pelo estigma, o pólen fecunda os óvulos, presentes no interior dos ovários, e estes produzem sementes que germinam em novas plantas (OLIVEIRA, 2008).

As sementes são protegidas enquanto amadurecem por uma estrutura presente em todas as angiospermas, chamada fruto. Os frutos são os ovários desenvolvidos da flor. Após a fecundação dos óvulos, o ovário (ou fruto) inicia um crescimento, acompanhado de uma modificação de seus tecidos provocada pela influência de hormônios vegetais, que interferem na estrutura, consistência, cores e sabores, dando origem ao fruto. "As paredes do ovário ao se desenvolverem sofrem profundas modificações e dão origem aos envoltórios do fruto: epicarpo, mesocarpo e endocarpo, cujo conjunto constitui o pericarpo". (AGAREZ, 1994, pg. 47).

Um fruto, portanto, é composto de duas partes principais: o pericarpo e as sementes. Como pode-se observar na ilustração abaixo, essas duas partes estão 
intimamente relacionadas: fisiologicamente, estruturalmente e ecologicamente. $\mathrm{O}$ pericarpo é a parte resultante do desenvolvimento da parede do ovário, já as sementes são provenientes dos óvulos fecundados.

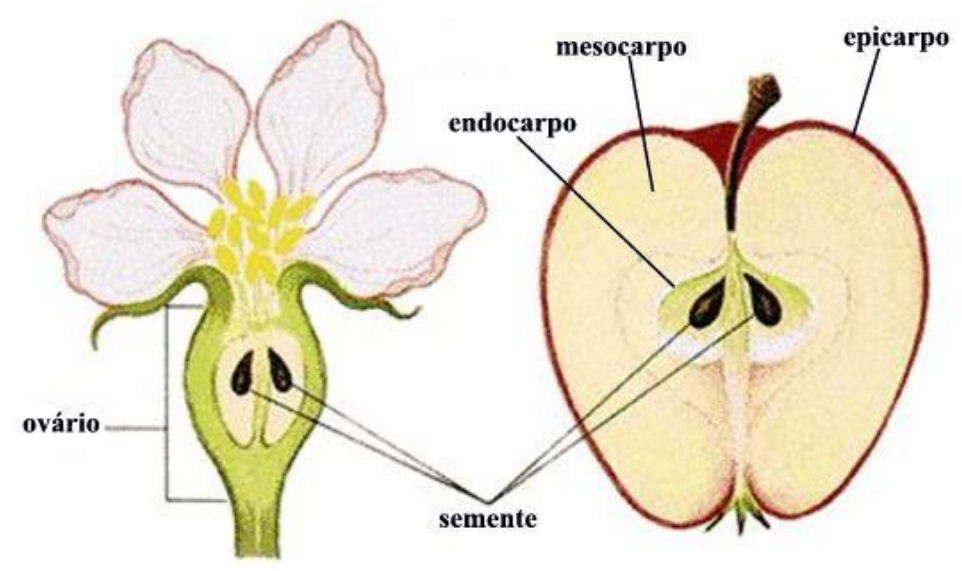

Figura 27 - Ilustração de sistema flor fruto e semente.

Os frutos mantêm-se fechados sobre as sementes até, pelo menos, o momento da maturação. Quando as sementes estão prontas para germinar, os frutos amadurecem, e podem abrir-se, liberando as sementes ao solo, ou tornam-se aptos a serem ingeridos por animais, que depositarão as sementes após estas passarem por seu aparelho digestivo (OLIVEIRA, 2008).

Como nos explica Oliveira (2008), além de proteger a semente, os frutos atuam na dispersão dessas estruturas, favorecendo a ocupação de outros ambientes pelas plantas. Vários mecanismos são conhecidos para assegurar a dispersão das sementes, alguns bastante complexos e nos quais as características dos frutos têm um papel muito importante.

A disseminação das sementes é passo fundamental na sobrevivência das espécies, e as mais incríveis adaptações são encontradas em algumas plantas. Nos casos mais simples os frutos secam e se rompem, às vezes por processos explosivos, atirando longe as sementes (...); em outros casos os frutos apresentam apêndices, como asas (...) ou pêlos que formam um pára-quedas e que lhes permite ser transportados a grandes distâncias pelo vento (anemocoria). Algumas apresentam mecanismos de flutuação e são transportadas pela água (hidrocória). Casos muito interessantes envolvem a participação de animais (zoocoria), incluindo-se aí quase todos os mecanismos zoológicos, como já mencionamos. Nesses casos, algumas sementes resistem ao processo de digestão e só germinam após passar pelo trato digestivo do animal, sendo eliminadas com as fezes. Este é um capítulo fascinante da biologia que envolve muitas vezes a participação de diferentes especialistas e sobre o qual existe muita informação publicada. (OLIVEIRA, 2008, pg. 222). 


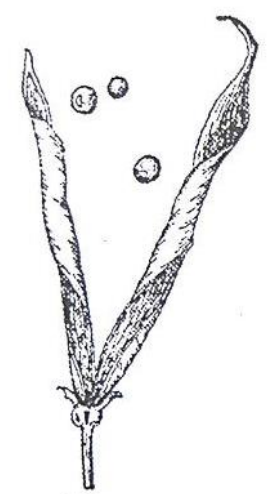

(a)

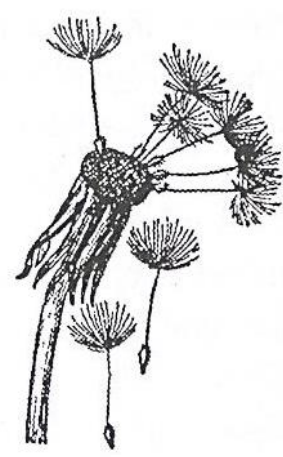

(b)

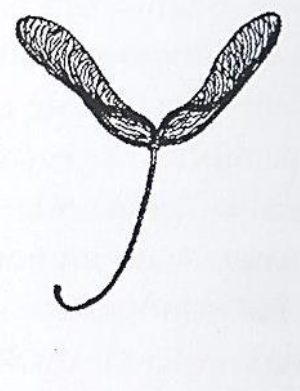

(c)

Figura 28 - Ilustração com exemplos de diferentes tipos de adaptações para disseminação de frutos e sementes: (a) disseminação de sementes por abertura "explosiva" do fruto; (b) e (c) disseminação pelo vento (segundo G.M. Smith et al., apud OLIVEIRA, 2008, pg 222).

Após descer pelo estigma, o pólen fecunda os óvulos, presentes no interior dos ovários, e estes produzem sementes que germinam em novas plantas (OLIVEIRA, 2008).

A semente representa um considerável progresso evolutivo para a vida fora da água, podendo ser descrita popularmente como 'um embrião pronto para viagem', pois encerra um organismo já completo, com todas as suas partes elementares prontas para se desenvolver. O embrião fica em estado quiescente, aguardando condições adequadas para iniciar seu crescimento, empacotado em um invólucro que lhe permite sobreviver às condições climáticas mais adversas, às quais não sobreviveria fora da semente. As reservas energéticas da semente lhe permitirão crescer até um estágio em que consiga produzir seu próprio alimento através da fotossíntese. Assim, a semente 'libertou' as plantas terrestres dos ambientes úmidos ribeirinhos e permitiu que as plantas conquistassem ambientes mais altos e mais secos. (OLIVEIRA, 2008, pg. 202)

As visitas à instituições de pesquisa biológica (A1.2) foram feitas principamente no Laboratório de Sementes (LS) do Jardim Botânico do Rio de Janeiro (JBRJ).

O LS tem capacidade técnica e instrumental para o desenvolvimento de pesquisas nas linhas de conservação e ecofisiologia de sementes, morfologia de sementes e plântulas e análise de crescimento vegetal, sendo responsável também pela atividade de rotina de colheita e beneficiamento de sementes de espécies nativas e exóticas em parceria com o Horto Florestal.

(Disponível em http://vm005.jbrj.gov.br/pesquisa/banco_sem/index.html). 
Abaixo, apresenta-se registro fotográfico do laboratório no dia de nossa primeira visita, em que pode-se ver os equipamentos utilizados na catalogação e preservação das diversas sementes estudadas e cultivadas pelo JBRJ.

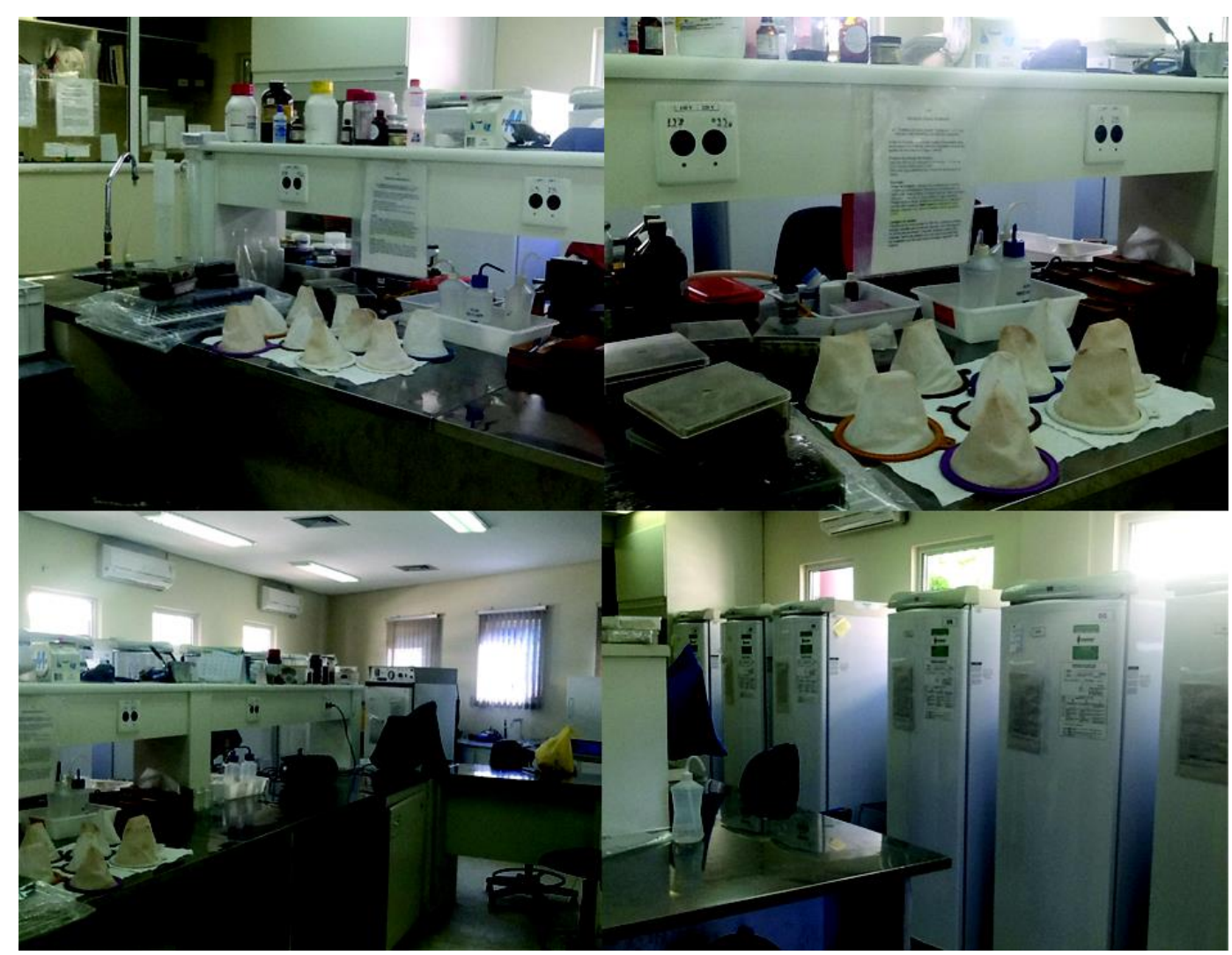

Figura 29 - Laboratório de Sementes Jardim Botânico RJ (LS), visitado em julho de 2015 (fotos da autora).

Nessas visitas ao LS, teve-se oportunidade de entrevistar biólogos da instituição (A1.3). Após uma série de entrevistas com a equipe do $\mathrm{JBRJ}^{5}$ no laboratório, visitou-se o arboreto do JBRJ para uma pesquisa de campo para observação da natureza (A1.4). O Dr. Claudio Nicoletti de Fraga foi responsável por acompanhar a visita com o intuito de identificar e coletar material biológico, tais como: flores, frutos, sementes, para nossa pesquisa (A1.5).

\footnotetext{
${ }^{5}$ A equipe que auxiliou a pesquisa é formada pelos seguintes pesquisadores do JBRJ: Dr. Antônio Carlos Silva de Andrade (Doutor em Ecologia e Recursos Naturais - ufscar (2001). Responsável pelas atividades científicas do LS-JBRJ); Dra. Marli Pires Morim (Doutora em Ciências Biológicasmodalidade Botânica- pelo Museu Nacional da Universidade Federal do Rio de Janeiro (2002). Pesquisadora Titular da Diretoria de Pesquisas do Instituto de Pesquisas Jardim Botânico do Rio de Janeiro (JBRJ)), e Dr. Claudio Nicoletti de Fraga (Doutor em Biologia Vegetal pela Universidade Federal de Minas gerais (2012). Atualmente é pesquisador do Instituto de Pesquisa Jardim Botânico do Rio de Janeiro com experiência na área de Botânica).
} 
Como pode-se constatar, nas fotos abaixo, coletou-se no arboreto do JBRJ, diversos frutos, entre eles: Urucum, Clusia Lanceolata, Gustavia Augusta.

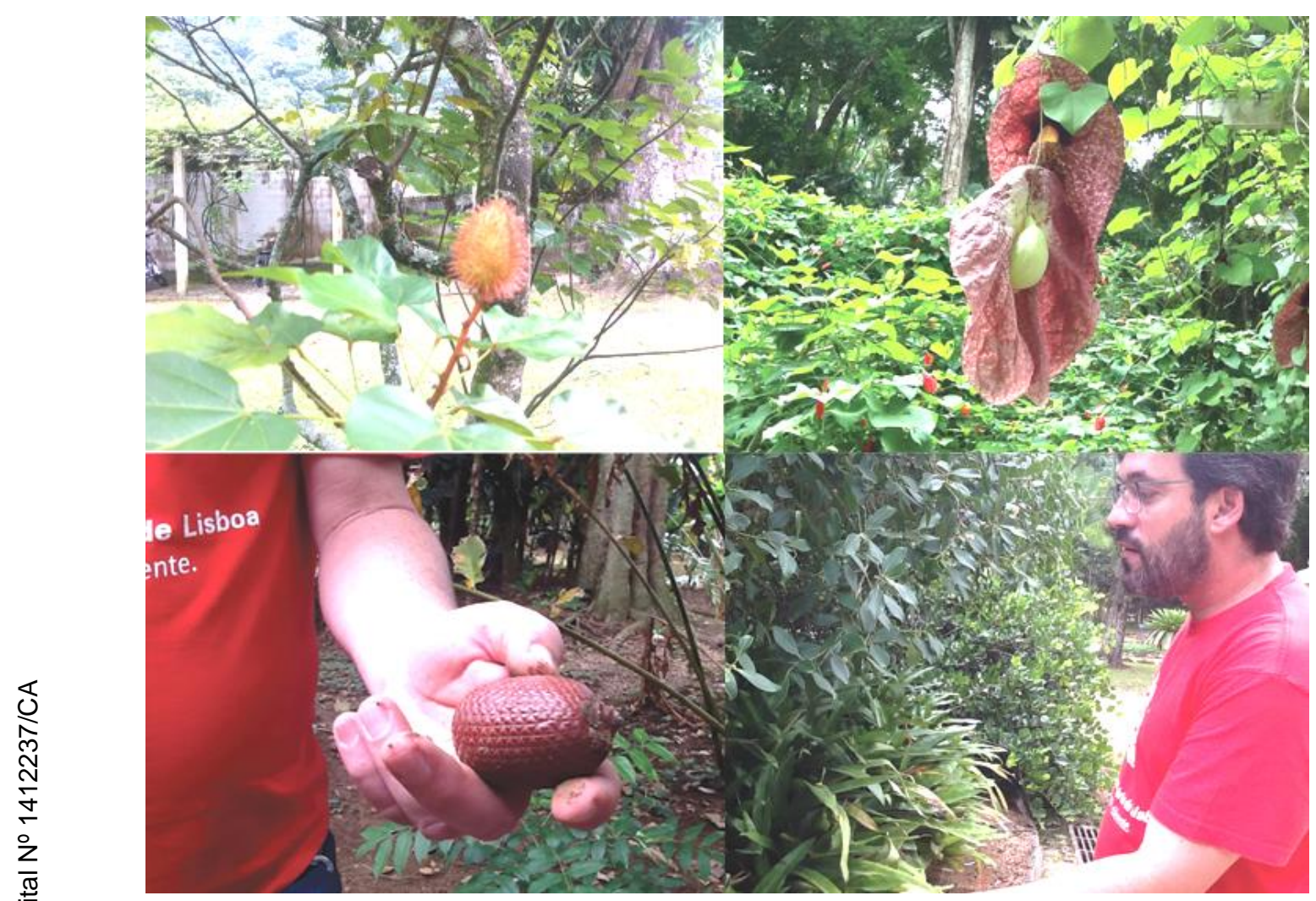

Figura 30 - Visita guiada, em agosto de 2015, ao arboreto do JBRJ, com o biólogo Claudio Nicoletti (fotos da autora).

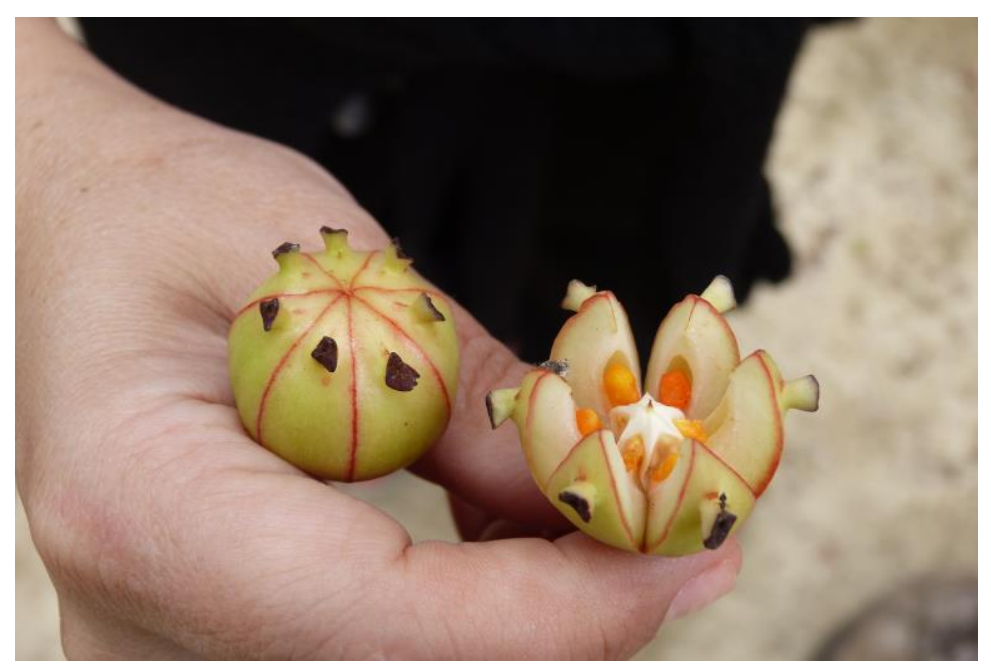

Figura 31 - Amostras de Clusia Lanceolata coletadas em visita ao arboreto do JBRJ (fotos da autora). 


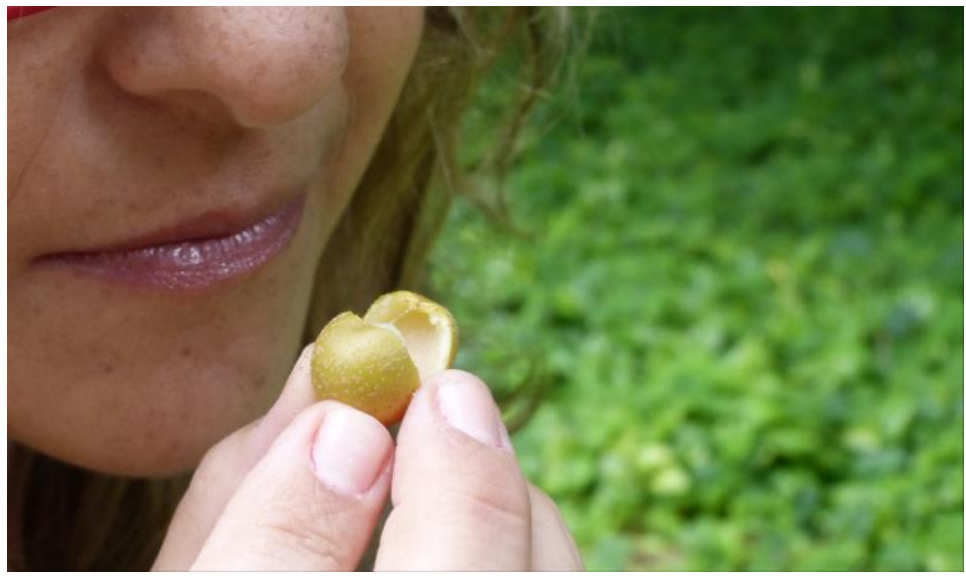

Figura 32 - Análise em campo do material coletado (foto da autora).

A coleta de materiais biológicos (A1.5) foi complementada com visitas em locais de comercialização de produtos naturais, tais como, feiras livres, lojas de especiarias, etc...

Abaixo apresentamos algumas fotos dos organismos coletados e manuseados

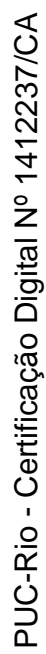
pela autora: ovos, amendoins, nozes, milho, pimentões e flores.

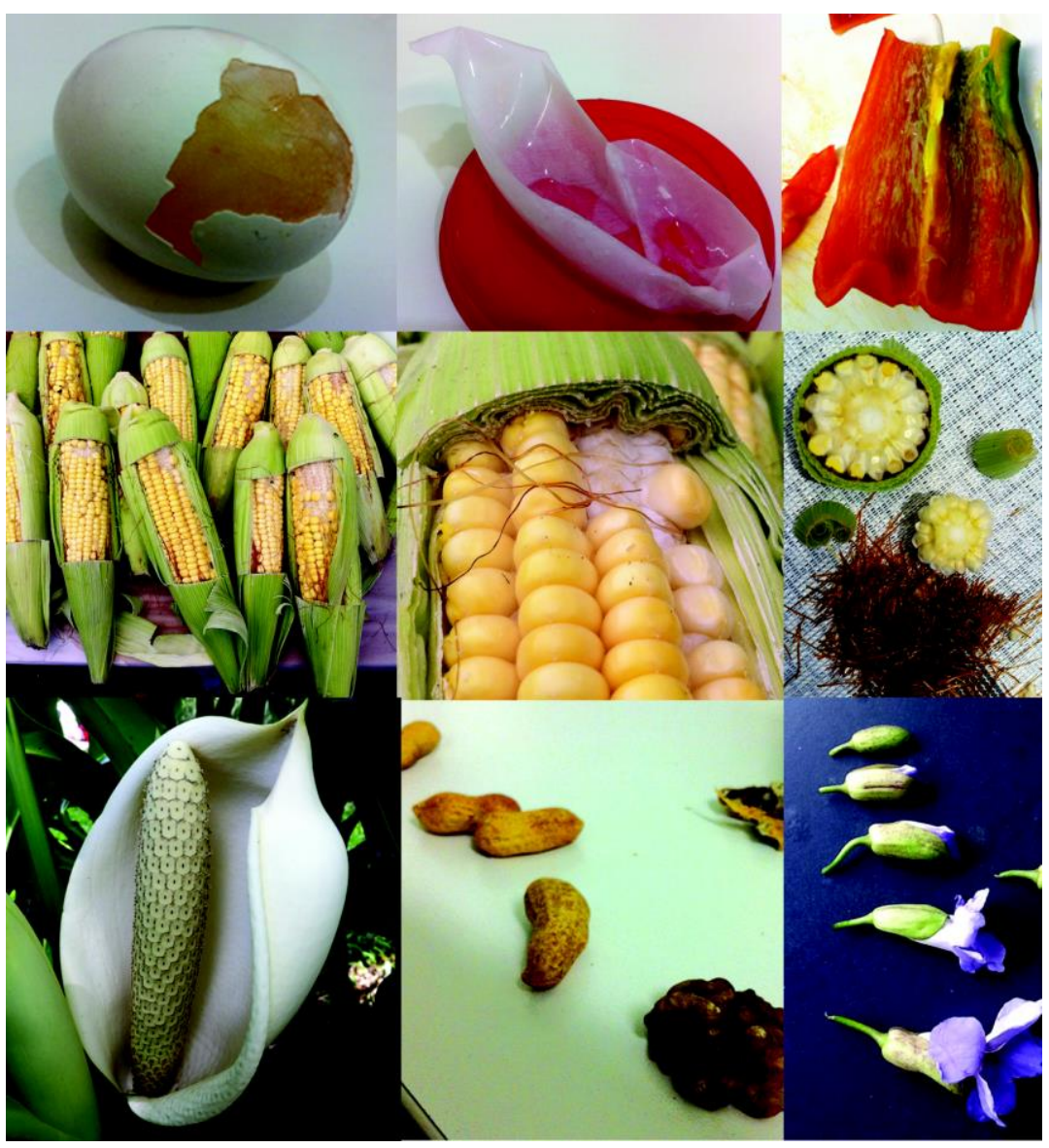

Figura 33 - Materiais biológicos coletado pela autora (fotos da autora). 
Após a observação e coleta dos organismos biológicos em seu habitat e em locais de venda de produtos naturais, encaminhamos os mesmos ao Laboratório NEXT com o propósito de analisá-los, primeiramente sem instrumentos, de forma tátil, olfativa e visual (A1.6), como pode-se constatar nas fotos abaixo.

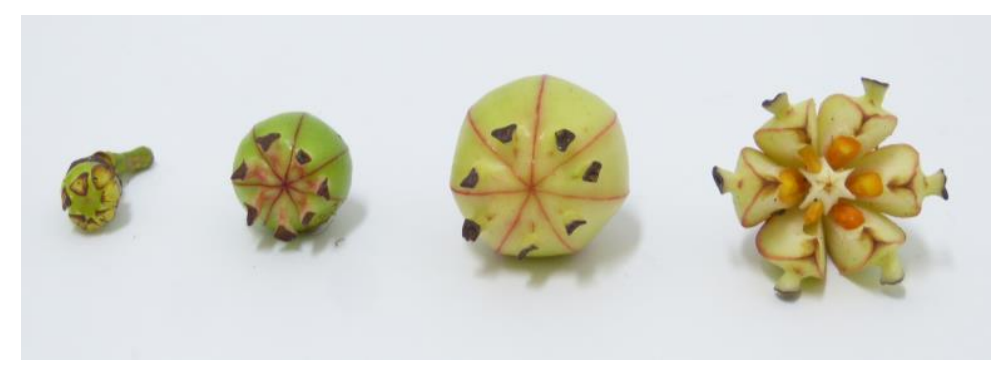

Figura 34 - Amostras de Clusia Lanceolata (coletadas em visita ao arboreto do JBRJ) e analisadas no NEXT (fotos da autora).

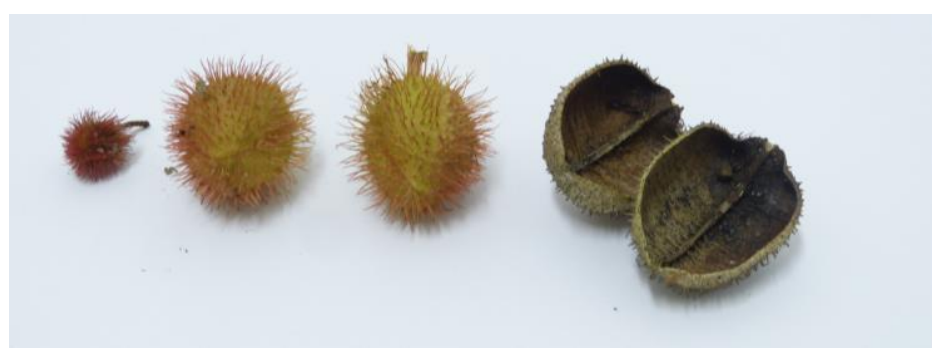

Figura 35 - Amostras de Urucum coletadas em visita ao arboreto do JBRJ e analisadas no NEXT (fotos da autora).

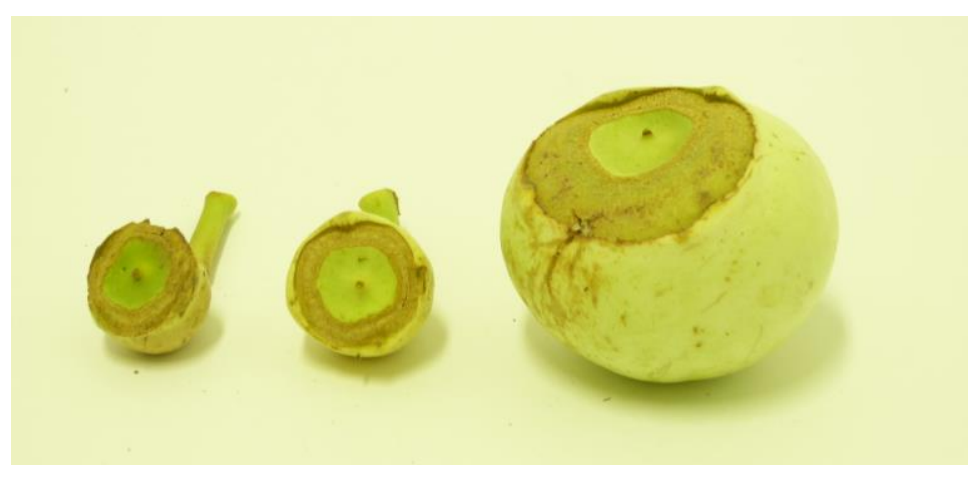

Figura 36 - Amostras de Gustavia Augusta coletadas em visita ao arboreto do JBRJ e analisadas no NEXT (fotos da autora).

Bases de dados virtuais tais como os sites: biomimicry.net, asknature.org, eol.org e designbynature.com.br, foram sistematicamente consultadas na busca de modelos naturais, que pudessem servir de inspiração para nosso experimento, e seus estudos de casos (A1.7). 
Após essa etapa de descoberta de modelos naturais inspiradores, onde optou-se pelo estudo da Botânica, iniciou-se a Etapa A2 onde selecionou-se um organismo inspirador para seguir o experimento.

\subsection{2}

\section{Etapa A2: Selecionar o organismo inspirador}

Depois de estudar as angiospermas e seu sistema flor, fruto e semente, e coletar e manusear diversos frutos, na etapa anterior dessa Experimentação A, escolheu-se como inspiração o fruto do amendoim, pertencente à família das Angiospermas Fabaceae também conhecida como Leguminosae. Uma característica típica das Leguminosaes é a ocorrência do fruto seco, do tipo legume, também conhecido como vagem. Em termos botânicos, legume ou vagem, é um fruto derivado de um único carpelo (ovário), deiscente (quando se abre espontâneamente), e que abre-se por duas fendas longitudinais, como se pode observar na ilustração abaixo. (OLIVEIRA, 2008, pg. 219).

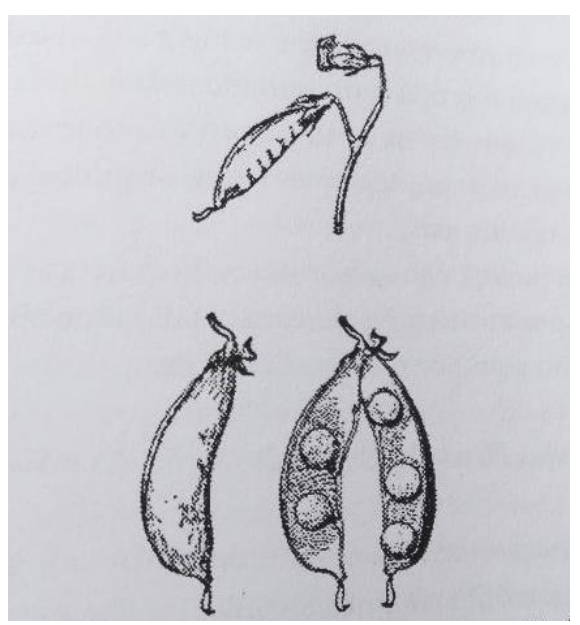

Figura 37 - Ilustração de fruto do tipo vagem, de uma leguminosa (ervilha), com sementes. (Textbook of General Botany, New York, Macmillan, 1953).

Escolheu-se o amendoim (Arachis Hypogea L) por tratar-se de um fruto leguminoso com peculiaridades em relação a acomodação, proteção e conservação de suas sementes, entre elas: leveza, resistência, impermeabilidade, abertura facilitada e adaptabilidade a diferentes quantidades de sementes. Analisou-se que essas peculiaridades inspirariam analogias para o design de embalagem. 
Arachis, o nome do gênero (nome comum a todas as espécies que pertencem a este mesmo gênero) significa "noz" e hypogaea significa "debaixo de terra". A letra "L." é a abreviatura de Lineu, o primeiro a descrever e classificar a planta do amendoim, em 1753. A serra do Amambaí, no limite do Mato Grosso do Sul e Paraguai, é considerada o local de origem do gênero Arachis, por ali viver a guaranitica, possivelmente a espécie mais antiga do gênero. Existem aproximadamente 80 espécies neste gênero, 64 destas ocorrem no Brasil, sendo 48 restritas ao território brasileiro. Quinze estão distribuídas na Bolívia, 14 no Paraguai, 06 na Argentina e 02 no Uruguai (VALLS; SIMPSON, 1994).

A ilustração abaixo, retirada do site Plant Illustration, mostra o sistema flor, fruto e semente do amendoim (Arachis Hypogea L).

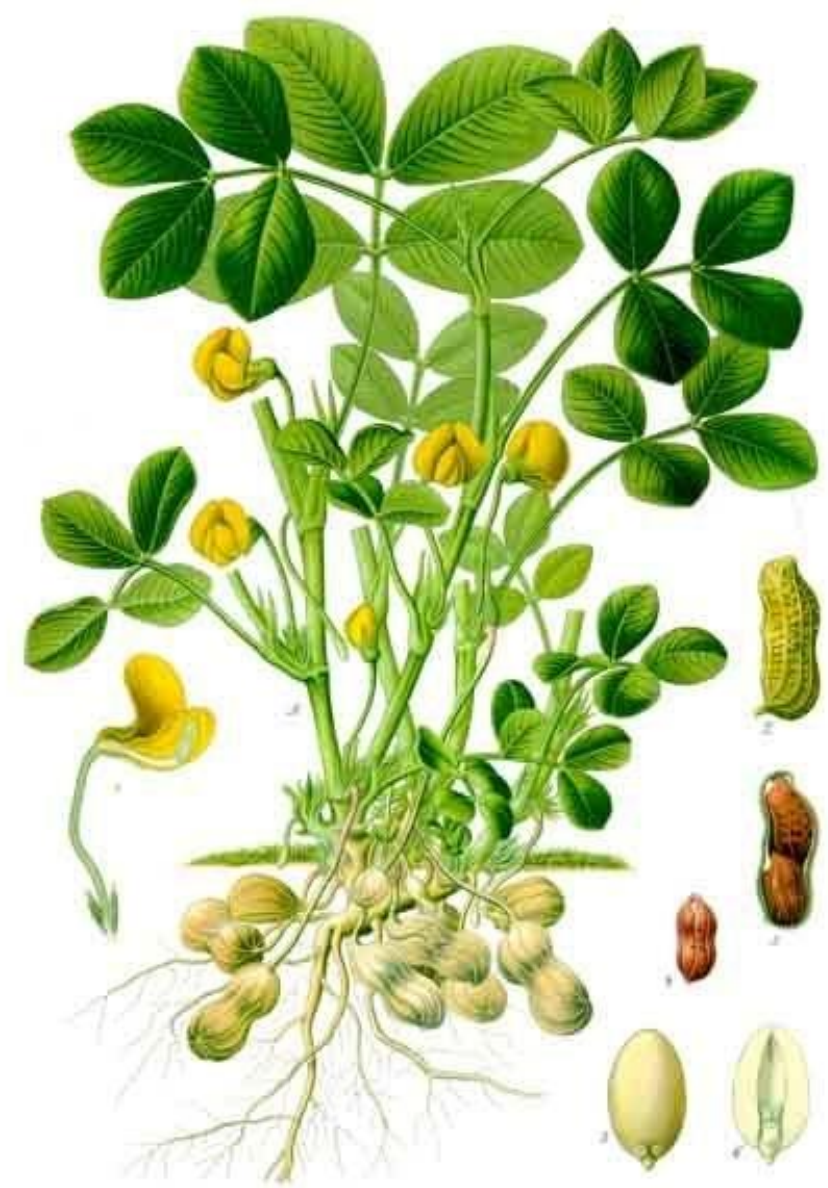

Figura 38 - Ilustração de Arachis Hipogea L. Disponível em www.plantillustration.org. Acessado em 7 dez 2015. 


\subsection{3.}

\section{Etapa A3: Abstrair estratégias biológicas}

Procurou-se, com o apoio de um biólogo, entender as peculiaridades do amendoim a fim de abstrair as estratégias biológicas usadas por esse organismo para evoluir e sobreviver.

Para entender essas peculiaridades procurou-se inicialmente fazer perguntas sobre: como o fruto funciona? O que o faz único? Poderá essa casca ser impermeável? Em que direção ela quebra mais fácil? Como ela se forma e cresce? Quem se alimenta desse fruto?

Essas perguntas, juntamente com uma análise morfológica do amendoim, nos ajudaram a descobrir estratégias interessantes desses organismos que poderiam ser transferidos para o design de embalagem de alimentos.

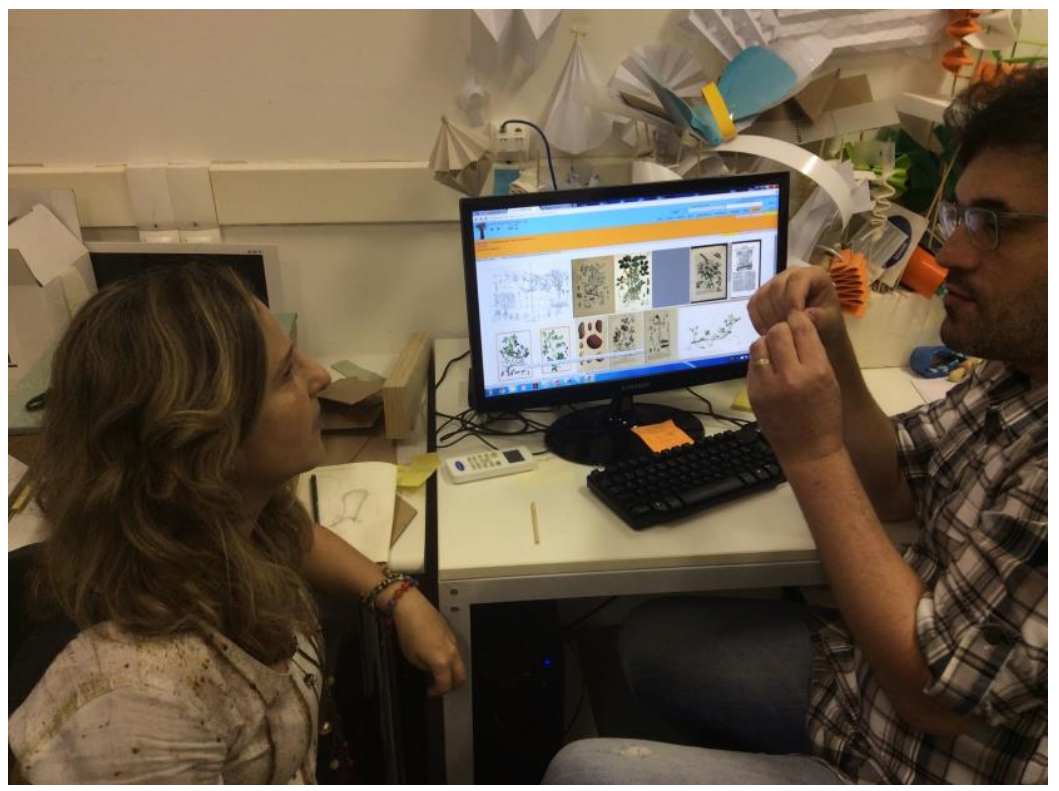

Figura 39 - Visita do biólogo Dr. Claudio Nicoletti de Fraga ao NEXT na etapa de abstração de estratégias biológicas do amendoim.

A análise morfológica é uma ferramenta projetual usada por designers no desenvolvimento de novos produtos. Ao trabalhar com essa ferramenta deve-se identificar os diversos elementos que compõem um sistema ou conjunto (conjuntos, subconjuntos, componentes, partes, etc,..) e estabelecer uma estrutura hierárquica e relacional entre eles. Além disso, analisa-se o conjunto quanto à sua estrutura, forma, configuração, construção, materiais e processos. Foi desenvolvida por um engenheiro, Fritz Zwickey, em 1948, quando o mesmo trabalhava no desenvolvimento de motores a jato (Baxter, 1998). 
A vagem do amendoim, composta pela casca e pelas bagas (conjunto do fruto do amendoim propriamente dito), foi analisada morfologicamente segundo os seguintes pontos: análise da configuração construtiva (a), formal (b), estrutural (c), de processos (d), de materiais (e). Ao final de cada análise, descreveu-se o que conseguiu-se abstrair das estratégias adotadas pelo organismo.

\section{a. Análise da Configuração construtiva:}

Conjunto casca (vagem) que envolve o subconjunto bagas (sementes). Desenvolvem-se simultaneamente antes de enterrarem-se no solo, uma vez maduros. A casca do fruto acomoda e protege as sementes, tanto ao ar livre quanto embaixo da terra. Diferentes amendoins foram analisados, como apresentado abaixo.

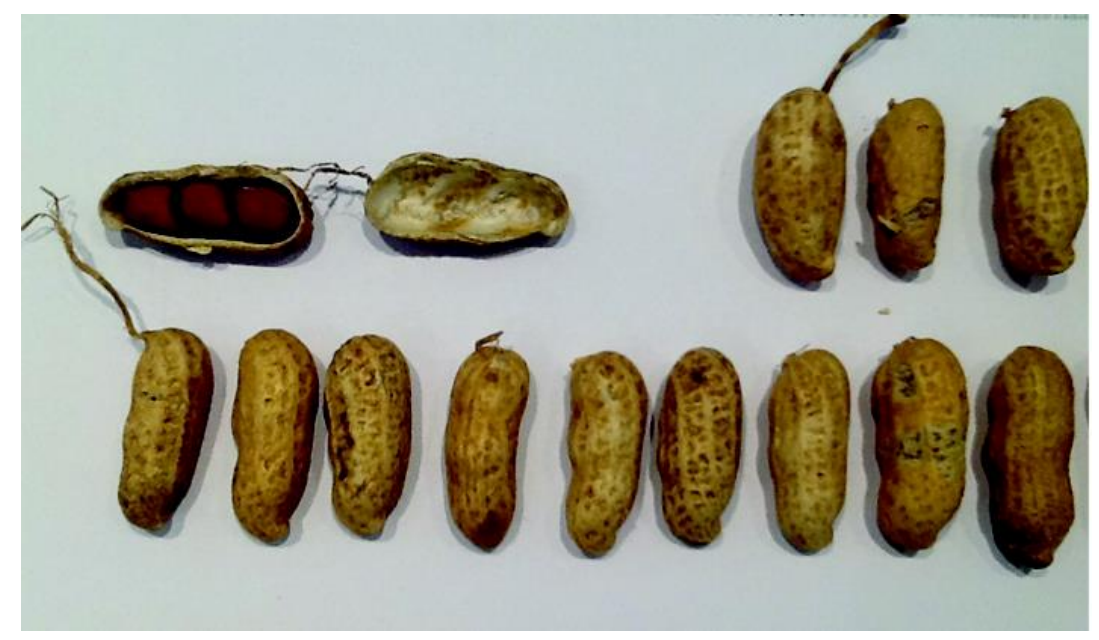

Figura 40 - Vagens do amendoim com o conjunto de casca e bagas (foto da autora).

b. Análise da configuração formal:

Conjunto com forma natural, espontânea, irregular, variável, assimétrica e contínua, que reúne em seu interior quantidades varáveis de elementos do subconjunto (bagas ou sementes).

Estratégia abstraída: Forma integral, adaptável a diferentes quantidades de sementes.

\section{c. Análise da configuração estrutural:}

A casca quebra em duas partes ao aplicar-se pressão com os dedos no sentido longitudinal (sentido do comprimento) da vagem. Pode-se verificar, nas fotos abaixo, o resultado da quebra intencional da casca de alguns amendoins. 


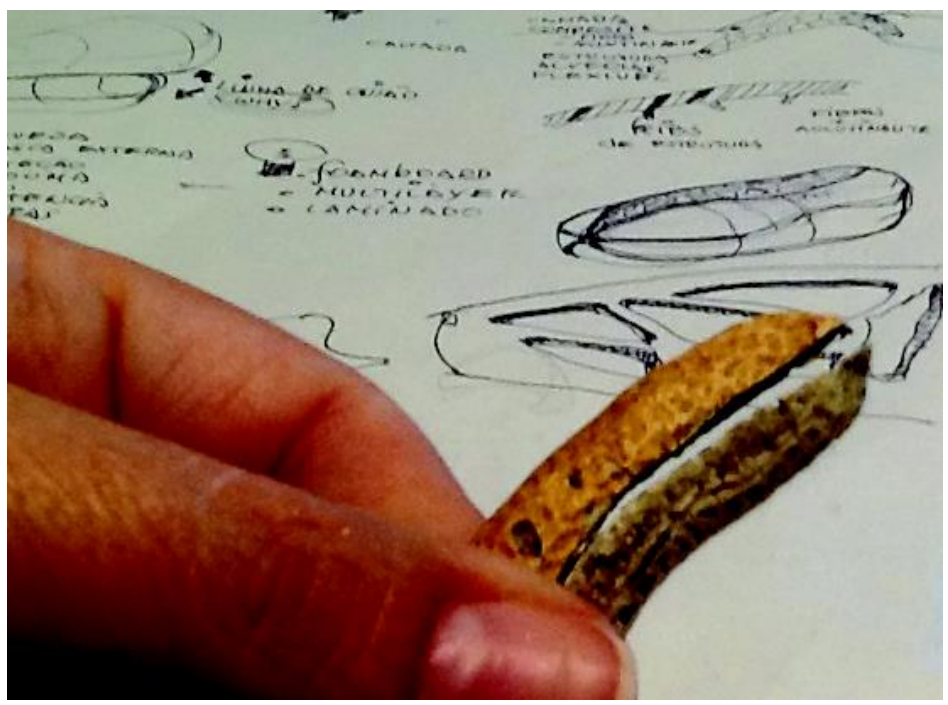

Figura 41 - Casca da vagem do amendoim e sua linha de quebra após aplicação de pressão na região longitudinal (fotos da autora).

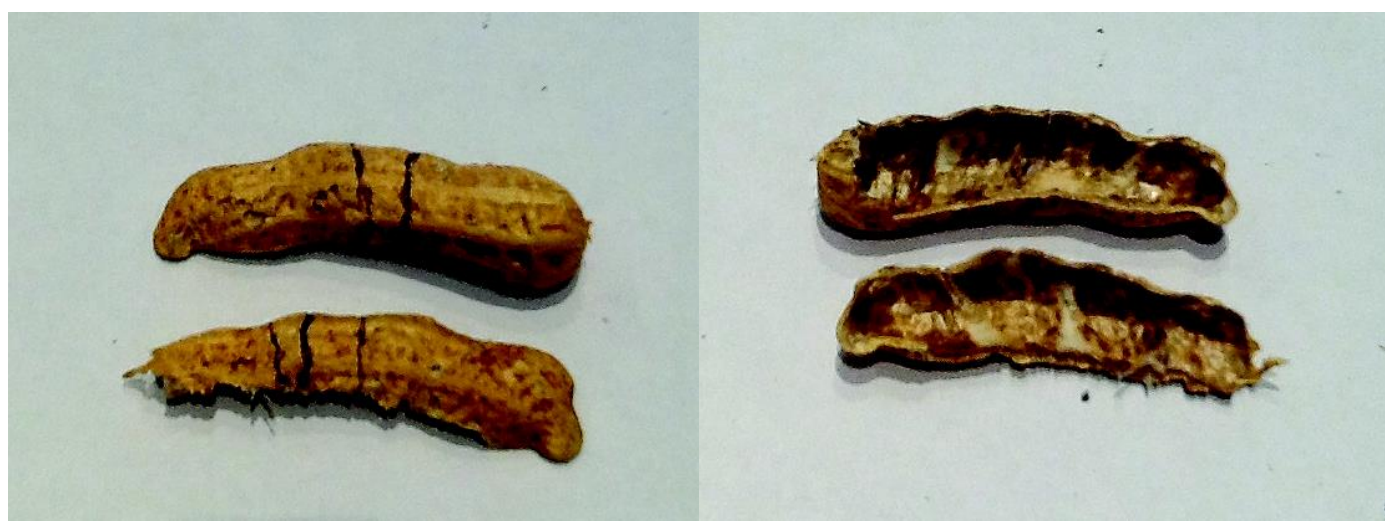

Figura 42 - Casca de vagens do amendoim aberta longitudinalmente em duas partes (foto da autora).

Estratégia abstraída: Fragilidade na região longitudinal da casca da vagem que "quebra" por meio de pressão intencional localizada, disponibilizando as sementes sem danificá-las.

A casca da vagem do amendoim apresenta várias camadas de materiais com aparência externa diferente da interna, como pode-se constatar nas fotos abaixo.
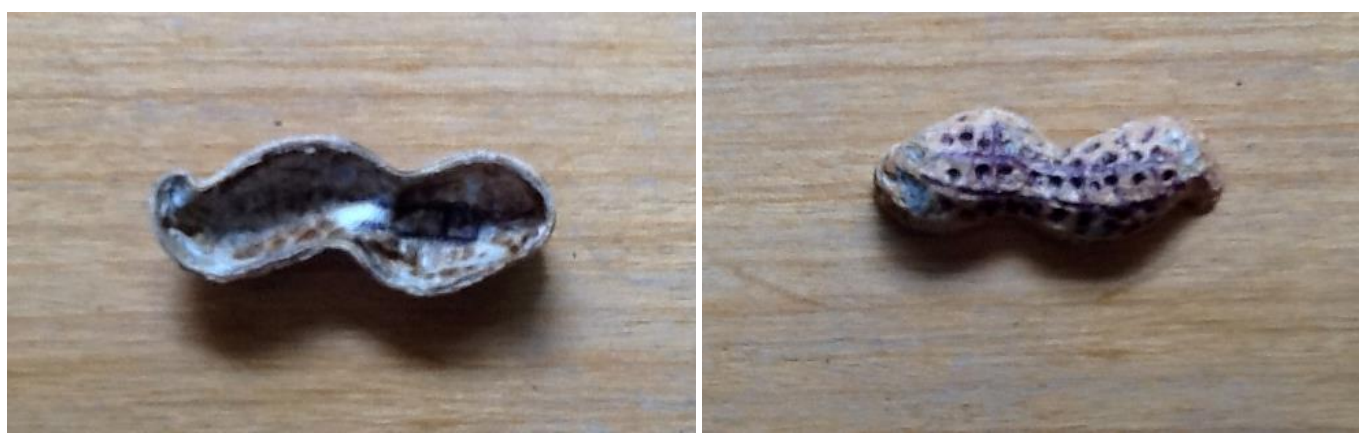

Figura 43 - Fruto do amendoim aberto e sua aparência interna e externa (foto da autora). 
Observa-se, a "olho nu", na casca das amostras examinadas, uma série de fibras estruturais longitudinais que dão estrutura e resistência, formando um conjunto rígido: fibras intercaladas com camadas de materiais. Reproduzimos, por meio dos desenhos abaixo, o que observamos dessa configuração estrutural.

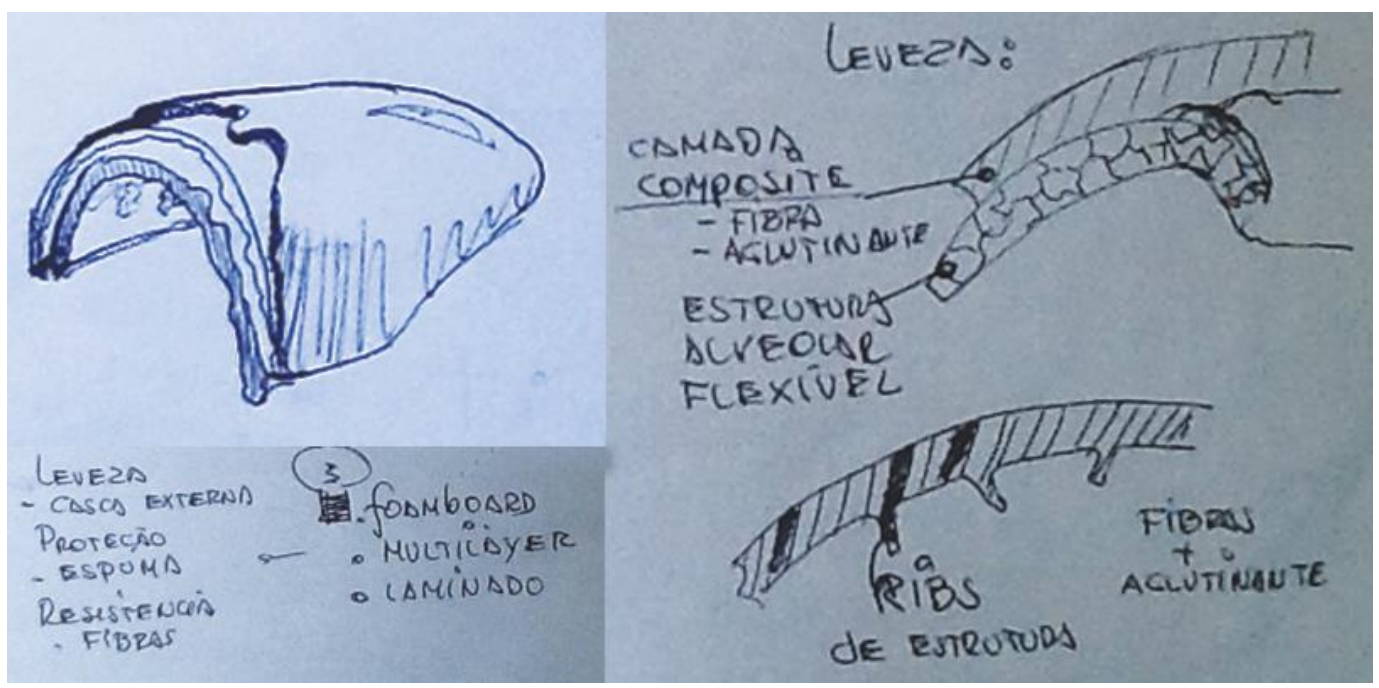

Figura 44 - Desenhos feitos a partir de observação a "olho nu" da casca do amendoim, representando a configuração estrutural da mesma (desenhos da autora).

Para uma análise mais aprofundada da casca da vagem do amendoim iniciou-se um processo invasivo de retirada, por meio de atrito e fricção, da camada mais superficial da casca. Na foto abaixo, vê-se claramente um lado da casca sem a camada externa de recobrimento. Também foi possível analisar a espessura das fibras longitudinais e suas ramificações. 


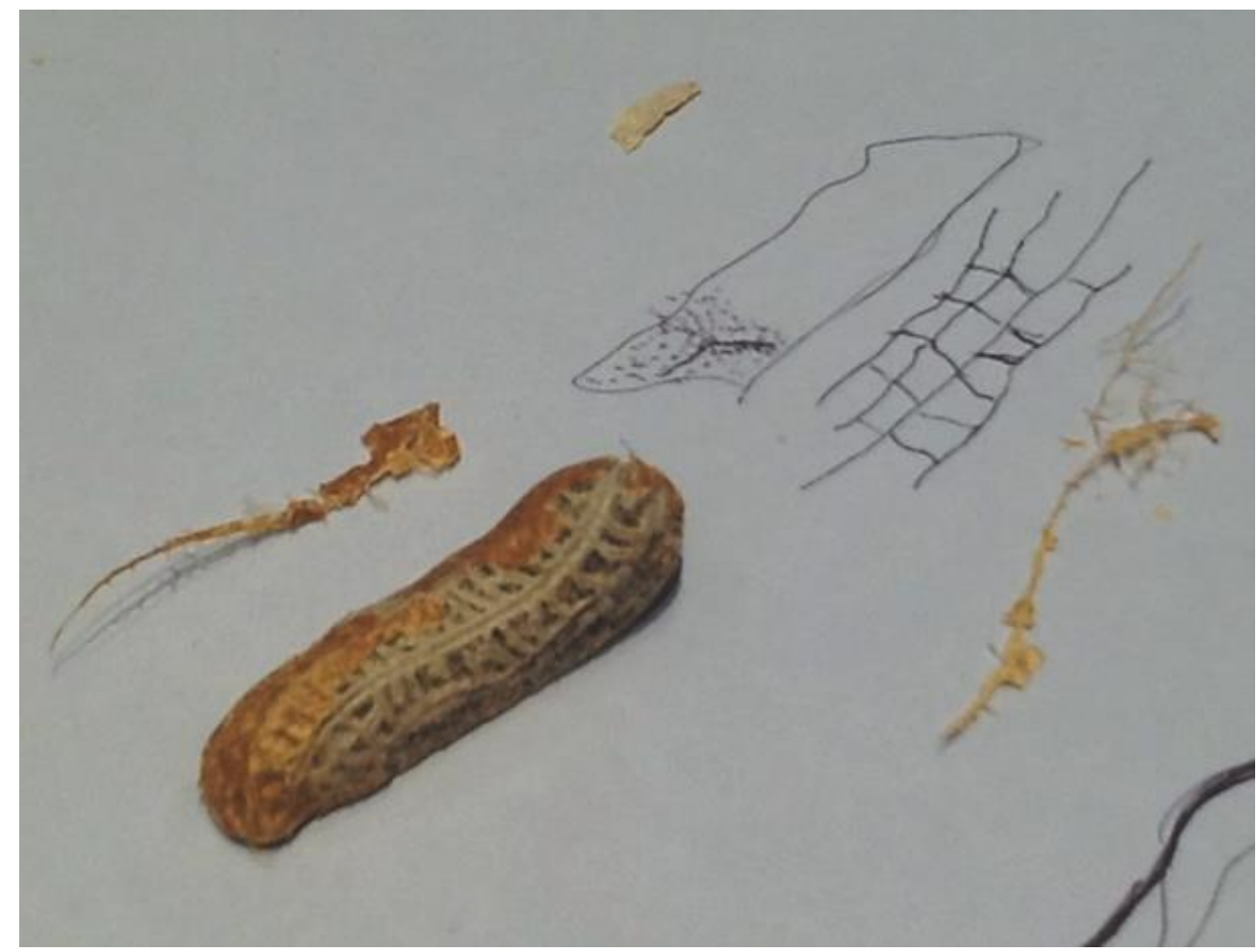

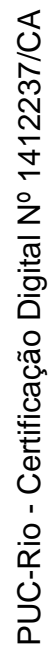

Figura 45 - Análise invasiva, por meio de fricção, da casca da vagem do amendoim com suas fibras e multicamadas (fotos da autora).

Os desenhos abaixo (em vistas superior, inferior, frontal e lateral) foram realizados a partir da observação de amostras da casca da vagem do amendoim e mostram a direção das fibras estruturais, configurando as "linhas de força estruturais" da vagem.

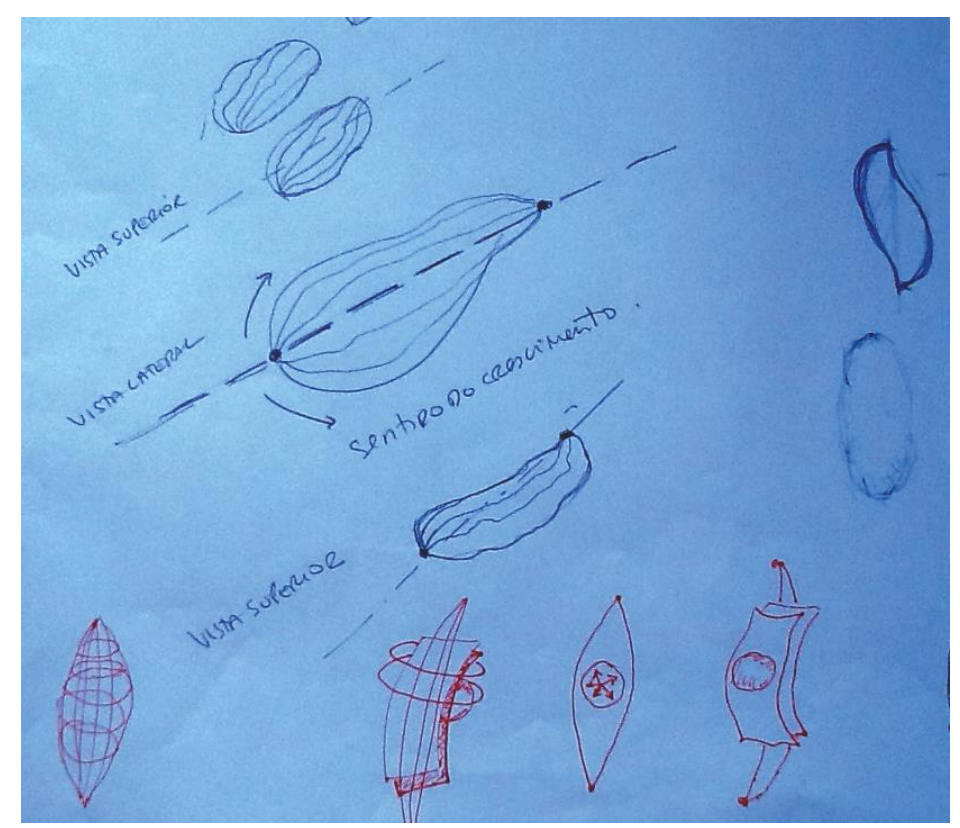

Figura 46 - Análise do sentido do crescimento das fibras da vagem do amendoim (desenhos da autora). 


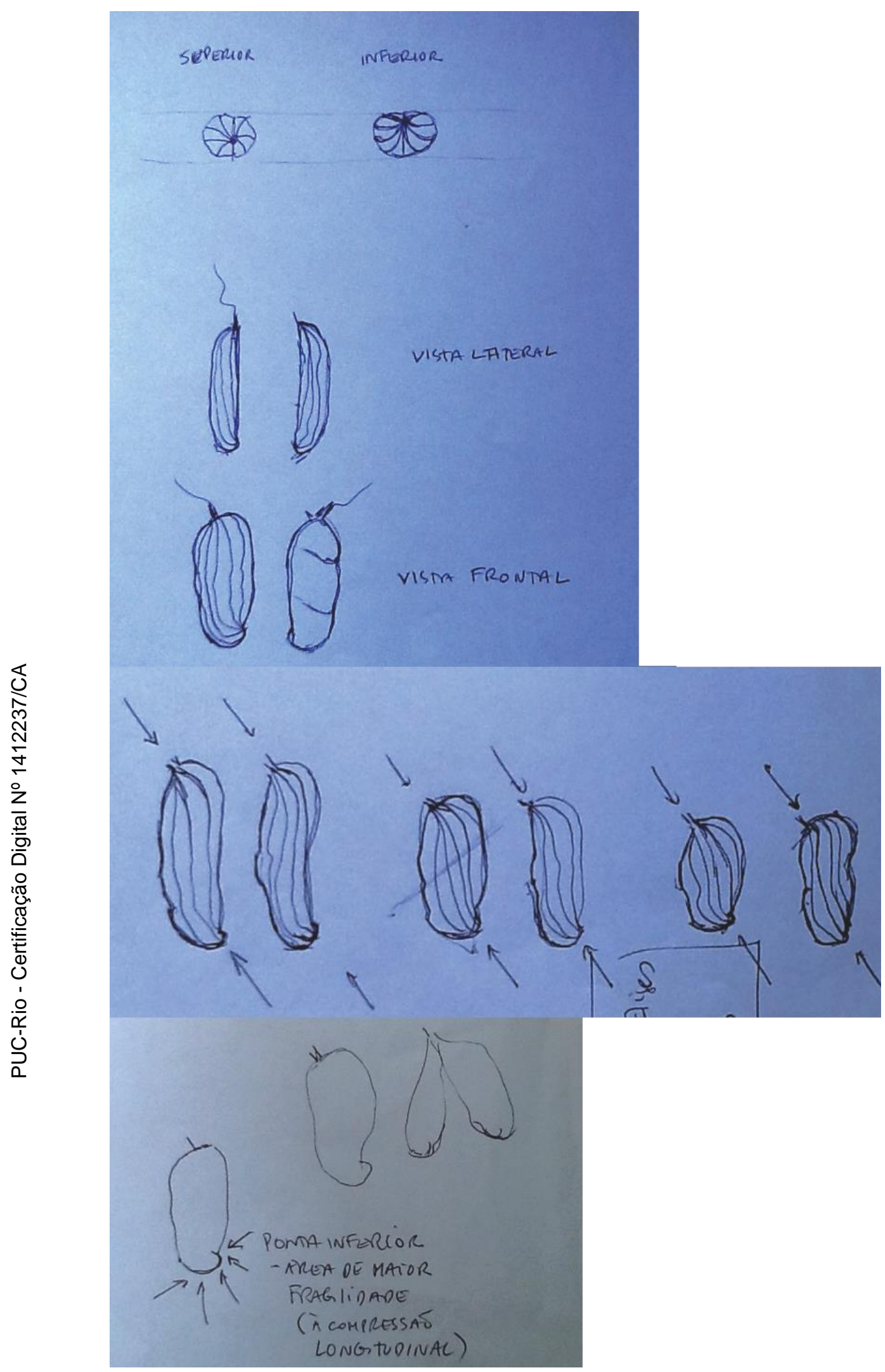

Figura 47 - Desenhos, em vistas, das linhas de força estruturais da vagem do amendoim (fotos da autora). 
Estratégia abstraída: Casca rígida, composta por conjunto de fibras longitudinais e multicamadas de materiais.

Observa-se na superfície externa da casca (foto abaixo - a "olho nu"), uma série de pequenas depressões ao longo da superfície, com o aspecto de trapézios.

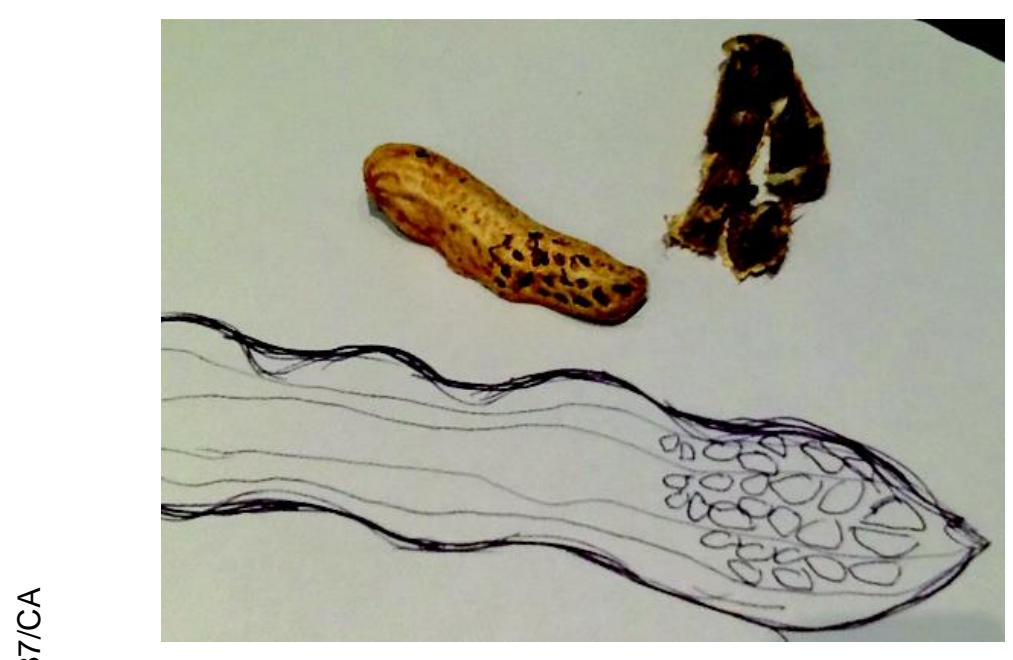

Figura 48 - Análise de "depressões" na superfície externa da casca da vagem do amendoim (desenhos da autora).

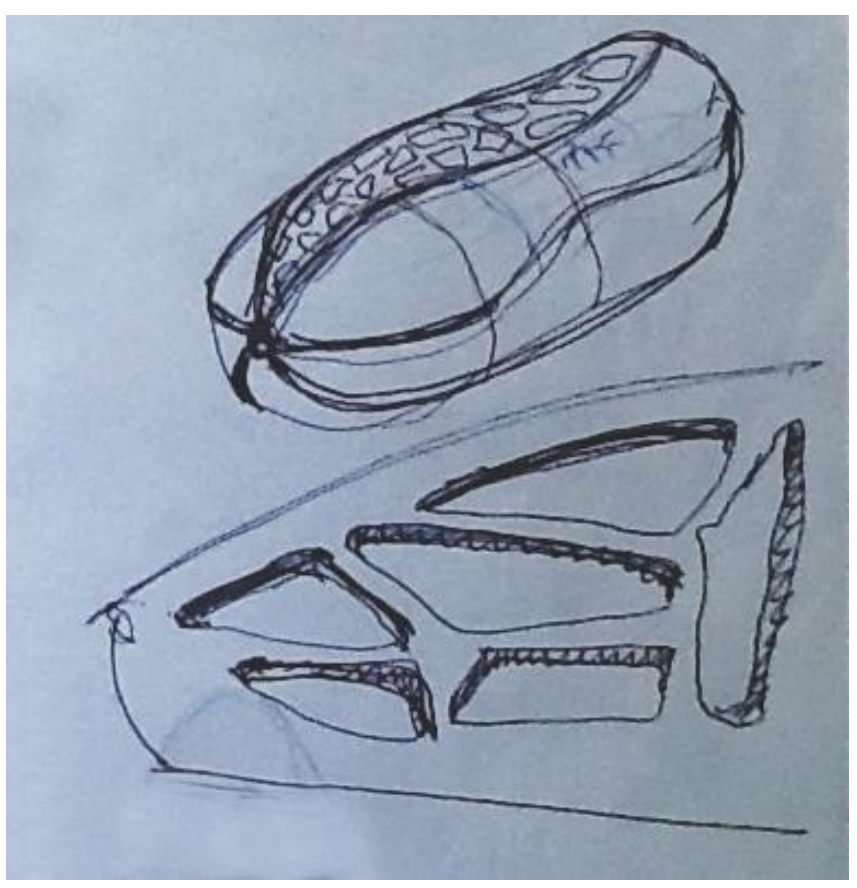

Figura 49 - Desenho, a partir da observação a "olho nu" de detalhe de "depressões" na superfície externa da casca do amendoim (desenhos da autora).

Estratégia abstraída: casca leve, devido à diminuição da espessura nas depressões. 


\section{d. Análise de processos:}

As flores do amendoim, depois de fecundadas, penetram no solo, com a ajuda de uma estrutura denominada ginóforo e de um fenômeno conhecido como geocarpia, onde os legumes desenvolvem-se subterraneamente como apresentado na ilustração abaixo (VALLS; SIMPSON, 1994).

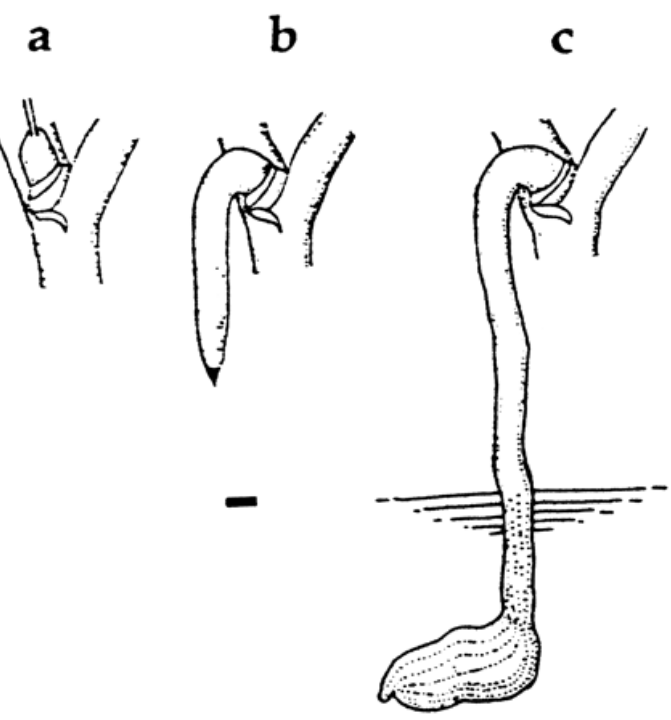

Figura 50 - Ilustração do fenômeno de geocarpia, onde o amendoim desenvolve-se subterraneamente (VALLS; SIMPSON, 1994).

Estratégia abstraída: Amadurecimento do fruto embaixo da terra, permitindo proteção contra predadores.

e. Análise de materiais:

Os materiais da casca são compostos de por hidratos de carbono, celulose e proteínas e constitui 4-5\% do peso do produto. Desempenham a função de barreira contra agentes externos (água, ar, terra, vento, etc...). Os bagos são ricos em proteínas (cerca de 25\%) e sobretudo em lípidos (quase 50\%) (VALLS; SIMPSON, 1994).

Estratégia abstraída: Impermeabilidade.

Finaliza-se esse capítulo com uma síntese das estratégias biológicas abstraídas da vagem do amendoim (fruto), representada no quadro abaixo. 


\begin{tabular}{|l|l|}
\hline VAGEM DO AMENDOIM & Estratégias biológicas abstraídas \\
\hline & Forma integral, adaptável a diferentes quantidades de sementes. \\
\hline & $\begin{array}{l}\text { Fragilidade na região longitudinal da vagem, } \\
\text { que "quebra" por meio de pressáo intencional localizada, } \\
\text { disponibilizando as sementes sem danificá-las. }\end{array}$ \\
\hline & $\begin{array}{l}\text { Amadurecimento do fruto embaixo da terra, } \\
\text { permitindo proteção contra predadores. }\end{array}$ \\
\hline
\end{tabular}

Quadro 3 - Síntese das estratégias biológicas abstraídas da vagem do amendoim (quadro da autora)

Na próxima etapa, essas estratégias servirão de base para entendermos as funções desse organismo.

\subsection{4.}

\section{Etapa A4: Identificar a função e definir contexto}

Essa etapa visa entender as funções de um determinado organismo, no nosso caso o fruto do amendoim. Trata-se de identificar uma característica, mecanismo, processo, que faz alguma coisa (uma função) para esse organismo. São as "coisas" que a estratégia faz para o organismo, e definir o contexto onde essa função é desejada.

O quadro 4, abaixo, lista as estratégias abstraídas na Etapa 3A, e atribui funções para cada uma delas, segundo um contexto relacionado ao design de embalagem. 


\section{VAGEM DO AMENDOIM}

\begin{tabular}{|l|l|}
\hline Estratégias biológicas abstraídas & Funções \\
\hline Forma integral, adaptável a diferentes quantidades de sementes. & Permitir adaptações dimensionais \\
\hline $\begin{array}{l}\text { Fragilidade na região longitudinal da vagem, } \\
\text { que "quebra" por meio de pressão, } \\
\text { disponibilizando as sementes sem danificá-las. }\end{array}$ & $\begin{array}{l}\text { Abrir, permitindo acesso ao conteúdo quando } \\
\text { desejado e sem danificá-lo. }\end{array}$ \\
\hline $\begin{array}{l}\text { Amadurecimento do fruto embaixo da terra, } \\
\text { permitindo proteção contra predadores. }\end{array}$ & $\begin{array}{l}\text { Promover segurança ao conteúdo contra } \\
\text { agentes externos. }\end{array}$ \\
\hline $\begin{array}{l}\text { Impermeabilidade } \\
\text { Casca rígida, composta por conjunto de fibras longitudinais e } \\
\text { multicamadas de materiais. }\end{array}$ & Proteger contra umidade. \\
\hline \begin{tabular}{l} 
Casca leve, devido à diminuição da espessura nas depressões. \\
\hline
\end{tabular} & $\begin{array}{l}\text { Resistir a quedas, amassamentos, torção, } \\
\text { punção e impacto. }\end{array}$ \\
\hline
\end{tabular}

Quadro 4 - Estratégias biológicas da vagem do amendoim e funções (quadro da autora).

\subsection{5.}

\section{Etapa A5: Brainstorm: ideias bioinspiradas}

Abstraídas as estratégias, definidas as funções do fruto do amendoim e definido o contexto relacionado ao design de embalagem, nossa próxima ação (baseada na metodologia Biologia para Projetar, do Biomimicry 3.8, 2013) foi gerar ideias combinando esses elementos para resolver problemas.

Para tanto, deve-se perguntar: que tipo de problemas relacionados ao design de embalagem pode-se resolver por analogias, ou seja, transferindo estratégias e funções do amendoim? O que você precisa que a solução de design de embalagem faça?

Para auxiliar nessa transferência, usou-se materiais e habilidades de desenho e sketches. As sequências de desenhos abaixo foram realizadas em diversas sessões criativas para geração de conceitos de embalagem. 


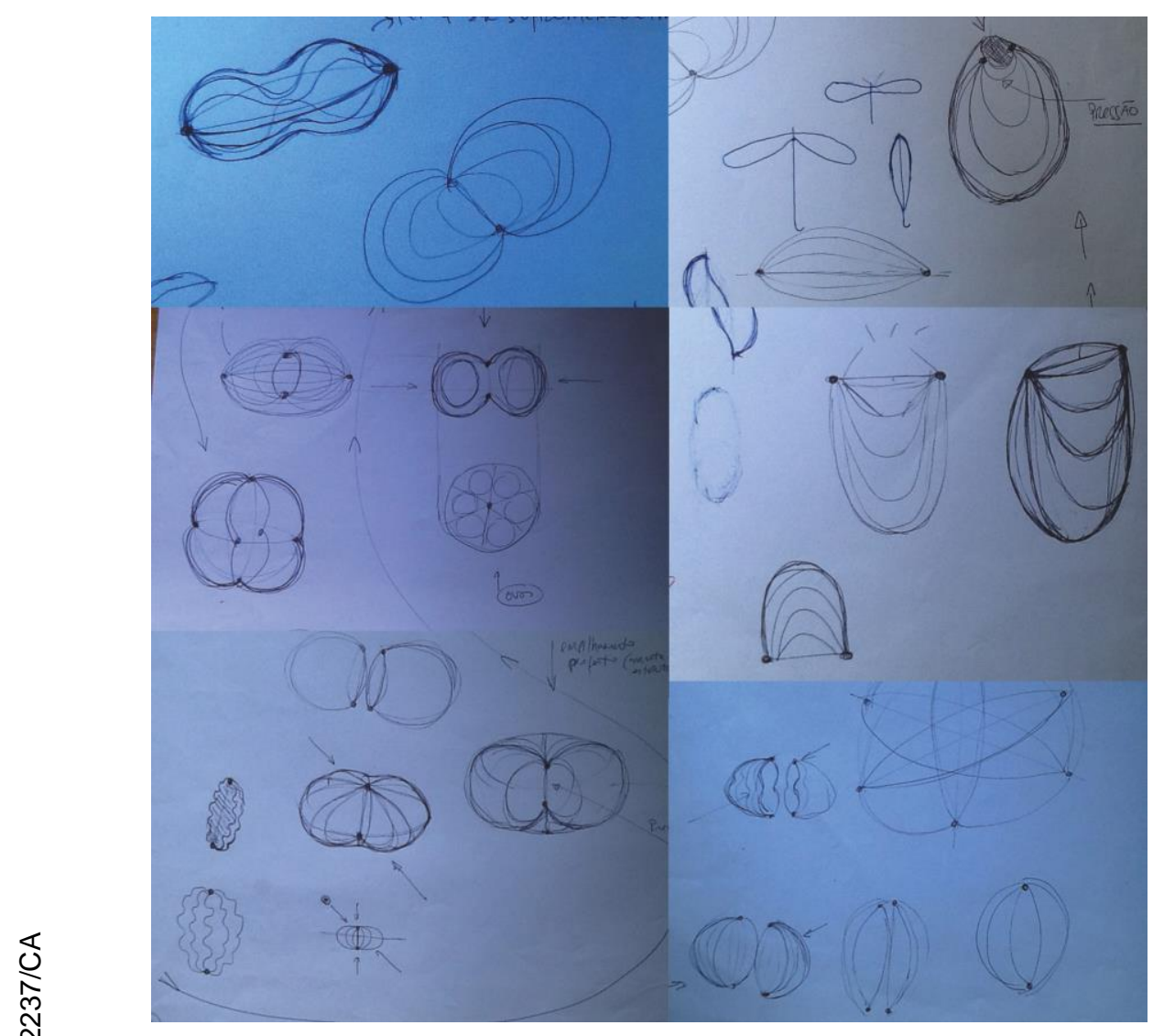

Figura 51 - Sketches com geração de ideias a partir da transferência de estratégias de linhas de força (desenhos da autora).

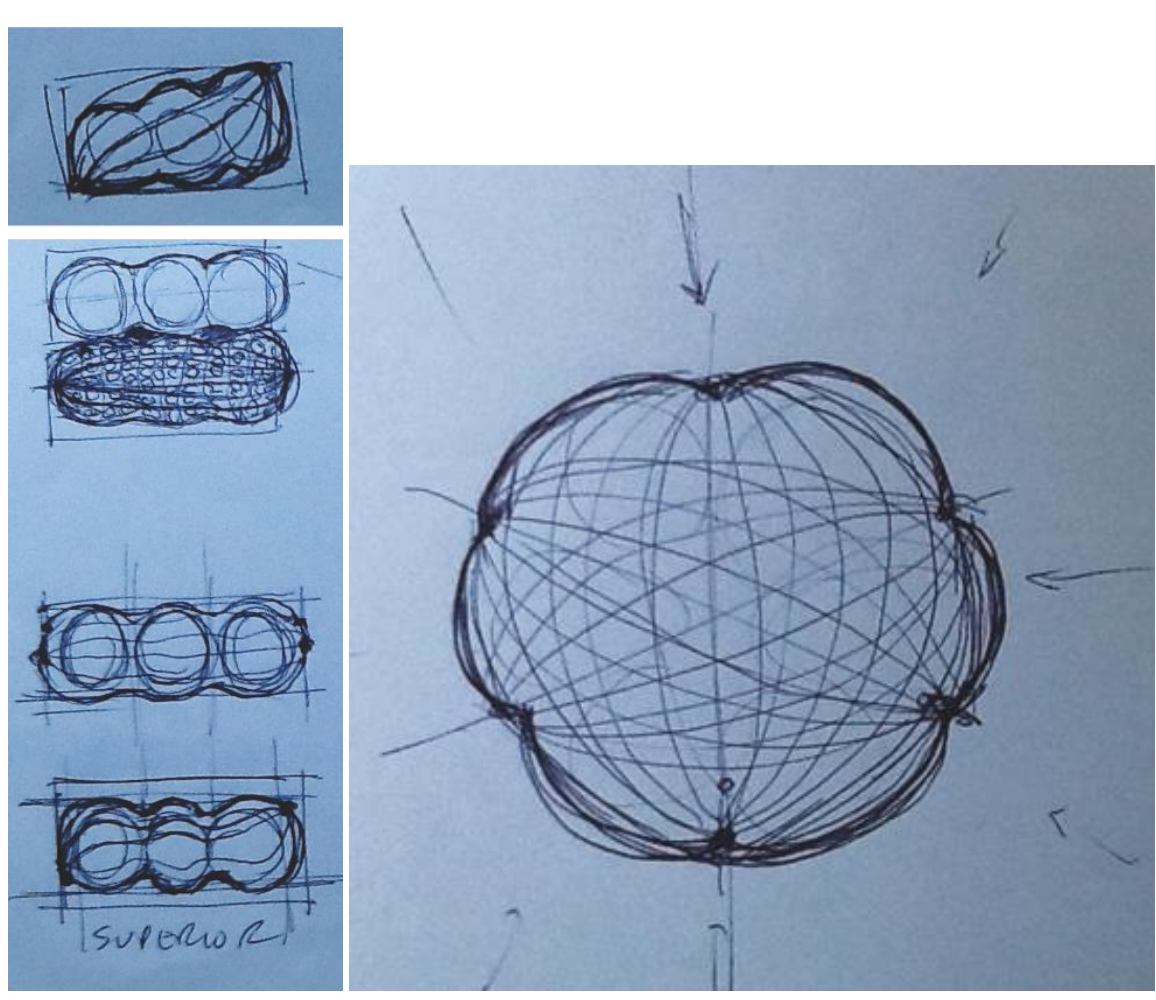

Figura 52 - Sketches com geração de ideias a partir da transferência de estratégias de linhas de força (desenhos da autora). 


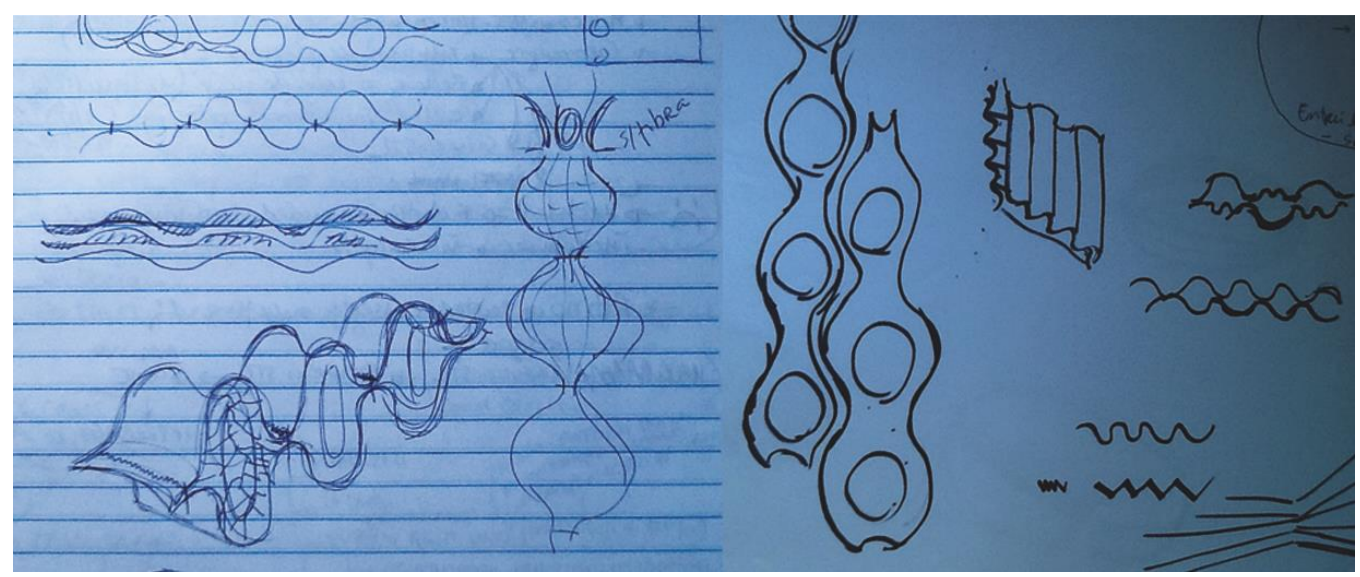

Figura 53 - Sketches com geração de ideias a partir da transferência de estratégias formais (desenhos da autora).

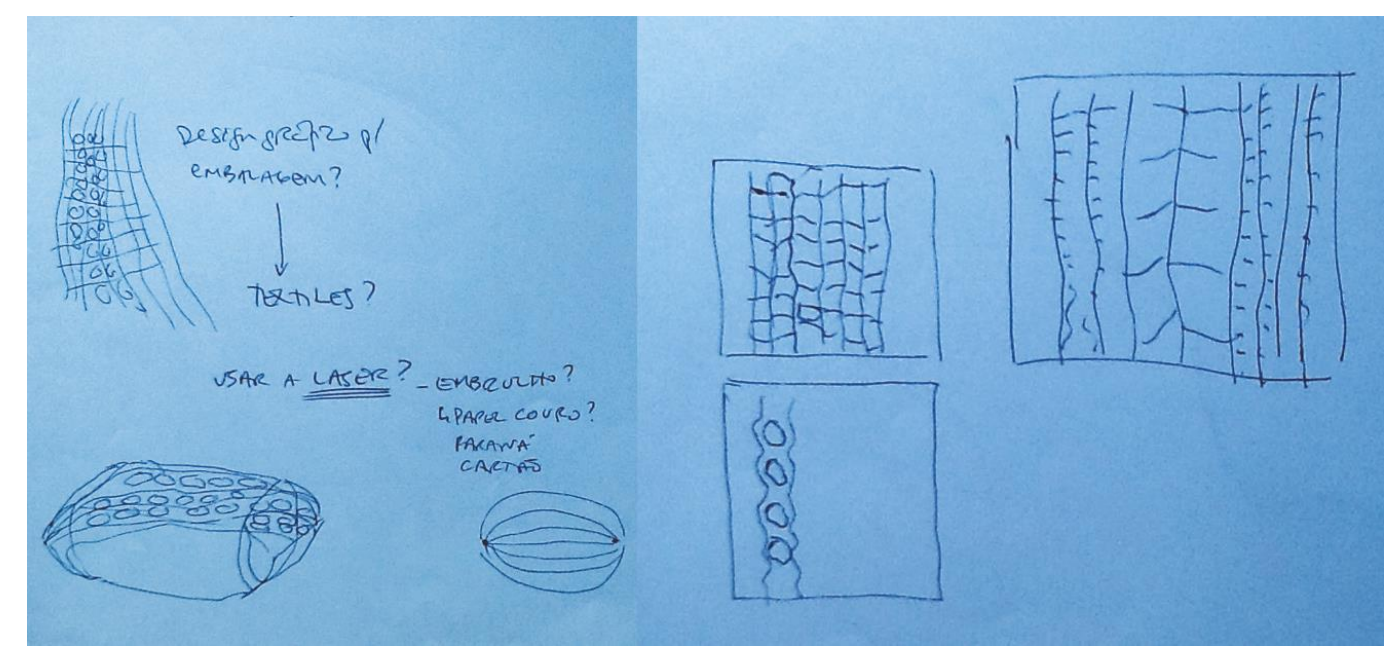

Figura 54- Sketches com geração de ideias a partir da transferência de estratégias de padrões geométricos (desenhos da autora).

\subsection{6.}

\section{Conclusão do Experimento A}

A Experimentação A abrangeu as seguintes Etapas: Descobrir modelos naturais (A1); Selecionar organismo inspirador (A2); Abstrair estratégias biológicas (A3); Identificar função e definir contexto (A4); Brainstorm ideias bioinspiradas (A5). Foi realizada a partir do pensamento Biomimético, Biologia para Projetar (Biomimicry 3.8, 2007), porém, diferentemente da metodologia usada pelo Biomimicry 3.8, não integrou-se princípios da vida à solução, ou seja não fez-se a avaliação das ideias bioinspiradas usando os princípios da vida como um chekcklist, nem tampouco avançou-se nas Etapas posteriores ao Brainstorm, o que a autora avalia ser necessário futuramente para uma análise comparativa mais aprofundada sobre os resultados com uso, ou não, das novas tecnologias digitais, 
pois, no Experimento A, não foram utilizadas novas tecnologias digitais, como microtomógrafo e impressora 3D, e o Experimento B fez uso intenso dessas tecnologias.

Constatou-se que foi fundamental o apoio do biólogo em visitas ao Jardim Botânico e na orientação teórica sobre o Reino da Plantas (Angiospermas), durante a Etapa A1 (descobrir um organismo ou ecosistema inspirador, e aprender sobre suas estratégias para evoluir e sobreviver). As bases de dados virtuais abriram um amplo campo de conhecimento, porém são difícies de consultar, por esse motivo privilegiou-se o contato direto com o biólogo.

A escolha do fruto do amendoim como organismo inspirador, mostrou-se acertada, pois as abstrações de suas estratégias biológicas geraram insights sobre as funções e o contexto onde as mesmas são desejadas, no caso dessa pesquisa, o design de embalagem.

É importante ressaltar que nesse experimento não houve o apoio das novas tecnologias digitais, portanto, foi muito importante a experiência da autora como designer para, a olho "nú", realizar uma análise morfológica e abstratir as estratégias do organismo e posteriormente entender as "coisas" que a estratégia faz para o organismo, e o contexto onde essa função é desejada. Abstraídas as estratégias e definidas as funções do fruto do amendoim, geraram-se ideias para embalagens, porém com analogias muito próximas aos aspectos formais e estruturais, perceptíveis à "olho nú", do fruto do amendoim.

\section{2 .}

\section{Experimento B}

As novas tecnologias digitais estão provocando mudanças sísmicas nas economias mundiais. Elas oferecem uma nova forma de aproximação e abordagem para lidar com a complexidade dos dias atuais, pois permitem comunicação ágil em rede, visualização e análise de dados, mudança de modelo fabril e de manufatura, entre outros. (MIT Technology Review, 2015).

Como destacamos na introdução desta dissertação, as novas tecnologias vêm provocando grande avanço na Medicina por meio de obtenção e visualização de imagens bem definidas do corpo humano através de tecnologias não invasivas, como aquisição de imagens por ressonância magnética (RM) e tratamento digital 
para que sejam representadas tridimensionalmente por meio de impressoras 3D de alta precisão.

Durante alguns anos, a partir de seu invento em 1591, o microscópio foi um equipamento essencial para a investigação da natureza. $\mathrm{O}$ mais moderno atualmente é o microscópio eletrônico de varredura que é utilizado para observar detalhes da superfície de objetos sólidos e é capaz de ampliá-las em até 300 mil vezes. A imagem pode ser tridimensional e registrada em vídeos e fotografias.

Os biólogos usam esses equipamentos a fim de ampliar o conhecimento científico sobre células no corpo do ser vivo, fornecendo às áreas de anatomia, organografia, histoquímica e fitopatologia, subsídios que poderão ser utilizados em melhoramento vegetal.

Os engenheiros de materiais usam microtomógrafos para verificar falhas microestruturais de materiais, a porosidade de metais, e o comportamento de peças sob condições variadas de pressão, temperatura e umidade.

Os designers usam os mesmos equipamentos para se inspirar com a inteligência da natureza e aplicá-la em projetos de design. Marko Brajovic e Guto Requena são uns desses designers que usam novos paradigmas orgânicos (possíveis por meio de novas tecnologias) programando formas a partir de emoções e imagens em nanoescala da natureza. Guto Requena (2015), fala de seu trabalho da seguinte maneira: "Nós moldamos memórias através do uso experimental de tecnologias digitais. Nós amamos hibridismos, interação e a sobreposição entre o analógico e o numérico".

O Experimento B caracteriza-se pelo intenso uso de novas tecnologias digitais, como microtomógrafo e impressora 3D. Usou-se como base metodológica o pensamento Biomimético - Biologia para Projetar (Biomimicry 3.8, 2007), porém, diferentemente da metodologia usada pelo Biomimicry 3.8, não integrou-se princípios da vida à solução, ou seja, não fez-se a avaliação das ideias bioinspiradas usando os princípios da vida como um checklist. Também executou-se uma etapa de validação do conceito de design mais promissor para inovação de embalagem bioinspirada.

Como a Experimentação B foi realizada a partir do mesmo organismo inspirador (o fruto do amendoim), portanto, não foi necessário repetir as Etapas de descoberta de modelos naturais e seleção do organismo inspirador. A Experimentação B, portanto, abrangeu as seguintes Etapas: Abstrair estratégias 
biológicas (B1); Identificar função e definir contexto (B2); Brainstorm 1 primeiras ideias bioinspiradas (B3); Emular conceitos de design do brainstorm 1 (B4); Brainstorm 2 - novas ideias bioinspiradas (B5); Emular conceitos de design do brainstorm 2 (B6); Explorar e validar o conceito de design mais promissor para inovação de embalagem bioinspirada (B7).

A Etapa B1 consistiu em abstrair as estratégias biológicas usadas pelo amendoim para evoluir e sobreviver, por meio do uso intenso de novas tecnologias digitais de aquisição de imagens pela microtomografia, digitalização das mesmas e materialização por impressão 3D.

A Etapa B2 visou entender as funções do fruto do amendoim. Tratou-se de identificar uma característica, mecanismo, processo, que faz alguma coisa (uma função) para esse organismo. São as "coisas" que a estratégia faz para o organismo, e o contexto onde essa função é desejada. $\mathrm{O}$ uso das tecnologias digitais, nessa Etapa, permitiram uma nova abordagem mais reveladora, precisa e acurada para as funções relacionadas às abstrações biológicas da vagem do amendoim.

Mapeadas e refinadas as estratégias e funções do amendoim, e definido o contexto (embalagem), a próxima Etapa (B3) foi a de gerar ideias, combinando esses elementos para resolver problemas. Então, perguntou-se: que problemas pode-se resolver por analogias, ou seja, com a transferência de estratégias abstraídas do amendoim para o design de embalagem?

Para auxiliar nessa transferência, contou-se com a participação, em sessões criativas, de designers com habilidades em: desenho e sketches, uso de softwares para modelagem tridimensional (Rhinoceros e Solidworks), conhecimentos técnicos e práticos no uso de impressoras 3D (Cube Pro, Felix e Makerbot) para materialização por meio de prototipagem rápida.

A Etapa B4, baseada na Lente Biomimética para o Design "Biologia para Projetar" (Biomimicry 3.8, 2013), visou aprimorar as melhores ideias do brainstorm a fim de desenvolver conceitos de design. A emulação considera aspectos de forma, configuração, construção, estrutura, escala e padrões. Utilizou-se o software Solidworks e a impressora 3D Felix.

$\mathrm{Na}$ Etapa B5, outras sessões criativas foram realizadas e novas ideias geradas para o desenvolvimento de novos conceitos de design. Seguiu-se com a mesma metodologia, focando em explorar analogias com alvéolos observados na va- 
gem do amendoim para posterior transferência desse princípio para o design de embalagem.

As melhores ideias do brainstorm 2 foram selecionadas para aprimoramento, na Etapa B6. Considerou-se, portanto, aspectos de forma, configuração, construção, estrutura, escala e padrões para que as ideias evoluíssem para novos conceitos de design biomimético. Nessa etapa utilizou-se o software Solidworks e a impressora 3D Felix e Makerbot, usando filamentos PLA e NinjaFlex.

Finalmente na Etapa B7 os resultados promissores e surpreendentes obtidos com o conceito mais promissor encorajaram novas explorações conceituais e de desenvolvimento técnico para concretização do objetivo geral pretendido nessa pesquisa: desenvolver soluções conceituais inovadoras para embalagens de alimentos, a partir da Biomimética, apoiada por novas tecnologias digitais (microtomografia e impressão 3D).

\subsection{1.}

\section{Etapa B1: Abstrair estratégias biológicas}

No Experimento B, partiu-se da mesma inspiração biológica para o design de embalagem do Experimento A: o fruto do amendoim. Porém, procurou-se aprender sobre esse fruto utilizando-se de novas tecnologias digitais, a fim de gerar mais dados primários. São elas: aquisição de imagem por meio de microtomografia (software Scout and Scan Control System), reconstrução da imagem (software XM Reconstructor Cobe Beam 10), tratamento dessas imagens digitalmente (softwares Fiji e Geomagic), modelagem tridimensional (softwares Rhinoceros e Solidworks), prototipagem rápida em impressoras 3D. As impressoras 3D usadas nesta pesquisa foram: CubePro, Felix e MakerBot. Os filamentos utilizados foram PLA (Poliácido Lático - produzido a partir de fontes naturais como milho e canade-açúcar)), ABS (Copolímero de Acrilonitrila e Estireno) e NinjaFlex (Elastômero Termoplástico).

A microtomografia computadorizada é uma espécie de radiografia em 3D. Utiliza a mesma técnica da tomografia hospitalar, porém em pequena escala e com aumento exponencial da resolução. Seu diferencial é permitir uma visualização não destrutiva em 3D da estrutura interna de objetos.

Realizou-se, portanto, nesta etapa: (1.1) preparação dos corpos de prova biológicos para entrada no equipamento, (1.2) microtomografia com segmentação da 
imagem e (1.3) reconstrução da imagem; (1.4) e materialização por meio de prototipagem rápida.

Com o apoio de engenheiros no Laboratório de Engenharia de Materiais da PUC-Rio (LPDI) ${ }^{6}$, realizou-se a microtomografia dos seguintes materiais biológicos: Buriti, Clusia Lanceolata, Urucum e Amendoim.

Nas fotos abaixo, apresentamos o microtomógrafo do LPDI, durante seu uso no Experimento B. O equipamento usado foi o microtomógrafo Xradia 510 Versa, voltagem $80 \mathrm{Kv}, 7 \mathrm{~W}, 1601$ projeções, tempo de exposição 0.3 s e Binning 2, com tempo total de varredura de $1.3 \mathrm{hs}$.

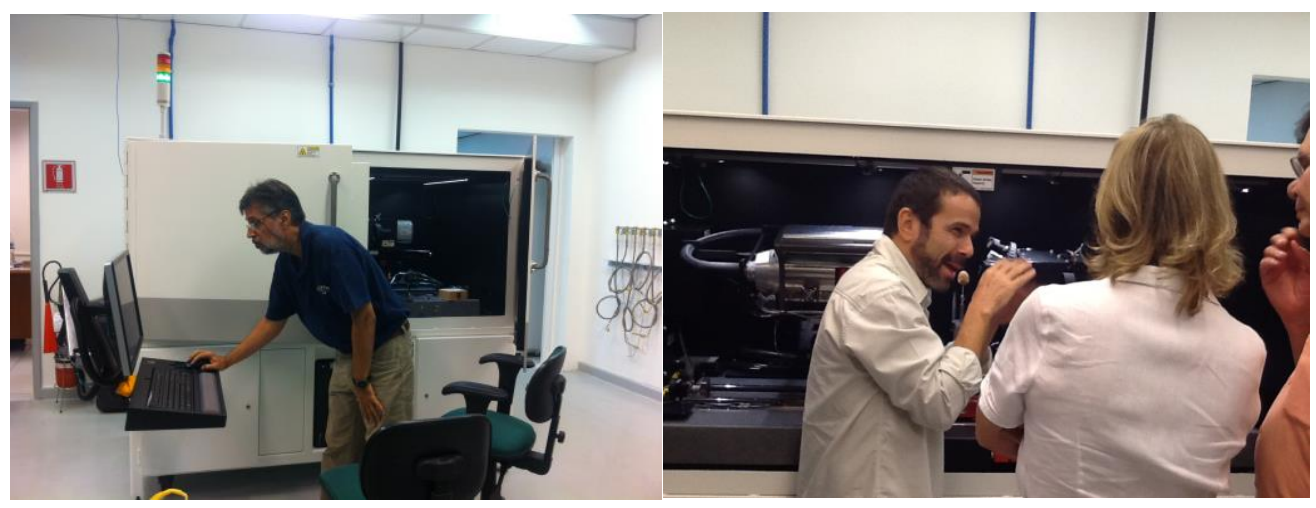

Figura 55 - Microtomógrafo LPDI e da equipe do LPDI durante a microtomografia dos materiais dessa pesquisa (fotos da autora).

Os primeiros materiais biológicos microtomografados no experimentro B, forma coletados no Jardim Botânico do Rio de Janeiro, analisados superficialmente no Next e encaminhados ao LPDI para aquisição de imagens por meio de microtomografia. A aquisição de imagens de diversos materiais coletados serviu para teste e calibragem do microtomógrafo com materiais biológicos, uma vez que seu uso geral no LPDI é a aquisição de imagens de materiais inorgânicos, tais como pelotas de minério, aço, etc... É importante frisar o uso inovador desse equipamento na aquisição de imagens de materiais biológicos.

Nas fotos abaixo, apresenta-se os seguintes materiais e suas correspondentes imagens geradas no microtomógrafo: Urucum e Clusia Lanceolata.

\footnotetext{
${ }^{6}$ Sidnei Paciornik, Doutor em Física e professor associado do Departamento de Engenharia Química e de materiais (DEQM) da Puc-Rio. Responsável pelo Laboratório de Processamento Digital de Imagens (LPDI) e Marcos Henrique de P. Maurício, Doutor em Engenharia Metalúrgica engenheiro de pesquisa no Departamento de Engenharia de Materiais da PUC-Rio
} 


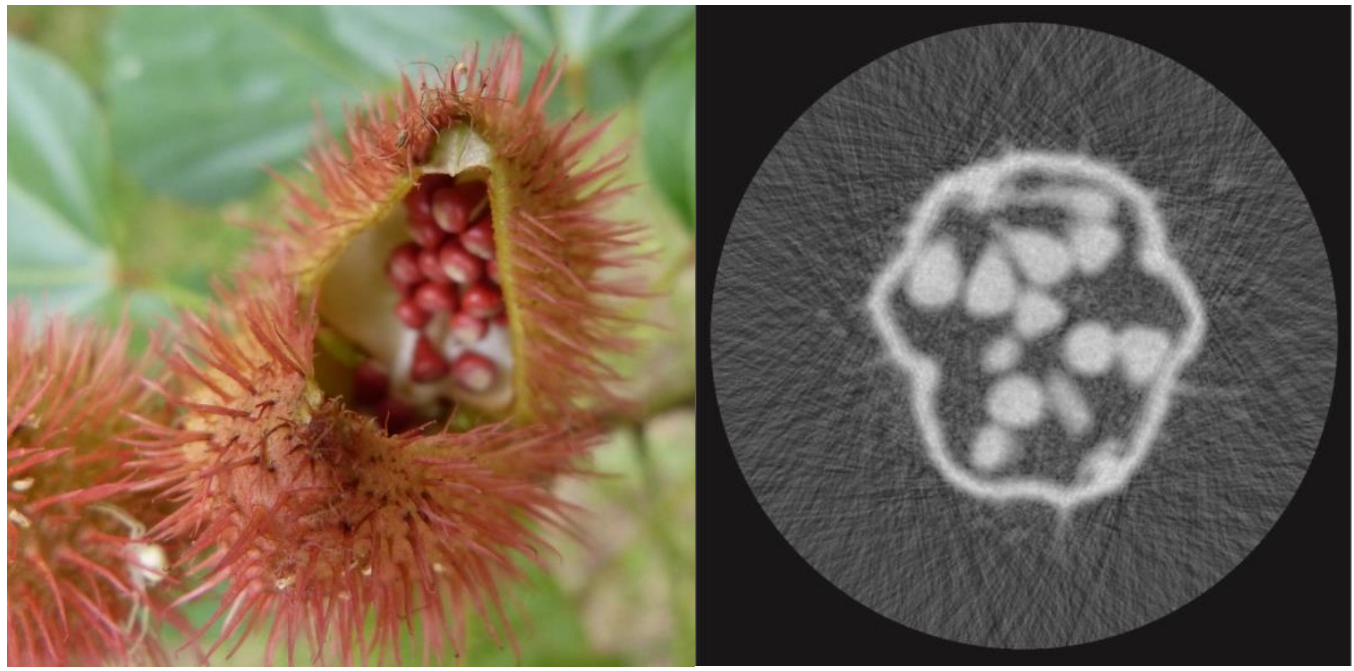

(a)

(b)

Figura 56 - Urucum no arboreto do JBRJ (a) e sua visualização (uma camada) em microtomógafo (b) (fotos da autora).

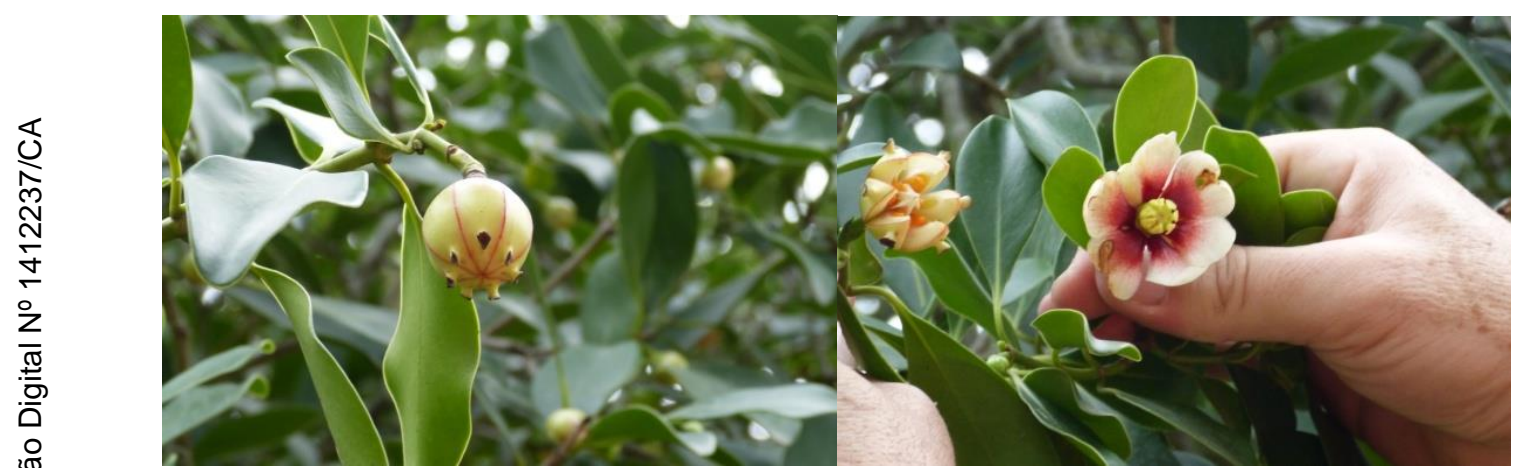

Figura 57 - Clusia Lanceolata (fruto fechado e aberto e flor) no arboreto do JBRJ (fotos da autora).

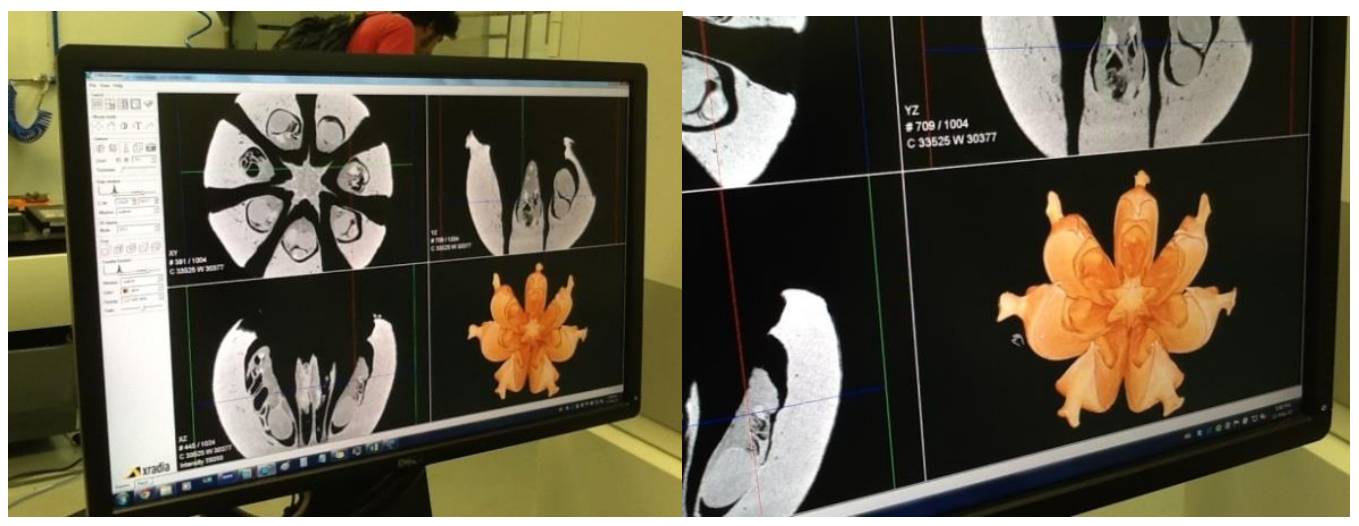

Figura 58 - Clusia Lanceolata (fruto) e sua visualização 3D em microtomógafo (fotos da autora).

Após calibragem do equipamento para materiais biológicos, microtomografou-se a vagem do amendoim. 
As amostras de amendoins passaram por um processo de preparação: (1) seleção quanto a sua integridade física e (2) fixação a suportes internos do equipamento (para garantir bom resultado de imagem).

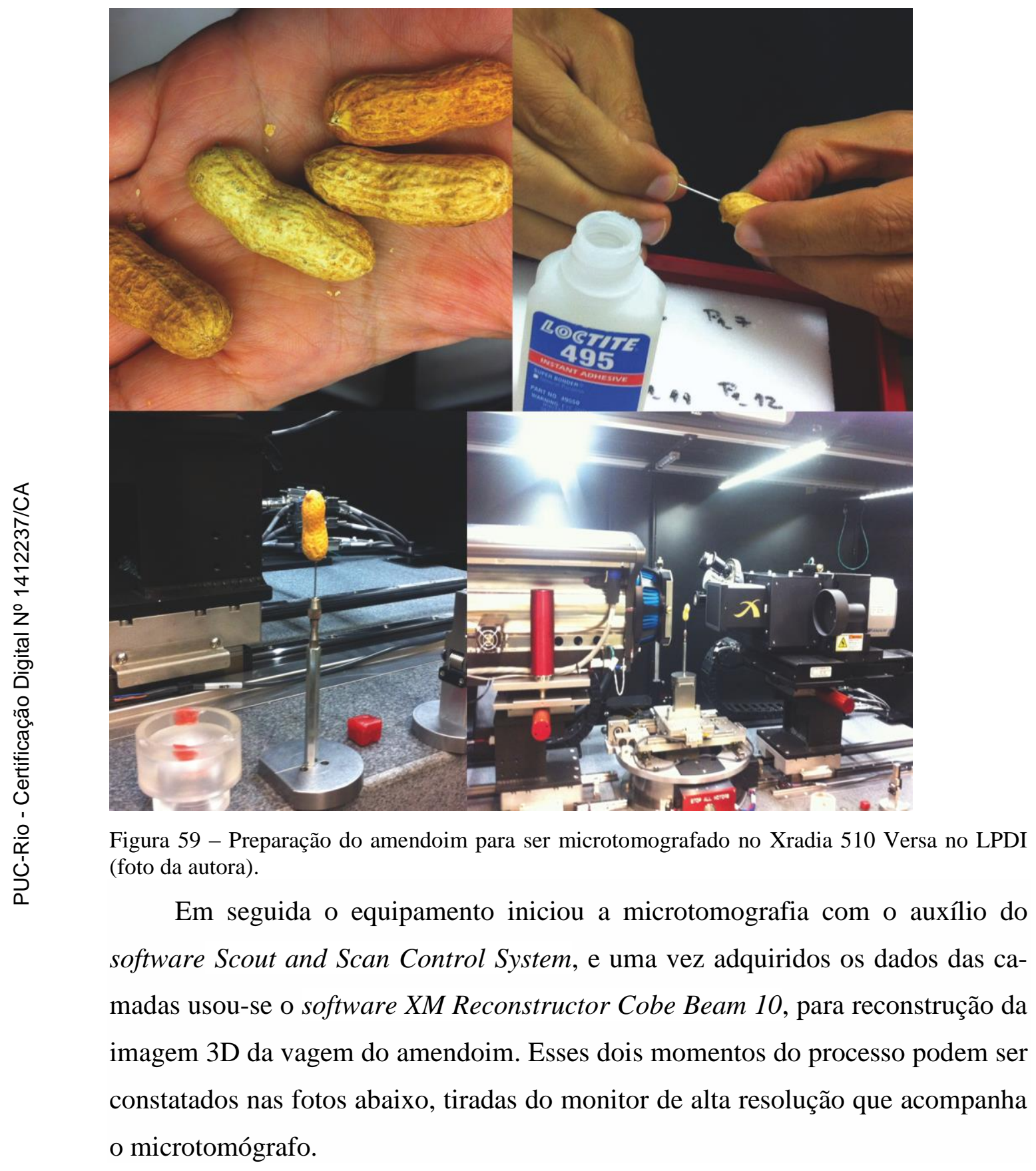




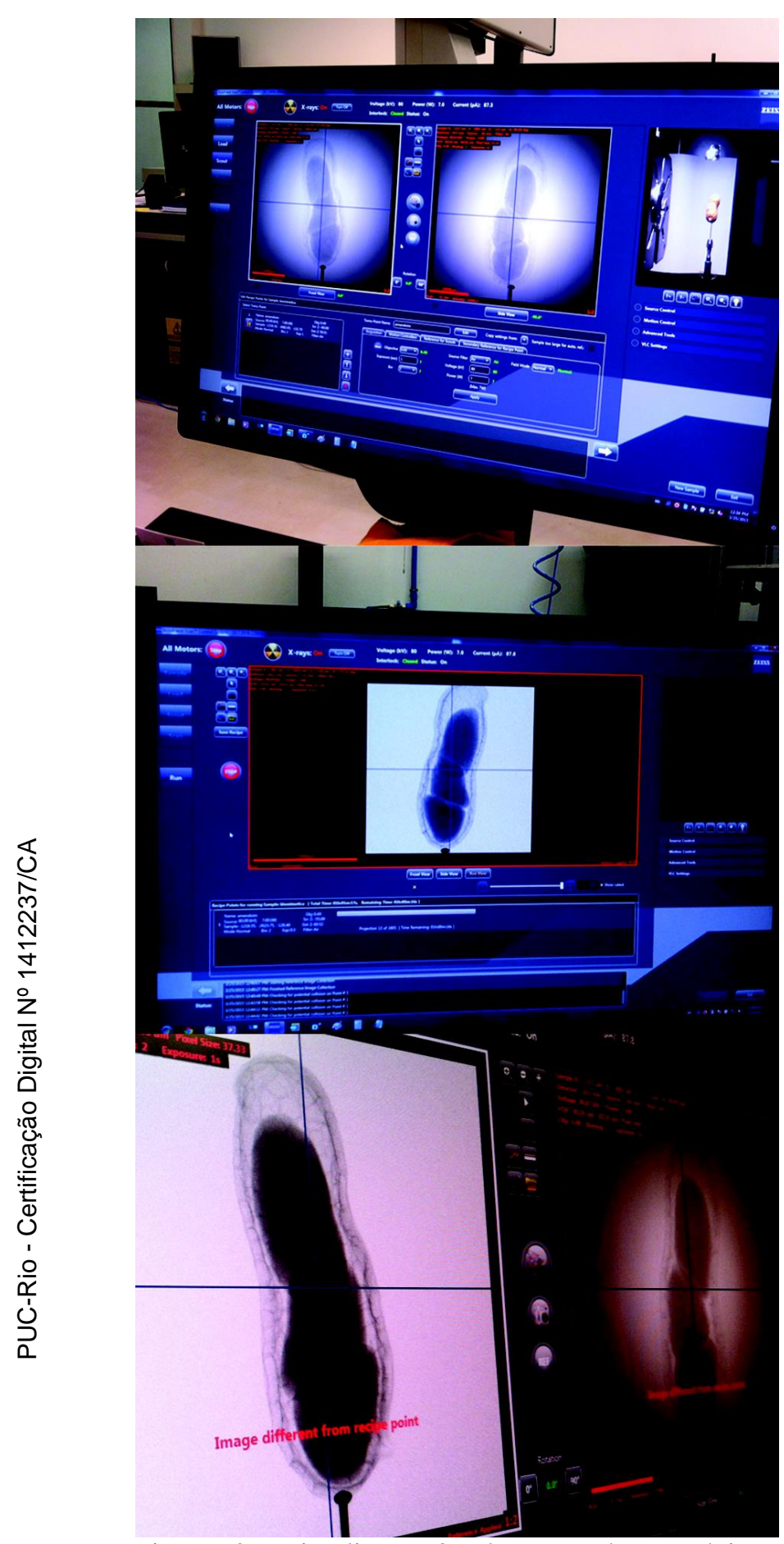

Figura 60 - Visualização 3D da vagem do amendoim microtomografado no Xradia 510 Versa no LPDI (foto da autora). 


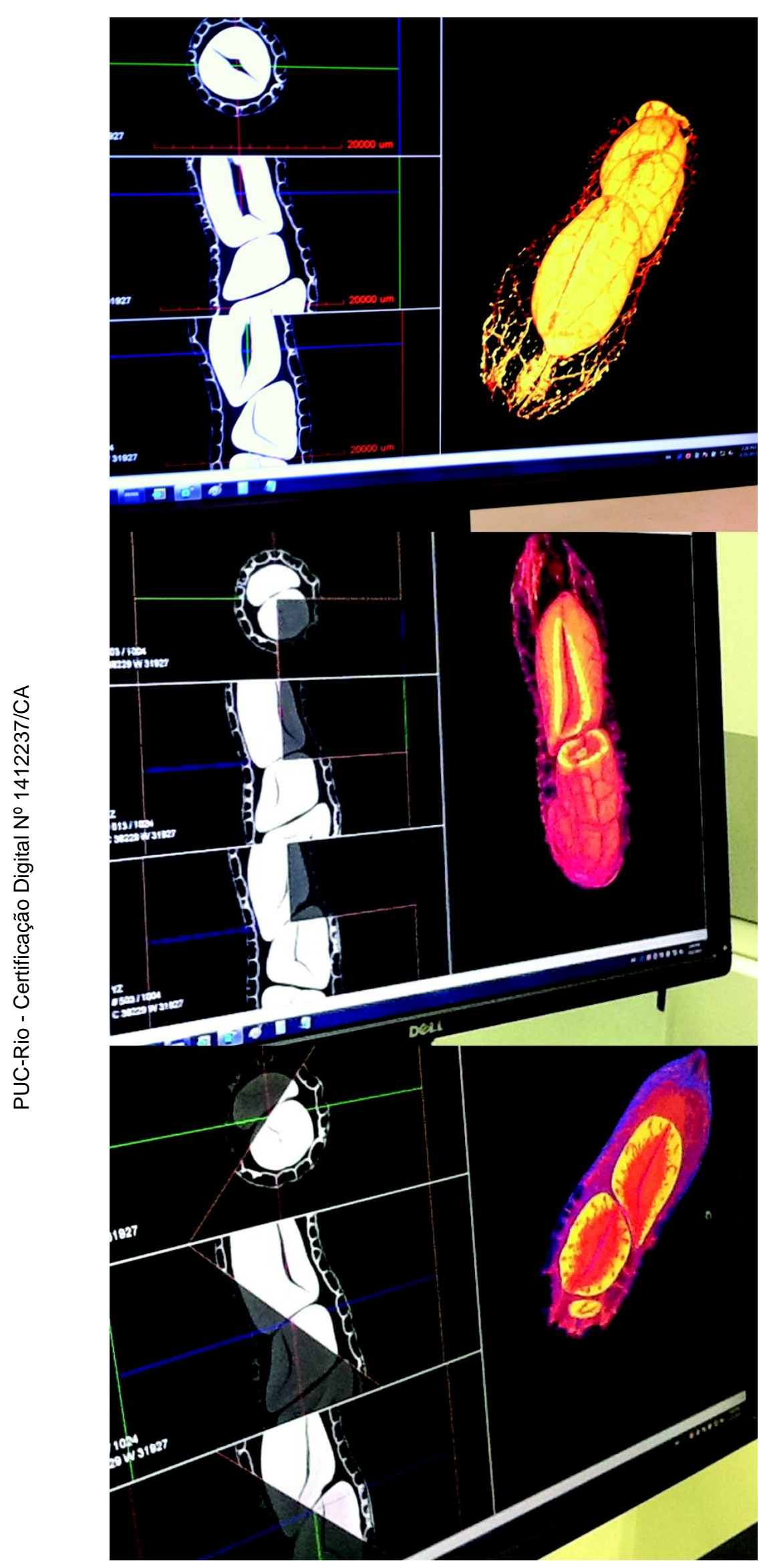

Figura 61 - Visualização 3D da vagem do amendoim microtomografado no Xradia 510 Versa no LPDI (fotos da autora). 
Já de posse dos dados primários adquiridos com o microtomógrafo e visualizados com o auxílio do software Scout and Scan Control System, conseguiu-se analisar com detalhes a estrutura do conjunto, de forma não invasiva, ou seja, sem alterar a integridade da vagem. As fotos abaixo são resultado da manipulação das imagens no Laboratório de Experimentação Tridimensional do Departamento de Artes e Design Puc-Rio (NEXT) com o auxílio dos softwares Mimics e Fiji.

Observa-se, na montagem abaixo, a sequência de dados primários com imagens segmentadas em camadas transversais, de uma vagem de amendoim.

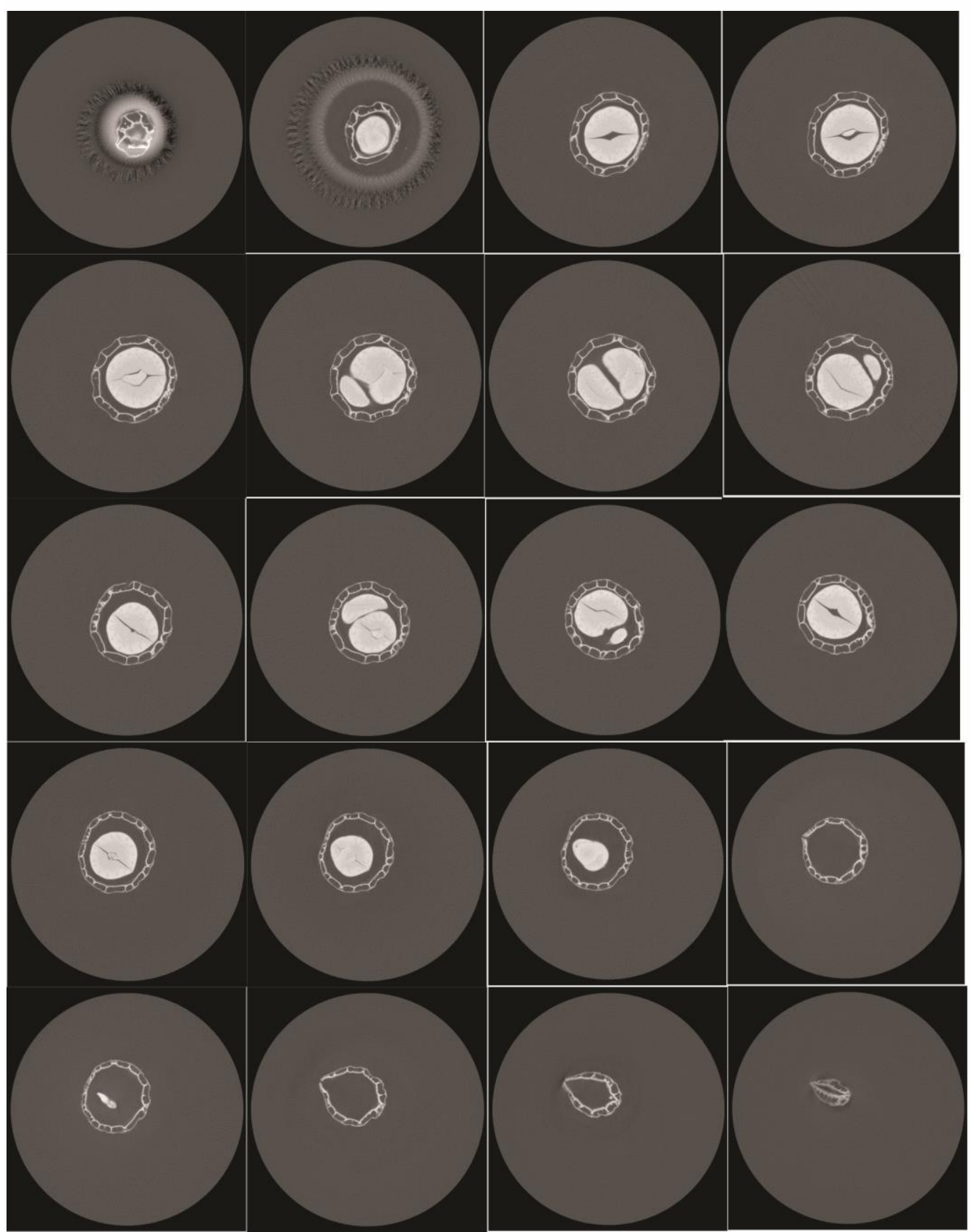

Figura 62 - Imagens adquiridas no microtomógrafo com a sequência de camadas da vagem do amendoim, usando-se o software Mimics (montagem da autora) 


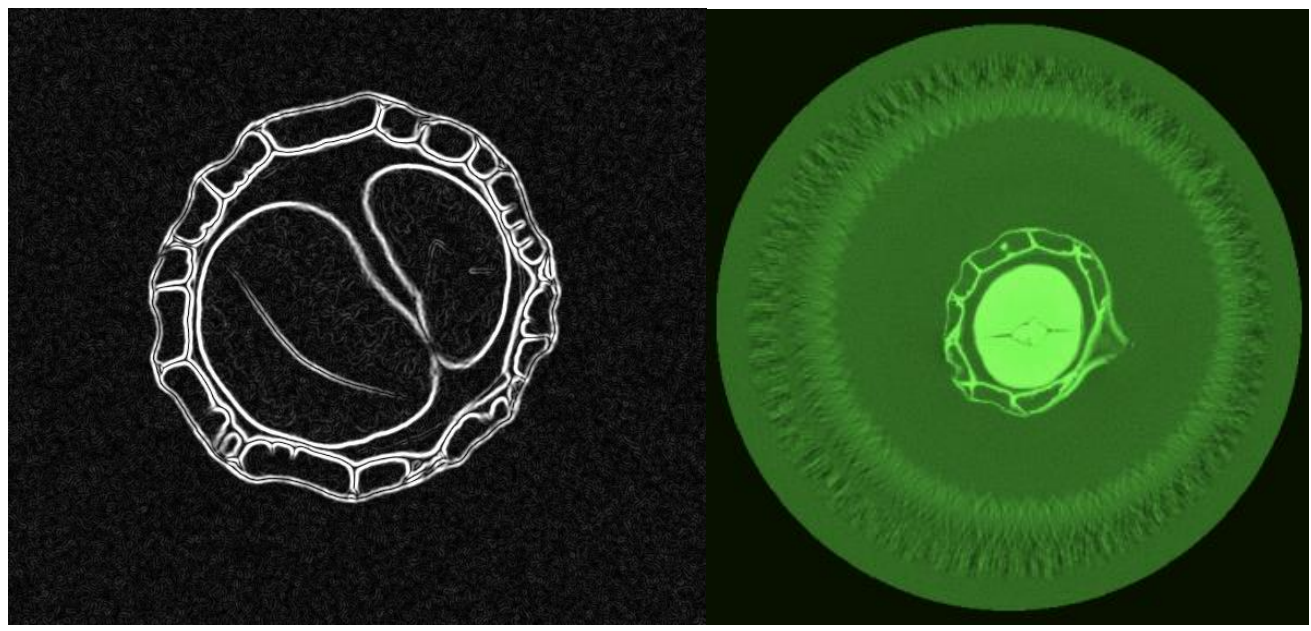

Figura 63 - Imagens adquiridas no microtomógrafo com a sequência de camadas da vagem do amendoim, usando-se o software Fiji (montagem da autora).

As imagens adquiridas com o microtomógrafo revelaram o que não tinha-se conseguido observar a "olho nú": que a estrutura da casca da vagem do amendoim é alveolar e não multicamadas com depressões, como inferiu-se no Experimento A (sem uso de novas tecnologias). Dessa forma compreendeu-se que devido à estrutura alveolar a casca é leve e ao mesmo tempo resistente.

Na montagem abaixo compara-se: o desenho representativo da observação a "olho nú" do amendoim (com as fibras, multicamadas e depressões); e as imagens do mesmo adquiridas com o microtomógrafo, nas quais pode-se constatar a estrutura alveolar da casca.

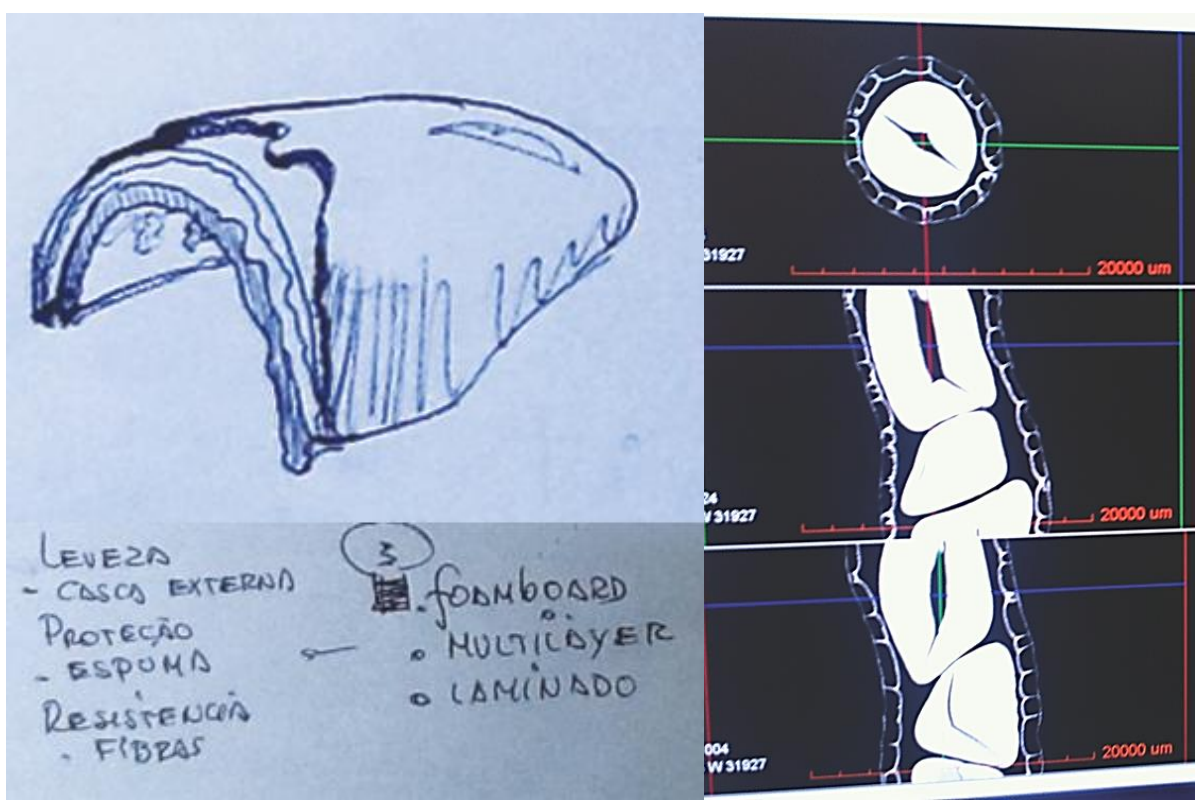

(a)

(b)

Figura 64 - Comparação entre representação da casca do amendoim após observação a "olho nú" (a) e imagens adquiridas pelo microtógrafo do amendoim, evidenciando sua estrutura alveolar (b) (fotos da autora). 


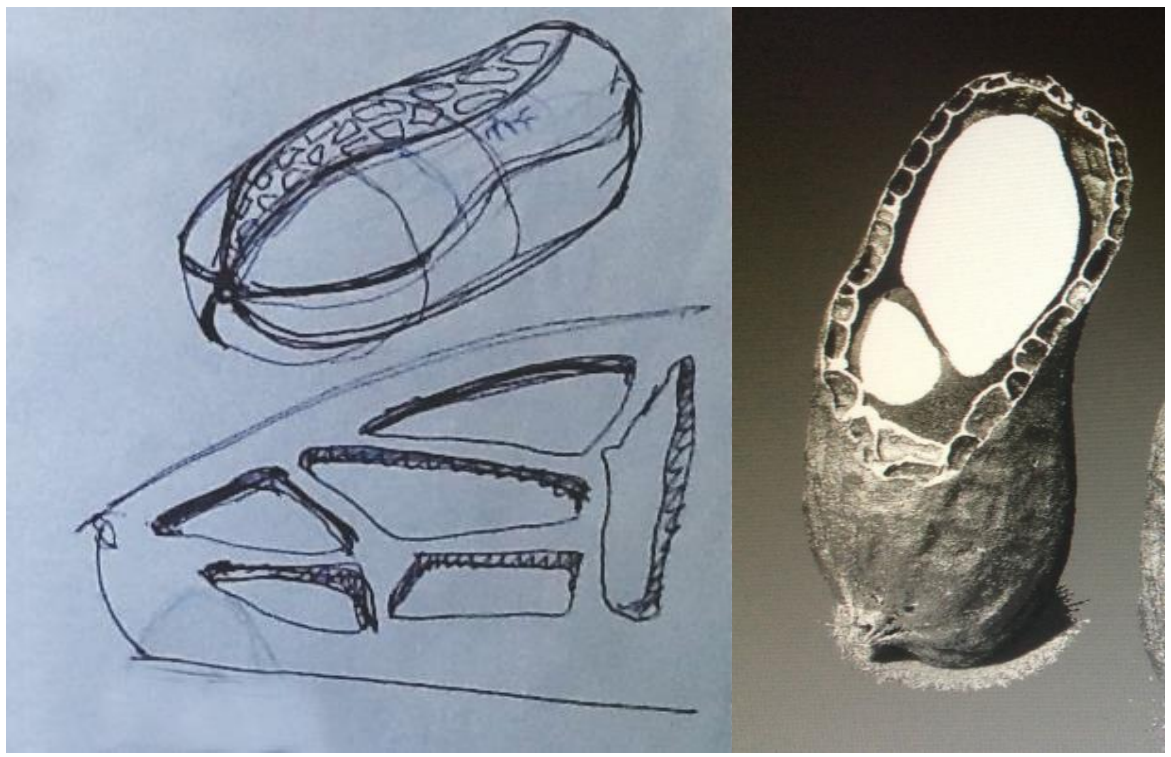

(a)

(b)

Figura 65 - Comparação entre: representação da casca do amendoim após observação a "olho nú" (a) e imagens adquiridas pelo microtógrafo do amendoim, evidenciando sua estrutura alveolar (b) (fotos da autora).

Também foi possível observar a partir da microtomografia (de forma não invasiva, ou seja, sem quebrar a casca), duas áreas de fragilidade caracterizadas por fendas ao longo do sentido longitudinal da vagem, que anteriormente identificou-se como uma área de "quebra", porém sem dados conclusivos que explicassem a fragilidade dessa região. Com ajuda das imagens confirmou-se que essa fragilidade era em função das fendas (uma espécie de "soldagem" do carpelo da vagem no processo de crescimento, portanto com pouco material e estrutura) presentes na casca.

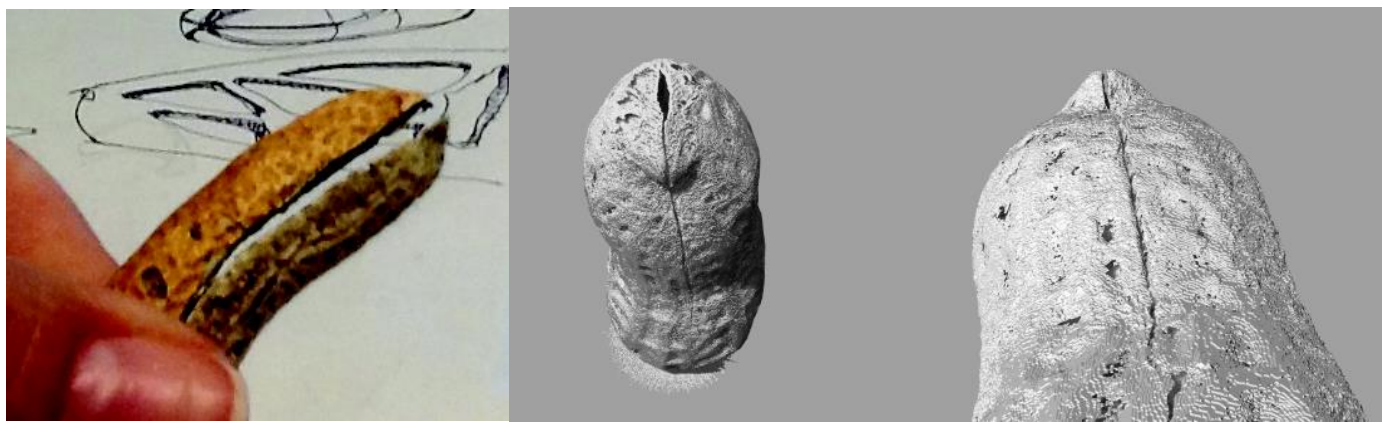

(a)

(b)

Figura 66 - Vagem do amendoim observada a "olho nú" após ser quebrada (a) e imagem microtomografada em que verificou-se de forma não invasiva a fragilidade da área de soldagem dos carpelos (b) (foto da autora). 


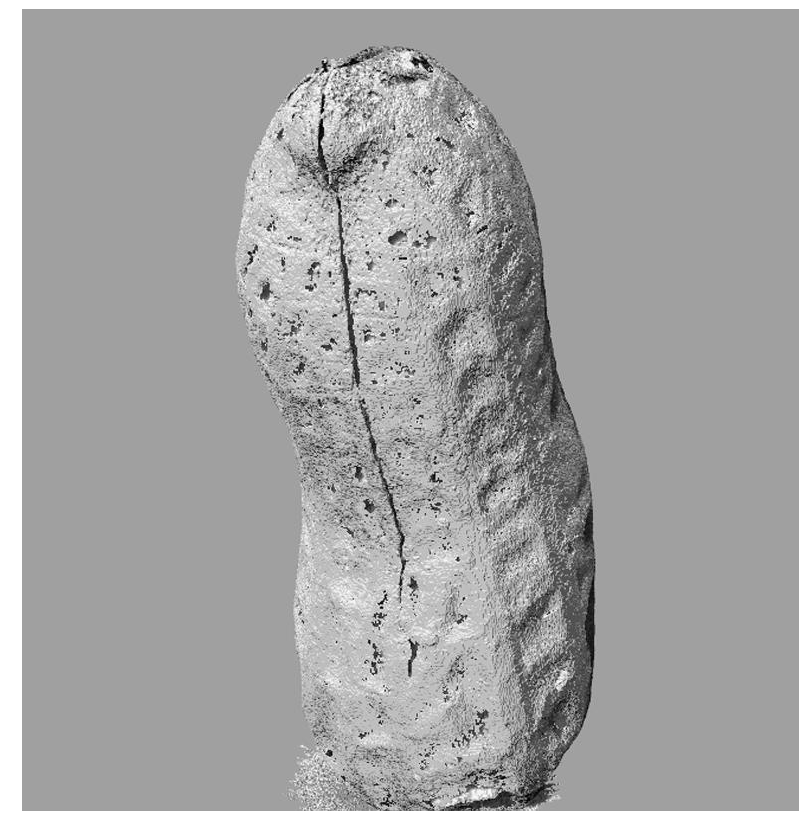

Figura 67 - Visualização 3D da vagem do amendoim, a partir de dados primários adquiridos na microtomografia, evidenciando duas fendas logitudinais, configurando uma área de fragilidade na casca. Imagem digitalizada no software Rhinoceros (foto da autora).

Com as imagens geradas no microtomógrafo e nas digitalizações (Figuras 67, 68 e 69), teve-se mais facilidade em analisar o conjunto, principalmente a estrutura construtiva da casca, e desta forma refinar a abstração de estratégias biológicas.

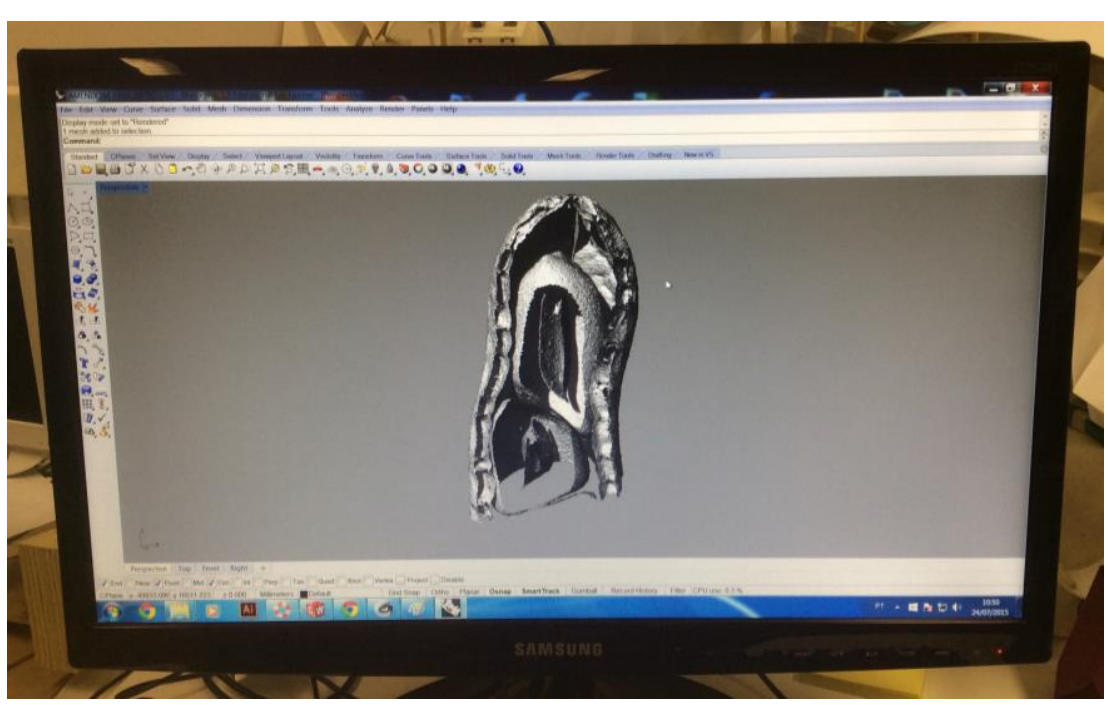

Figura 68 - Visualização 3D da vagem amendoim (corte longitudinal), evidenciando sua estrutura alveolar. Imagem digitalizada no software Rhinoceros (foto da autora). 


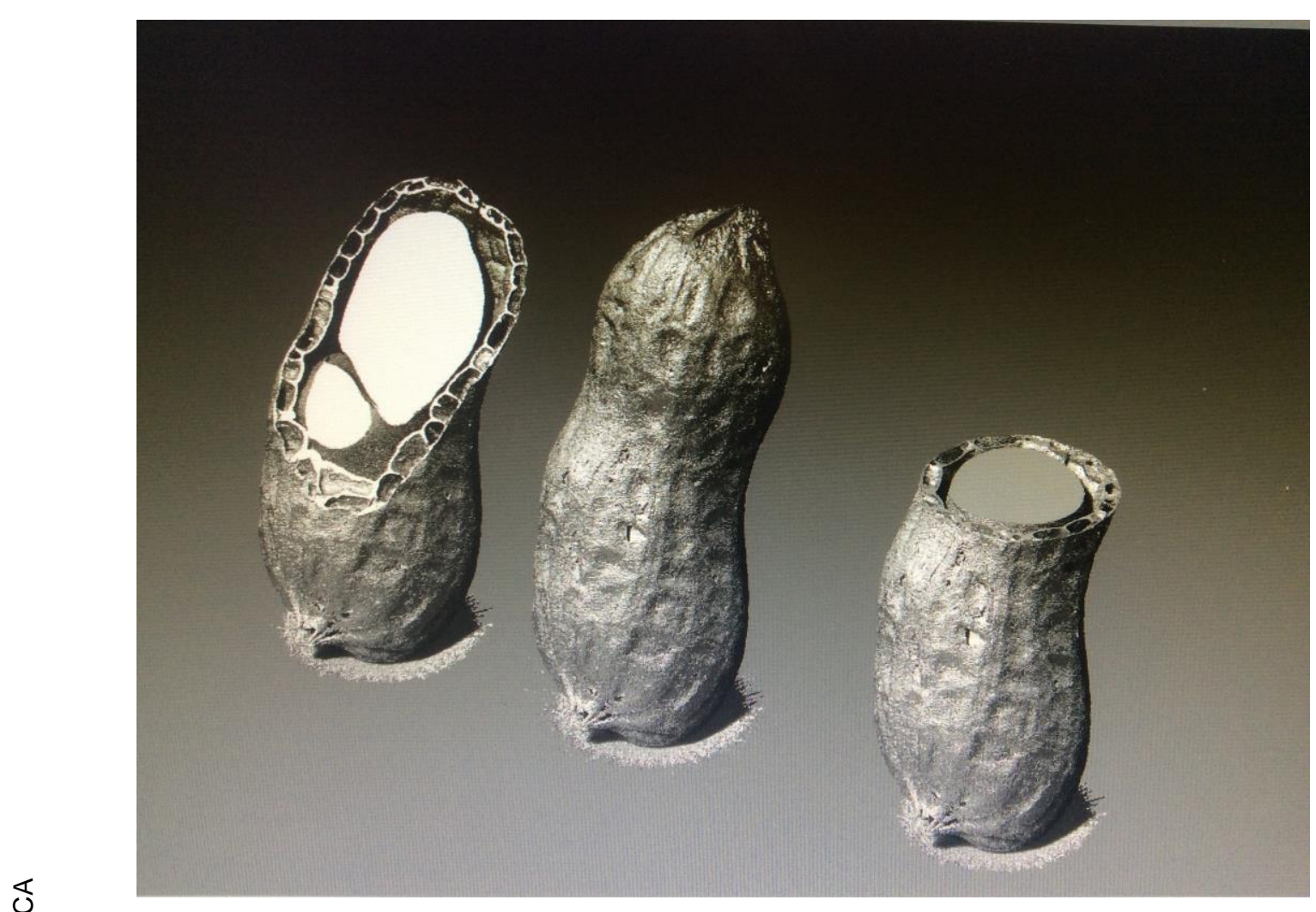

Figura 69 - Visualização 3D da vagem do amendoim. Corte transversal evidenciando estrutura alveolar. Imagem digitalizada no software Rhinoceros (foto da autora).

Diversos desenhos esquemáticos foram gerados a fim de representar a estrutura alveolar e conduzir novas buscas por dados primários para refinar a abstração das estratégias biológicas do fruto do amendoim. (Figura 70).

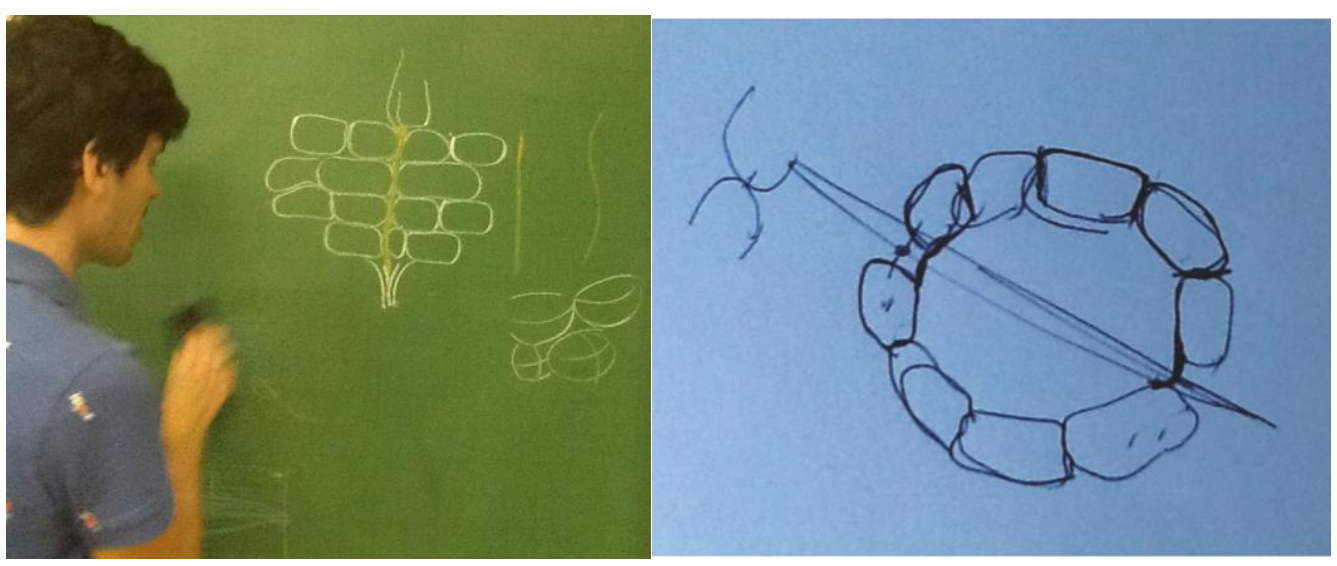

Figura 70 - Desenhos representando a estrutura alveolar da casca do amendoim e as fendas longitudinais (fotos da autora). 

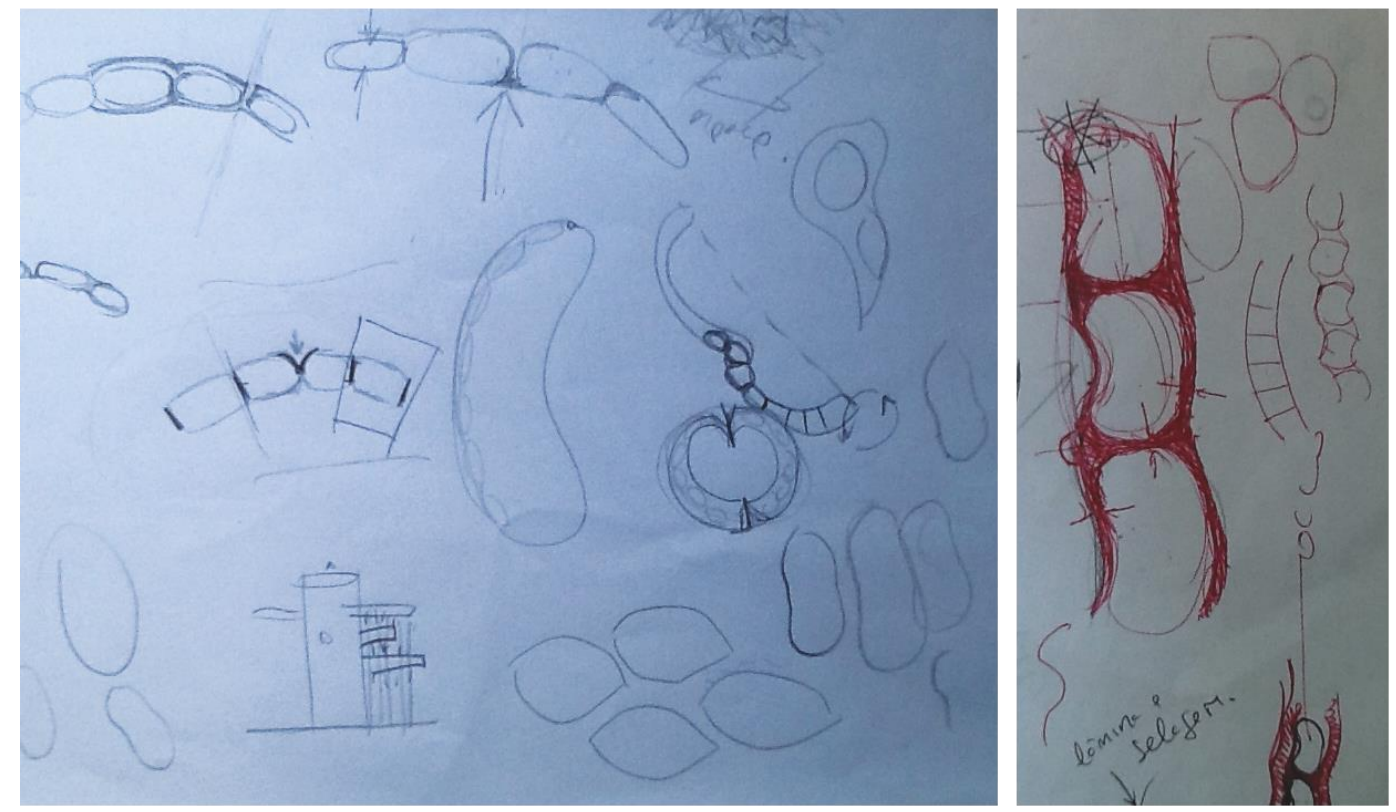

Figura 71 - Representação da estrutura alveolar da casca do amendoim (desenho da autora).

As imagens digitalizadas no software Rhinoceros (Figura 72) foram expor-

tadas (com o formato .stl) para realizar uma prototipagem rápida de uma seção do amendoim em escala ampliada (impressora CubePro).

Esse experimento de aumento de escala do arquivo da casca da vagem e a materialização da mesma em impressoras 3D (Figura 73) teve o propósito de examinar em detalhes a estrutura alveolar, a fim de perceber com mais clareza a configuração dos alvéolos nas duas direções da casca.

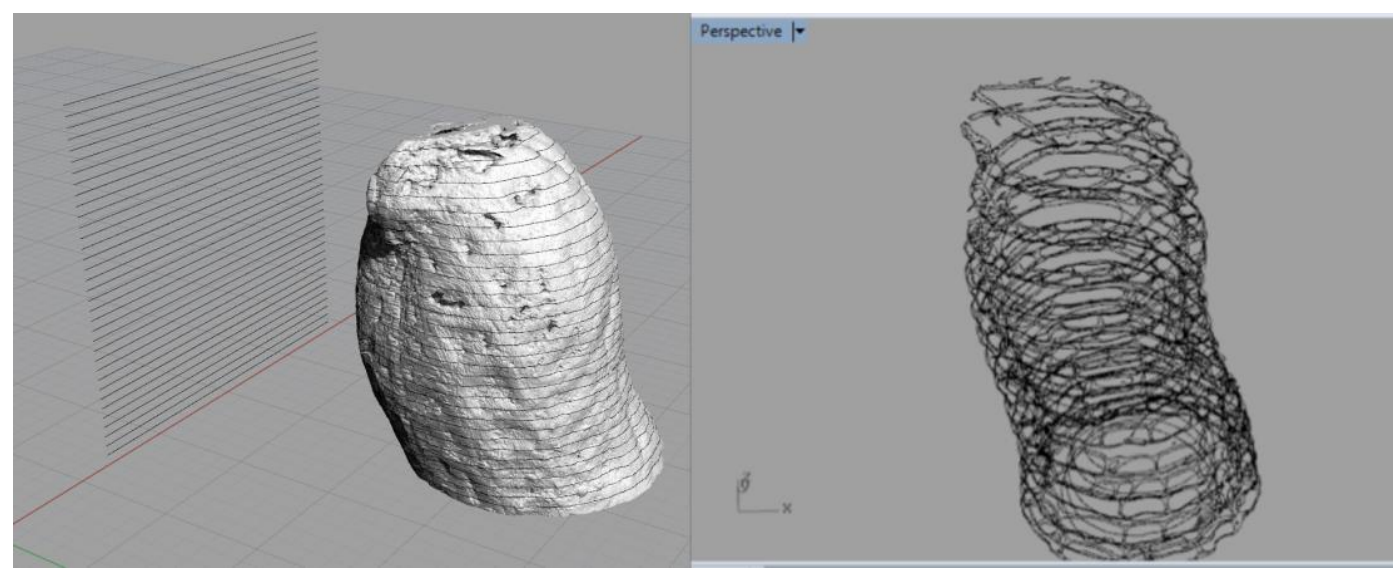

Figura 72 - Seção do amendoim digitalizada no software Rhinoceros e preparação para exportação do arquivo para a impressora 3D (foto da autora). 


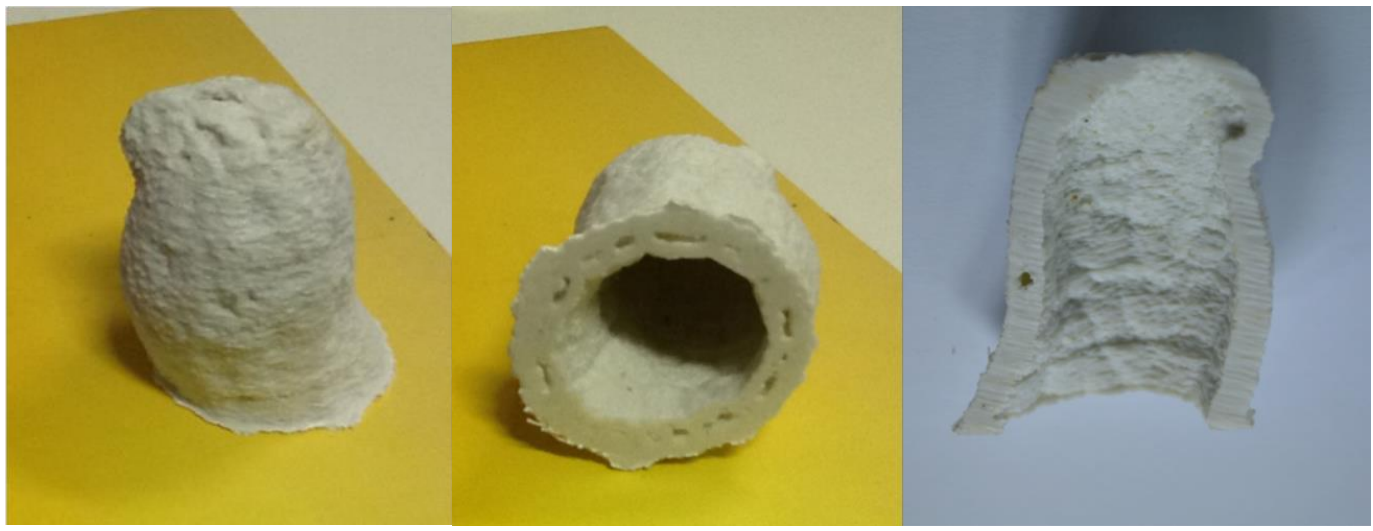

Figura 73 - Materialização, por meio de prototipagem rápida, da seção da vagem do amendoim em escala ampliada, impressa na CubePro com filamento ABS (foto da autora).

Abaixo a impressora CubePro iniciando o processo de impressão 3D com o filamento ABS.

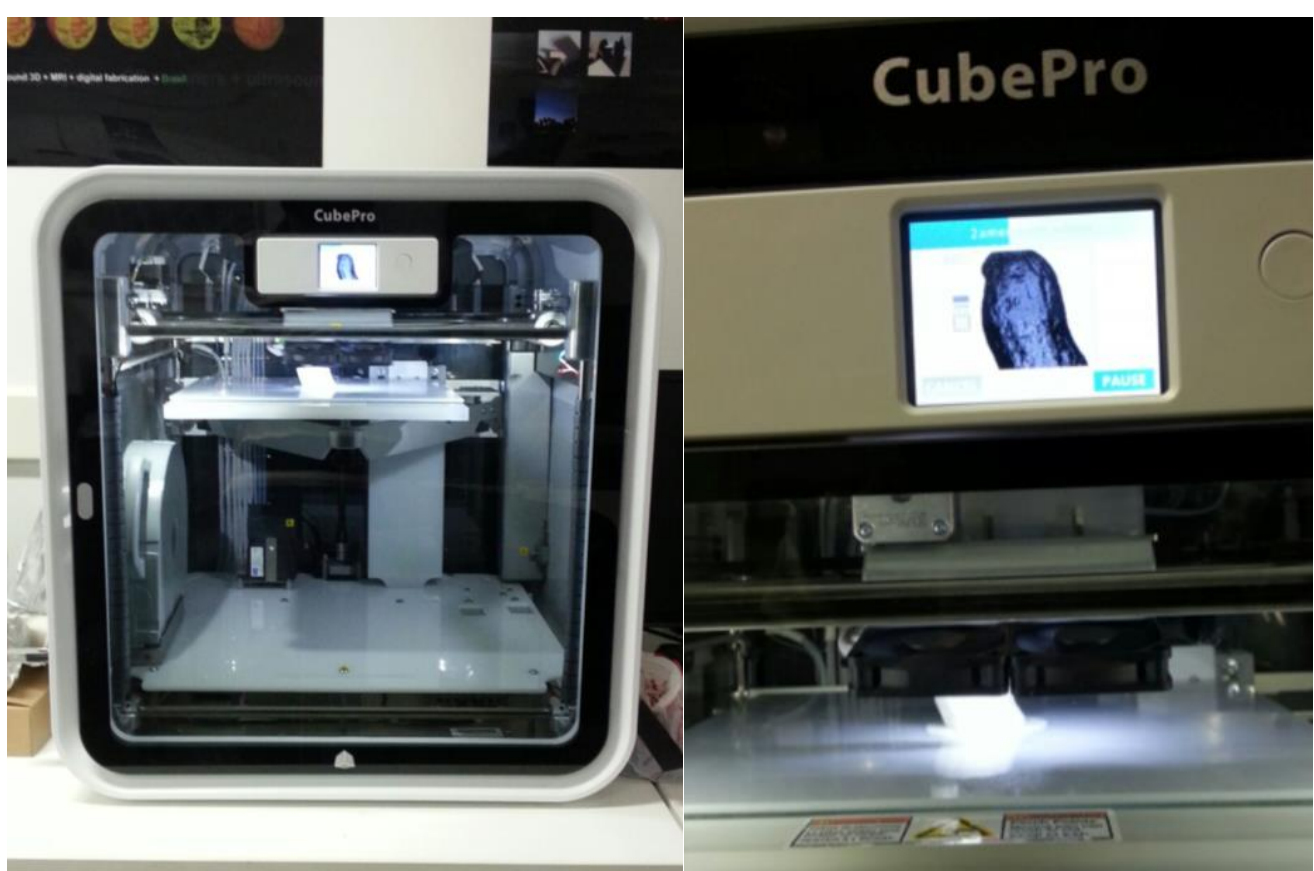

Figura 74 - Impressora CubePro iniciando a impressão do arquivo de seção da vagem do amendoim em escala ampliada (fotos da autora no NEXT).

Os processos realizados e descritos acima (aquisição de imagens pela microtomografia, digitalização das mesmas e materialização por impressão 3D) permitiram uma investigação detalhada, precisa e acurada da vagem do amendoim, ampliando nossa visão e conhecimento por meio da aquisição de dados primários propiciada pelas novas tecnologias, colaborando, enfim, para o refinamento das estratégias biológicas abstraídas no ponto 4.1.3 dessa dissertação. 
Os principais refinamentos relacionaram-se à constatação (a partir da microtomografia) da presença de alvéolos e de duas fendas longitudinais na casca da vagem. No quadro abaixo compara-se as estratégias observadas antes do uso das novas tecnologias (Experimento A) e depois do uso das novas tecnologias (Experimento $\mathrm{B})$.

\section{VAGEM DO AMENDOIM}

\begin{tabular}{|c|c|}
\hline $\begin{array}{l}\text { Estratégias biológicas abstraídas: } \\
\text { Experimento A (sem novas tecnologias) }\end{array}$ & $\begin{array}{l}\text { Estratégias biológicas abstraídas: } \\
\text { Experimento B (com novas tecnologias) }\end{array}$ \\
\hline Forma integral, adaptável a diferentes quantidades de sementes. & Forma integral, adaptável a diferentes quantidades de sementes. \\
\hline $\begin{array}{l}\text { Fragilidade na região longitudinal da vagem, } \\
\text { que "quebra" por meio de pressão, } \\
\text { disponibilizando as sementes sem danificá-las. }\end{array}$ & $\begin{array}{l}\text { Fragilidade em função de duas fendas presentes na casca na região } \\
\text { longitudinal da vagem (uma espécie de "soldagem" do carpelo da } \\
\text { vagem no processo de crescimento), que "quebra" por meio de } \\
\text { pressão intencional localizada, disponibilizando as sementes } \\
\text { sem danificá-las. }\end{array}$ \\
\hline $\begin{array}{l}\text { Amadurecimento do fruto embaixo da terra, } \\
\text { permitindo proteção contra predadores. }\end{array}$ & $\begin{array}{l}\text { Amadurecimento do fruto embaixo da terra, } \\
\text { permitindo proteção contra predadores. }\end{array}$ \\
\hline Impermeabilidade & Impermeabilidade \\
\hline $\begin{array}{l}\text { Casca rígida, composta por conjunto de fibras longitudinais e } \\
\text { multicamadas de materiais. }\end{array}$ & $\begin{array}{l}\text { Casca rígida, composta por estrutura alveolar, fibras longitudinais } \\
\text { e multicamadas de materiais. }\end{array}$ \\
\hline \multirow[t]{2}{*}{ Casca leve, devido à diminuição da espessura nas depressões. } & Casca leve, devido à estrutura alveolar. \\
\hline & $\begin{array}{l}\text { Propriedades de barreira da casca contra agentes externos } \\
\text { aumentadas em função da estrutura alveolar (presença de ar que } \\
\text { é isolante). }\end{array}$ \\
\hline
\end{tabular}

\subsection{2.}

\section{Etapa B2: Identificar a função e definir contexto}

A etapa de descobrir modelos naturais do Experimento B usou novas tecnologias digitais como apresentado no ponto 4.2.1 dessa dissertação (aquisição de imagens pela microtomografia, digitalização das mesmas e materialização por impressão 3D).

Constatou-se que as novas tecnologias usadas no Experimento B permitiram uma investigação não invasiva, não destrutiva, detalhada, reveladora, precisa e acurada da vagem do amendoim, ampliando nossa visão e conhecimento por meio da aquisição de dados da vagem do amendoim, colaborando, enfim, para o refinamento das abstrações de estratégias biológicas realizadas no Experimento A. 
O quadro abaixo apresenta as funções refinadas a partir do uso de novas tecnologias.

\section{VAGEM DO AMENDOIM}

\begin{tabular}{|l|l|}
\hline Estratégias biológicas abstraídas & Funções \\
\hline Forma integral, adaptável a diferentes quantidades de sementes. & Permitir adaptações dimensionais \\
\hline $\begin{array}{l}\text { Fragilidade em função de duas fendas presentes na casca na região } \\
\text { longitudinal da vagem (uma espécie de "soldagem" do carpelo da } \\
\text { vagem no processo de crescimento), que "quebra" por meio de } \\
\text { pressão intencional localizada, disponibilizando as sementes } \\
\text { sem danificá-las. }\end{array}$ & $\begin{array}{l}\text { Abrir uniformemente por meio de pressão } \\
\text { localizada, permitindo acesso ao conteúdo } \\
\text { quando desejado e sem danificá-lo. }\end{array}$ \\
\hline $\begin{array}{l}\text { Amadurecimento do fruto embaixo da terra, } \\
\text { permitindo proteção contra predadores. }\end{array}$ & $\begin{array}{l}\text { Promover segurança ao conteúdo contra } \\
\text { agentes externos. }\end{array}$ \\
\hline $\begin{array}{l}\text { Impermeabilidade } \\
\text { Casca rígida, composta por estrutura alveolar, fibras longitudinais } \\
\text { e multicamadas de materiais. }\end{array}$ & $\begin{array}{l}\text { Resistir a quedas, amassamentos, torção, } \\
\text { punção e impacto, utilizando-se o mínimo de } \\
\text { material }\end{array}$ \\
\hline $\begin{array}{l}\text { Casca leve, devido à estrutura alveolar. } \\
\text { Propriedades de barreira da casca contra agentes externos } \\
\text { aumentadas em função da estrutura alveolar (presença de ar que }\end{array}$ & \begin{tabular}{l} 
Ser leve e ao mesmo tempo resistente \\
\hline Preservar por mais tempo o conteúdo
\end{tabular} \\
\hline
\end{tabular}

Quadro 6 - Abstrações biológicas da vagem do amendoim e funções refinadas (quadro da autora).

\subsection{3.}

\section{Etapa B3: Brainstorm 1 - primeiras ideias bioinspiradas}

Mapeadas e refinadas as estratégias e funções do amendoim, e definido o contexto (embalagem), a próxima etapa foi a de gerar ideias, combinando esses elementos para resolver problemas. Então, perguntou-se: que problemas pode-se resolver por analogias, ou seja, com a transferência de estratégias abstraídas do amendoim para o design de embalagem?

Para auxiliar nessa transferência, contou-se com a participação, em sessões criativas, de designers com habilidades em: desenho e sketches, uso de softwares para modelagem tridimensional (Rhinoceros e Solidworks), conhecimentos técnicos e práticos no uso de impressoras 3D (Cube Pro, Felix e Makerbot) para materialização por meio de prototipagem rápida. 
As sequências de desenhos abaixo (sketches à mão e modelados em computador) foram realizadas nessas sessões criativas, que geraram inúmeras ideias.

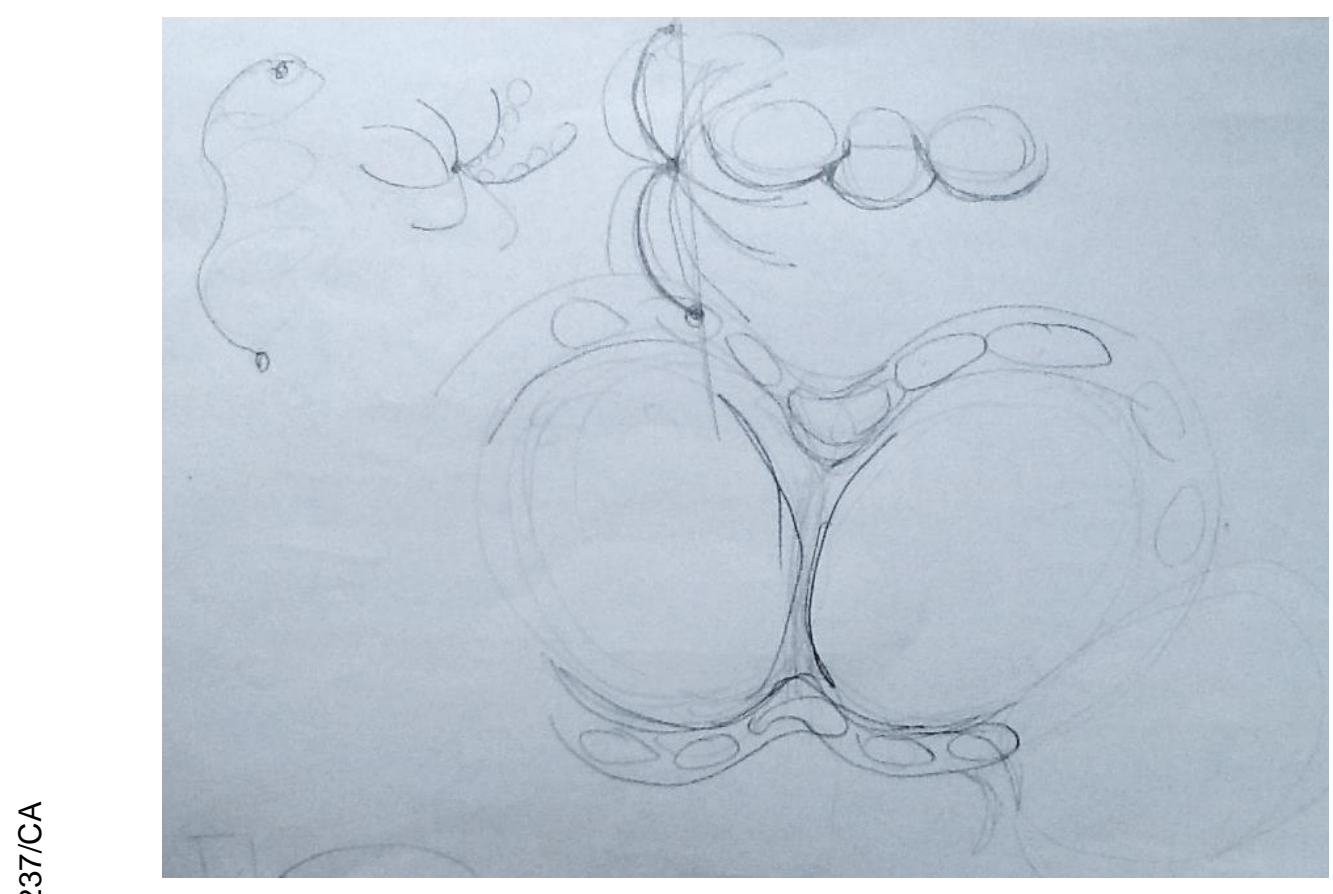

Figura 75 - Desenho à mão livre representando ideia para embalagem, usando analogia com a estrutura alveolar da vagem do amendoim (desenho da autora).

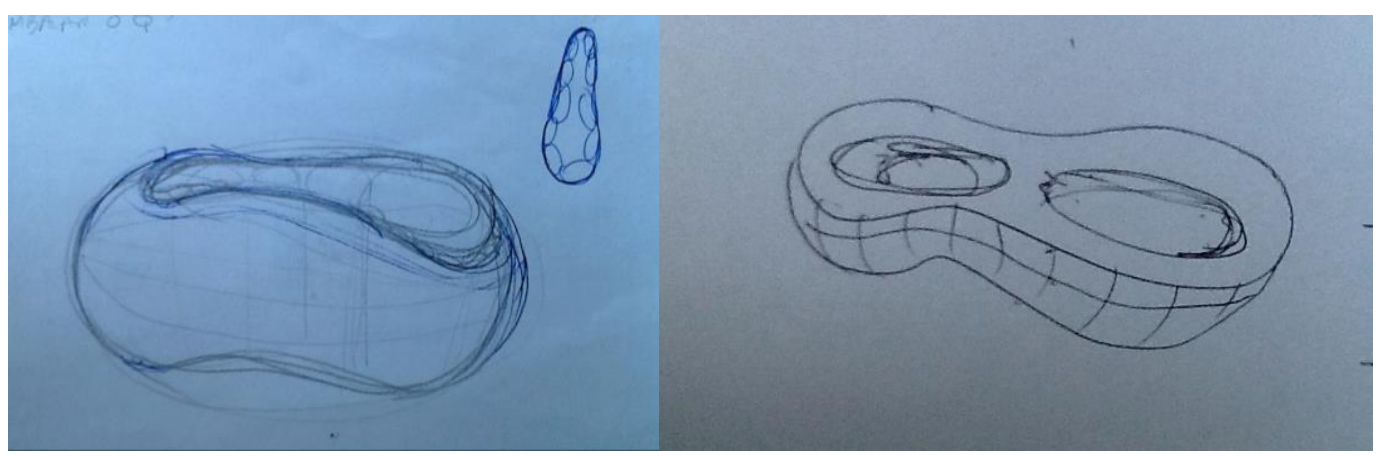

Figura 76 - Desenho à mão livre representando ideia para embalagem, usando analogia com a estrutura alveolar da vagem do amendoim (desenho da autora).

Em seguida, algumas ideias desenhadas acima foram modeladas no software 3D Solidworks. Nas modelagens abaixo nota-se uma semelhança formal com o fruto do amendoim e uma estrutura simplificada e geometrizada dos alvéolos da casca da vagem (Figuras 77, 78 e 79). 


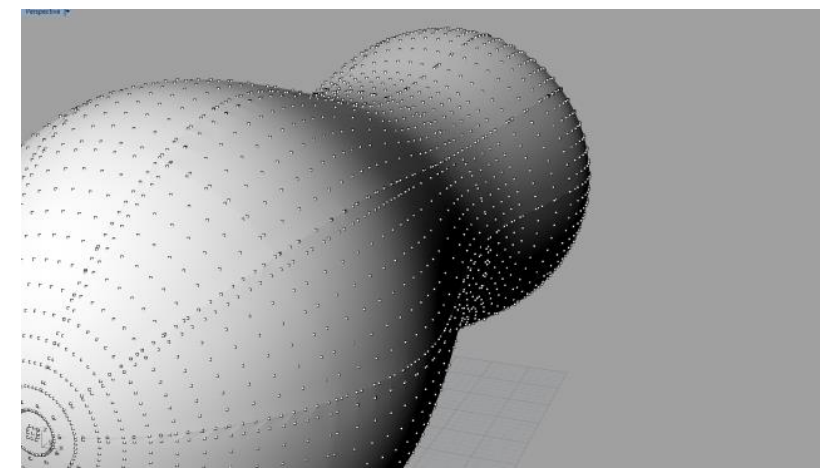

Figura 77 - Modelagem do volume formal no Solidworks.

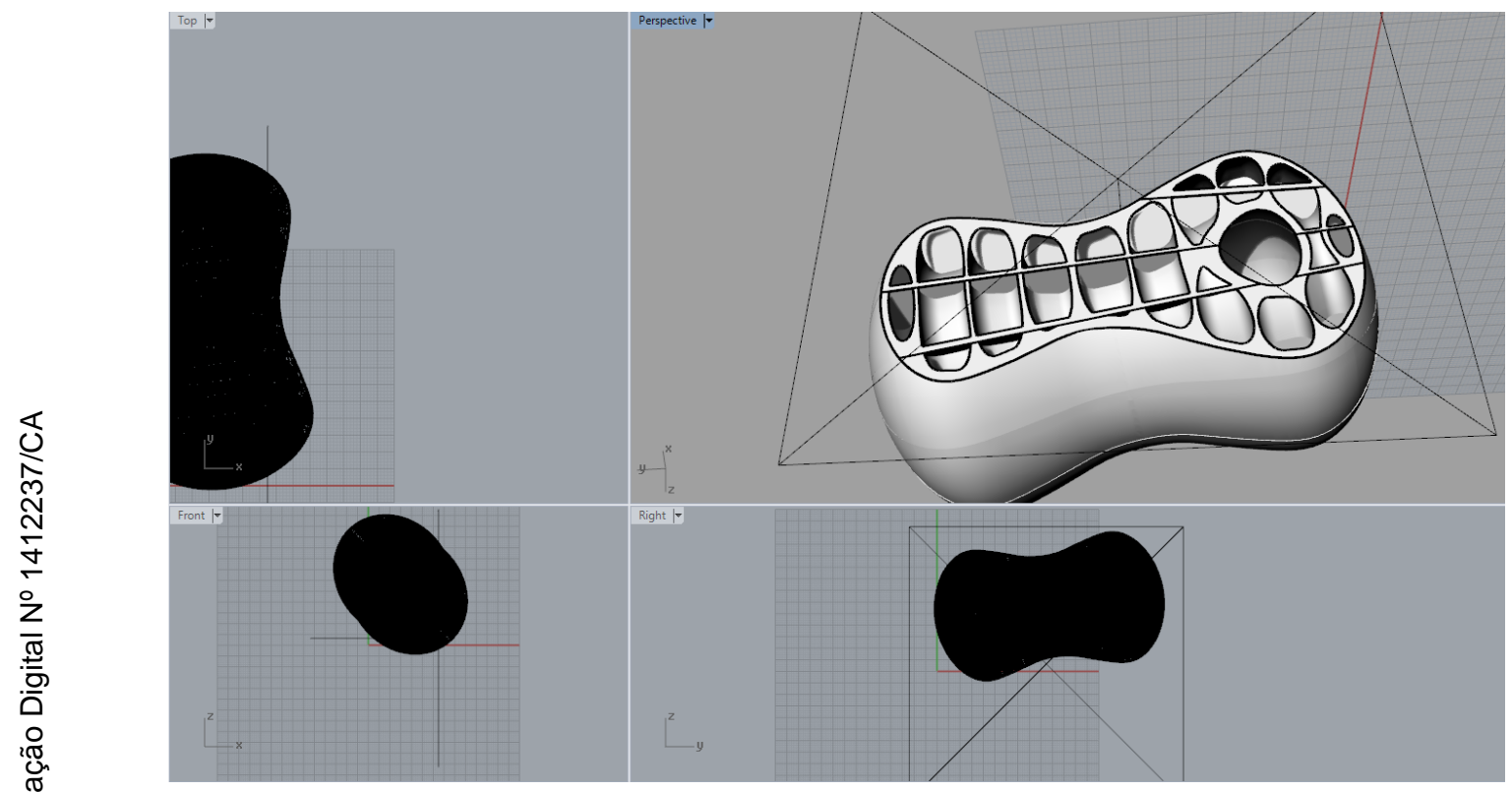

Figura 78 - Corte no volume para visualização das estruturas alveolares projetadas (modelagem de Bruna Paiva e Daniel Nasajon no Solidworks).

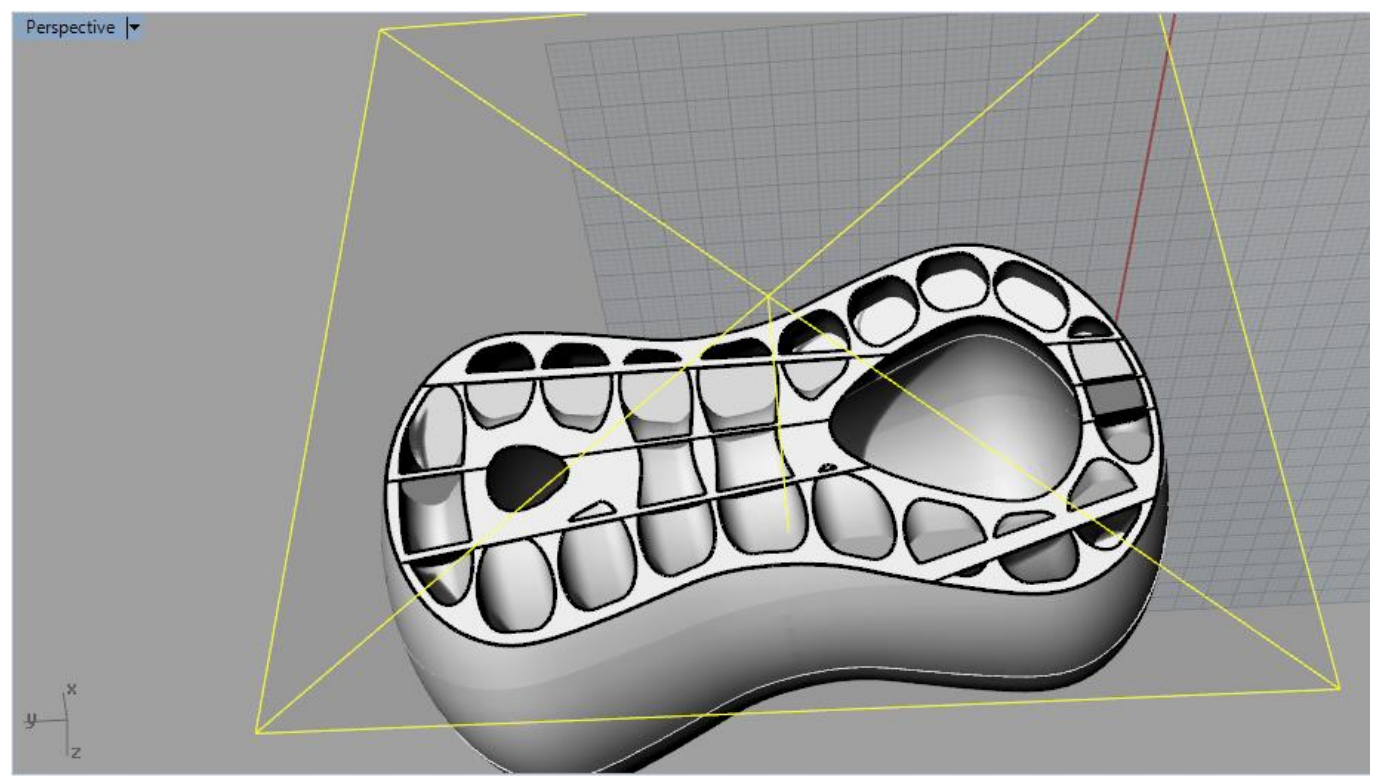

Figura 79 - Detalhe do corte no volume, para visualização das estruturas alveolares projetadas (modelagem de Bruna Paiva e Daniel Nasajon no Solidworks). 
A fim de permitir uma maior liberdade de criação a partir dos volumes formais apresentados acima, modelou-se uma estrutura paramétrica no Solidworks (Figura 81).

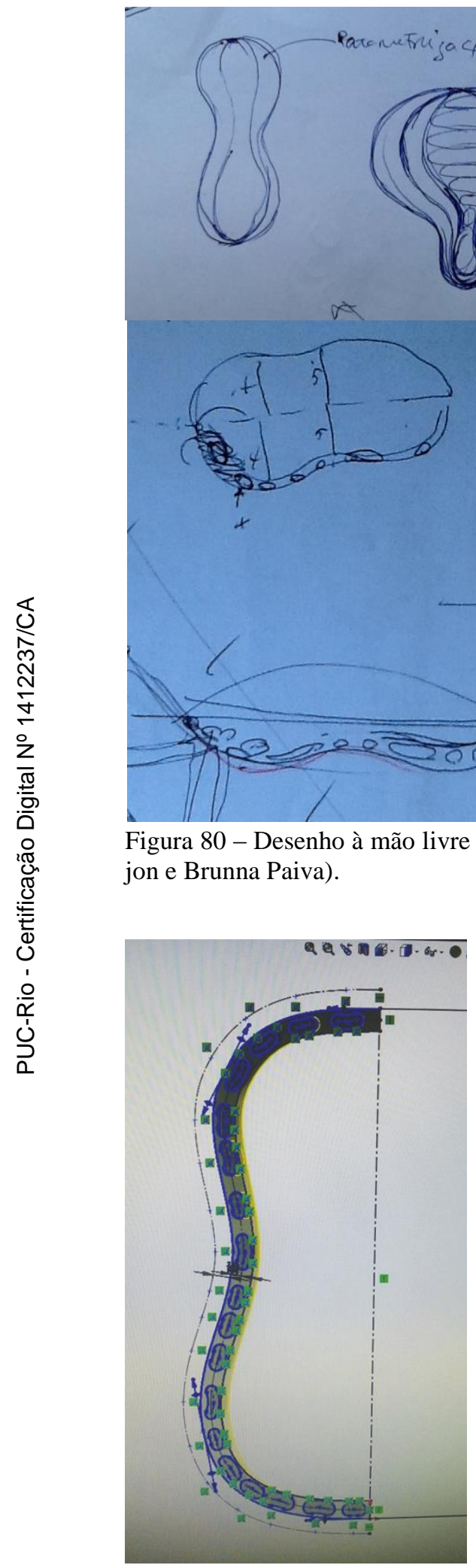

Figura 81 - Desenho de programação paramétrica em Solidworks (desenhos de Daniel Nasajon e Brunna Paiva). 
A parametrização propiciou rapidez e diversidade na exploração formal (a partir da mudança de parâmetros), incluindo o formato dos alvéolos, como podese verificar nos desenhos abaixo.
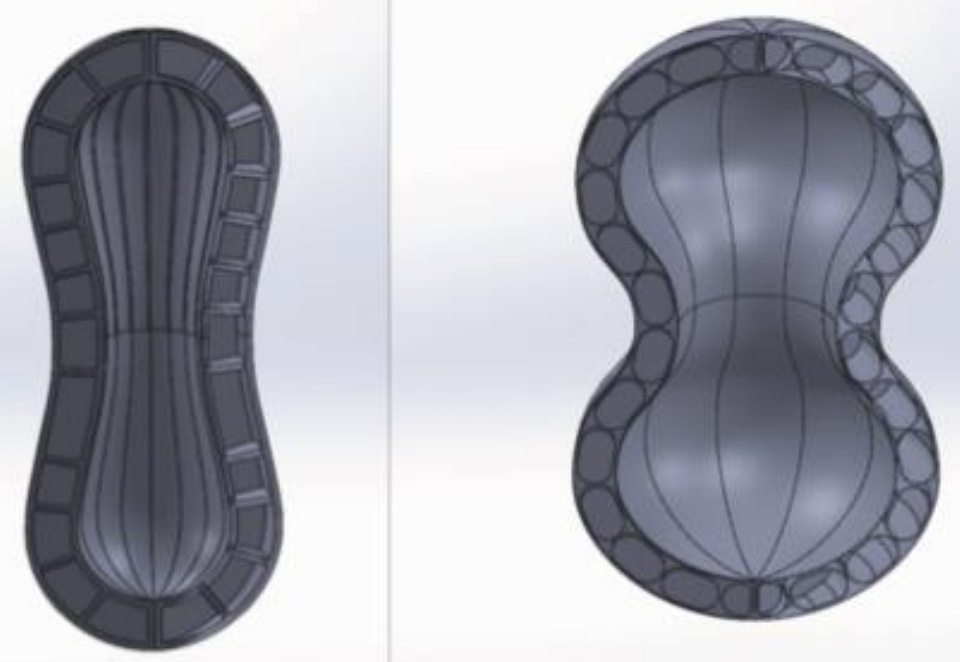

Figura 82 - Desenvolvimento de diferentes formatos de alvéolo. (Modelado no Solidworks por Brunna Paiva e Daniel Nasajon).

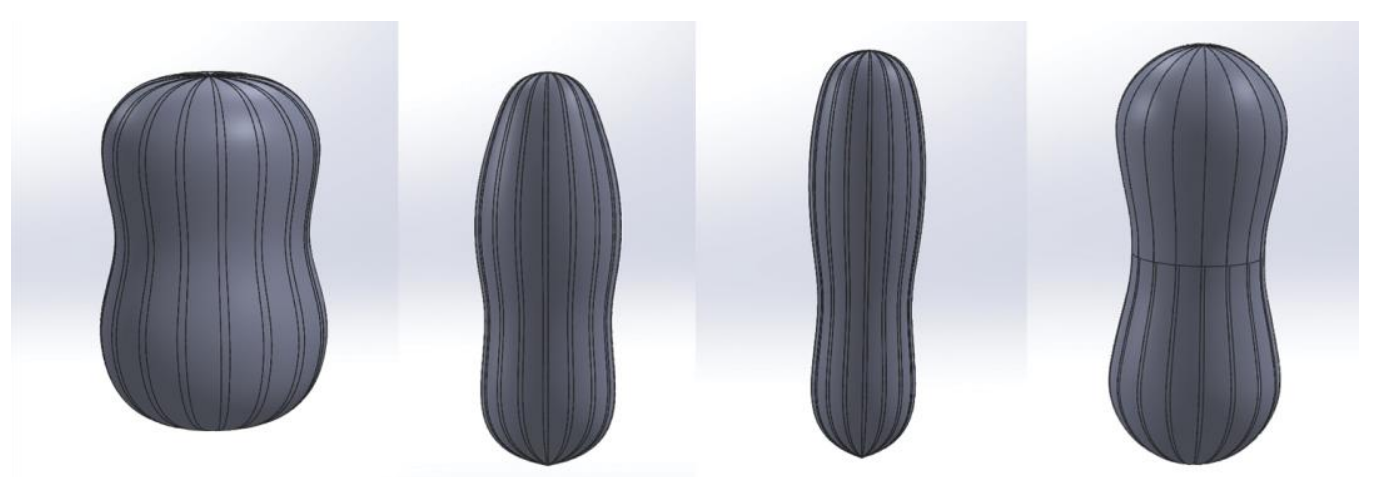

Figura 83 - Formas rapidamente geradas com a programação paramétrica em Solidworks (desenhos de Daniel Nasajon e Brunna Paiva).

Além da exploração formal e estrutural, geraram-se ideias para criação de uma linha de quebra localizada no centro da embalagem, fazendo a transferência do princípio da linha de "soldagem" observada na vagem do amendoim. 


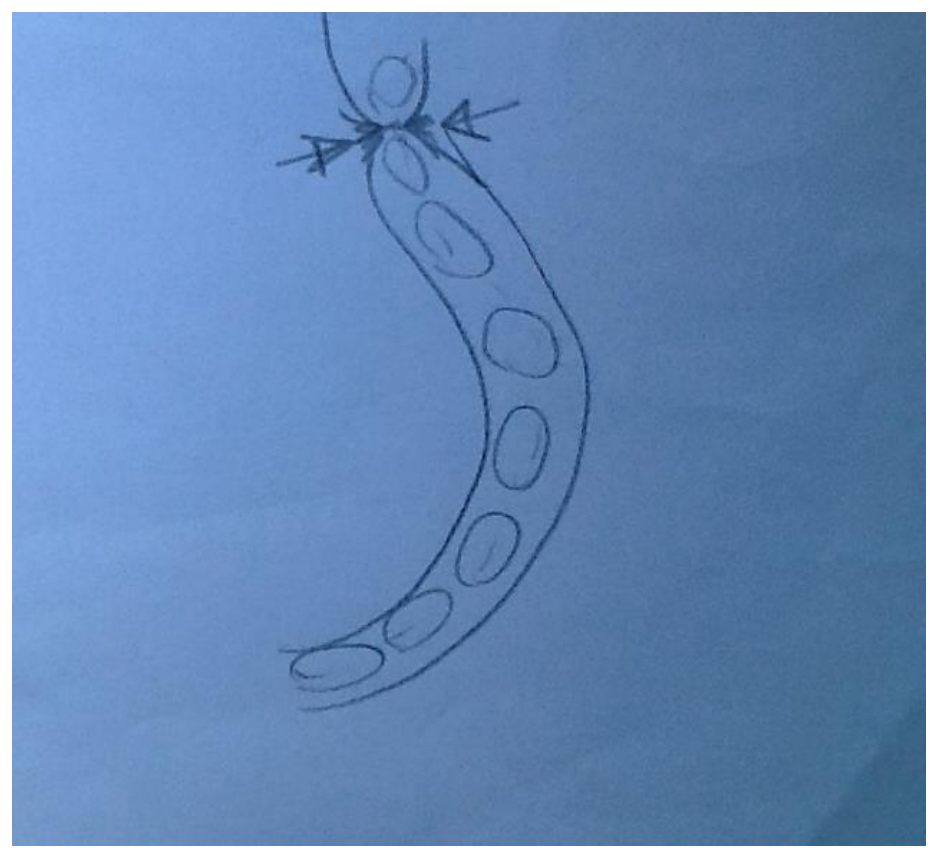

Figura 84 - Desenho à mão livre representando ideia para embalagem, usando analogia com a linha de "soldagem" da vagem do amendoim (desenho da autora).

\subsection{4.}

\section{Etapa B4: Emular conceitos de design do Brainstorm 1}

Essa etapa, baseada na Lente Biomimética para o Design "Biologia para Projetar" (Biomimicry 3.8, 2013), visou aprimorar as melhores ideias do brainstorm a fim de desenvolver conceitos de design. A emulação considera aspectos de forma, configuração, construção, estrutura, escala e padrões. Utilizou-se o software Solidworks e a impressora 3D Felix.

O primeiro conceito de design (a) desenvolvido possuía configuração formal e estrutural muito similar à vagem do amendoim: resistência a quedas e amassamento, pelas camadas de fibras de celulose e material proteico, e proteção com rigidez e leveza, por meio de estruturas alveolares.

$\mathrm{Na}$ emulação sentiu-se necessidade de dimensionar o volume interno para que o mesmo acomodasse algum tipo de alimento que precisasse de proteção elevada, simulando uma embalagem (b). Decidiu-se por embalar dois ovos, pois a fragilidade dos mesmos impõe funções protetivas elevadas para que não quebrem ao longo da cadeia de distribuição. 

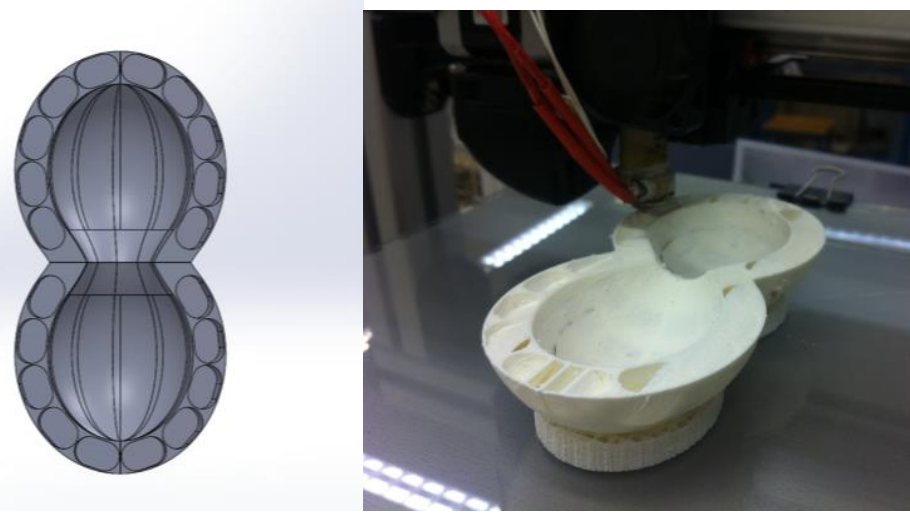

Figura 85 - Modelagem e impressão 3D (Solidworks e Felix-filamento PLA) do conceito (b).

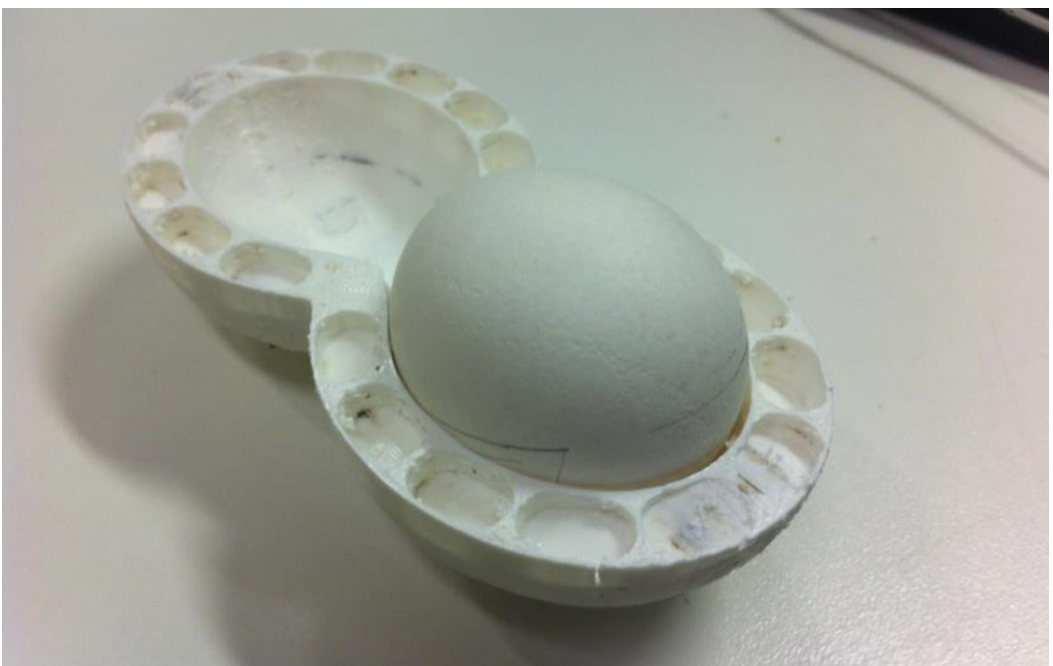

Figura 86 - Um dos lados do protótipo (b) com um ovo (foto da autora).

Um novo conceito de design (c) foi desenvolvido, para que se testasse a estratégia de fragilidade da linha de "soldagem" (aprendida com a vagem do amendoim). Essa linha frágil foi transferida para o design da embalagem de ovos.

A materialização por meio de prototipagem rápida, feita na impressora 3D, permitiu a experimentação da quebra (por esforço manual) na linha de "soldagem" desse conceito (c). Pode-se verificar, nas fotos abaixo, a prototipação e experimentação realizadas. 


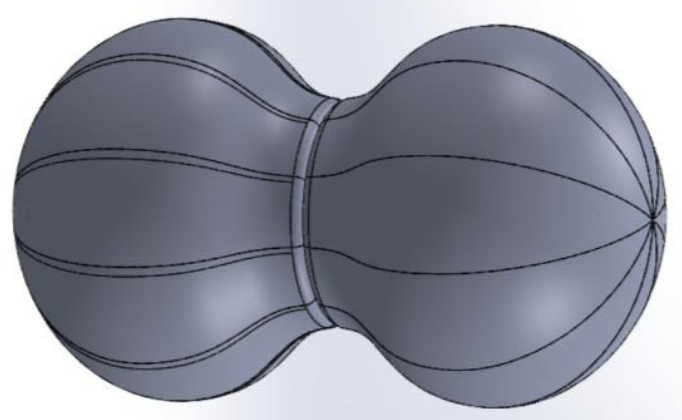

Figura 87 - Modelagem do conceito (c) com linha frágil de "soldagem" no centro da embalagem. (Modelado no Solidworks por Brunna Paiva e Daniel Nasajon).

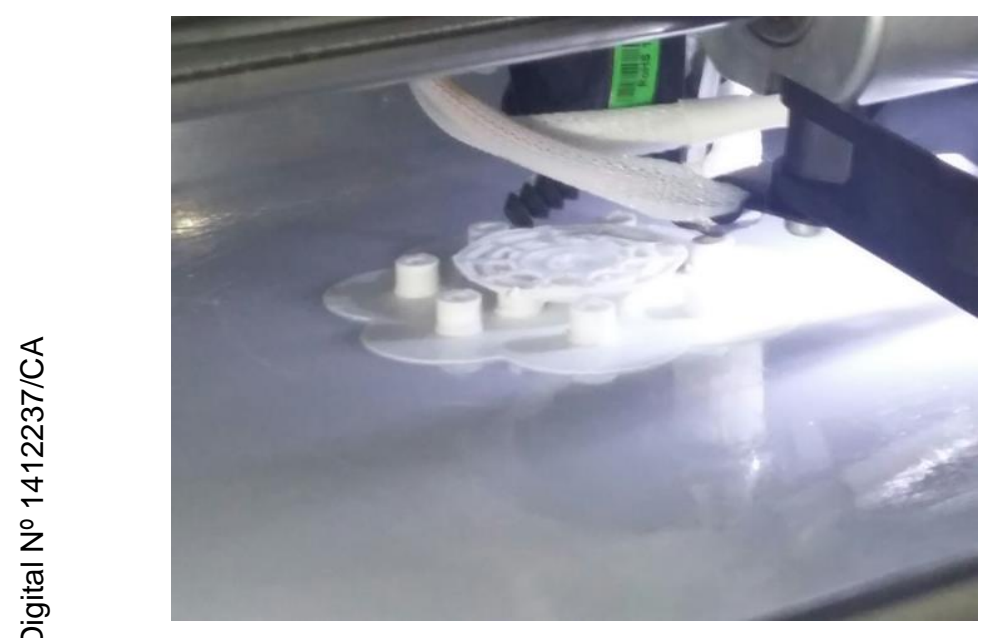

Figura 88 - Protótipo (c) sendo fabricado na impressora 3D Felix com filamento PLA (foto da autora).

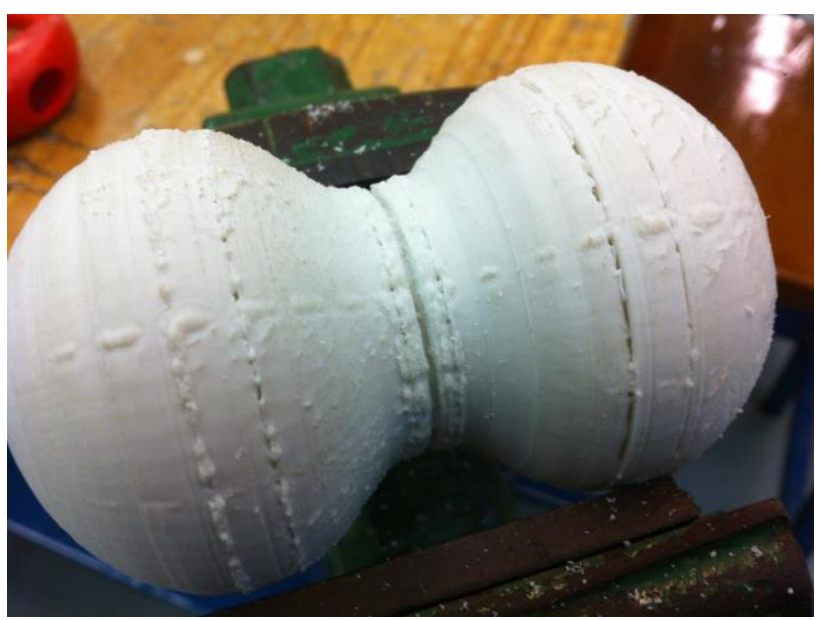

Figura 89 - Protótipo (c) pronto para teste (foto da autora). 


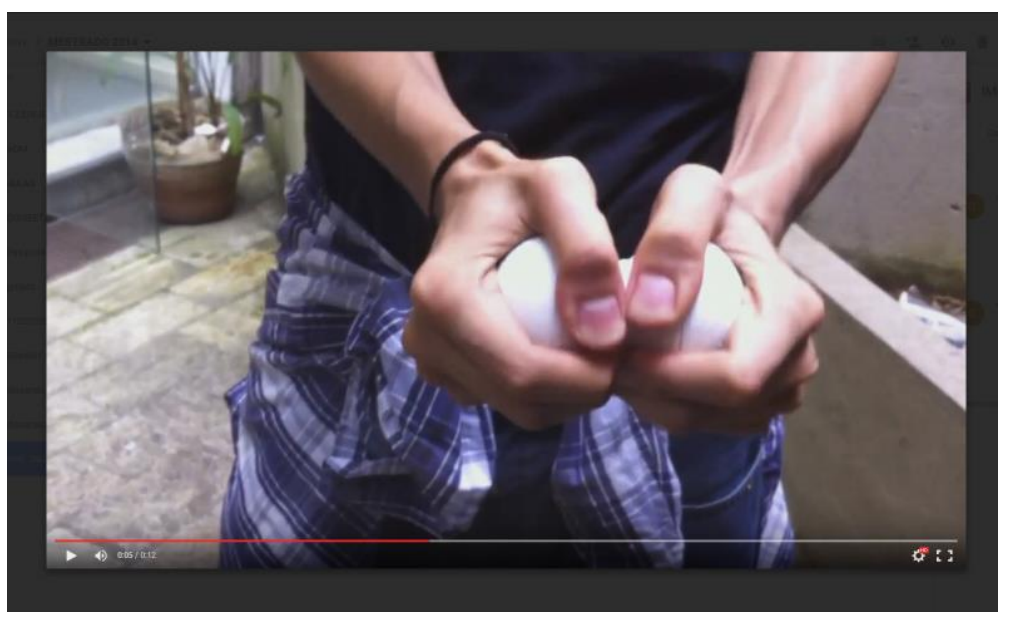

Figura 90 - Frame do vídeo de experimentação da quebra por esforço manual na linha de "soldagem”. Protótipo (c) (foto da autora).

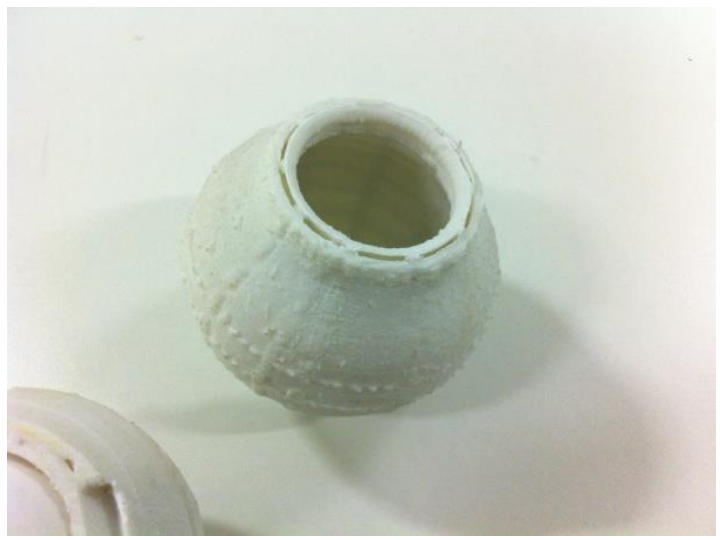

Figura 91 - Protótipo (c) quebrado por esforço manual (foto da autora).

A experiência revelou uma enorme dificuldade de quebra na região da "soldagem", sendo necessário muito esforço para separar as partes, provavelmente devido à dureza do material (PLA), e da espessura da linha de "soldagem".

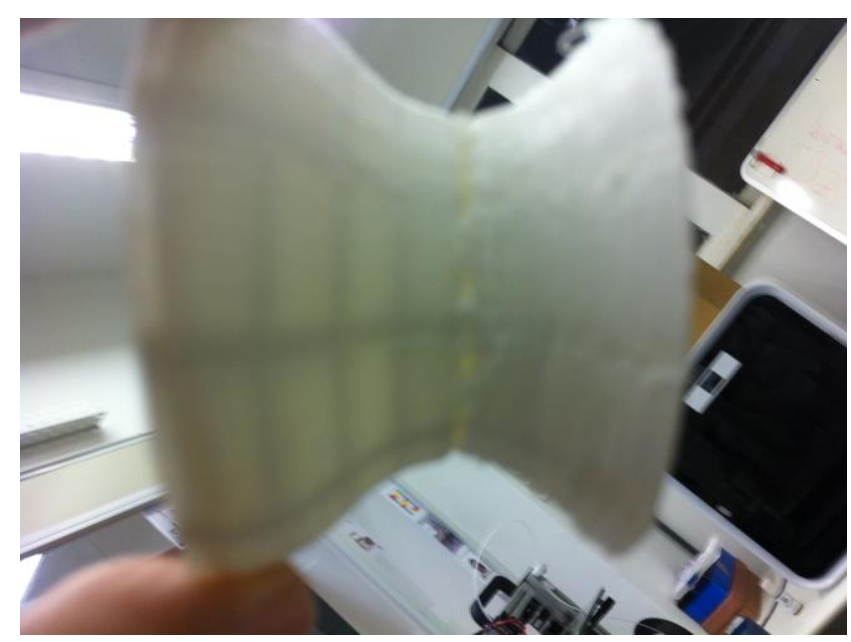

Figura 92 - Detalhe da estrutura alveolar interna e da linha de "soldagem" do protótipo (c) (foto da autora). 
Geraram-se novos conceitos (d) eliminando a parede externa da volumetria, buscando mais leveza e beleza. Sketches foram gerados e novos protótipos impressos.

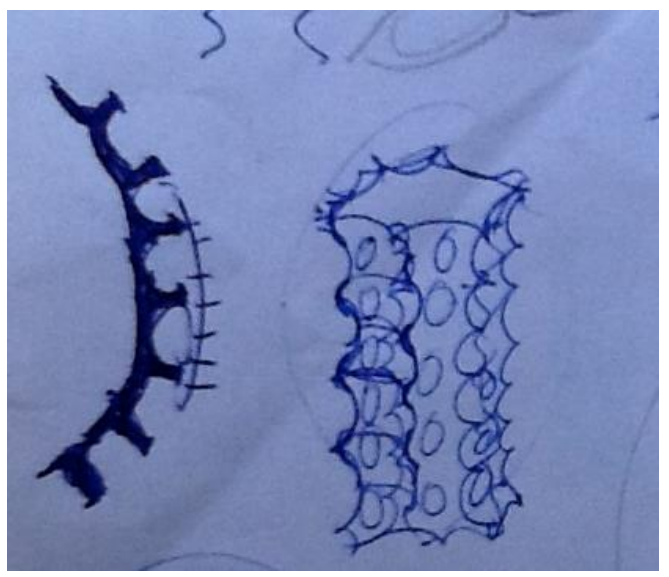

Figura 93 - Sketches com a ideia de eliminação da parede externa (desenhos da autora).

Primeiramente retirou-se a parede externa dos protótipos com a ajuda de uma microretífica. Foram retiradas as paredes externas em um protótipo experimental em escala reduzida como se vê nas fotos abaixo.

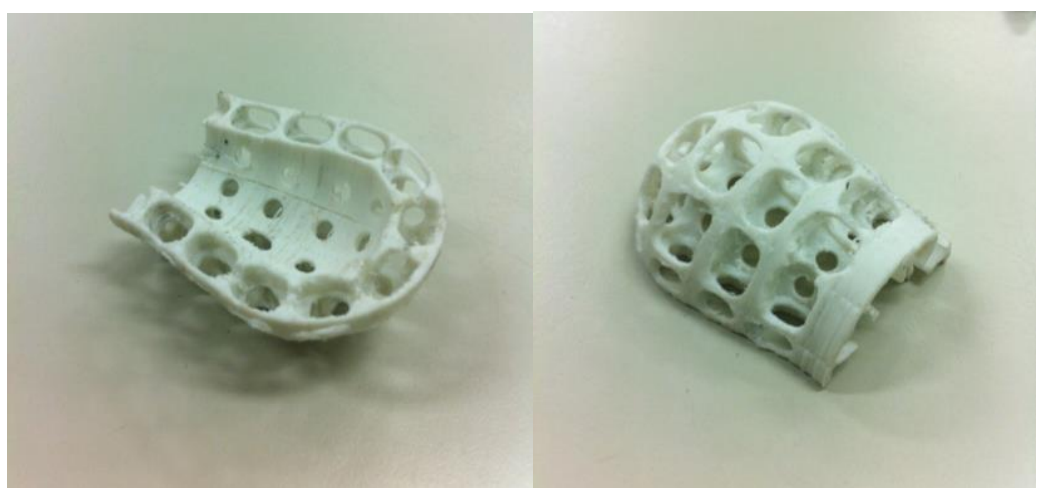

Figura 94 - Protótipos sem as paredes externa e internas retiradas à mão com micro retífica (fotos da autora).

Também retirou-se as paredes externas do protótipo dimensionado para acomodar dois ovos (b).

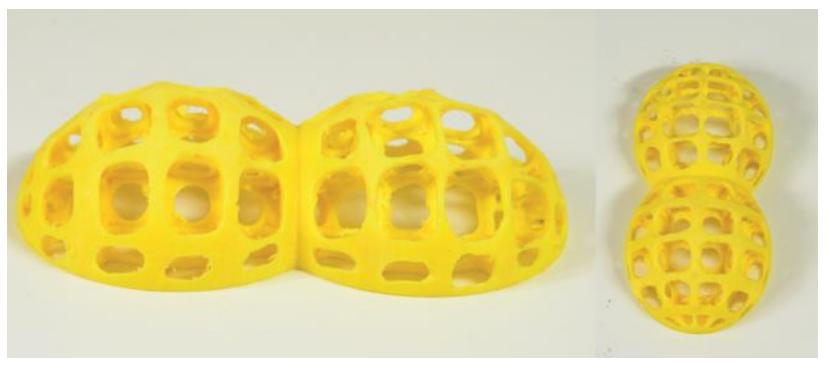

Figura 95 - Protótipo (b) para dois ovos vazado à mão com microretífica. Impresso na Felix com PLA (fotos da autora). 
A fim de garantir maior qualidade formal e de dimensões, modelou-se um novo conceito de design (e), ainda inspirado na estrutura alveolar da casca do amendoim. Para se testar mais rapidamente as funções protetivas desse conceito, modelou-se a embalagem para um único ovo. Note-se abaixo os detalhes da configuração alveolar desse design, modelados no Solidworks.

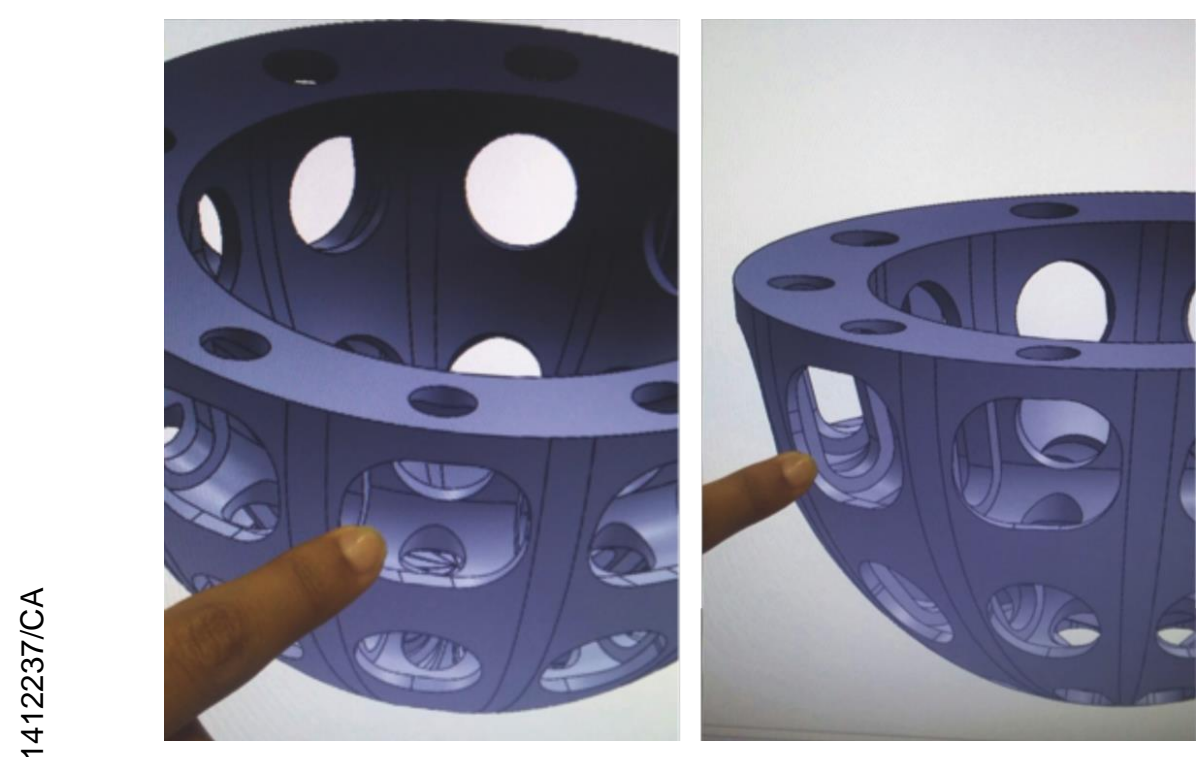

Figura 96- Detalhe do conceito de design (e) sem a parede externa e dimensionado para um ovo. (Modelado no Solidworks por Brunna Paiva).
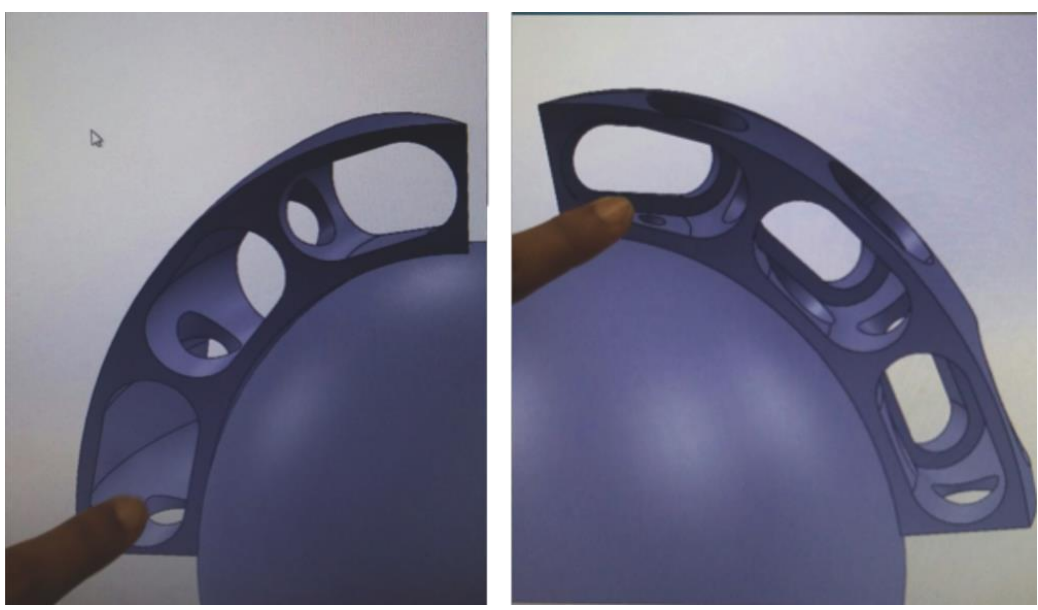

Figura 97 - Detalhe do conceito de design (e) sem a parede externa e dimensionado para um ovo. (Modelado no Solidworks por Brunna Paiva).

Foram executados novos protótipos rápidos na impressora 3D, para realizar testes de queda e impacto e avaliar a proteção aos ovos que esse conceito (e) estava propiciando. 
Nos testes de queda constatou-se que o material usado nos protótipos (filamento PLA), por ter dureza elevada, não estava fazendo a estrutura da embalagem proteger os ovos absorvendo para si o impacto. Ao contrário, estava transferindo todo impacto diretamente para os ovos, fazendo-os quebrar.

Pesquisou-se, portanto, materiais de impressão 3D com menos dureza e descobriu-se os filamentos NinjaFlex (Elastômero Termoplástico) e o SemiFlex (Elastômero Termoplástico com menor maciez). Protótipos rápidos do design (e) foram executados, utilizando-se a impressora 3D Makerbot, e diferentes filamentos/materiais. A experimentação com novos filamentos flexíveis e macios foi crucial para que esse conceito (e) absorvesse impacto, e desta forma protegesse melhor o ovo.

A sequência de fotos abaixo apresenta os protótipos rápidos (e) executados com diferentes filamentos de maior e menor maciez.

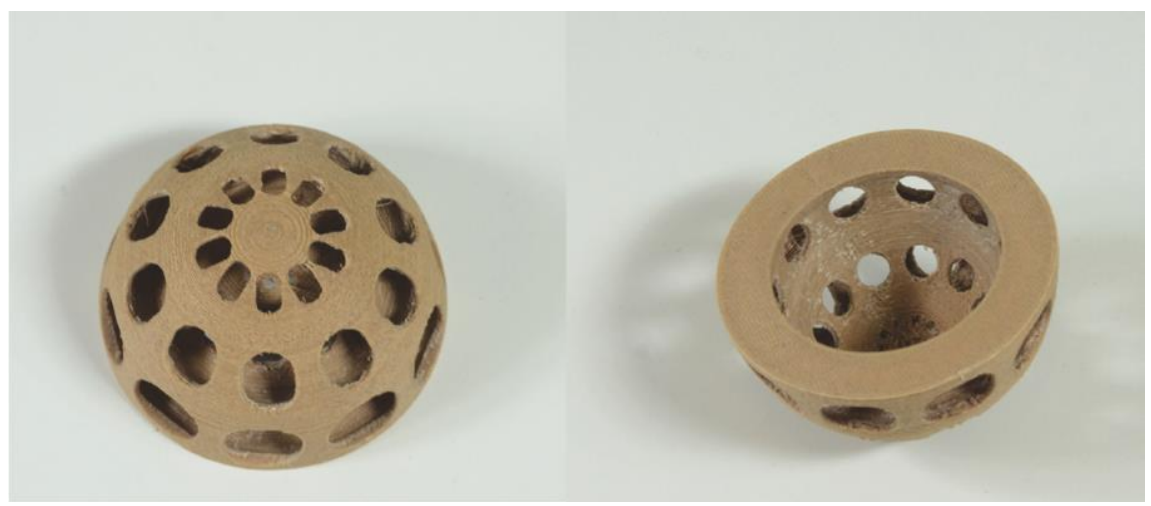

Figura 98 - Protótipo (e1) executado na Makerbot com filamento de pó de madeira (fotos Brunna Paiva).

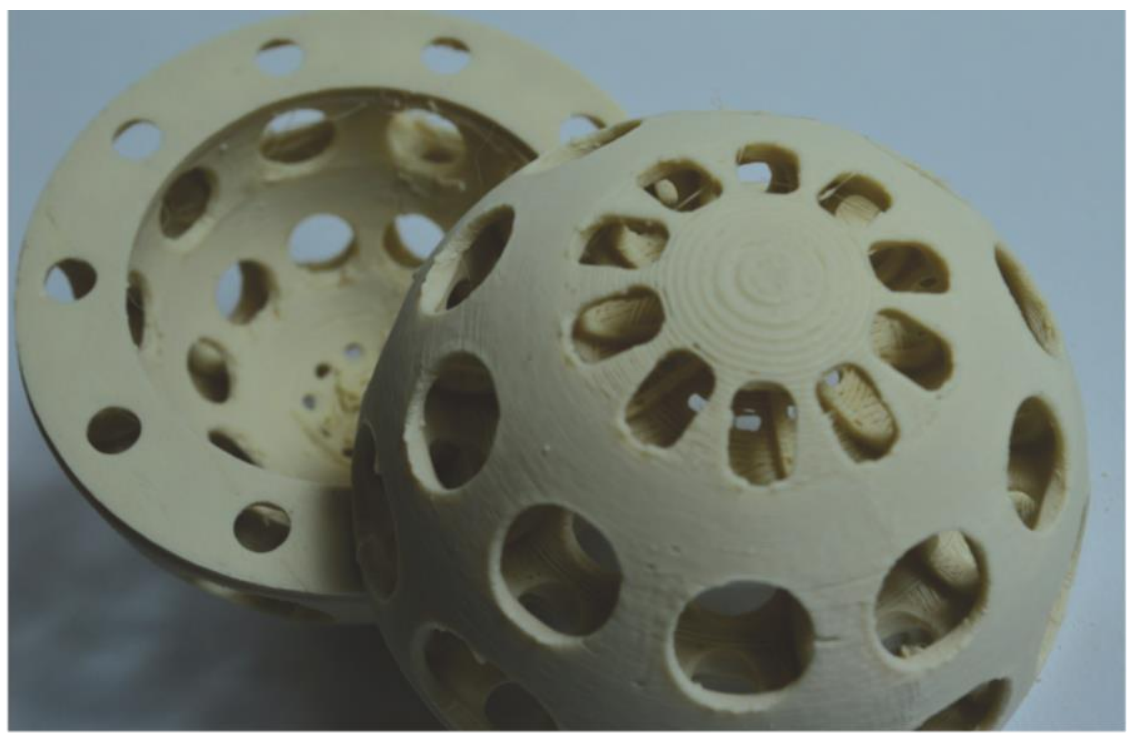

Figura 99 - Protótipo (e2) executado na Makerbot com filamento SemiFlex (foto Brunna Paiva). 


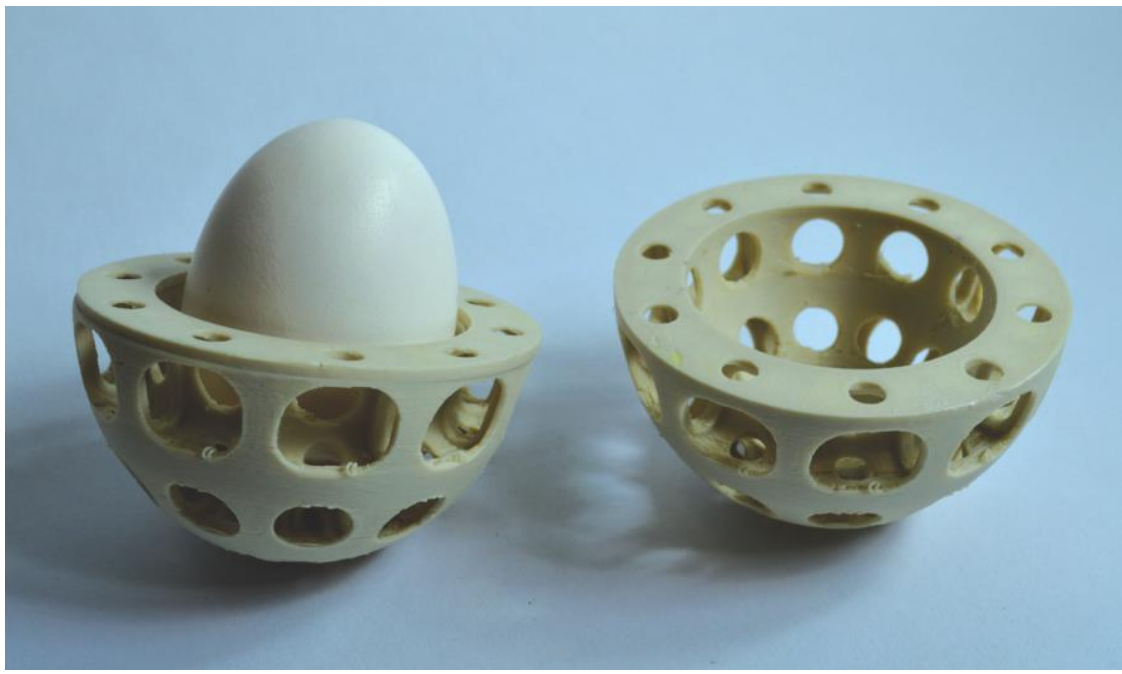

Figura 100 - Protótipo (e2) sendo testado com um ovo (fotos Brunna Paiva).

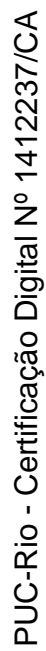

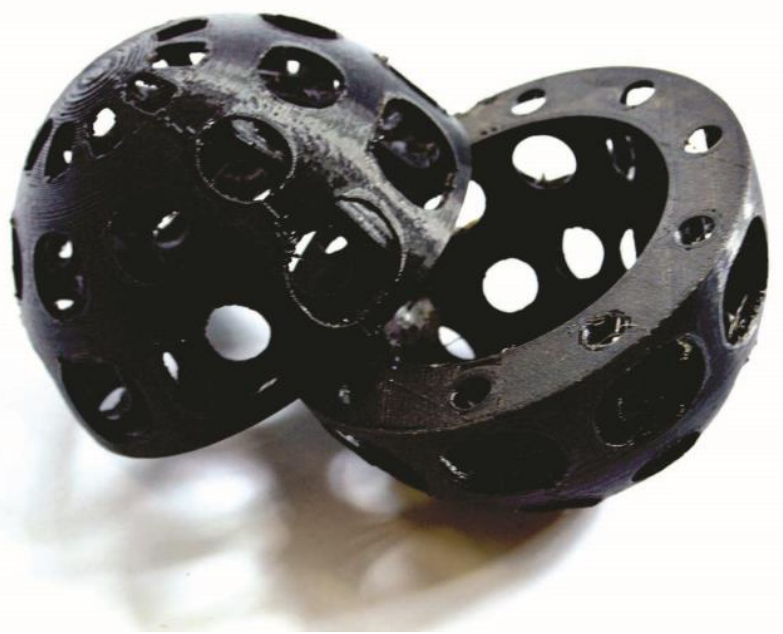

Figura 101 - Protótipo (e3) executado na Makerbot com filamento NinjaFlex (fotos Brunna Paiva).

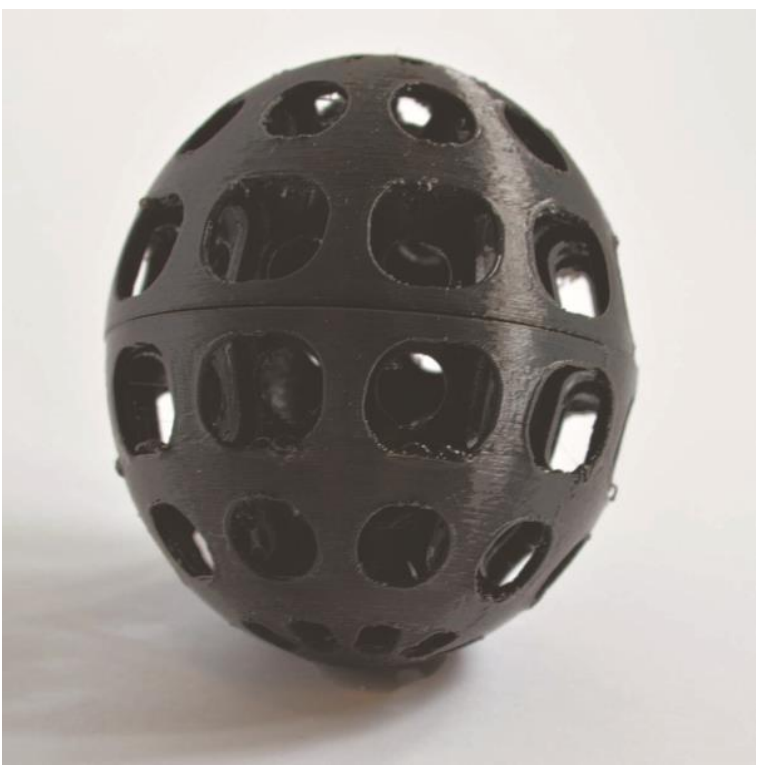

Figura 102 - Protótipo (e3) executado na Makerbot com filamento NinjFlex (fotos Brunna Paiva). 
O protótipo (e3) em NinjaFlex foi selecionados para novos testes de queda. Soltou-se o protótipo (e3) a uma altura de $80 \mathrm{~cm}$ do chão, e o ovo acomodado em seu interior não quebrou. Comprovou-se uma boa resistência desse protótipo à quedas e impactos.

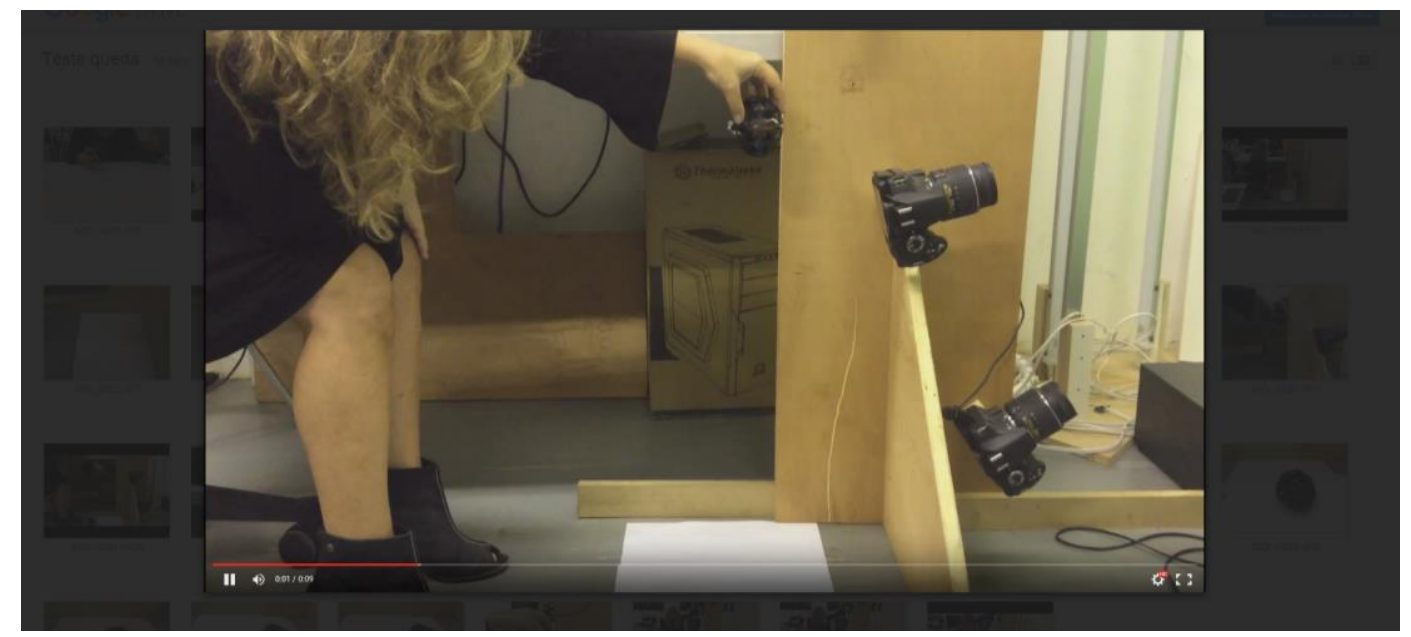

Figura 103 - Frame extraído do vídeo de experimentação com protótipo (e3) de resistência à queda. Momento 1 (fotos Daniel Nasajon).

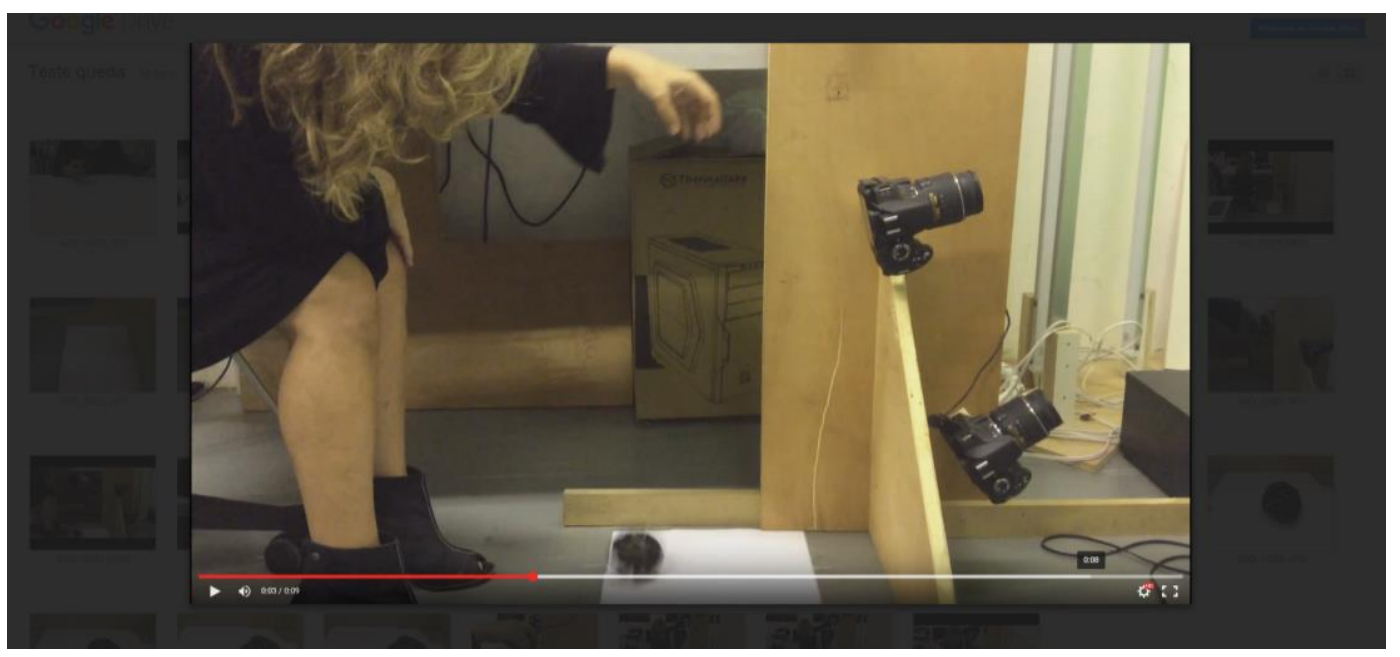

Figura 104 - Frame extraído do vídeo de experimentação com protótipo (e3) de resistência à queda. Momento 2 (fotos Daniel Nasajon).

Após essa experimentação, aperfeiçoou-se mais o conceito de design buscando desalinhar os alvéolos para obter mais resistência à queda. 


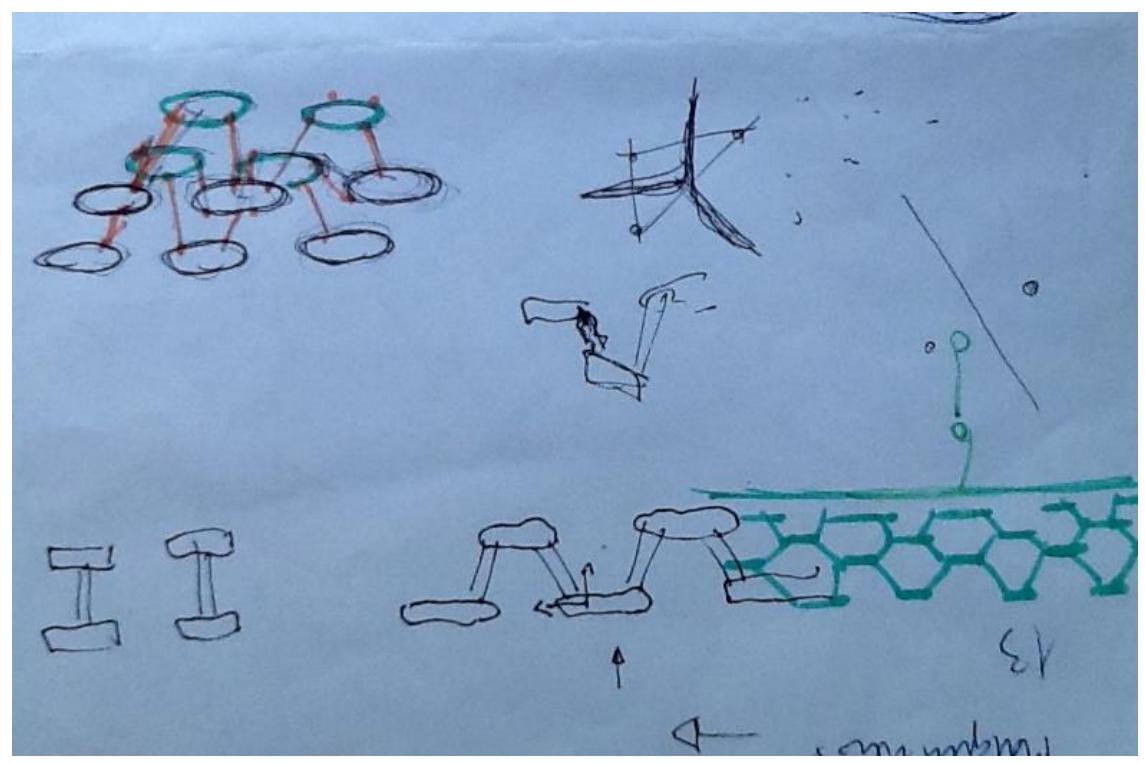

Figura 105 - Desenhos à mão com a ideia de desalinhar os alvéolos (desenhos da autora).

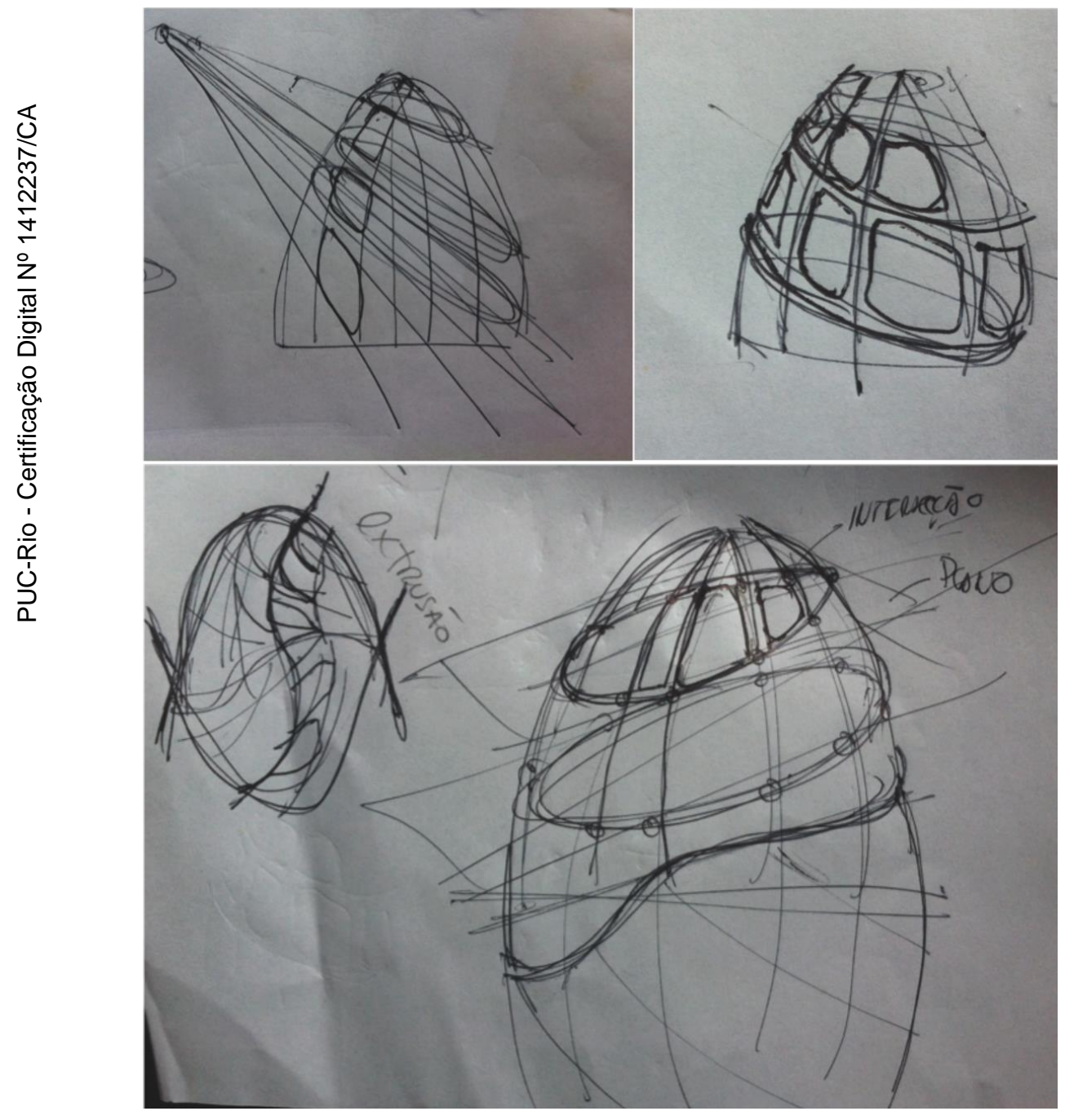

Figura 106 - Desenhos à mão com a ideia de desalinhar os alvéolos (desenhos de Federico Hess). 


\subsection{5.}

\section{Etapa B5: Brainstorm 2 - novas ideias bioinspiradas}

Outras sessões criativas foram realizadas e novas ideias geradas para o desenvolvimento de novos conceitos de design. Seguiu-se com a mesma metodologia, focando em explorar analogias com alvéolos observados na vagem do amendoim para posterior transferência desse princípio para o design de embalagem.

Nas sequências de desenhos abaixo, são representadas algumas dessas analogias e transferências.
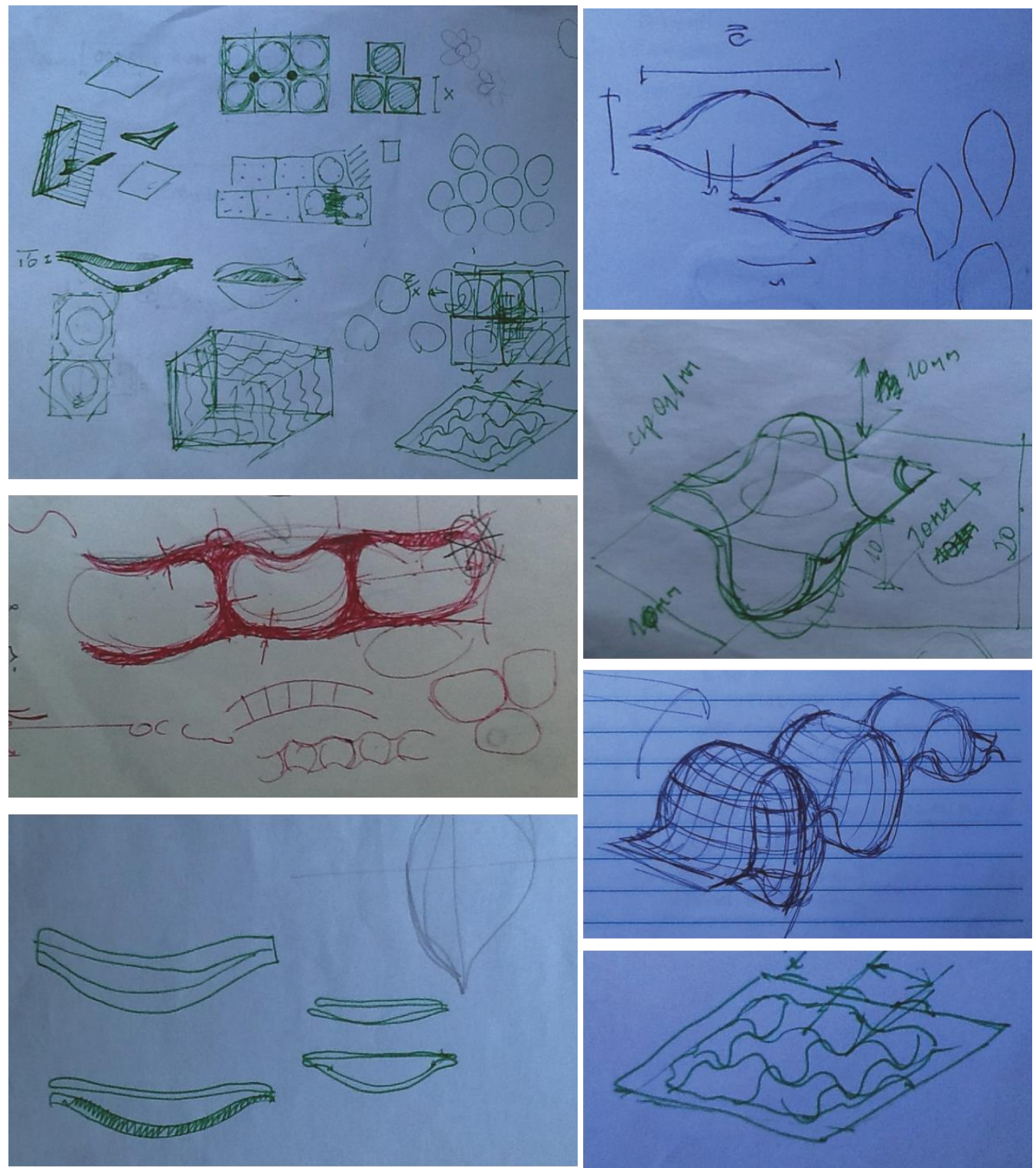

Figura 107 - Desenhos à mão explorando analogias com alvéolos da vagem do amendoim (desenhos da autora). 

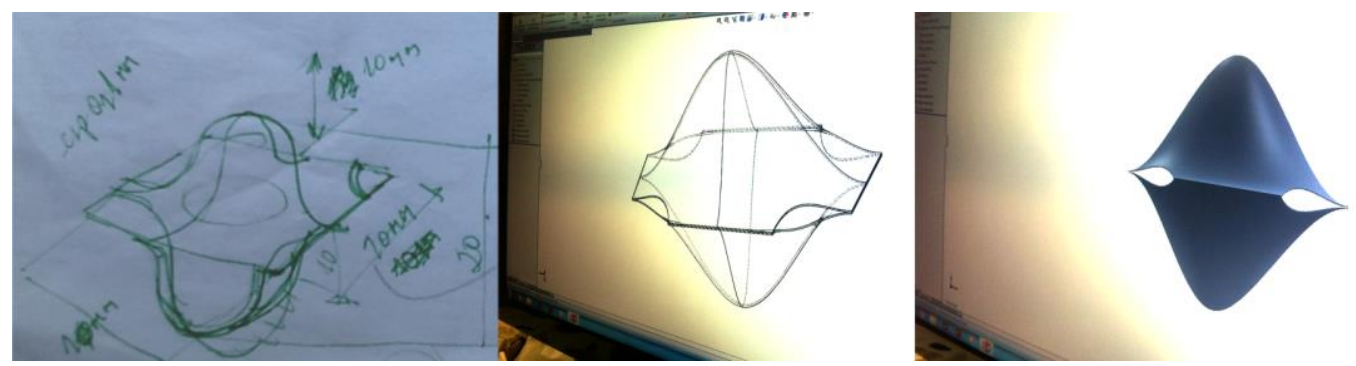

Figura 108 - Sequência de desenhos explorando configurações de alvéolos (desenhos da autora).

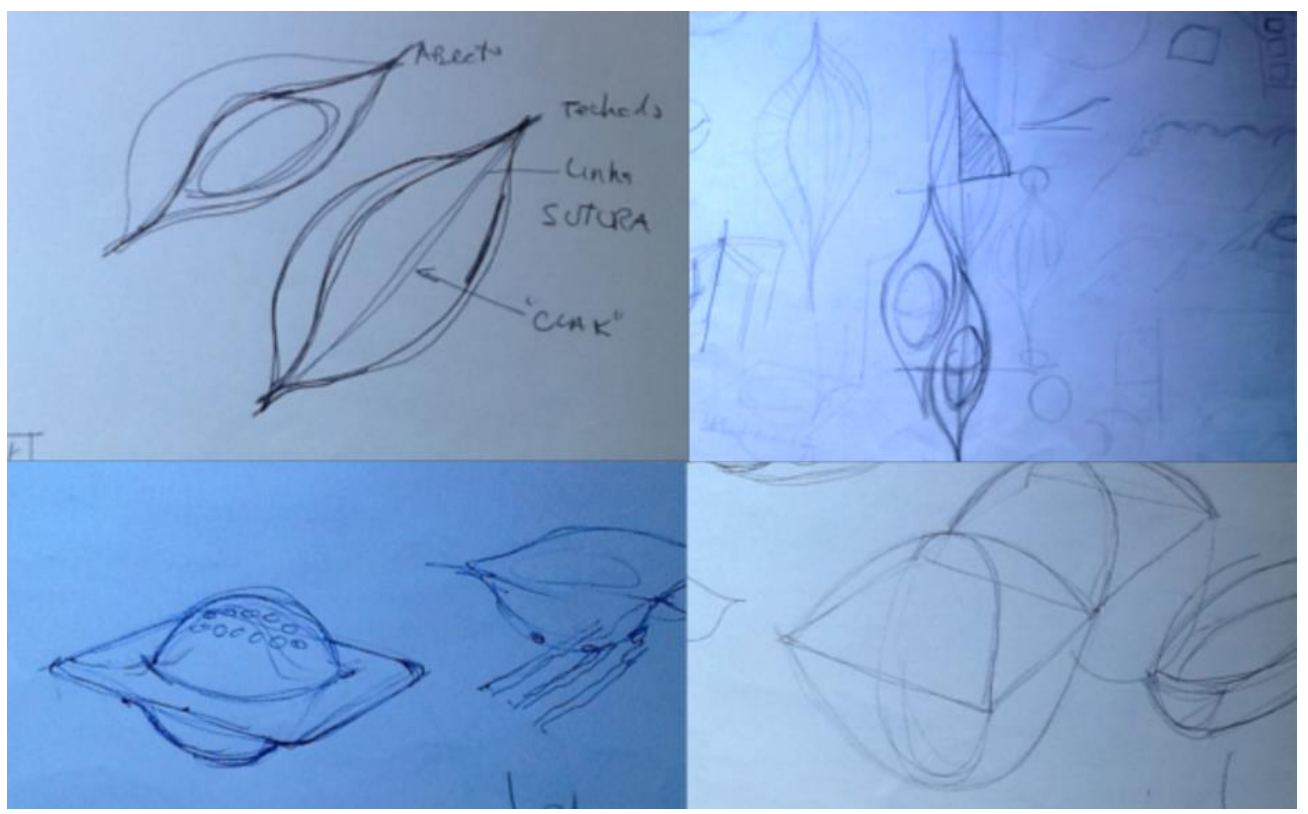

Figura 109 - Desenhos à mão explorando configurações de alvéolos (desenhos da autora).

\subsection{6.}

\section{Etapa B6: Emular conceitos de design do Brainstorm 2}

As melhores ideias do brainstorm 2 foram selecionadas para aprimoramento. Considerou-se, portanto, aspectos de forma, configuração, construção, estrutura, escala e padrões para que as ideias evoluíssem para novos conceitos de design biomimético. Nessa etapa utilizou-se o software Solidworks e a impressora 3D Felix e Makerbot, usando filamentos PLA e NinjaFlex.

Abaixo foto da impressora iniciando a prototipação e o resultado impresso do conceito (f). 


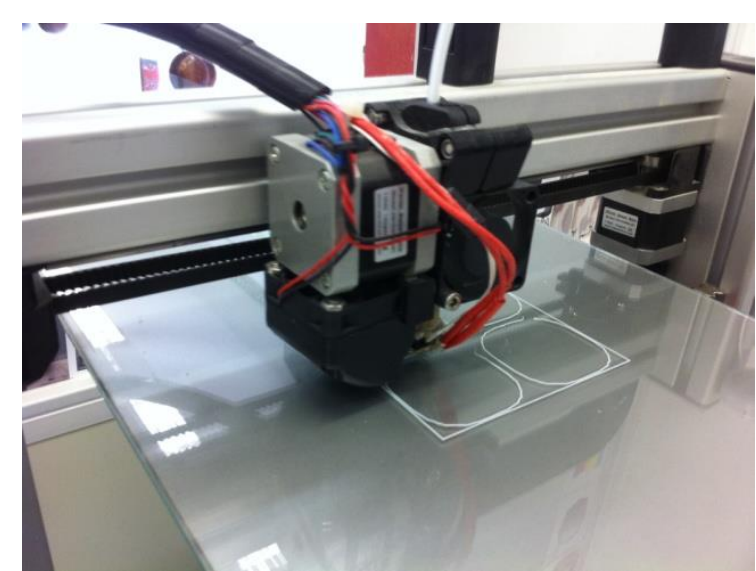

Figura 110- Impressora Felix iniciando protótipo (f) (fotos da autora no NEXT).
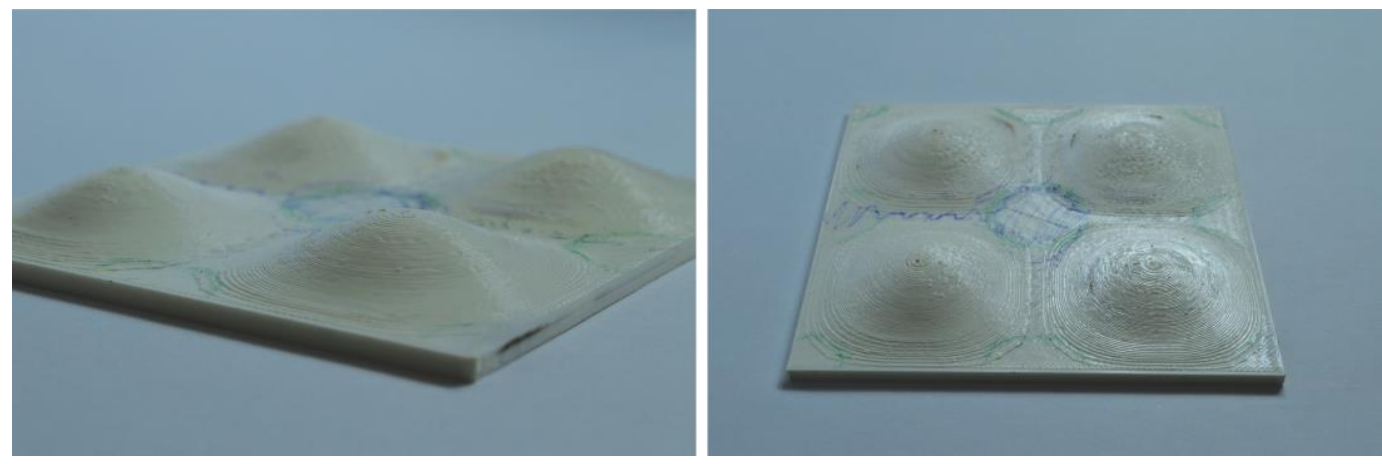

Figura 111 - Protótipo (f) impresso na Felix com filamento PLA (fotos da autora).

Aprimorou-se a modelagem do alvéolo e repetiu-se essa unidade lado a lado, formando uma espécie de placa alveolar. Abaixo, o resultado dessa modelagem (conceito g).

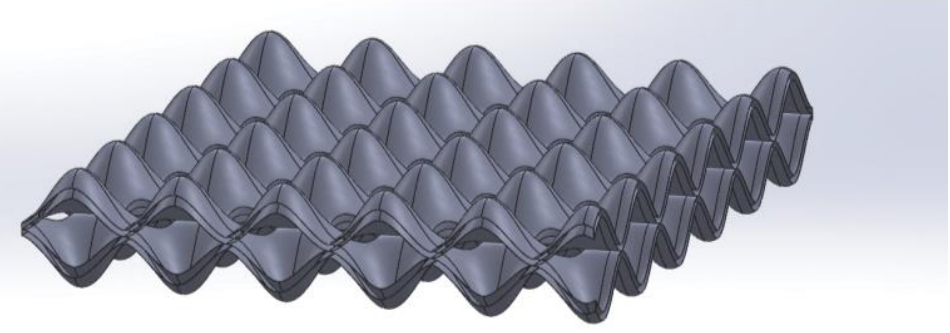

Figura 112 - Modelagem do conceito (g) - placa alveolar (modelagem 3D de Daniel Nasajon). 
Buscou-se uma variação "face simples" da placa, visando economia de material. O desenho técnico desse conceito (h) está apresentado abaixo.

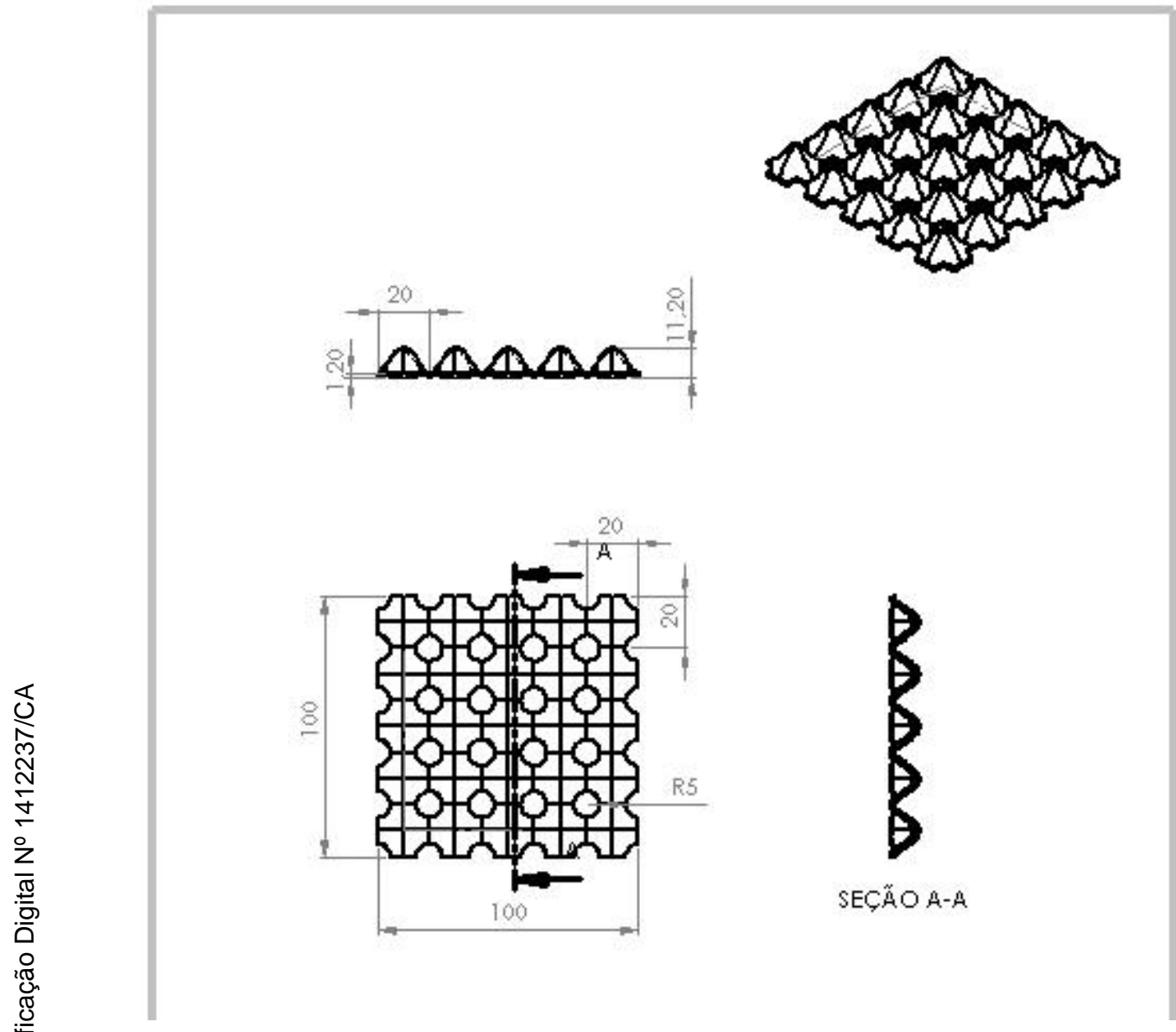

Figura 113 - Desenho técnico do conceito (h) "face simples" e especificações dimensionais gerais da placa.

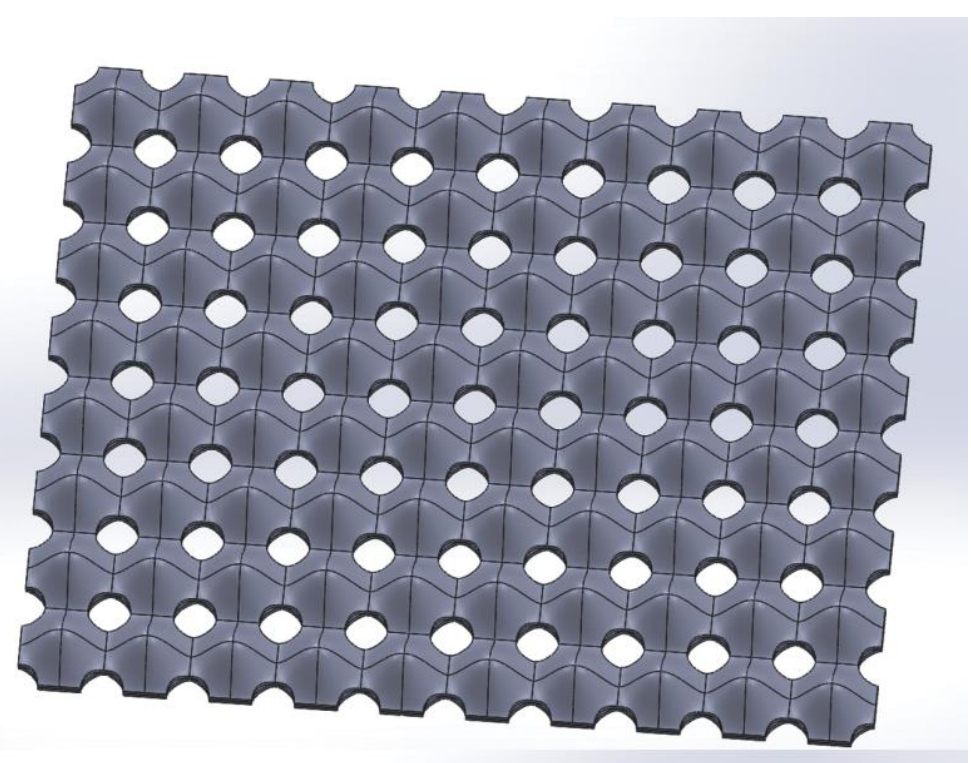

Figura 114 - Modelagem do conceito (h) - placa alveolar "face simples" (modelagem 3D de Daniel Nasajon). 
A materialização da modelagem digital 3D foi executada por meio de prototipagem rápida, feita nas impressoras 3D Makerbot e Felix, com filamento NinjaFlex (Figura 115), e permitiu a experimentação física do conceito (h). O resultado dessa impressão verifica-se abaixo em uma placa "face simples" medindo 10 x 10 cm (conceito h). (Figura 116).

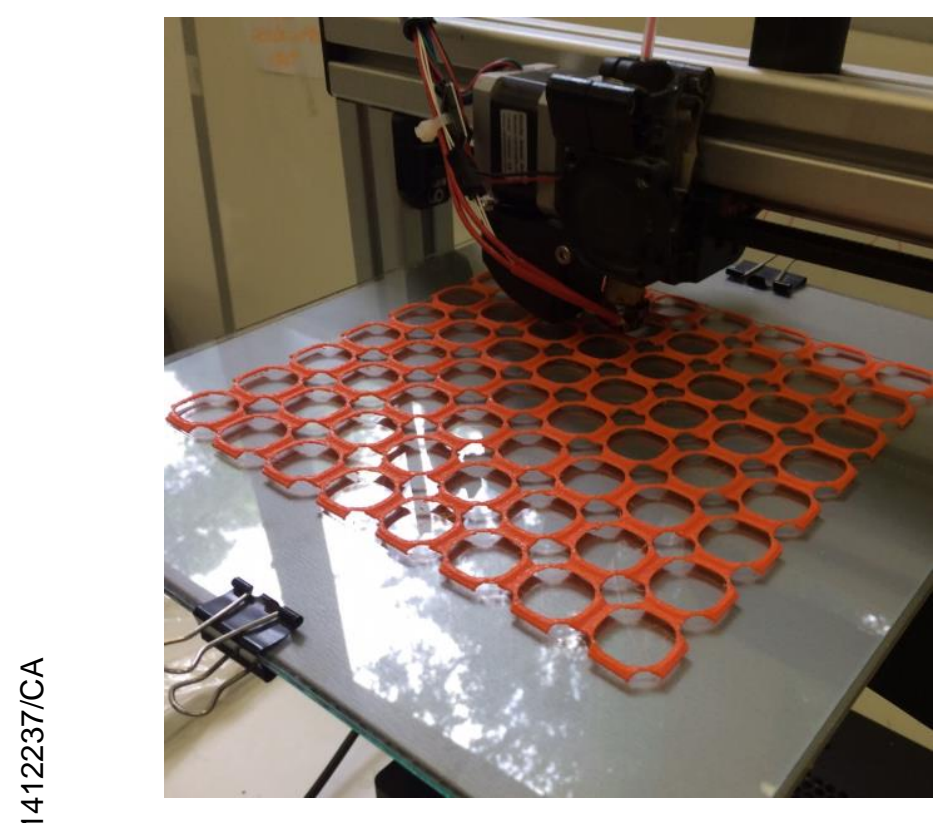

Figura 115 - Impressão 3D do conceito (h) na impressora Felix com NinjaFlex.

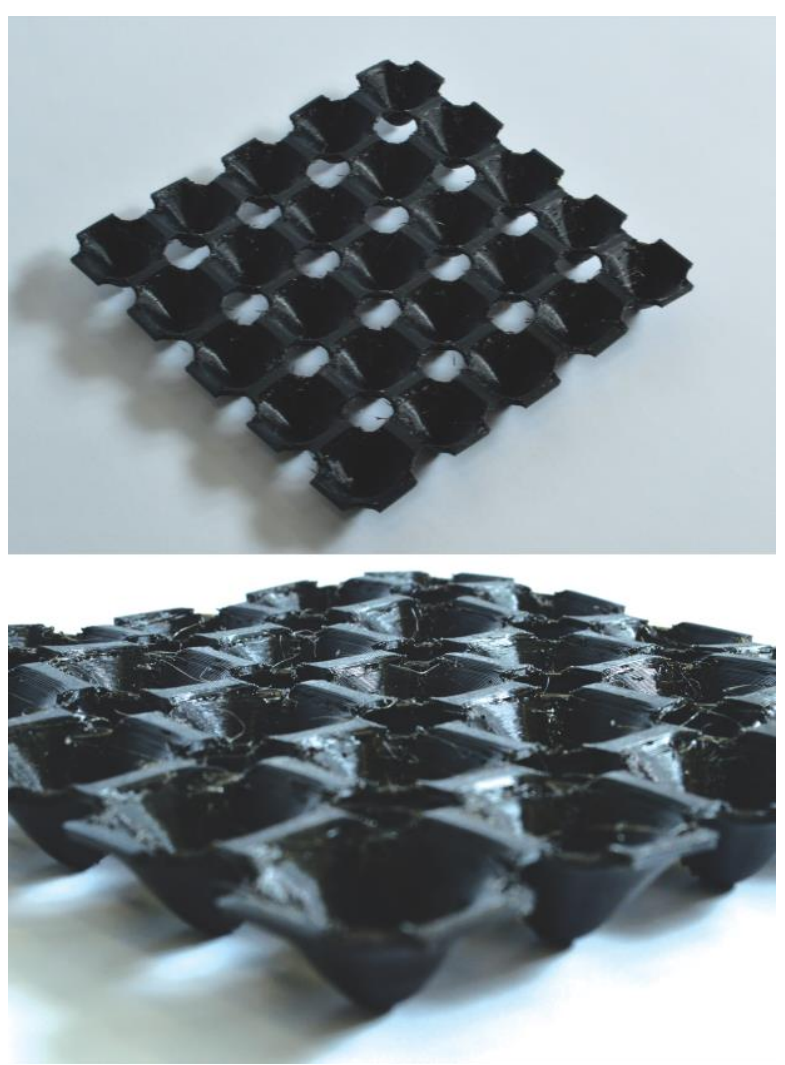

Figura 116 - Protótipo placa "face simples" medindo 10x10 cm. Impresso em 3D (Makerbot com NinjaFlex). 
O material Ninjaflex, macio e flexível (Elastômero Termoplástico), e a estrutura cônica de um dos lados dos alvéolos induziram a uma experiência de empurrar com o dedo um dos cones para baixo (Figura 117). Essa ação foi repetida em outros cones provocando uma deformação na placa, transformando a configuração plana da mesma em uma configuração cilíndrica. Essa experiência com o protótipo do conceito (h) está ilustrada passo-a-passo nas fotos abaixo.
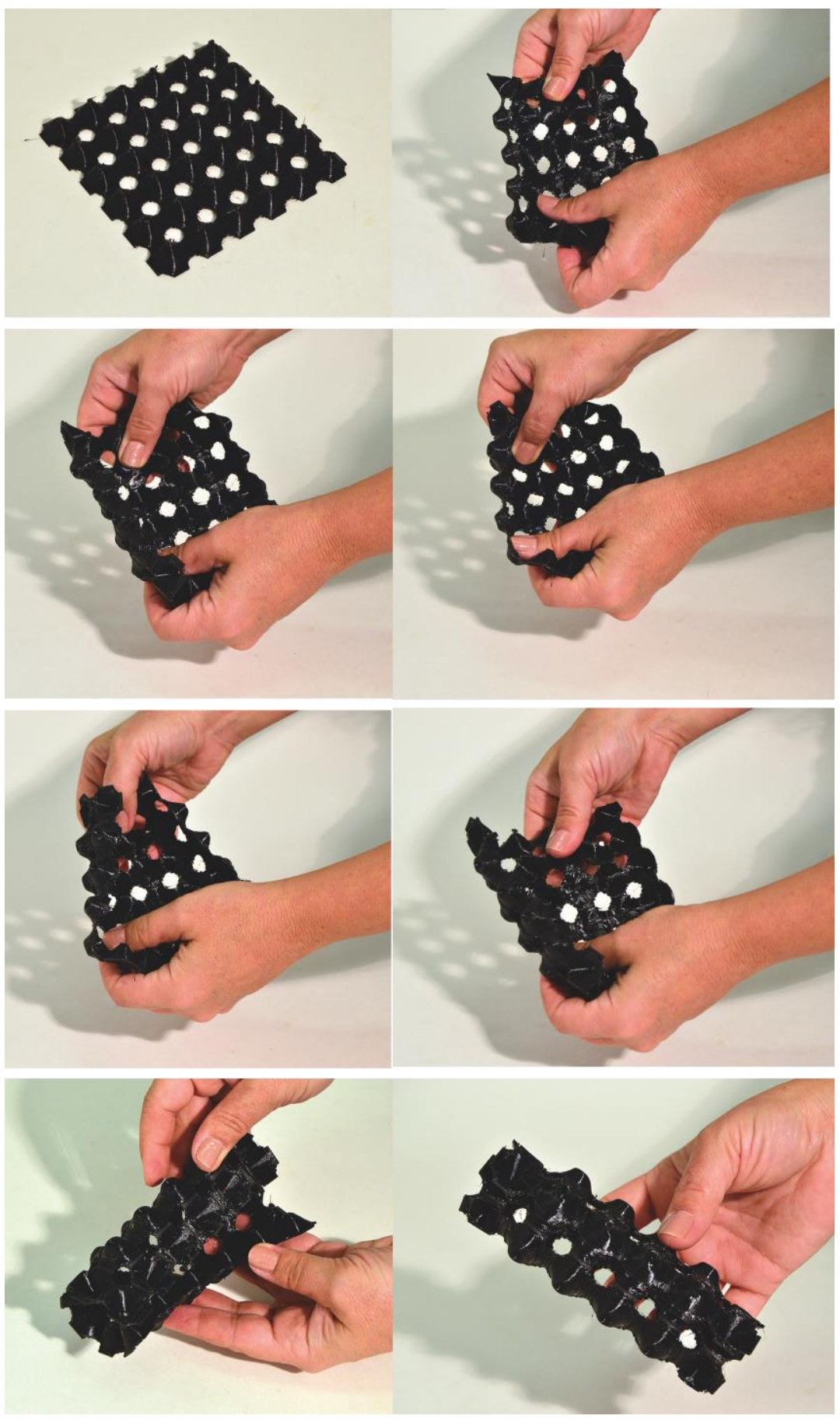

Figura 117 - Protótipo 10x10 cm do conceito (h): placa alveolar face simples, impresso em 3D (Makerbot com NinkaFlex) e o processo de transformação do plano por meio de tensão mecânica. 
Seguiu-se a experimentação com o protótipo do conceito (h), com o objetivo de verificar sua aplicabilidade em embalagem. Para tanto, colocou-se uma pequena quantidade de vagens de amendoim na parte interna da placa (cones empurrados para fora). Verificou-se uma adequada proteção às vagens, como registrado na foto abaixo.

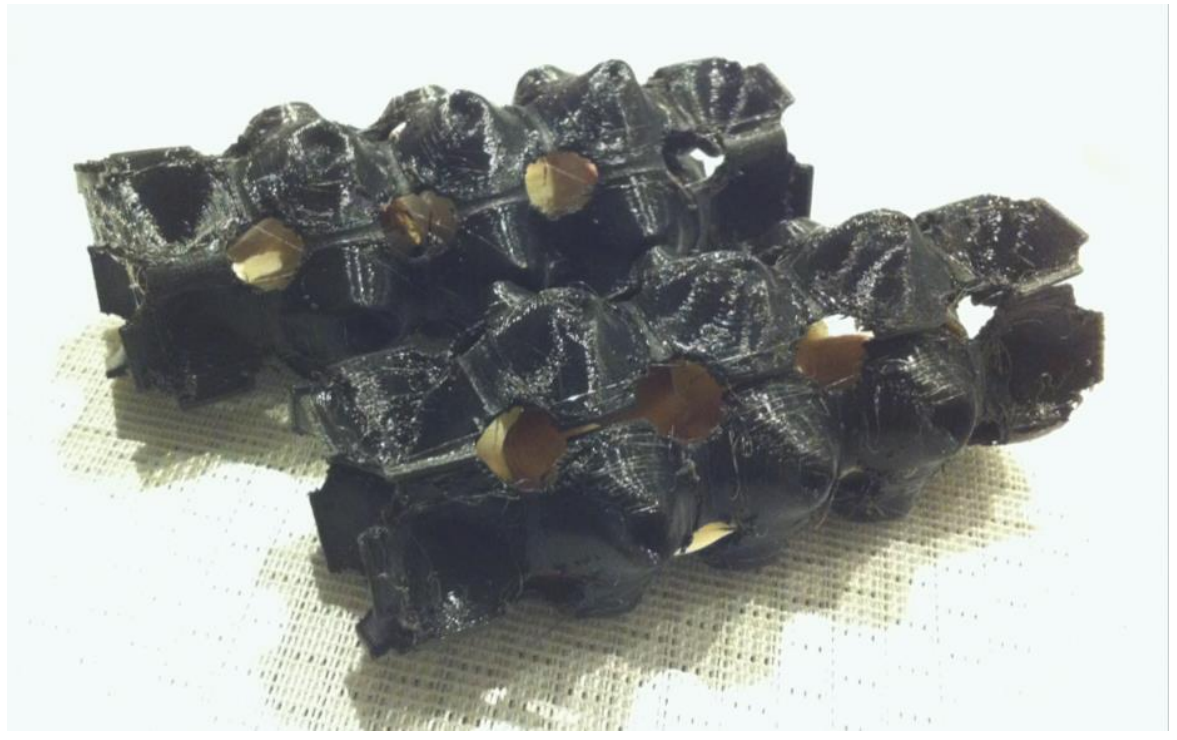

Figura 118 - Protótipo "face simples" medindo 10x10 cm do conceito (h) embalando algumas vagens de amendoim (foto da autora).

A configuração cilíndrica da embalagem proposta tinha que ser fechada nas extremidades para que evitasse a saída dos amendoins da embalagem. Ao invés de criar-se uma espécie de tampa, pensou-se em continuar trabalhando com a inversão dos cones. Dessa forma, o fechamento das extremidades estaria integrado à placa, sem necessidade do uso de novos elementos para fechamento da embalagem. Como pode-se verificar nas fotos abaixo, essa estratégica mostrou-se eficaz.

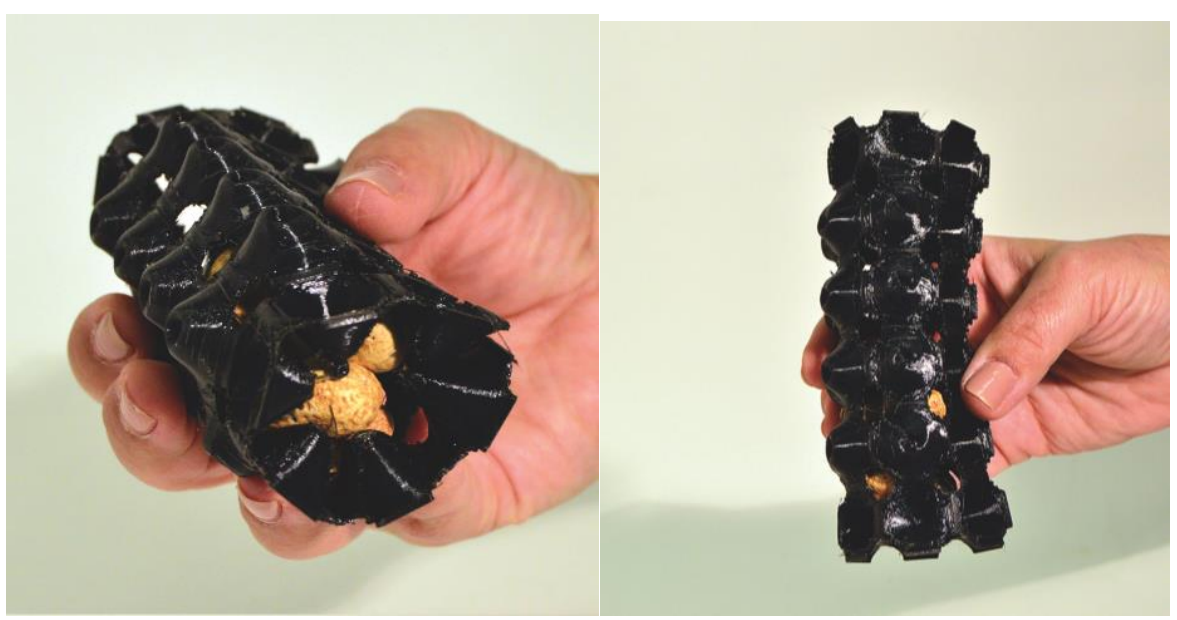

Figura 119 - Detalhe das extremidades do protótipo (h) com cones invertidos, criando uma espécie de fechamento nas extremidades do cilindro e evitando que amendoins caíssem (fotos da autora). 


\subsection{7 \\ Etapa B7: Explorar e validar o conceito de design mais promissor para inovação de embalagem bioinspirada}

Os resultados promissores e surpreendentes obtidos com o conceito (h) encorajaram novas explorações conceituais e de desenvolvimento técnico para concretização do objetivo geral pretendido nessa pesquisa: desenvolver soluções conceituais inovadoras para embalagens de alimentos, a partir da biomimética, apoiada por novas tecnologias digitais (microtomografia e impressão 3D).

Primeiramente explorou-se diferentes escalas de cones a fim de verificar o funcionamento da tensão mecânica experimentada no conceito (h) e que mostrouse essencial para a solução de embalagem pretendida na medida que potencializava o uso da placa, permitindo flexibilidade e adaptação a diversos conteúdos a serem embalados.

Partiu-se de cones medindo $20 \times 20 \times 11 \mathrm{~mm}$ até $25 \times 25 \times 15 \mathrm{~mm}$. Um detalhe muito importante verificado foi à necessidade de manter uma espessura mínima nas diferentes escalas de cones. A espessura ideal provou-se ser $1 \mathrm{~mm}$. Diversas placas foram prototipadas como verifica-se na foto abaixo.
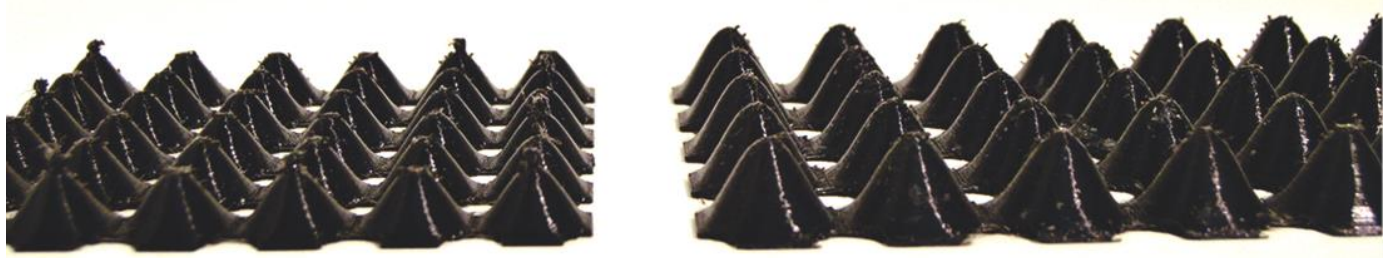

Figura 120 - Protótipos de placas com diferentes dimensionais de cones (fotos da autora).

Os cones maiores provaram -se tão eficazes quanto os menores e apresentaram um melhor acabamento quando invertidos. Esse fato influenciou a decisão de adotar o tamanho maior como padrão.

Modelou-se uma placa maior, medindo 150 x $200 \mathrm{~mm}$, com cones 25 x 25 x $15 \mathrm{~mm}$ e espessura de $1 \mathrm{~mm}$, que passaremos a identificar como Placa A. Desenho técnico dessa especificação, abaixo. 

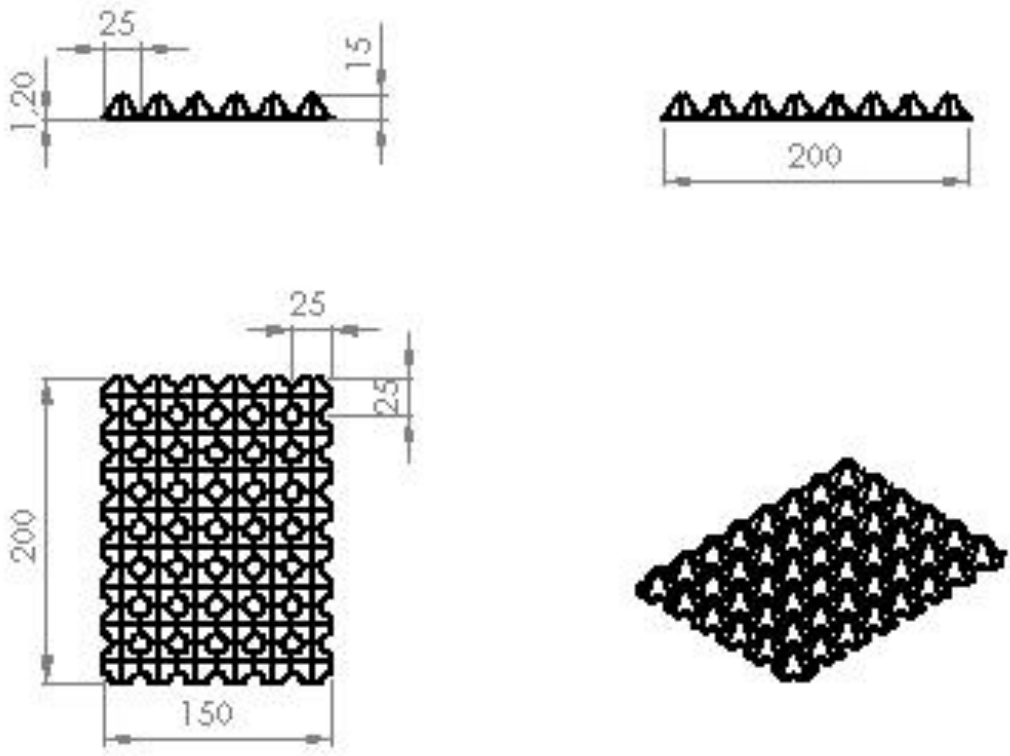

Figura 121 - Desenho técnico e especificações da Placa A.

Diversas placas (modelo Placa A) foram impressas na Markerbot e na Felix, usando filamento NinjaFlex, com o objetivo de experimentá-las embalando diversos alimentos, a fim de testar sua capacidade de acomodar e proteger os produtos.

A possibilidade de inversão dos cones, gerando modificação do plano por tensão mecânica, propiciou a experimentação de diferentes configurações formais para embalar o mesmo conteúdo.

Apresenta-se a seguir vários testes executados com a Placa $\mathrm{A}$ e validações de embalagem para diversos alimentos, entre eles: ovos, bananas e tomates. 

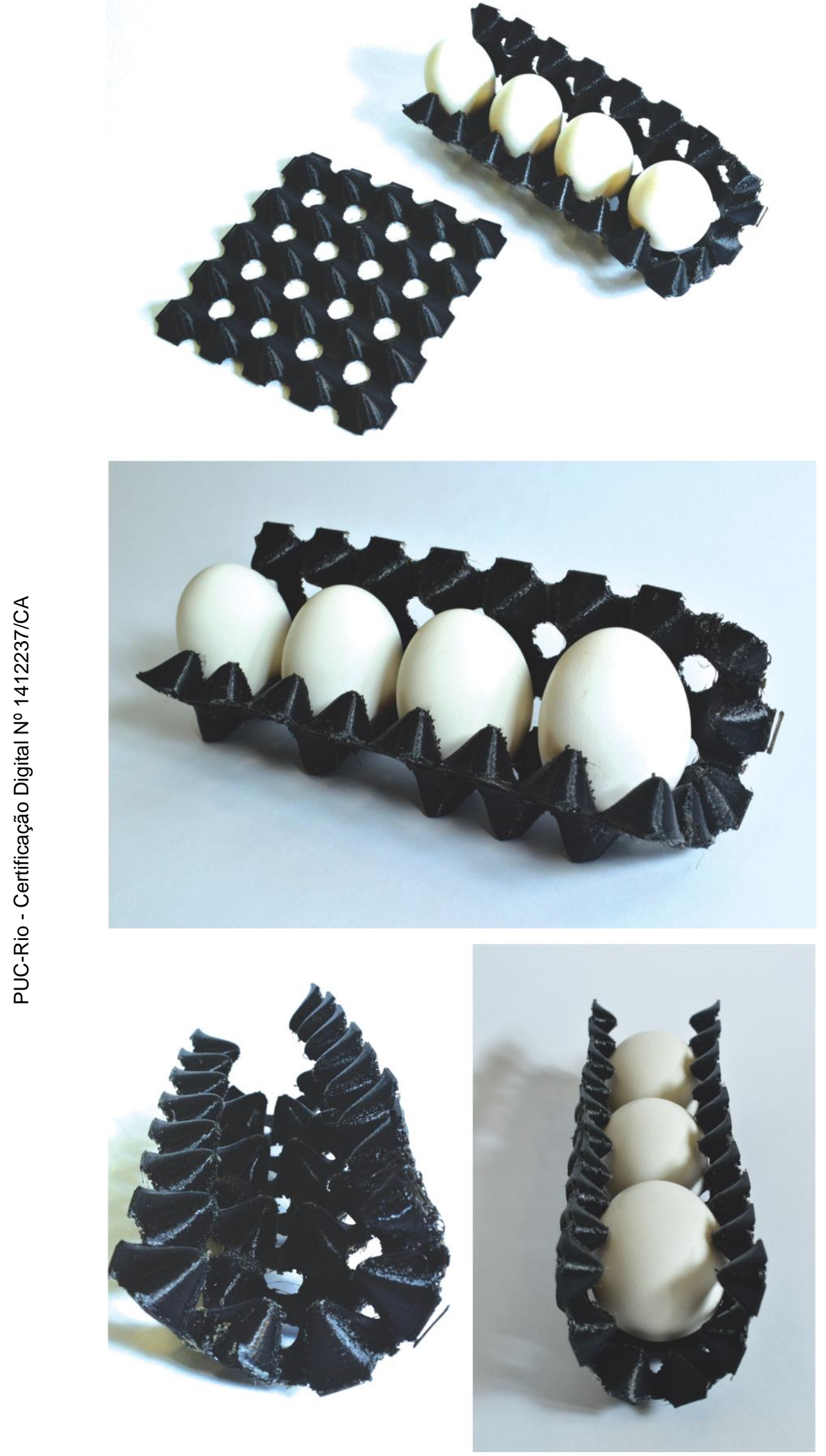

Figura 122 - Placa A, sendo testada na configuração 1 para ovos (fotos da autora). 

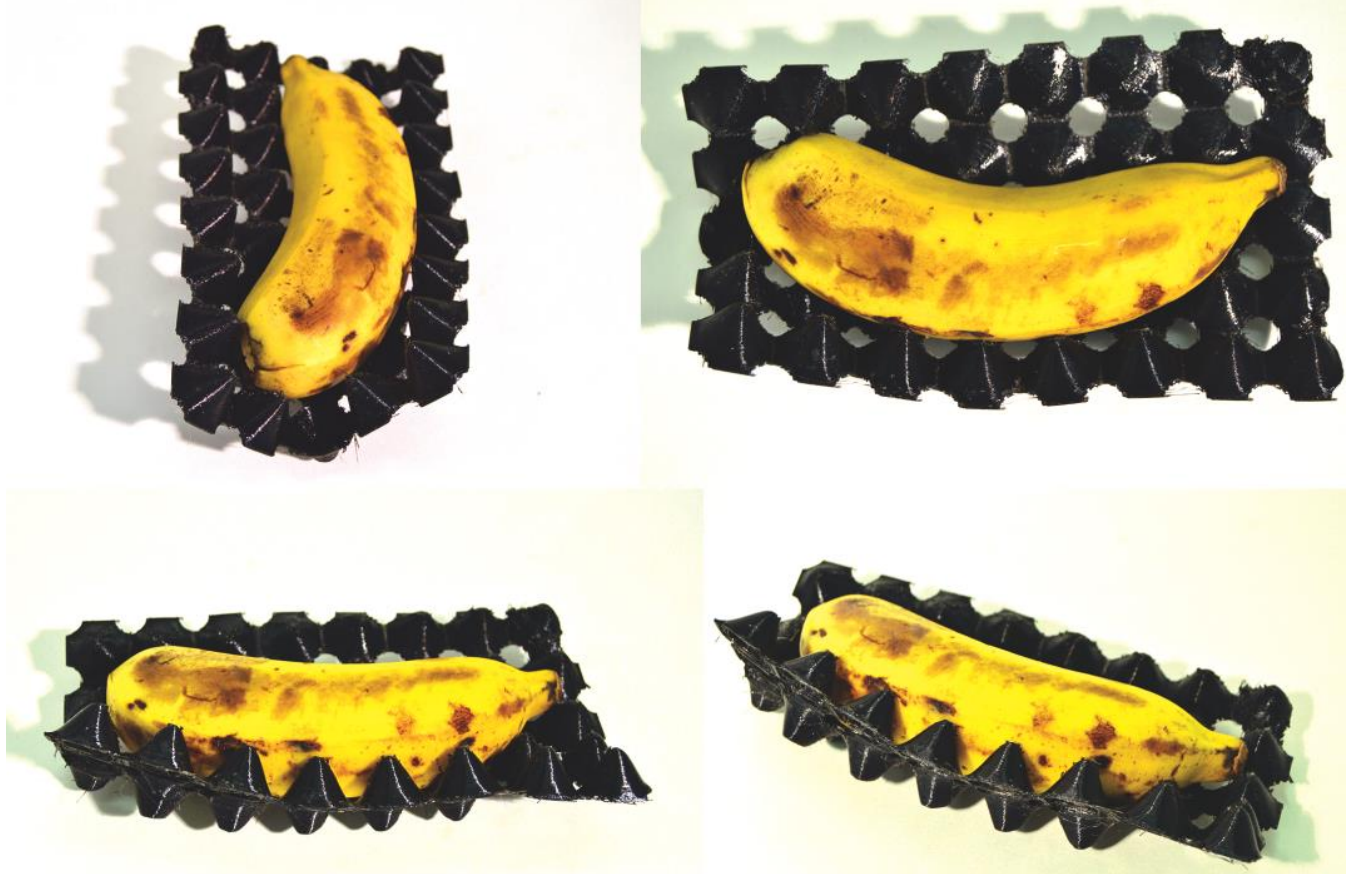

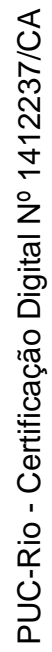
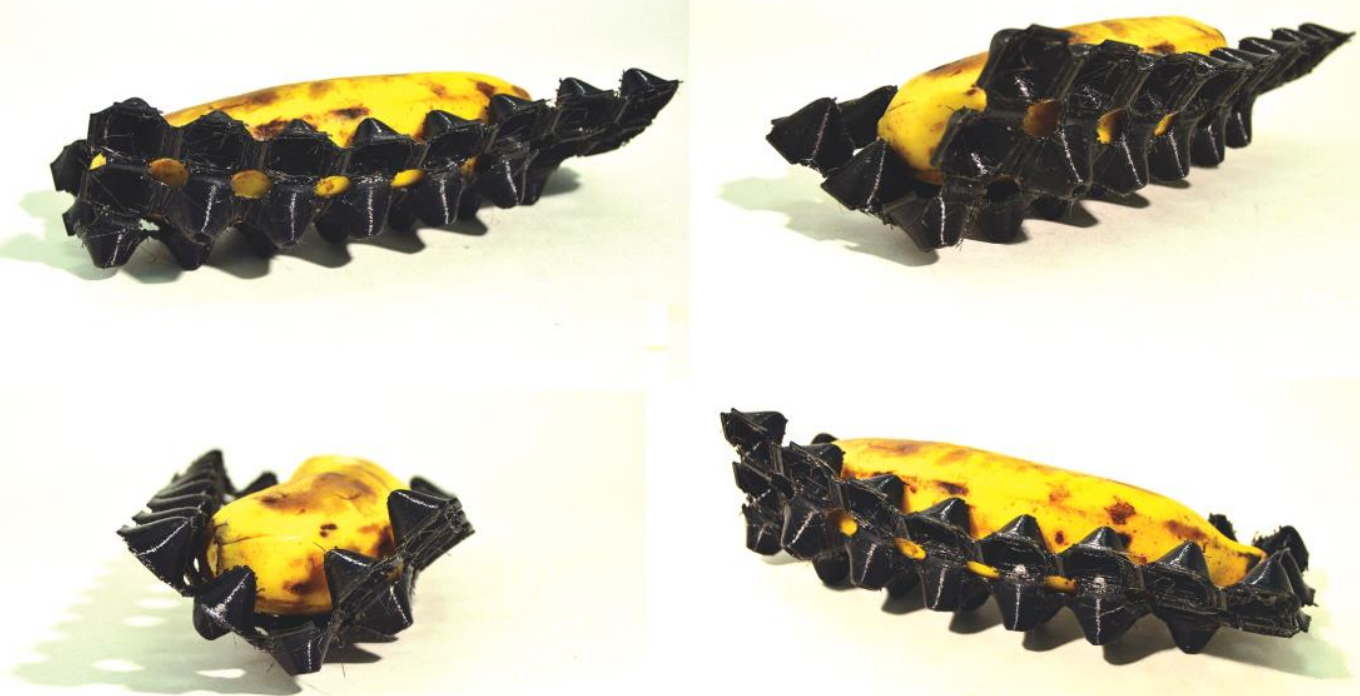

Figura 123- Placa A, sendo testada com banana (foto da autora). 

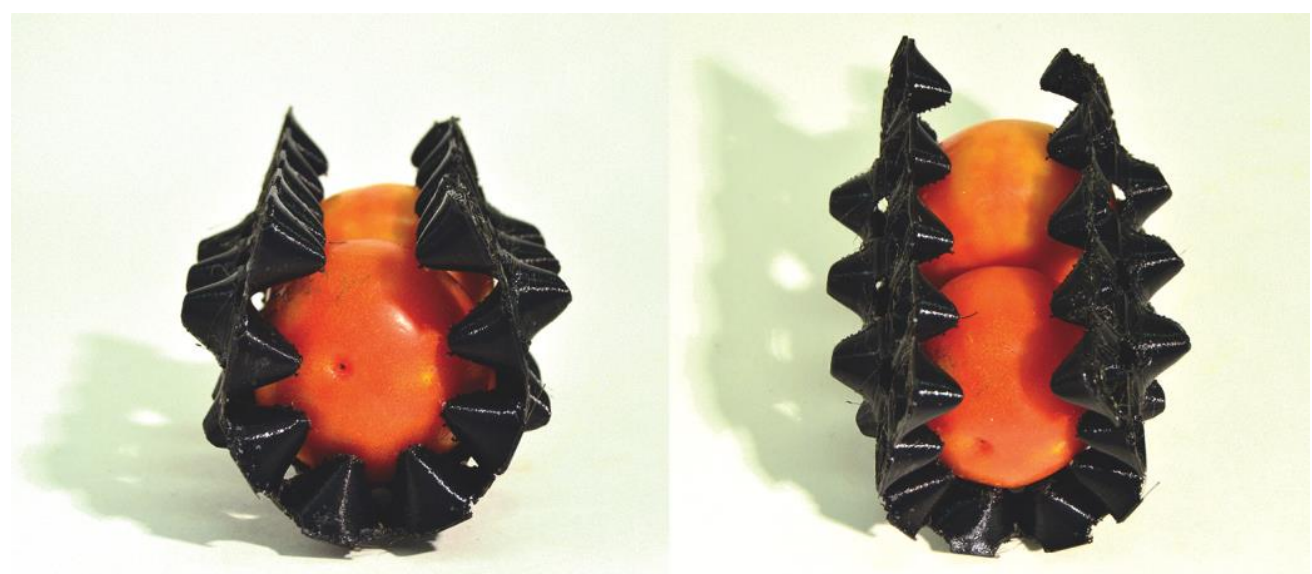

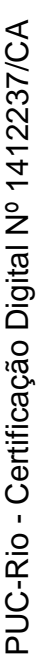
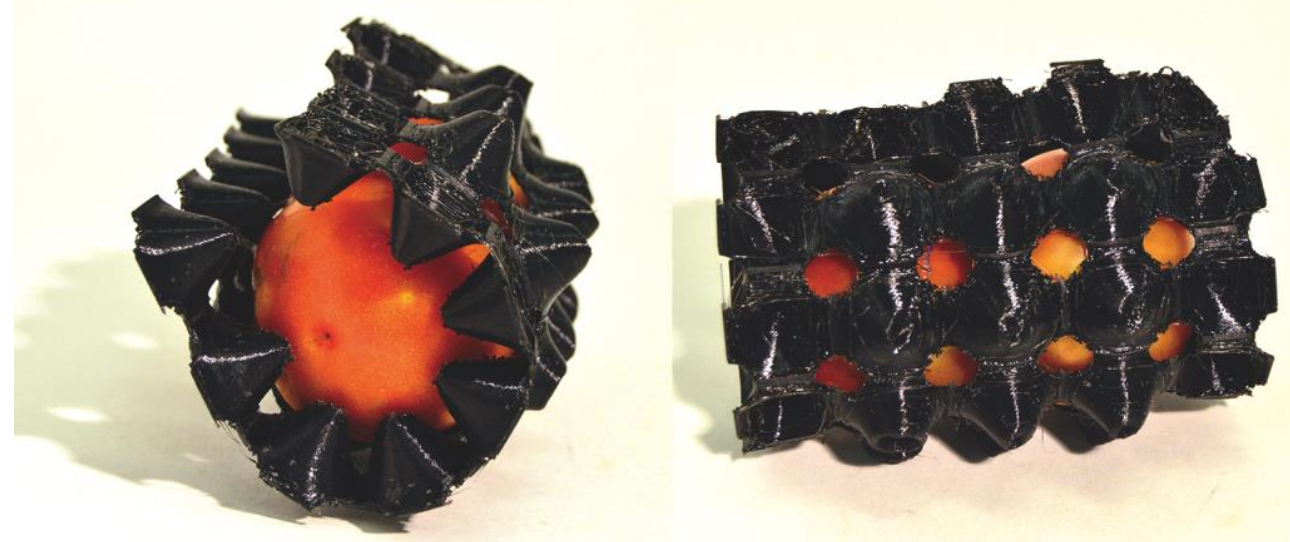

Figura 124 - Placa A, sendo testada na Configuração 1 com tomates (foto da autora).
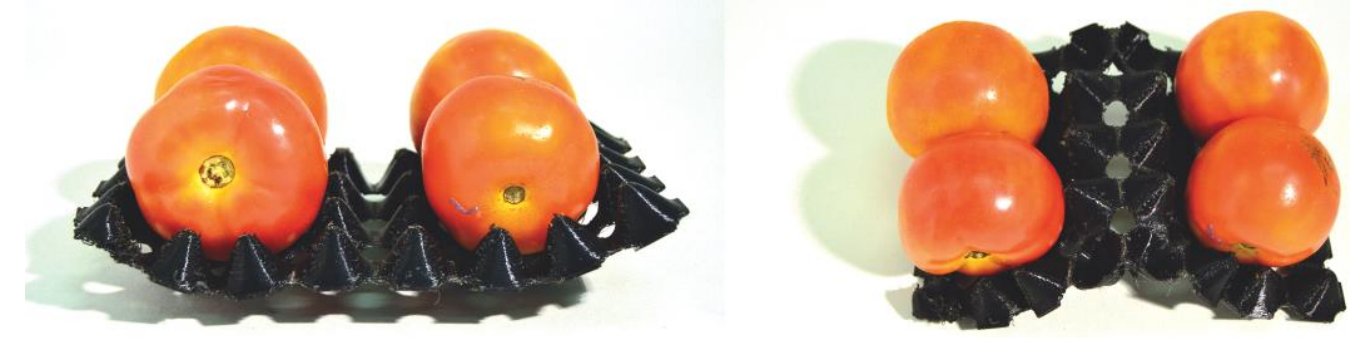

Figura 125 - Placa A, sendo testada na Configuração 2 com tomates (foto da autora).

Após testes de acomodação e proteção de alimentos bem sucedidos com os protótipos da Placa A, partiu-se para novas explorações do conceito (h), variandose a disposição dos cones e furações.

$\mathrm{Na}$ variação apresentada abaixo, os furos entre cones foram eliminados. A transformação do plano por tensão mecânica continuou funcionando. 

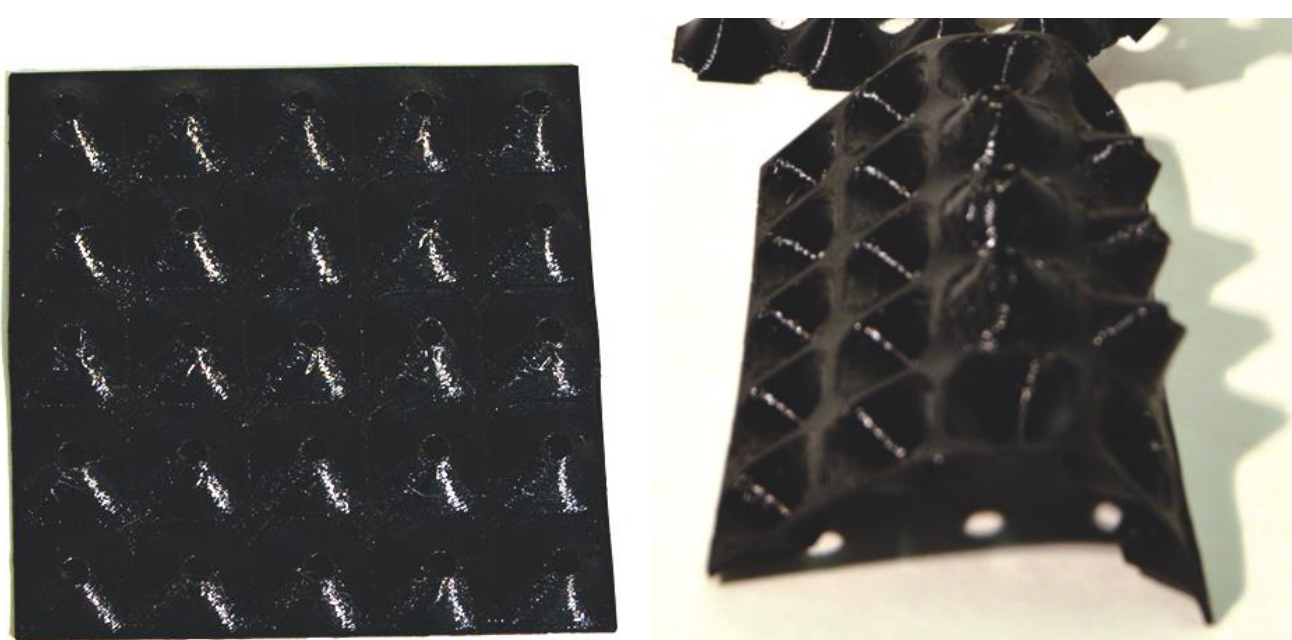

Figura 126 - Placa sem furos entre os cones e a deformação do plano causada pela tensão mecânica (foto da autora).

Essa variação pode ser aplicada quando o produto deve ser minimamente exposto ao tempo. $\mathrm{Na}$ foto (a) abaixo verifica-se maior proteção ao produto, do que na foto (b)

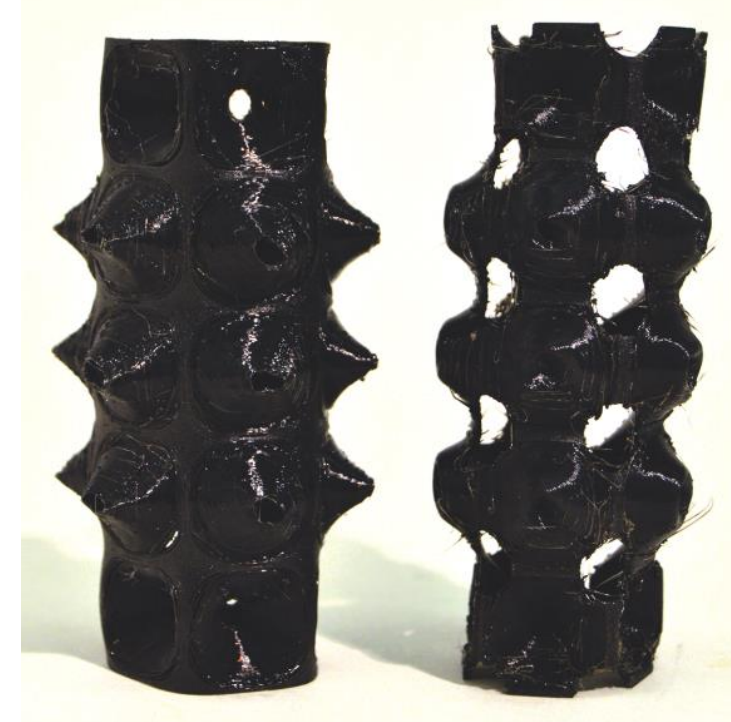

(a)

(b)

Figura 127 - Comparativo entre placa sem furos e com furos entre os cones (foto da autora).

Outra exploração feita foi o desalinhamento dos cones. Nessa variação aumenta-se a quantidade de material por placa, porém permite-se deformações do plano em direções diagonais. Foram testadas placas com e sem furos, como podese verificar nas modelagens 3D abaixo. 


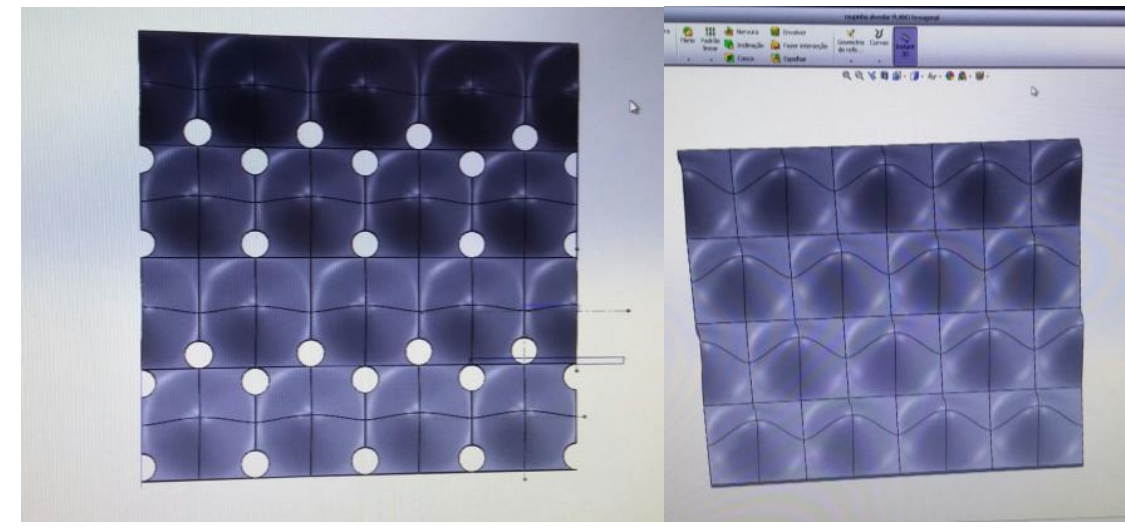

(a)

(b)

Figura 128 - Modelagens digitais com desalinhamento de cones: com furos (a) e sem furos (b) (fotos da autora).

Por fim, procurou-se explorar as diferentes configurações formais obtidas pela tensão mecânica provocada pela inversão dos cones. Observou-se que a inversão de conjuntos diferentes de cones ao longo da placa, resultavam em formas também diferentes e que a quantidade de variações possíveis era muito grande.

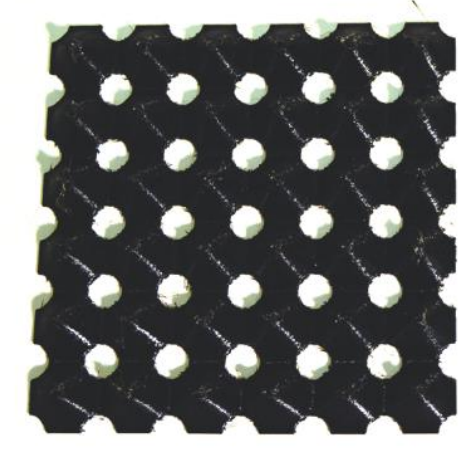

Figura 129 - Placa 10 x $10 \mathrm{~cm}$ antes da inversão de cones 


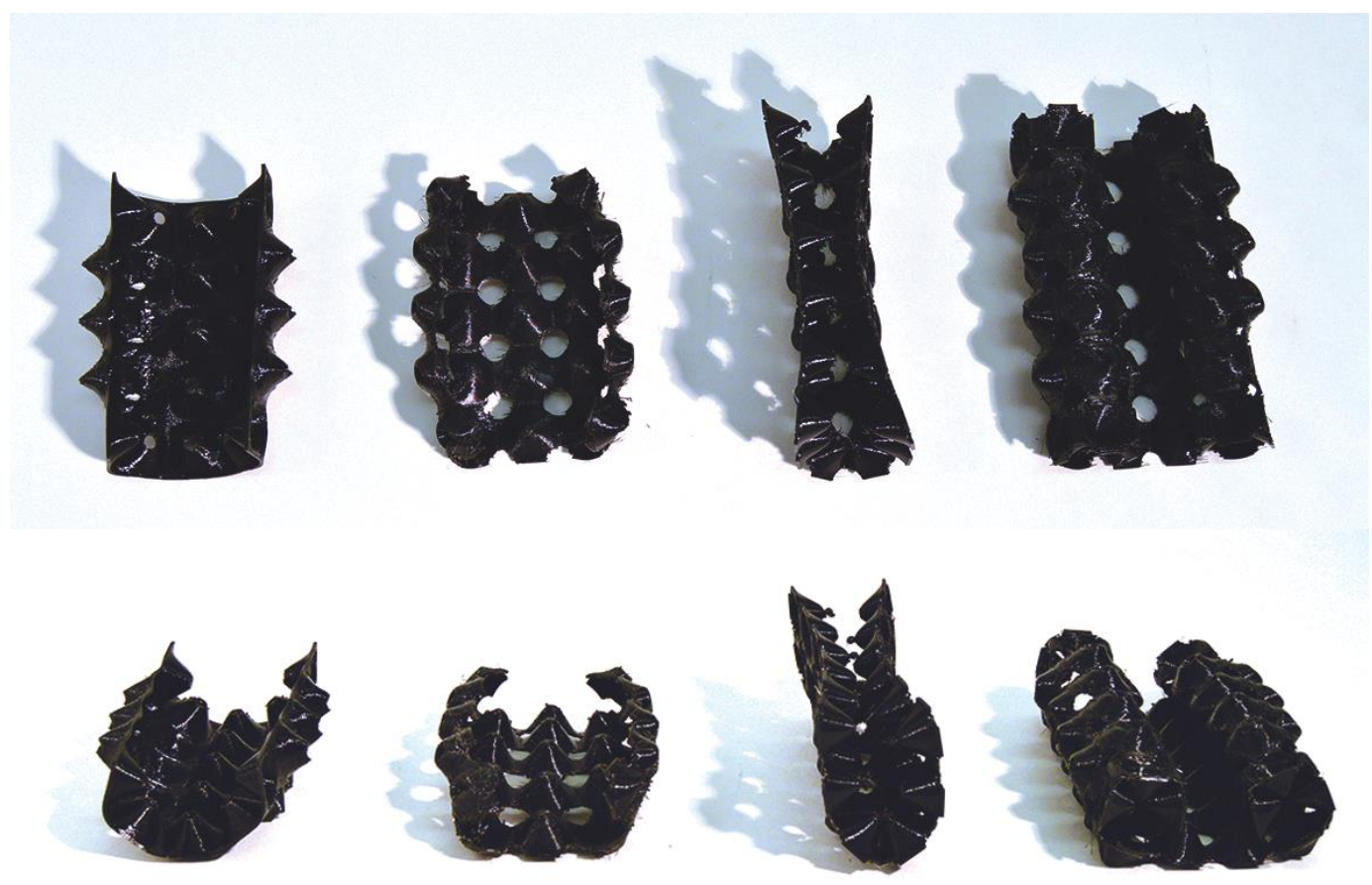

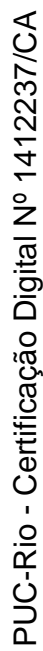

Figura 130 - Placa plana e as diversas transformações do plano obtidas (fotos da autora).
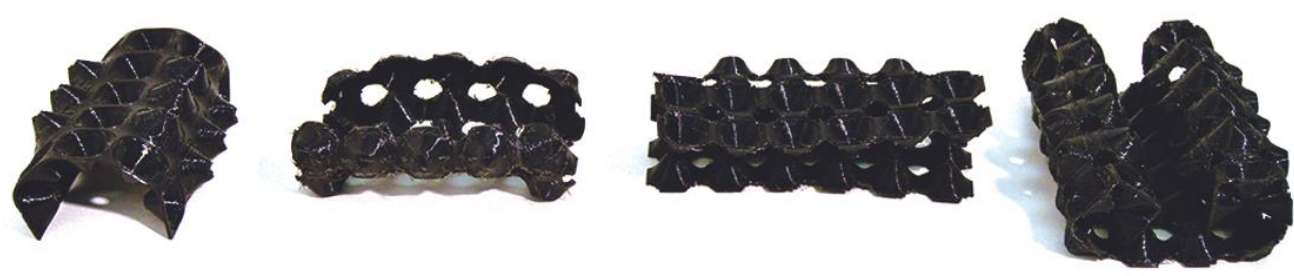

Figura 131 - Outra visão das diversas transformações do plano obtidas (fotos da autora). 

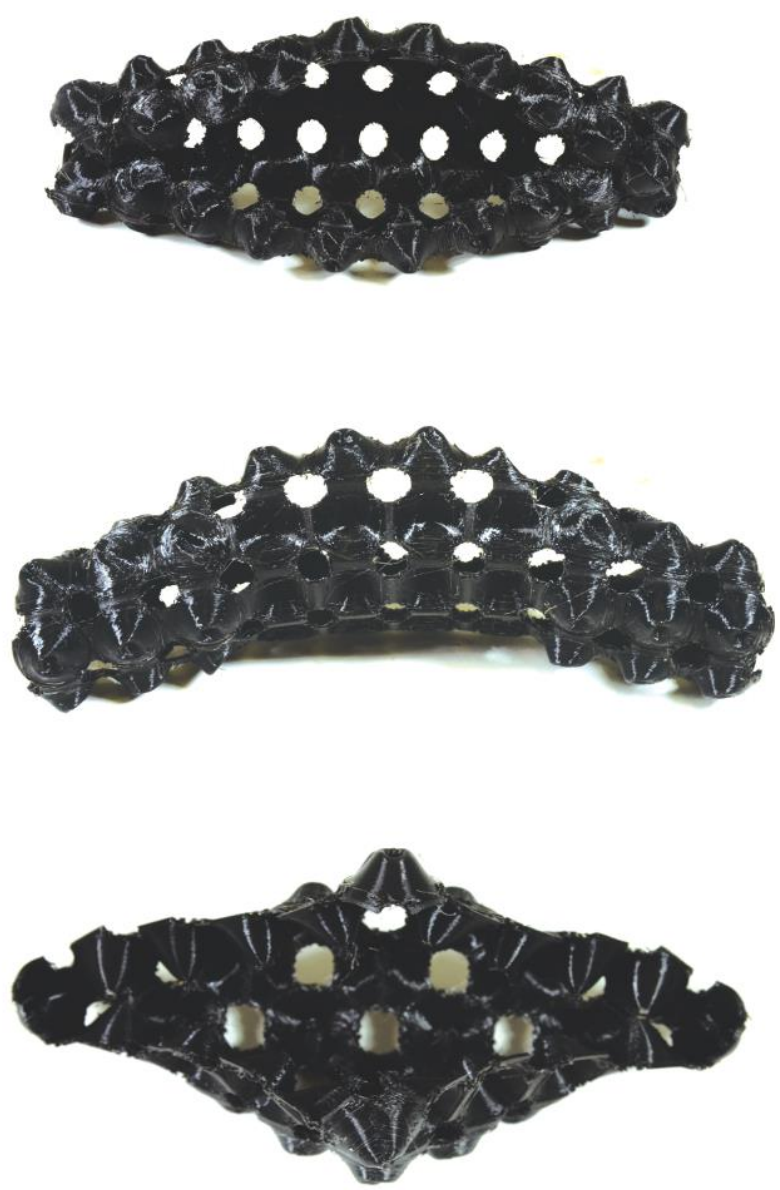

Figura 132 - Três configurações formais diferentes obtidas com o mesmo plano a partir de pressão alternada dos alvéolos (fotos da autora).

\section{3.}

\section{Conclusão do Experimento B}

O Experimento B caracterizou-se pelo intenso uso de novas tecnologias digitais, como microtomógrafo e impressora 3D. Usou-se como base metodológica o pensamento Biomimético - Biologia para Projetar (Biomimicry 3.8, 2007), porém, diferentemente da metodologia usada pelo Biomimicry 3.8, não integrou-se princípios da vida à solução, ou seja, não fez-se a avaliação das ideias bioinspiradas usando os princípios da vida como um checklist. Também executou-se uma etapa de validação do conceito de design mais promissor para inovação de embalagem bioinspirada.

Como a Experimentação B foi realizada a partir do mesmo organismo inspirador (o fruto do amendoim), portanto, não foi necessário repetir as Etapas de descoberta de modelos naturais e seleção do organismo inspirador. A Experimentação B, portanto, abrangeu as seguintes Etapas: Abstrair estratégias 
biológicas (B1); Identificar função e definir contexto (B2); Brainstorm 1 primeiras ideias bioinspiradas (B3); Emular conceitos de design do brainstorm 1 (B4); Brainstorm 2 - novas ideias bioinspiradas (B5); Emular conceitos de design do brainstorm 2 (B6); Explorar e validar o conceito de design mais promissor para inovação de embalagem bioinspirada (B7).

Constatou-se que as novas tecnologias digitais (utilizadas no Experimento B) de aquisição de imagem por meio de microtomografia (software Scout and Scan Control System), reconstrução da imagem (software XM Reconstructor Cobe Beam 10), tratamento dessas imagens digitalmente (softwares Fiji e Geomagic), permitiram uma investigação não invasiva, não destrutiva, detalhada, reveladora, precisa e acurada da vagem do amendoim, ampliando nossa visão e conhecimento por meio da aquisição de dados, colaborando, enfim, para o refinamento das abstrações de estratégias biológicas realizadas no Experimento A, e para a geração de ideias (Brainstorm) do Experimento B. É importante frisar o uso inovador do equipamento de microtomografia (uma espécie de radiografia em 3D) na aquisição de imagens de materiais biológicos.

Os principais refinamentos relacionaram-se à constatação (que não foi possível a "olho nú"), da presença de alvéolos e de duas fendas longitudinais na casca da vagem. Abstraídas e refinadas as estratégias (por meio das novas tecnologias digitais) e definidas as funções do fruto do amendoim, geraram-se ideias para embalagens, desta vez percebeu-se um incremento na quantidade de associações e na qualidade e variedade das analogias, que extrapolaram os aspectos formais superficiais do fruto do amendoim, demonstrado que o pensamento criativo lateral foi estimulado pelas imagens adquiridas com as novas tecnologias.

Também utilizou-se no Experimento B, novas tecnologias digitais de modelagem tridimensional (softwares Rhinoceros e Solidworks), prototipagem rápida em impressoras 3D (CubePro, Felix e MakerBot), que possibilitaram a materialização rápida de protótipos em diversas configurações e materiais, permitindo a exploração de diversos conceitos de design e a validação do mais promissor para inovação de embalagem bioinspirada. 


\section{5.}

\section{Conclusão}

A embalagem está no centro de questões de sobrevivência alimentar para mais de sete bilhões de pessoas hoje no mundo. A Organização Mundial da Embalagem (WPO), afirma que a embalagem é uma ferramenta que viabiliza a sociedade atual e que deve estar aliada à preservação da vida, da saúde e dos recursos naturais, e que seu avanço tecnológico deve ser guiado pela busca de melhor qualidade de vida para mais pessoas. (WPO, 2011).

A importância de soluções inovadoras e sustentáveis para problemas globais, como a fome, impõem à indústria, empresas, governo e consumidores, uma mudança de estratégia, de comportamento e de modelo mental, trazendo novos paradigmas baseados no pensamento híbrido (material e digital), sistêmico, tecnológico, criativo, interdisciplinar, com foco no humano e no olhar para a natureza, não só como recurso, mas também como inspiração.

Por outro lado, as novas tecnologias digitais estão provocando mudanças sísmicas nas economias mundiais. Elas oferecem uma nova forma de aproximação e abordagem para lidar com a complexidade dos dias atuais, pois permitem comunicação ágil em rede, visualização e análise de dados, mudança de modelo fabril e de manufatura, entre outros. (MIT Technology Review, 2015).

A presente pesquisa teve uma característica exploratória, voltada a investigar se abordagens de pensar e projetar embalagens por meio de analogias entre biologia e design (Biomimética) são potencializadas por novas tecnologias digitais (especialmente microtomografia e impressão 3D). E também, uma característica experimental, objetivando estimular a criação e materialização de conceitos inovadores Biomiméticos, para embalagem de alimentos.

A investigação esclareceu que o processo cognitivo envolvido na formação de analogias é importante para melhorar o processo de "Design Biomimético". Os psicólogos americanos Gentner e Markman descobriram que o processo de formação de analogias é baseado principalmente em observação, associações, compara- 
ções, correspondências, semelhanças, similitudes, memória e combinação de conceitos que em princípio não estavam relacionados, gerando assim, soluções, ideias originais e inovações. Em sua pesquisa Structure Mapping in Analogy and Similarity, os pesquisadores explicam que o processo começa quando uma pessoa aprende um novo conhecimento e codifica a Fonte de inspiração para um problema futuro. Em algum momento do futuro, a pessoa se depara com um novo problema e deve recuperar (lembrar-se), de uma Fonte adequada de ideia para resolver o novo problema. Ao desenvolvermos esses mapeamentos, criamos novas inferências (soluções). (Gentner e Markman, 1997).

Segundo Baxter (1998, p. 116) "analogia é uma espécie de raciocínio, em que propriedades de um objeto são transferidas para outro objeto diferente, mas com certas propriedades em comum”. Em seu livro "Projeto de Produto", 1998, ele esclarece que analogias são usadas para estimular o pensamento lateral (bissociação), e a capacidade de fazer novas associações, a fim de ultrapassar as ideias mais óbvias. Podem criar soluções completamente novas, descobrindo-se como um problema semelhante é resolvido em contexto diferente.

Esse processo de analogias promove novas influências e permite interpretar problemas de novas maneiras, mais inovadoras e perspicazes. Ainda segundo a pesquisa acima, o potencial para resolução criativa de problemas é mais perceptível, quando os domínios comparados são muitos diferentes na superfície e em campos de conhecimento distantes um do outro.

Um panorama diversificado de soluções disponíveis na natureza podem lançar-nos à criação de produtos mais inteligentes, por meio da Biomimética, no entanto, existem muitas lacunas entre os princípios que podem ser encontrados na natureza e as soluções de design aplicadas. Como garantir e integrar os princípios Sustentáveis através da Biomimética? Essa certamente é uma questão que necessitará um aprofundamento em futuras pesquisas.

Além disso, no campo das novas tecnologias, qual o papel, os limites e os recursos disponíveis para que o designer possa "apropriar-se" deste potencial disponível na natureza?

As metodologias investigadas nessa dissertação para o processo de Design Biomimético podem ser usadas para resolver problemas complexos por pesquisadores de diversas áreas, desde design, engenharia até inteligência artificial (AI). Elas apoiam e estimulam analogias biológicas e sistematizam a transferência de 
informação e significado de um sujeito particular (fonte: natureza), para outro sujeito particular (alvo: produtos e serviços). Ao utilizá-las o designer pode adquirir uma ampla gama de possibilidades inventivas e estratégias, pois aproxima conhecimentos interdisciplinares, que em princípio não estavam relacionados, como biologia e design, e isso gera maior possibilidade de soluções originais que estabelecem novos paradigmas para resolver problemas e desafios enfrentados pelo homem.

O método escolhido para as Experimentação é baseado na abordagem metodológica Biomimicry Design Lens (Lentes Biomiméticas), especialmente o modelo Biology to design (Biologia para Projetar) do Biomimicry 3.8 (2013). Cabe destacar que a experimentação foi estruturada em dois momentos; visando avaliar a influência do uso de novas tecnologias digitais: Experimentação A (sem uso de novas tecnologias digitais), e Experimentação B (com uso de novas tecnologias digitais).

A Experimentação A abrangeu as seguintes Etapas: Descobrir modelos naturais (A1); Selecionar organismo inspirador (A2); Abstrair estratégias biológicas (A3); Identificar função e definir contexto (A4); Brainstorm ideias bioinspiradas (A5). Foi realizada a partir do pensamento Biomimético, Biologia para Projetar (Biomimicry 3.8, 2007), porém, diferentemente da metodologia usada pelo Biomimicry 3.8, não integrou-se princípios da vida à solução, ou seja não fez-se a avaliação das ideias bioinspiradas usando os princípios da vida como um chekcklist, nem tampouco avançou-se nas Etapas posteriores ao Brainstorm, o que a autora avalia ser necessário futuramente para uma análise comparativa mais aprofundada sobre os resultados com uso, ou não, das novas tecnologias digitais, pois, no Experimento A, não foram utilizadas novas tecnologias digitais, como microtomógrafo e impressora 3D, e o Experimento B fez uso intenso dessas tecnologias.

Constatou-se que foi fundamental o apoio do biólogo em visitas ao Jardim Botânico e na orientação teórica sobre o Reino da Plantas (Angiospermas), durante a Etapa A1 (descobrir um organismo ou ecosistema inspirador, e aprender sobre suas estratégias para evoluir e sobreviver). As bases de dados virtuais abriram um amplo campo de conhecimento, porém são difícies de consultar, por esse motivo privilegiou-se o contato direto com o biólogo. 
A escolha do fruto do amendoim como organismo inspirador, mostrou-se acertada, pois as abstrações de suas estratégias biológicas geraram insights sobre as funções e o contexto onde as mesmas são desejadas, no caso dessa pesquisa, o design de embalagem.

É importante ressaltar que nesse experimento não houve o apoio das novas tecnologias digitais, portanto, foi muito importante a experiência da autora como designer para, a olho "nú", realizar uma análise morfológica e abstratir as estratégias do organismo e posteriormente entender as "coisas" que a estratégia faz para o organismo, e o contexto onde essa função é desejada. Abstraídas as estratégias e definidas as funções do fruto do amendoim, geraram-se ideias para embalagens, porém com analogias muito próximas aos aspectos formais e estruturais, perceptíveis à "olho nú", do fruto do amendoim.

O Experimento B caracterizou-se pelo intenso uso de novas tecnologias digitais, como microtomógrafo e impressora 3D. Usou-se como base metodológica o pensamento Biomimético - Biologia para Projetar (Biomimicry 3.8, 2007), porém, diferentemente da metodologia usada pelo Biomimicry 3.8, não integrou-se princípios da vida à solução, ou seja, não fez-se a avaliação das ideias bioinspiradas usando os princípios da vida como um checklist. Também executou-se uma etapa de validação do conceito de design mais promissor para inovação de embalagem bioinspirada.

Como a Experimentação B foi realizada a partir do mesmo organismo inspirador (o fruto do amendoim), portanto, não foi necessário repetir as Etapas de descoberta de modelos naturais e seleção do organismo inspirador. A Experimentação B, portanto, abrangeu as seguintes Etapas: Abstrair estratégias biológicas (B1); Identificar função e definir contexto (B2); Brainstorm 1 primeiras ideias bioinspiradas (B3); Emular conceitos de design do brainstorm 1 (B4); Brainstorm 2 - novas ideias bioinspiradas (B5); Emular conceitos de design do brainstorm 2 (B6); Explorar e validar o conceito de design mais promissor para inovação de embalagem bioinspirada (B7).

Constatou-se que as novas tecnologias digitais (utilizadas no Experimento B) de aquisição de imagem por meio de microtomografia (software Scout and Scan Control System), reconstrução da imagem (software XM Reconstructor Cobe Beam 10), tratamento dessas imagens digitalmente (softwares Fiji e Geomagic), permitiram uma investigação não invasiva, não destrutiva, detalhada, reveladora, 
precisa e acurada da vagem do amendoim, ampliando nossa visão e conhecimento por meio da aquisição de dados, colaborando, enfim, para o refinamento das abstrações de estratégias biológicas realizadas no Experimento A, e para a geração de ideias (Brainstorm) do Experimento B. É importante frisar o uso inovador do equipamento de microtomografia (uma espécie de radiografia em 3D) na aquisição de imagens de materiais biológicos.

Os principais refinamentos relacionaram-se à constatação (que não foi possível a "olho nú"), da presença de alvéolos e de duas fendas longitudinais na casca da vagem. Abstraídas e refinadas as estratégias (por meio das novas tecnologias digitais) e definidas as funções do fruto do amendoim, geraram-se ideias para embalagens, desta vez percebeu-se um incremento na quantidade de associações e na qualidade e variedade das analogias, que extrapolaram os aspectos meramente formais do organismo, demonstrado que o pensamento criativo lateral foi estimulado pelas imagens adquiridas com as novas tecnologias.

Também utilizou-se no Experimento B, novas tecnologias digitais de modelagem tridimensional (softwares Rhinoceros e Solidworks), prototipagem rápida em impressoras 3D (CubePro, Felix e MakerBot), que possibilitaram a materialização rápida de protótipos em diversas configurações e materiais, permitindo a exploração de diversos conceitos de design e a validação do mais promissor para inovação de embalagem bioinspirada.

Ao final, graças ao processo de design exploratório e experimental, chegamos a um conceito de design, que foi resultado de um desdobramento das analogias geradas entre biologia (vagem do amendoim) e design (embalagens). Ele propõe um sistema inovador para embalagens de alimentos que: aumenta a proteção e conservação, reduzindo o desperdício, permite adaptação a diferentes formatos e dimensões do conteúdo a ser embalado, e otimiza o uso de materiais e processos.

O resultado final alcançado faz-nos vislumbrar uma série de ampliações desta pesquisa, principalmente ao que se refere à viabilidade técnica e implementação industrial do sistema criado, a fim de que seu uso possa ser generalizado em larga escala e, desta forma, contribuir para gerar impacto positivo nas questões contemporâneas de acesso e preservação de alimentos. 


\section{6. \\ Referências Bibliográficas}

AGAREZ, Fernando Vieira. Botânica: taxonomia, morfologia e reprodução dos angiospermae: chave para determinação das famílias. Rio de Janeiro: Âmbito Cultural Edições Ltda, 1994.

ASHOK, Goel. Analogical Reasoning, Biologically Inspired Design. USA: C. Eckert \& P. Vermaas, 2014

BAXTER, Mike. Projeto de Produto. São Paulo: Ed. Blucher, 2010.

BENYUS, Janine. Biomimética: inovação inspirada pela natureza. São Paulo: Ed. Pensamento-Cultrix, 2003.

BENYUS, Janine, BAUMEISTER, Dayna. Packaging Tips from the Porcupine Fish. USA: Biomimicry Institute, 2002.

BHATTA, SAMBASIVA R.; GOEL, ASHOK K. Creative Analogies in Biologically Inspired Design. Reino Unido: Cambridge Journal, p. 131-136, 1996.

BIOMIMICRY 3.8. Biomimicry Design Lens. Licenced under creative commons BY-NC-ND. Disponível em: http://biomimicry.net/about/biomimicry/biomimicrydesignlens>. Acesso em: 21 nov. 2014.

CARDOSO, Rafael. Design para um mundo complexo. São Paulo: Cosac Naify, 2012.

CARSON, Shelley. O cérebro criativo. São Paulo: Best Seller, 2012.

CHAKRABARTI, A., SARKAR, P., LEELAVATHAMMA, B. and NATARAJU, B. A functional representation for aiding biomimetic and artificial inspiration of new ideas. Cambridge: Artificial Intelligence for Engineering Design, Analysis and Manufacturing, vol. 19, no. 2, pp. 113-132, (2005)

EMTECH BRASIL 2015. Viver em uma Cidade Inteligente, hoje. Rio de Janeiro: MIT Technology Review, 2015.

GENTNER, Dedre; MARKMAN, Arthur B. Structure Mapping in Analogy and Similarity. USA: American Psychological Association, 1997.

GORDON, William J.J. Synectics: The Development of Creative Capacity. New York: Harper \& Brothers, 1961. 
HEY et al. Analogies and Metaphors in Creative Design, International Journal of Engineering Education, 2008, Volume 24, Número 2

HELMS, Michael, VATTAM, Swaroop S. and GOEL, Ashok. Biologically inspired design: process and products. USA: Design Studies, 30(5), 606-622, 2009

HELMS, Michael, VATTAM, Swaroop S. and GOEL. A content account of creative analogies in biologically inspired design. Artificial Intelligence for Engineering Design, Analysis and Manufacturing. London: Cambridge University Press, 2010 24, pp 467-481 doi:10.1017/ S089006041000034X - Elsevier

HINE, Thomas. The Total Package. The evolution and secret meanings of boxes, bottles, cans and tubes. Boston: Little, Brown and Company, 1995

HORNORG, Alf et al. Ecology and Power: Struggles over Land and Material Resources in the Past, Present, and Future. Routledge, 2012.

JOHNSON, Michael. "Problem solved". London: Phaidon, 2012.

JUNG, Rex et al. Neuroanatomy of creativity. USA: Hum. Brain Mapp. 31, 398409, 2010.

LOPES, Jorge; BRANCAGLION, Antonio Jr; AZEVEDO, Sergio Alex; WERNER, Heron JR. Tecnologias 3D: desvendando o passado, modelando o futuro. Rio de Janeiro: Lexiton, 2013

MIRANDA, Márcio. Para ouvir os cientistas. O Globo, Rio de Janeiro, 2015. Disponível em http://oglobo.globo.com/opiniao/para-ouvir-os-cientistas-17988867 Acesso em: 7 de nov. 2015

NATIONAL ACADEMY OF ENGINEERING. Educate to Innovate: Factors That Influence Innovation: Based on Input from Innovators and Stakeholders. Washington, DC: The National Academies Press, 2015.

OLIVEIRA, Eurico Cabral de. Introdução à biologia vegetal. São Paulo: Editora da Universidade de São Paulo, 2008.

PAPANECK, Victor. Design for the real world. London: Paladin, 1973

ROBINSON, Ken. Libertando o Poder Criativo. São Paulo: HSM Editora, 2012.

SALGUEIREDO, Camila Freitas. Modeling inspiration for innovative NPD: lessons from biomimetics. Paris: 20th International Product Development Management Conference, 2013

SHU, L.H. et al. Biologically inspired design. Canadá: CIRP Annals - Manufacturing Technology 60 (673-693), 2011.

SPECK, T; SPECK, O. Process sequences in biomimetic research. Alemanha: WIT Transactions on Ecology and the Environment-Volume: 114, 2008. 
STEELE, J.E. Living prototypes-The key to new Technologies. Wright-Patterson Air Force Base, Ohio, Directorate of Advanced Systems Technology, Wright Air Development Division, Air Research and Development Command, U.S. Air Force, 1961.

VINCENT, Julian F. V. et al. Biomimetics: its practice and theory. London: J. R. Soc. Interface, 2006

WORLD PACKAGING ORGANIZATION (WPO). Packaging - An important tool for a sustainable society. USA: World Packaging Organization, 2011

\section{Homepages:}

ACTIVE WIREHEAD. Disponível em: http://www.activewirehead.com/bionicleg-hugh-herr>. Acesso em: 7 dez. 2015.

ASK NATURE - The Biomimicry 3.8 Institute, 2008-2016. Disponível em: <http://www.asknature.org>. Acesso em: 5 jan. 2014.

BIOMIMICRY 3.8. The Biomimicry design portal. The Biomimicry 3.8 Institute, 2008-2016. Disponível em: 〈http://www.biomimicry.org>. Acesso em: 5 jan. 2014.

BLOOMBERG THE COMPANY \& ITS PRODUCTS. Dipsonível em: http://www.bloomberg.com/slideshow/2013-08-18/14-smart-inventions-inspiredby-nature-biomimicry.html\#slide6site>. Acesso em: 21 maio 2015.

DESIGN INTELLIGENCE LAB DA SCHOOL OF INTERACTIVE COMPUTING \& THE CENTER FOR BIOLOGICALLY INSPIRED DESIGN. Disponível em: < http://www.cbid.gatech.edu>. Acesso em: 10 fev. 2014.

EMBALAGEM SUSTENTÁVEL . Disponível em: http://embalagemsustentavel.com.br/2009/11/14/embalagem-de-bacteria/. Acesso em: 7 dez.2015.

ENCYCLOPEDIA OF LIFE. Disponível em: <http://eol.org/>. Acesso em 5 março 2014.

FASTCO DESIGN. Disponível em: <http://www.fastcodesign.com/>. Acesso em 20 nov. 2014.

FOOD AND AGRICULTURE ORGANIZATION OF THE UNITED NATIONS. Disponível em: <http://www.fao.org>. Acesso em: 22 nov. 2014.

KOD*LAB. Disponível em: http://kodlab.seas.upenn.edu/. Acesso em 6 dez. 2015. 
MASSACHUSETTS INSTITUTE OF TECHNOLOGY. Disponível em:

<http://senseable.mit.edu>. Acesso em: 17 nov. 2015.

O GLOBO. Desenvolvido por Infoglobo Comunicação e Participações S.A, 19962016. Disponível em < http://oglobo.globo.com/sociedade/tecnologia/sensoresbig-data-revolucionam-gerenciamento-urbano-18080436>. Acesso em: 27 nov. 2014.

PLANTILLUSTRATIONS. Disponível em:

<http://www.plantillustrations.org/>.Acesso em 7 dez. 2015.

POLYPEDAL LAB. Disponível em: <http://polypedal.berkeley.edu/>. Acesso em 7 dez. 2015.

REX JUNG. Creativity. Disponível em: < http://www.rexjung.com/creativity>. Acesso em: 20 mar. 2015

WIRED. Disponível em: <http://www.wired.com/2013/03/biomimetic-materials/> Acesso em: 7 dez. 2015.

WORLD PACKAGING ORGANIZATION (WPO). Disponível em:

<http://www.worldpackaging.org>. Acesso em 30 abr. 2015.

WYSS INSTITUTE. Disponível em: < http://wyss.harvard.edu/viewpage/204/ bioinspired-robotics>. Acesso em 7 dez.2014. 